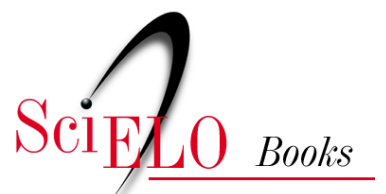

\title{
Saúde Indígena em perspectiva explorando suas matrizes históricas e ideológicas
}

\author{
Carla Costa Teixeira \\ Luiza Garnelo \\ (orgs.)
}

TEIXEIRA, CC., and GARNELO, L., comps. Saúde Indígena em perspectiva: explorando suas matrizes históricas e ideológicas [online]. Rio de Janeiro: Editora FIOCRUZ, 2014, 261 p. Saúde dos povos Indígenas collection. ISBN: 978-85-7541-582-5. https://doi.org/10.7476/9788575415825.

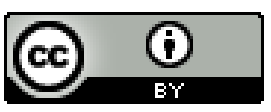

All the contents of this work, except where otherwise noted, is licensed under a Creative Commons Attribution 4.0 International license.

Todo o conteúdo deste trabalho, exceto quando houver ressalva, é publicado sob a licença Creative Commons Atribição 4.0. 
Saúde Indígena em Perspectiva: explorando suas matrizes históricas e ideológicas 


\title{
FUNDAÇÃO OSWALDO CRUZ
}

Presidente

Paulo Gadelha

Vice-Presidente de Ensino, Informação e Comunicação

Nísia Trindade Lima

\author{
EDITORA FIOCRUZ \\ Diretora \\ Nísia Trindade Lima \\ Editor Executivo \\ João Carlos Canossa Mendes \\ Editores Científicos \\ Carlos Machado de Freitas \\ Gilberto Hochman \\ Conselho Editorial \\ Claudia Nunes Duarte dos Santos \\ Jane Russo \\ Ligia Maria Vieira da Silva \\ Maria Cecília de Souza Minayo \\ Marilia Santini de Oliveira \\ Moisés Goldbaum \\ Pedro Paulo Chieffi \\ Ricardo Lourenço de Oliveira \\ Ricardo Ventura Santos \\ Soraya Vargas Côrtes
}

Coleção Saúde dos Povos Indígenas

Editores Responsáveis: Ricardo Ventura

Carlos E. A. Coimbra Jr. 
Saúde Indígena em Perspectiva: explorando suas matrizes históricas e ideológicas

Carla Costa Teixeira Luiza Garnelo organizadoras 
Copyright (C) 2014 dos autores

Todos os direitos desta edição reservados à

FUNDAÇÃO OSWALDO CRUZ / EDITORA

Revisão

Jorge Moutinho

M. Cecilia G. B. Moreira

Myllena Paiva

Capa

Danowski Design

Criada a partir da ilustração de pás para virar beijus.

Fonte: Entre os Aborígenes do Brasil Central, de Karl von den Steinen. São Paulo: Departamento de Cultura, 1940.

Projeto gráfico

Angélica Mello

Daniel Pose

Editoração eletrônica

Robson Lima (Obra Completa Comunicação)

Catalogação na fonte

Instituto de Comunicação e Informação Científica e Tecnológica

Biblioteca de Saúde Pública

T266s Teixeira, Carla Costa (Org.).

Saúde Indígena em Perspectiva: explorando suas matrizes históricas e ideológicas. / organizado por Carla Costa Teixeira e Luiza Garnelo. / - Rio de Janeiro: Editora FIOCRUZ, 2014.

262 p. : il. ; tab. (Coleção Saúde dos Povos Indígenas)

ISBN: 978-85-7541-449-1

1. Índios Sul-Americanos. 2. Políticas Públicas. 3. Sistema Único de Saúde. 4. Agentes Comunitários de Saúde - educação. 5. Capacitação em Serviço. 6. Saúde de Populações Indígenas. 7. Doenças Sexualmente Transmissíveis - prevenção $G$ controle. 8. Síndrome de Imunodeficiência Adquirida - prevenção G controle.

I. Garnelo, Luiza (Org.). II. Título.

CDD - 22.ed. - 980.41

2014

EDITORA FIOCRUZ

Av. Brasil, 4036 - 10 andar - sala 112 - Manguinhos

21040-361 - Rio de Janeiro - RJ

Editora filiada

Tels.: (21) 3882-9039 e 3882-9041

Telefax: (21) 3882-9006

editora@fiocruz.br

www.fiocruz.br

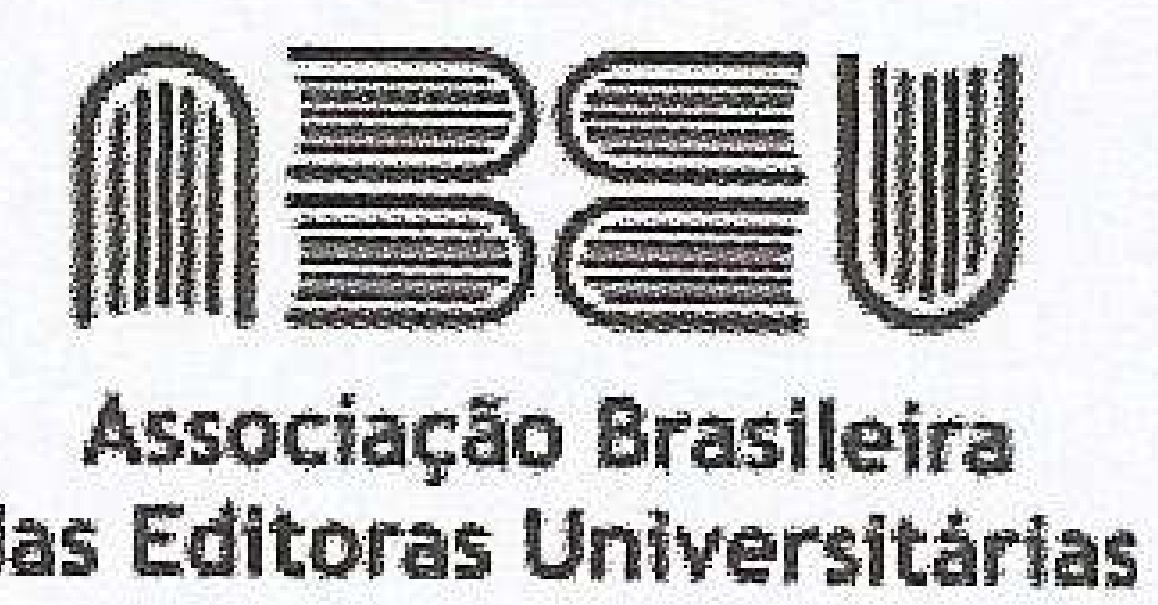


Autores

Antonio Carlos de Souza Lima é doutor em antropologia social pelo Programa de Pós-Graduação em Antropologia Social do Museu Nacional da Universidade Federal do Rio de Janeiro. É professor de etnologia da mesma instituição, pesquisador IB do CNPq e bolsista do Programa Cientistas do Nosso Estado da Faperj.

Carla Costa Teixeira (organizadora) é doutora em antropologia social pelo Programa de Pós-Graduação em Antropologia Social da Universidade de Brasília. É professora associada II do mesmo Programa e líder do Grupo de Pesquisa Antropologia Política da Saúde/CNPq.

Carolina Arouca é mestre em história das ciências e da saúde pelo Programa de Pós-Graduação em História das Ciências e da Saúde da Casa de Oswaldo Cruz da Fundação Oswaldo Cruz e doutoranda no mesmo Programa.

Cristina Dias da Silva é doutora em antropologia social pelo Programa de Pós-Graduação em Antropologia Social da Universidade de Brasília. É professora adjunta II do Departamento de Ciências Sociais da Universidade Federal de Juiz de Fora (UFJF), pesquisadora do Grupo de Pesquisa Antropologia Política da Saúde/ CNPq e coordenadora do Núcleo de Antropologia Tapuia da UFJF.

Eliana Elisabeth Diehl é doutora em saúde pública pela Escola Nacional de Saúde Pública Sérgio Arouca da Fundação Oswaldo Cruz. É professora e pesquisadora do Departamento de Ciências Farmacêuticas e do Programa de Pós-Graduação em Assistência Farmacêutica da Universidade Federal de Santa Catarina.

Esther Jean Langdon é doutora em antropologia pela Tulane University. É professora voluntária do Programa de Pós-Graduação em Antropologia Social da Universidade Federal de Santa Catarina, pesquisadora IB de CNPq e coordenadora do INCT Brasil Plural. 
Gilberto Hochman é doutor em ciência política pelo Instituto Universitário de Pesquisas do Rio de Janeiro. É pesquisador da Casa de Oswaldo Cruz da Fundação Oswaldo Cruz, professor do Programa de História das Ciências e da Saúde da mesma instituição.

Luiza Garnelo (organizadora) é doutora em antropologia pela Universidade Estadual de Campinas. É pesquisadora do Instituto Leônidas e Maria Deane da Fundação Oswaldo Cruz (Amazônia).

Nísia Trindade Lima é doutora em sociologia pelo Instituto Universitário de Pesquisas do Rio de Janeiro. É pesquisadora da Casa de Oswaldo Cruz da Fundação Oswaldo Cruz (COC/Fiocruz), professora do Programa de Pós-Graduação em História das Ciências e da Saúde da COC, vice-presidente de Ensino, Informação e Comunicação da Fiocruz.

Raquel Paiva Dias-Scopel é doutora em antropologia pelo Programa de Pós-graduação em Antropologia Social da Universidade Federal de Santa Catarina. É pesquisadora do Instituto Leônidas e Maria Deane da Fundação Oswaldo Cruz (Amazônia).

Renato da Silva é doutor em ciências pela Fundação Oswaldo Cruz com pós-doutorado em história pela Universidade do Estado do Rio de Janeiro. É professor adjunto doutor I do Programa de Pós-Graduação de Letras e Ciências Humanas da Unigranrio, membro do Comitê de Ética e Pesquisa da mesma universidade e bolsista de Produtividade Propesq I da Unigranrio/Funadesp.

Thiago Ávila (in memoriam) é mestre em antropologia social pela Universidade de Brasília. Atuou como antropólogo consultor da Equipe de Conservação da Amazônia (ACT) Brasil, de 2008 até a ocasião de seu falecimento. 


\section{Sumário}

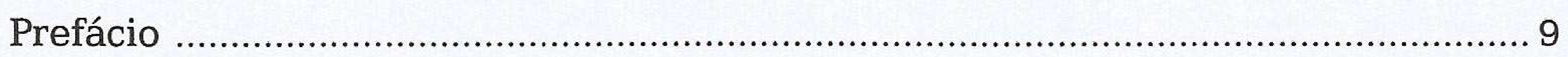

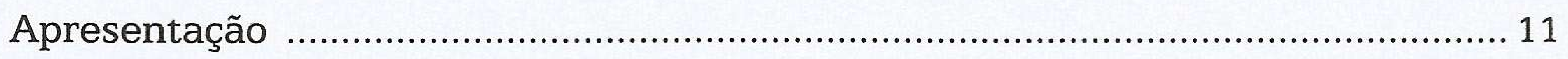

Parte I - As Matrizes Indigenistas e Sanitaristas

1. Revisitando a Tutela: questões para se pensar as políticas públicas para povos

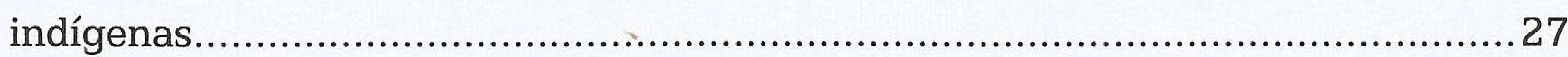

Antonio Carlos de Souza Lima

2. Antropologia e Medicina: a saúde no Serviço de Proteção aos Índios (1942-1956)... 59 Carolina Arouca e Nísia Trindade Lima

3. Campanhas Públicas, Populações (Quase) Invisíveis: endemias rurais e indígenas na saúde pública brasileira. 85

Gilberto Hochman e Renato da Silva

4. O SUS e a Saúde Indígena: matrizes políticas e institucionais do Subsistema de Saúde Indígena 107

Luiza Garnelo

Parte II - O Subsistema de Saúde Indígena em Ação

5. Do Museu aos Manuais: reflexões sobre o agente indígena de saneamento ... 145 Carla Costa Teixeira

6. De Improvisos e Cuidados: a saúde indígena e o campo da enfermagem .....181 Cristina Dias da Silva 
7. O Papel e a Formação dos Agentes Indígenas de Saúde na Atenção Diferenciada à Saúde dos Povos Indígenas Brasileiros ....

Esther Jean Langdon, Eliana Elisabeth Diehl e Raquel Paiva Dias-Scopel

8. Cultura, Sexualidade e Saúde Indígena: etnografia da prevenção das DST/Aids nos povos Timbira do Maranhão e do Tocantins .............................................241

Thiago Ávila 


\section{Prefácio}

Não seria necessário chegar ao fim da leitura de Saúde Indígena em Perspectiva, coletânea organizada por Carla Teixeira e Luiza Garnelo, para concluir que este volume constitui aporte necessário para reflexões sobre a gênese, as influências e os rumos das políticas públicas no campo da saúde dos povos indígenas no Brasil. Trata-se de um livro singular e relevante.

Sobretudo desde a década de 1980, vem sendo construído um sólido corpo analítico sobre a trajetória das políticas públicas voltadas para os povos indígenas. Profundamente impregnada pelos diálogos entre história e antropologia, um dos fios condutores dessa linha de análise tem sido a questão do poder tutelar, ou seja, o corpo de ideias e ações sistematicamente implementado pelo Estado e dirigido aos povos indígenas a partir do início do século XX. Esta coletânea expande para o campo da saúde indígena esse importante mote reflexivo sobre o chamado indigenismo, com particular atenção para as imbricações entre os contextos da macropolítica de longa duração e da microssociologia das interações de poder no cotidiano de atenção à saúde indígena, conforme Teixeira e Garnelo apontam na Apresentação.

Isolamento, extinção, marginalidade e vulnerabilidade são conceitos que permeiam muito das análises desenvolvidas nesta coletânea. São aqui dissecadas as matrizes ideológicas que têm norteado as ações estatais dirigidas aos povos indígenas, em geral pensados como habitando espaços distantes e recônditos, sem presença no futuro do país. Como mostram diversas contribuições neste livro, a imagem de um país cindido entre litoral e sertão, tão estruturante do pensamento social brasileiro ao longo do século $\mathrm{XX}$, refletiu-se também na saúde indígena. Nessa linha, em vários capítulos se aborda a inserção das ações de saúde dirigidas aos povos indígenas na narrativa mais ampla acerca da construção do imaginário de brasilidade.

Embora até os anos 1980 predominassem prognósticos de desaparecimento dos povos indígenas como segmentos culturalmente diferenciados, nas últimas três décadas houve não somente uma guinada demográfica, marcada por rápido crescimento populacional, como também um fortalecimento dos movimentos sociais e políticos alinhados com a defesa dos direitos indígenas no país. Assim, passou-se de 
um regime de concepção e gestão de ideias e pessoas pautado na perspectiva do eventual desaparecimento para outro, no qual a questão da permanência demográfica, sociocultural e política dos povos indígenas se firmou no horizonte. Ao longo do tempo, portanto, observa-se um amplo movimento do pêndulo, que vai desde políticas francamente assimilacionistas a outras que enfatizam o direito à diferença, o que se reflete nos mais diversos campos de atuação estatal, como a educação, a questão fundiária e a saúde. Por sua vez, os conteúdos da Constituição de 1988 podem ser vistos como a manifestação, no plano jurídico maior, dessa transformação.

Ao mesmo tempo que nos capítulos deste volume se evidenciam as camadas sob as camadas (históricas, políticas etc.) que influenciaram as matrizes ideológicas no campo da saúde indígena ao longo do século XX, a atual configuração das políticas públicas também está sob escrutínio. Por meio da análise dos documentos que embasam as atuais políticas em saúde, de um olhar antropológico para conteúdos musealizados derivados de ações da saúde pública e de pesquisas etnográficas sobre práticas de cuidado e a atuação de profissionais da saúde indígena, as contribuições aqui reunidas ajudam a compreender as mutações experimentadas nas matrizes ideológicas em tempos mais recentes.

As organizadoras, na Apresentação, chamam atenção para o aumento dos estudos no campo das ciências sociais sobre a saúde indígena, revertendo uma situação marcada pelo silêncio sobre o tema. Considero que essa transição a que aludem faz parte de um processo maior de mudança dos eixos e orientações da produção de conhecimento sobre a saúde indígena no Brasil. Nesse sentido, a perspectiva de reversão do silêncio na produção socioantropológica tem muitas complementaridades com a reversão da invisibilidade demográfica e epidemiológica dos povos indígenas que tem marcado o campo da saúde coletiva nas últimas décadas, e Saúde Indígena em Perspectiva é um importante passo na definitiva inserção do tema da saúde indígena nesse campo.

Espera-se que essas discussões, que focalizam as sociedades indígenas considerando sua permanência, cada vez mais se consolidem e se vinculem à crescente visibilidade das próprias vozes indígenas no cenário sociopolítico brasileiro. Os tempos atuais não são os mais favoráveis, de modo que um coro afinado de vozes, em seus diversos tons, faz-se cada vez mais necessário para garantir o avanço nas políticas públicas em prol dos povos indígenas.

\section{Ricardo Ventura Santos}

Pesquisador titular da Escola Nacional de Saúde Pública Sergio Arouca da Fundação Oswaldo Cruz e professor associado IV do Departamento de Antropologia do Museu Nacional da Universidade Federal do Rio de Janeiro 
Apresentação

Se há algo que chama a atenção na produção das ciências sociais sobre a saúde indígena no Brasil é o crescimento de suas investigações nos últimos dez anos. No que se refere ao volume de investigações, observa-se que de nove teses e dissertações produzidas na década de 1990 passou-se a 36, ou seja, um aumento de quatro vezes em dez anos (Teixeira G Dias da Silva, 2013). É claro que, se considerarmos o total de teses e dissertações das ciências sociais, esse número permanece proporcionalmente pequeno. Contudo, não podemos analisar a importância da antropologia nos estudos de saúde indígena somente por tais números. É preciso considerar sua relevância na interface com outros campos disciplinares, tais como: saúde coletiva, enfermagem, epidemiologia, psicologia etc. Referimo-nos à capacidade de diálogo que os antropólogos que pesquisam esse universo têm demonstrado e à escuta que vêm obtendo por parte de seus pares de outros campos de conhecimento. Na ausência de levantamentos sistematizados, um bom indicador do fôlego interdisciplinar da saúde indígena pode ser aferido pela consulta aos periódicos do campo da saúde. Uma consulta às bases bibliográficas virtuais mostra que, ao longo da primeira década do século XXI, observou-se um significativo incremento das publicações sobre saúde indígena.

Para a primeira década do século XXI, 38 títulos $^{1}$ - com interface entre ciências humanas, sociais e saúde - foram encontrados, sendo que 26 deles abordavam direitos indígenas à saúde, política, financiamento e gestão do Subsistema de Atenção à Saúde. Do total dessas 26 publicações, oito foram artigos em periódicos; sete foram livros ou capítulos de livro; e 11 publicações em páginas da web ou CD-ROM. Outros temas encontrados na revisão foram organização dos serviços de saúde nos Distritos Sanitários Especiais Indígenas (DSEIs) com quatro publicações encontradas (três artigos em periódicos e um capítulo de livro); cinco sobre controle social em saúde indígena, sendo três artigos em periódicos e dois capítulos de livros; e um artigo em página da web. Três artigos em periódicos não puderam ser classificados como agrupamento específico - um deles historiou a política de saúde indígena, outro tratou de saúde, cultura e desigualdades sociais e o terceiro abordou a Política de Saúde Indígena vista por meio de um museu. Também foi 
encontrado um livro tratando de transição alimentar e mudança cultural indígena. Outras publicações foram identificadas, mas excluídas deste levantamento por tratarem de temas pouco permeáveis ao campo das ciências sociais e saúde.

Para se entender esse incremento é preciso inseri-lo em pelo menos dois contextos mais abrangentes: 1) a ampliação dos programas de pós-graduação e do espaço de reflexão e troca de experiências de investigação propiciado pelas organizações científicas; ${ }^{2}$ e 2) o processo de democratização no país e a implantação do Subsistema de Saúde Indígena. Se o primeiro concerne ao dinamismo que a pós-graduação viveu a partir de sua modernização nos anos 1960,3 o segundo contexto - a nosso ver mais relevante para a compreensão do processo em foco refere-se à Constituição de 1988 em seus desdobramentos, tanto para os marcos legais dos direitos indígenas quanto para a saúde como um direito universal.

Muitos são os estudos sobre a importância da atual Constituição para o reconhecimento do direito dos indígenas de viverem segundo suas tradições e, portanto, do direito à existência em sua condição diferenciada; bem como para a afirmação legal de sua capacidade processual e, consequentemente, para o enfraquecimento do regime de tutela e fortalecimento das condições propiciadoras de articulações políticas regionais e nacional dos povos indígenas. ${ }^{4}$ Muitas são também as reflexões sobre o movimento de Reforma Sanitária que, tendo como marco a $8^{a}$ Conferência Nacional de Saúde em 1986, norteou os princípios que orientaram a universalização do direito à saúde nos termos do Sistema Único de Saúde (SUS) artigo 196 da Constituição de 1988 - e foi arena para alianças com o movimento indígena, contribuindo assim para a institucionalização de um subsistema diferenciado no âmbito do SUS para a atenção básica à saúde dos povos indígenas. 5

Pouco, entretanto, tem sido escrito sobre a centralidade desse processo político para a confluência de relevâncias empíricas e prioridades de agenda de pesquisa - sendo esta a hipótese em que apostamos -, que foi fundamental não só para o desenvolvimento das pesquisas das ciências sociais em saúde indígena, mas também para sua qualidade interdisciplinar e tendência a convergir em dois grandes eixos de investigação: 1) itinerários terapêuticos, práticas tradicionais e biomedicina, representações do adoecer e do curar; e 2) relações políticas em que se inserem os processos de adoecimento e cura, no que se refere tanto ao tipo de atenção à saúde prestada aos indígenas como à diversidade de formas de participação indígena na Política de Saúde Indígena - sem que, e isto é o mais interessante, essas ênfases distintas se cristalizem em grupos excludentes de pesquisadores (Teixeira G Dias da Silva, 2013).

Sob a inspiração dessa confluência, e atualizando-a aos desafios que ora se delineiam, foram escritos os capítulos reunidos nesta coletânea.

As inquietações teórico-investigativas que consolidaram a proposta de organizar uma publicação cujo mote seria refletir sobre as matrizes institucionais, 
históricas e ideológicas da saúde indígena remetem a duas lacunas detectadas na literatura afim. De um lado, o diálogo entre antropólogos, sociólogos e historiadores identificou um silêncio sobre os povos indígenas nos estudos desenvolvidos sobre a saúde pública no Brasil; de outro, a interação contínua entre antropólogos estudiosos da saúde indígena e do indigenismo revelou a carência de reflexão sobre a afinidade observada entre os valores e práticas da tutela indígena e os da política diferenciada para a saúde indígena.

Nessa perspectiva, um horizonte comum de preocupações teóricometodológicas foi se delineando nos encontros entre os pesquisadores (simpósios, seminários, bancas de mestrado e doutorado, grupos de trabalho e publicações conjuntas), incluindo os - mas não apenas entre eles 6 - colaboradores desta publicação. No percurso de tradução de tais preocupações na organização desta coletânea, reconhecemos transformações que qualificam a concretização de qualquer projeto em uma ação no mundo. Contudo, a compreensão originalmente compartilhada manteve sua dupla orientação. Por um lado, a necessidade de se levar em consideração o processo político nacional de mais longa duração para investigar a realidade indígena no que concerne às ações contemporâneas em saúde; por outro, o entendimento acerca da imprescindível articulação entre os contextos da macropolítica e os da microssociologia das interações de poder no cotidiano de atenção à saúde indígena.

Assim, a contribuição dos autores que participam deste livro deve ser entendida como um esforço conjunto de entendimento da atual política pública de saúde indígena à luz de seus antecedentes históricos no que concerne à configuração de valores e da engenharia institucional, tanto no âmbito das políticas de saúde quanto no das políticas indigenistas. Mediante esse recorte, todos buscaram ampliar a compreensão dos limites e possibilidades da implementação do Subsistema de Saúde Indígena, assim como da produção de diretrizes políticas nas instâncias governamentais de interesse na implementação das políticas sociais dirigidas às minorias étnicas no país e dos resultados até aqui obtidos.

Organizada em duas partes - a primeira intitulada "As matrizes indigenistas e sanitaristas" -, esta coletânea tem início com o "Revisitando a tutela: questões para se pensar as políticas públicas para povos indígenas", produzido por Antonio Carlos de Souza Lima, que delineia um consistente perfil de atuação do Estado brasileiro no tocante aos povos indígenas. O autor debruça-se sobre a trajetória do poder tutelar, caracterizado pelo monopólio dos atos de definir e controlar a população sobre a qual ele incide; esmiúça os campos de conhecimento que o constituíram, as formas que assumiu ao longo do contato interétnico e os modos intrínsecos como se ligou à própria formação da nação brasileira. O argumento de Souza Lima leva a uma interessante reflexão sobre os desdobramentos da política indigenista que, se por um lado diferencia os grupos étnicos ao torná-los objeto de uma proteção espe- 
cial, por outro nega suas singularidades ao objetificá-los como "índios genéricos". Tal movimento os torna alvo da ação padronizada do órgão indigenista e de seus agentes, que intervêm de modo abrangente, não apenas em âmbito nacional, mas também nos ambientes microcotidianos das aldeias, onde geram novas formas de socialização produzidas na interface de colonizador e colonizados que expressam a ação diferenciada do indigenismo moderno. O autor se interroga - e direciona esta indagação também para o leitor - sobre continuidades/descontinuidades que possam existir entre a ação do órgão indigenista oficial e aquela exercida pelos agentes sanitários, cujas origens e trajetórias são muito distintas daquelas percorridas pelo sertanismo oficial.

Souza Lima encontra pontos comuns entre a ação indigenista e as práticas dos profissionais da saúde cujo domínio sobre técnicas salvadoras de vidas, associadas ao caráter heroico e messiânico autoatribuído ao trabalho que desenvolvem, redundam - deliberada ou involuntariamente - em destituição da legitimidade dos saberes indígenas sobre a doença e a saúde, de resto desconhecidos pelos especialistas em saúde. Ainda que operando em contextos contemporâneos e em espaços sanitários que só recentemente passaram a povoar o cenário das relações interétnicas, tais práticas sanitárias - assim como as indigenistas - ativam no seu cotidiano as estratégias tutelares de minorização das populações indígenas, revelando a abrangência e a capilaridade da ideologia tutelar do indigenismo muito além das suas instituições originárias.

No capítulo seguinte, "Antropologia e Medicina: a saúde no Serviço de Proteção aos Índios (1942-1956)", Carolina Arouca e Nísia Trindade Lima efetuam um estudo da trajetória de órgãos de interesse para as políticas de saúde e a política indigenista, no espaço de tempo compreendido entre as décadas de 1940 e 1950. Mediante um acurado olhar sobre a atuação do Serviço de Proteção aos Índios (SPI) - e em particular sobre a seção de estudos deste órgão, a qual teve contribuição relevante para a formulação das políticas indigenistas no período -, as autoras destacam a criação do Serviço de Unidades Sanitárias Aéreas (Susa) do Serviço Nacional de Tuberculose, responsável pelo atendimento nas aldeias, e dimensionam suas estratégias institucionais para transformar tal cuidado em política pública. Em sua busca de explicar a ausência da temática indígena nas políticas nacionais de saúde pelo menos até a década de 1950, Arouca e Lima avançam na análise da fragmentação das instituições públicas encarregadas desses distintos campos de ação (sanitária, indigenista, endemias rurais e outros) e dos meandros da ambígua relação entre o Estado nacional, as populações indígenas e as concepções das elites sobre nacionalidade. Analisam as interfaces e os desencontros do indigenismo sanitário com as ações do Departamento Nacional de Saúde, cujo foco principal era a população sertaneja, vista como elemento-chave na construção da nação, o que teve, entre suas implicações, o não estabelecimento de prioridades 
para os problemas sanitários das populações indígenas mantidas na obscuridade pelas políticas oficiais de saúde, apesar dos esforços do Susa.

O terceiro capítulo, "Campanhas públicas, populações (quase) invisíveis: endemias rurais e indígenas na saúde pública brasileira", produzido por Gilberto Hochman e Renato da Silva, trata de um tema bastante original: a invisibilidade dos povos indígenas para as autoridades sanitárias do país, ao longo de quase todo o século XX. A temática se reveste de especial importância quando lembramos que as primeiras décadas daquele século foram aquelas em que os poderes estatais encastelados no litoral do país empreenderam a conquista sistemática dos chamados "sertões", representados, na época, pelo Planalto Central e pela Amazônia. Naquele momento, de acordo com os autores, ainda que a população majoritária nos espaços rurais fosse formada por indígenas e mestiços (caboclos), oriundos dos fluxos e refluxos do processo colonizador que era apenas intermitente até o início do século XX, eles nunca foram priorizados pelo sanitarismo campanhista, em que pese a propalada preocupação com as condições de saúde dos trabalhadores rurais.

Ainda que desenvolvam abordagens distintas, Arouca e Lima partilham com Hochman e Silva a análise do cenário evolucionista que produziu a política indigenista no Brasil, marcada pela ideia de degradação progressiva das culturas indígenas, tomadas como inferiores ou insuficientemente desenvolvidas, e de sua inexorável metamorfose em sertanejos, estes sim, entendidos como destinatários de políticas sociais, ou pelo menos da retórica dos governantes. Porém, independentemente de qualquer retórica oficial, indígenas e sertanejos igualavam-se na mesma carência de acesso aos serviços e ações de saúde.

Não sendo monolíticas, tais iniciativas coexistiam com uma preocupação humanística com a preservação dessas culturas, antes que se extinguissem, e com as denúncias de uma péssima situação sanitária dos povos indígenas, empreendidas por uma militância instalada no órgão indigenista oficial, interessada em associar a investigação antropológica com ações voltadas para a solução de problemas cotidianos enfrentados pelos grupos étnicos. Nesse âmbito destaque-se a atuação de Darcy Ribeiro, tido como um dos antropólogos que mais adentraram o campo da saúde. Ao se recusar a adotar uma explicação empobrecedora e unicausal de uma suposta incapacidade biológica indígena para enfrentar os agentes transmissores de doenças, ele logrou sucesso em demonstrar as correlações entre epidemias, declínio demográfico indígena e efeitos deletérios do contato interétnico, promovendo um salto de qualidade nas explicações causais então vigentes.

Para Hochman e Silva, se tais discussões estavam intimamente ligadas a um imaginário de brasilidade forjado por cronistas e romancistas como Euclides da Cunha e Monteiro Lobato, que atribuíram (positiva ou negativamente) aos sertanejos a condição de alicerce da nação, elas coexistem com o vívido retrato feito por sanitaristas que denunciavam as mazelas das populações rurais e ten- 
tavam saneá-las mediante a adoção de tecnologias biomédicas de prevenção e tratamento de doenças transmissíveis. Tão invisíveis quanto os indígenas eram as desigualdades sociais que estavam na origem dos elevados perfis de morbimortalidade denunciados pelos sanitaristas em seus relatórios e missões nas áreas rurais do país. Entretanto, se os sertanejos foram incorporados como elementos de construção da nação, a ser integrada e consolidada mediante a adição dos sertões ao cenário econômico daquele período, o mesmo não ocorreu com os índios, que permaneceram a cargo do SPI, mantendo-se a disjunção entre a ação de governo e as necessidades das minorias, que perdurou até os anos 1990. A invisibilidade indígena, porém, não se traduzia em ausência de intervenção governamental; sua capacidade de dificultar a penetração das frentes econômicas nas áreas ainda ermas do país continuou exigindo ação indigenista com vistas a pacificá-los. Já no campo da saúde, a prestação de ações sanitárias dirigidas aos indígenas prosseguiu, ainda que sem reconhecimento de sua identidade singular. A continuidade dessas estratégias persistiu até a segunda metade do século $\mathrm{XX}$, sendo alterada somente durante a ditadura militar, que tirou os povos indígenas da condição de invisíveis, ainda que fosse para elegê-los como inimigos internos da nação, que obstaculizavam a colonização da Amazônia.

Voltado para um período histórico mais recente, o texto de Luiza Garnelo, "O SUS e a saúde indígena: matrizes políticas e institucionais do Subsistema de Saúde Indígena", debruça-se na análise do contexto político e institucional que instituiu o SUS e um de seus produtos, de interesse para a presente obra, o Subsistema de Saúde Indígena. Tomando como eixo de investigação as políticas sociais, particularmente aquelas voltadas para a inclusão social, a autora mapeia os atores e os processos políticos relevantes para a emergência e consolidação da Política Nacional de Atenção à Saúde dos Povos Indígenas (PNASPI) a partir da década de 1990, já no interior do campo da saúde e em franco afastamento do campo indigenista que monopolizou o sanitarismo indigenista nas décadas anteriores.

Tal polarização recobre, segundo a autora, a coexistência de duas modalidades distintas de política social: o modelo de assistência social, praticado pelo indigenismo oficial, fundado na premissa de uma incapacidade social de seus beneficiários; e o da seguridade, pautado pelo princípio da igualdade entre cidadãos, que rege a política vigente no SUS e propiciou a emergência de uma política de saúde dirigida aos povos indígenas. Polarização simétrica ela encontrou na preponderância do gestor federal na atuação indigenista clássica, em contraponto ao protagonismo atribuído aos poderes locais/municipais pela política do SUS, gerando contradições - até o momento insolúveis - na operacionalização da Política de Saúde Indígena. Garnelo revisa os instrumentos de gestão e regulação das políticas de inclusão social, como leis, decretos, portarias e planos plurianuais de governo, buscando apreender como neles se expressa, ao longo das últimas décadas, a 
prioridade (ou a ausência dela) dada às minorias indígenas nas iniciativas de inclusão social que visavam à redução de iniquidades.

Atenção especial foi dada à atuação da Fundação Nacional de Saúde (Funasa), órgão que recebeu a incumbência de implantar o Subsistema de Saúde Indígena. A Funasa é retratada como pouco permeável às mudanças imprimidas à política nacional de saúde pelo movimento da Reforma Sanitária, o que teria contribuído para a fraca incorporação desse subsistema aos planos maiores de tomada de decisão no SUS, algo constatado na análise documental empreendida pela autora.

A segunda parte do livro, intitulada "O subsistema de saúde indígena em ação", compreende um conjunto de textos que tratam de temas específicos de alta relevância para a análise das ações desenvolvidas no Subsistema de Saúde Indígena. Em termos gerais, podem ser classificados como estudos sobre a operacionalização da Política de Saúde Indígena que exploram certas facetas da atuação institucional como a da Funasa e de outros personagens, como os agentes de saúde e de saneamento, médicos, enfermeiros, ao lado de outros que atuam em âmbito comunitário, independentemente da ação institucional.

O primeiro capítulo da segunda parte, intitulado "Do museu aos manuais: reflexões sobre o agente indígena de saneamento", é de autoria de Carla Costa Teixeira. Por meio do escrutínio etnográfico e documental do museu da Funasa e dos manuais de saneamento escritos nos anos 1940 e 1970 por engenheiros do Serviço Especial de Saúde Pública (Sesp), ela se propõe a entender "a relação entre conhecimento sobre o mundo e ação no mundo" por meio dos elementos analíticos selecionados. Empreende uma arqueologia das ações de saneamento implementadas a partir dos anos 2000 pelos agentes indígenas de saneamento, sob responsabilidade da Funasa; investiga as matrizes de origem dessas atividades, reconhecidas no trabalho dos agentes sanitários que atuaram, em décadas anteriores, nas instituições que confluíram para a formação da Funasa. Nessa trajetória, a autora elege como foco principal de seu interesse alguns elementos icônicos veiculados pelo museu, como os manuais de saneamento e seus operadores, os guardas sanitários - da Superintendência de Campanhas de Saúde Pública (Sucam) e da Fundação Sesp - e seus sucedâneos modernos, os agentes indígenas de saneamento. Ainda que produzidas em momentos temporalmente distintos, a autora confirma uma continuidade entre concepções e valores das estratégias de ação dos anos 1940 e as ações empreendidas no século XXI. No caso das modernas ações do Subsistema de Saúde Indígena, ela investiga como se expressam - e se têm expressão - as diferenciações que devem caracterizar uma política dirigida às minorias étnicas, encontrando uma concepção de saneamento que também remonta aos anos 1940.

A análise dos diferentes manuais de saneamento mostrou que, mesmo separados entre si por décadas, eles guardam relevante continuidade na tradição higienista que os fundamenta. No que se refere a esse tema, a autora assinala, no 
Manual do Agente Indígena de Saneamento da Funasa, a produção de uma imagética que naturaliza a convivência indígena com lixo e sujeira, dos quais escapariam somente por meio do processo civilizatório mediado pela higiene e pelo saneamento, os únicos capazes de modificar as condutas insalubres e retirá-los de sua condição incivilizada. No conjunto, os materiais reforçam a ideia de uma natureza indígena moralmente desqualificada, a ser resgatada pelo processo civilizatório, a despeito de si própria. Ao articular a análise de um museu institucional com a de um conjunto de manuais governamentais, a autora busca assim iluminar duas formas de conformação dos agentes estatais na saúde pública e seus desdobramentos na saúde indígena: a fabricação e o compartilhamento de certa memória pública e a produção de uma moral particular naturalizada sob a manualização de alegadas orientações técnicas universais.

Na sequência, Cristina Dias da Silva analisa, no capítulo "De improvisos e cuidados: a saúde indígena e o campo da enfermagem", certas conjunções e disjunções que cercam a prestação dos serviços de saúde, calcada numa lógica do conflito no interior das equipes multidisciplinares de saúde indígena (EMSIs), em um DSEI localizado no estado do Pará. Dias da Silva faz uma abordagem, inédita nas publicações em saúde indígena, sobre as práticas assistenciais desenvolvidas no DSEI estudado, buscando apreender o lugar da diferenciação da atenção à saúde, considerada como um dos pilares da Política Nacional de Atenção à Saúde Indígena. Ao lado dos elementos explicitados, a autora apreende categorias implícitas - mas plenamente operantes - como o higienismo, que ela recomenda que seja visto, simultaneamente, como um corpo de conhecimentos e práticas, mas, também, de uma espécie de conceito-valor que subjaz às práticas de busca ativa e de promoção da saúde, cujos sentidos originais foram ressignificados pelos profissionais que atuam no DSEI. Assim, a investigação revela também elementos do higienismo civilizador em ação na saúde indígena contemporânea que outro trabalho de Teixeira (2012) já havia indicado na sua proposta de arqueologia do Manual do Agente Indígena de Saneamento.

A análise remete também à constituição do campo da enfermagem no Brasil, representado, no texto, pela atuação de Anna Nery, entendida como figura-chave na constituição da enfermagem como campo profissional no país. A atuação empírica de Anna Nery, orientada pela prestação de cuidado, é retomada num plano mais gerencial - sob influência das correntes inglesas de atuação da enfermagem - na constituição da Escola de Enfermagem Anna Nery, no Rio de Janeiro, a qual operou como modelo estruturante do processo formador desses profissionais em território nacional. Tais modelos de atuação foram reencontrados no campo de pesquisa mediante a atuação dos profissionais de enfermagem no DSEI investigado. Ali a autora assinala a importância da hierarquia nas rotinas de trabalho da enfermagem, que separam os que executam dos que administram a prestação do cuidado, algo 
característico do pensamento ocidental e alheio aos modos indígenas de pensar e agir. Assim, o que seria diferenciado, na atenção prestada à saúde, torna-se mais afeto aos valores do colonizador, inviabilizando a preconizada diferenciação da atenção.

Esther Jean Langdon, Eliana Elisabeth Diehl e Raquel Paiva Dias-Scopel elegeram como objeto de seu interesse a figura do agente indígena de saúde. No capítulo "O papel e a formação dos agentes indígenas de saúde na atenção diferenciada à saúde dos povos indígenas brasileiros", fazem um apanhado da literatura e da documentação institucional disponível, analisando as características e o perfil de atuação previstos nos dispositivos legais e institucionais que regulam a inserção dos agentes de saúde no Subsistema de Saúde Indígena. As autoras inovam ao cotejarem o cenário institucional com a dinâmica política interna dos próprios grupos étnicos de origem dos agentes de saúde, demonstrando como ela molda o processo de escolha desses profissionais, influencia suas práticas sanitárias na comunidade e expressa uma ressignificação das normas técnicas oriundas do subsistema de saúde. Exploram, para certos contextos, a influência político-partidária, tanto na escolha quanto na atuação dos agentes de saúde, demonstrando que tais interfaces com o poder político não indígena também são parte integrante do modo de viver indígena no mundo contemporâneo e não podem ser ignoradas. Alertam também para o fato de que a variabilidade nos cenários sociais encontrados está simultaneamente ligada às características, à regularidade e à intensidade do contato interétnico, bem como ao ethos do grupo.

Uma paradoxal - e diretamente proporcional - relação entre a presença constante e regular dos profissionais não indígenas das EMSIs e uma atuação menos definida e mais ambígua no trabalho dos agentes indígenas de saúde (AISs) é evidenciada por Langdon, Dhiel e Dias-Scopel. Contrariamente, nos locais em que a presença das equipes técnicas é menor ou descontinuada, as autoras encontraram processos de trabalho mais bem delimitados e o desenvolvimento de ações mais efetivas e resolutivas por parte dos AISs. Também demonstram a baixa racionalidade de certas atribuições impostas a eles, como as visitas domiciliares, que são concebidas segundo a lógica impessoal da moradia em espaços urbanos, mas amplamente desnecessárias no contexto da aldeia, onde predominam as relações face a face, com circulação contínua e imediata das informações sobre os eventos do cotidiano. A falta de um conhecimento mínimo, por parte dos profissionais não indígenas, da teia de relações etnopolíticas que sustenta a atuação dos AISs nas comunidades e no seu grupo de parentesco surge como outro ponto de fragilidade na efetivação de um modelo culturalmente adaptado de atenção à saúde.

No último capítulo, "Cultura, sexualidade e saúde indígena: etnografia da prevenção das DST/Aids nos povos Timbira do Maranhão e do Tocantins", Thiago Ávila produziu uma etnografia das situações de intermedicalidade estabelecidas entre os povos Timbira e o sistema oficial de saúde. Ele demonstra que a criação 
de interfaces de dois sistemas explicativos da doença, cura e cuidado (o sistema médico oficial e o sistema indígena) estabelece interações criativas que reforçam identidades e preceitos nos diálogos entre alteridades, que se estruturam em torno da temática das doenças sexualmente transmissíveis (DST) e da Aids. Em abordagem fecunda e original, o autor efetua, segundo seus próprios termos, uma verdadeira cartografia das relações entre cultura, sexualidade e sistemas médicos indígenas e ocidentais; demonstra conexões entre as concepções e práticas indígenas, seus diferentes rituais e a transmissão das DST, mas sem descurar da investigação sobre a influência e as consequências das tensões interétnicas na vida social do povo Timbira. Também demonstra a potencialidade de sua pesquisa para contribuir com a provisão de uma atenção sanitária culturalmente sensível, na medida em que não apenas assinala as diferenças entre os sistemas médicos em interatuação, mas também demonstra caminhos de articulação possíveis entre eles, mediante os processos de recolonização, que geram apropriações e incorporação, na cosmologia indígena, dos saberes coloniais que lhes são franqueados, contribuindo de forma ativa para a produção da zona de intermedicalidade etnografada pelo autor.

Concluída a súmula das ideias e proposições veiculadas pelos autores que contribuíram para esta obra, convidamos o leitor a apreciar aquela que representa, sem dúvida, um relevante aporte para a compreensão das origens e dos rumos futuros da Política de Saúde Indígena no Brasil. A rentabilidade dessas preocupações, em que pese nossa avaliação positiva, poderá ser avaliada pelo próprio leitor no percurso dos trabalhos aqui reunidos. Boa leitura!

As organizadoras

Notas

1 Ver Publicações sobre Saúde Indígena ao final desta Apresentação.

2 Destacamos as bienais Reuniões Brasileiras de Antropologia, Reuniões de Antropologia do Mercosul, Reuniões de Antropologia do Norte e Nordeste e as reuniões anuais da Associação Brasileira de Saúde Coletiva (Abrasco).

3 Para os interessados, consultar Trajano Filho e Ribeiro (2004).

4 Dentre a produção mais recente, consultar Souza Lima (2010) e Araújo e colaboradores (2006).

5 Para uma abordagem abrangente desse campo de pesquisa, ver Lima e colaboradores (2005) e Langdon e Garnelo (2004).

6 Dentre os pesquisadores que vêm mantendo interlocução nas diferentes atividades organizadas em eventos científicos em torno dessa temática, citamos especialmente as antropólogas Marina Cardoso e Jane Beltrão. 


\section{Referências}

ARAÚJO, A. V. et al. Povos Indígenas e a Lei dos "Brancos": o direito à diferença. Brasília: Ministério da Educação, Secretaria de Educação Continuada, Alfabetização e Diversidade, Laced/Museu Nacional, 2006.

LANGDON, E. J. G GARNELO, L. (Orgs.). Saúde dos Povos Indígenas: reflexões sobre antropologia participativa. Rio de Janeiro, Brasília: Contra Capa, Associação Brasileira de Antropologia, 2004.

LIMA, N. T. et al. (Orgs.). Saúde, Democracia, História e Perspectivas do SUS. Rio de Janeiro: Fiocruz, 2005.

SOUZA LIMA, A. C. Poder tutelar y formación del Estado en Brasil: notas a partir de la creación del Servicio de Protección a los Indios y Localización de Trabajadores Nacionales. Desacatos. Revista de Antropología Social, 33: 53-66, 2010.

TEIXEIRA, C. C. A produção política da repulsa e os manejos da diversidade na saúde indígena brasileira. Revista de Antropologia, 55(2): 1-37, 2012.

TEIXEIRA, C. C. G DIAS DA SILVA, C. Antropologia e saúde indígena: mapeando marcos de reflexão e interfaces de ação. Anuário Antropológico, 2012: 35-57, 2013.

TRAJANO FILHO, W. G RIBEIRO, G. L. (Orgs.). O Campo da Antropologia no Brasil. Rio de Janeiro, Brasília: Contra Capa, Associação Brasileira de Antropologia, 2004.

\section{Publicações sobre Saúde Indígena}

AITH, Fernando. Saúde indígena no Brasil: atual quadro jurídico-administrativo do estado brasileiro e desafios para a garantia do direito à saúde da população indígena. Revista de Direito Sanitário, 9(3): 115-132, 2008.

ATHIAS, Renato G MACHADO, Marina. 2001. A saúde indígena no processo de implementação dos Distritos Sanitários: temas críticos e propostas para um diálogo interdisciplinar. Cadernos de Saúde Pública, 17(2): 425-431, 2001.

CHAVES, Maria Betânia Garcia Chaves; CARDOSO, Andrey Moreira G ALMEIDA, Celia. Implementação da política de saúde indígena no Pólo-Base Angra dos Reis, Rio de Janeiro, Brasil: entraves e perspectivas. Cadernos de Saúde Pública, 22(2): 295-305, 2001.

COIMBRA JR., Carlos E. A. G SANTOS, Ricardo Ventura. Saúde, minorias e desigualdade: algumas teias de inter-relações, com ênfase nos povos indígenas no Brasil. Ciência $G$ Saúde Coletiva, 5(1): 125-132, 2000.

COIMBRA JR., Carlos E. A. et al. The Xavante in Transition: health, ecology and bioanthropology in Central Brazil. Ann Arbor: University of Michigan Press, 2002. 
COMISSÃO PRÓ-YANOMAMI (CCPY). Saúde Indígena. Impasse no Modelo de Gestão: a saga das reformas na saúde indígena (1967-1999). Disponível em: <www.socioambiental.org/ banco_imagens/pdfs/ccpy.pdf>. Acesso em: 11 set. 2014.

DIEHL, Eliana G LANGDON, Esther J. Políticas de Controle Social em Contextos Interculturais: impasses e desafios para a saúde indígena brasileira, 2009. Disponível em: <www. laced.mn.ufrj.br/indigenismo/arquivos/Diehl_G_Langdon_Artigo_GT12_VIII_RAM_2009. pdf>. Acesso em: set. 2014.

DODGE, Raquel Elias Ferreira. Povos indígenas: direito, ética e controle social. Boletim dos Procuradores da República, 4(38): 14-18, 2001.

FERNANDES, Maria Neyrian de Fátima et al. Um breve histórico da saúde indígena no Brasil. Revista de Enfermagem UFPE On Line, 4(spe): 1.951-1.960, 2010.

GARNELO, Luiza. Aspectos socioculturais de vacinação em área indígena. História, Ciências, Saúde - Manguinhos, 18(1): 175-190, 2011.

GARNELO, Luiza. Análise situacional da política de saúde dos povos indígenas no período de 1990 a 2004: implicações no Brasil e na Amazônia. In: SCHERER, Elenise G OLIVEIRA, José Aldemir (Orgs.). Amazônia: políticas públicas e diversidade cultural. Rio de Janeiro: Garamond, 2006.

GARNELO, Luiza; MACEDO, Guilherme G BRANDÃO, Luiz C. Os povos indígenas e a construção das políticas públicas no Brasil. Brasília: Opas, 2003.

GARNELO, Luiza G SAMPAIO, Sully. Bases socioculturais do controle social em saúde indígena. Cadernos Saúde Pública, 19(1): 311-318, 2003.

HOFFMANN, Maria Barroso et al. Administração pública e os povos indígenas. In: ROCHA, Denise G BERNARDO, Maristela. (Orgs.). A era FHC e o Governo Lula: transição? 1. ed. Brasília: Edição Inesc, 2004. 1 v.

INSTITUTO DE ESTUDOS SOCIOECONÔMICOS (INESC). PPA 2008/2011: as prioridades do governo Lula. Boletim Inesc, 7(13): 1-7, 2007. Disponível em: <www.inesc.org.br/ biblioteca/publicacoes/artigos/ARTIGO\%20PPA\%202008\%202011.pdf/view>. Acesso em: set. 2014.

LANGDON, Esther J. Salud y pueblos indígenas: los desafíos en el cambio de siglo. In: BRICEÑO-LEÓN, Roberto; MINAYO, Maria Cecilia G COIMBRA JR, C. (Orgs.). Salud y Equidad: una mirada desde las ciencias sociales. 1 ed. Rio de Janeiro: Editora Fiocruz, 2000.

LANGDON, Esther J. Uma avaliação crítica da atenção diferenciada e a colaboração entre antropologia e profissionais de saúde. In: LANGDON, Esther J. G GARNELO, Luiza (Orgs.). Saúde dos povos indígenas: reflexões sobre antropologia participativa. Rio de Janeiro: Contra Capa, Associação Brasileira de Antropologia, 2004.

LANGDON, Esther J. Diversidade cultural e os desafios da política brasileira de saúde do índio. Saúde e Sociedade, 16: 7-12, 2007.

LANGDON, Esther J. G DIEHL, Eliana. Participação e autonomia nos espaços interculturais de saúde indígena: reflexões a partir do Sul do Brasil. Saúde e Sociedade, 16: 19-36, 2007. 
LANGDON, Esther J. et al. A participação dos agentes indígenas de saúde nos serviços de atenção à saúde: a experiência em Santa Catarina. Cadernos de Saúde Pública, 22(12): 2.637-2.646, 2006.

LIMA, Antonio Carlos de Souza. Povos indígenas no Brasil contemporâneo: de tutelados a 'organizados'? In: SOUZA, Inglez et al. (Org). Povos Indígenas: projetos e desenvolvimento II. Brasília, Rio de Janeiro: Paralelo 15, Laced, 2010.

LIMA, Nísia Trindade et al. (Org.). Saúde e Democracia: história e perspectivas do SUS. Rio de Janeiro: Editora Fiocruz, 2005.

PELLEGRINI, Marcos et al. Componente Atenção. In: Consórcio IDS-SSL-Cebrap Diagnóstico Situacional do Subsistema de Saúde Indígena, 2009.

PONTES, Ana Lúcia G GARNELO, Luiza. A construção do modelo de atenção diferenciada para a saúde indígena no Brasil e a integralidade. In: PINHEIRO, Roseni G SILVA JR., Aluisio G. (Orgs.). Por uma Sociedade Cuidadora. Rio de Janeiro: Cepesc, IMS, Uerj, 2010.

SANTOS, Ricardo V. et al. Saúde dos povos indígenas e políticas públicas no Brasil. In: GIOVANELLA, Lígia et al. (Orgs.). Políticas e Sistema de Saúde no Brasil. Rio de Janeiro: Editora Fiocruz, 2008.

SOUZA, Helcio. Políticas públicas para povos indígenas: uma análise a partir do orçamento. Nota Técnica Inesc n. 38. Brasília, 9 out. 2000. Disponível em: <www.inesc.org.br>. Acesso em: set. 2014.

SOUZA, Maria da Conceição; SCATENA, João H. G. G SANTOS, Ricardo V. O Sistema de Informação da Atenção à Saúde Indígena (Siasi): criação, estrutura e funcionamento. Cadernos de Saúde Pública, 23(4): 853-861, 2007.

SOUZA LIMA, Antonio C.; IGLESIAS, Marcelo P. G BARROSO-HOFFMAN, Maria. O novo PPA e as políticas públicas para os povos indígenas. Boletim do Inesc (Orçamento $G$ Política Socioambiental), 2(6): 1-11, jun. 2003.

TEIXEIRA, Carla Costa. Fundação Nacional de Saúde: a política brasileira de saúde indígena vista através de um museu. Etnográfica, 12(2): 323-351, 2008.

VARGA, István van Deursen. Fronteiras da urbanidade sanitária: sobre o controle da malária. Saúde e Sociedade, 16(1): 28-44, 2007.

VARGA, István van Deursen. Secretaria Especial de Atenção à Saúde Indígena: desafios. Boletim do Instituto de Saúde, 129(2): 167-171, 2010.

VARGA, István van Deursen G ADORNO, Rubens de C. F. Terceirizando a indianidade? Sobre a política nacional de saúde para os povos indígenas, aos ' 500 anos'. Revista de Direito Sanitário 2(1): 9-26, 2001.

VARGA, István van Deursen G VIANA, Rosana L. Distrito Sanitário Especial Indígena do Maranhão: crônicas de um desastre anunciado. Revista de Direito Sanitário, 9(3): 133149, 2009. 
VERDUM, Ricardo. Avanços e retrocessos da política indigenista. Boletim Orçamento $G$ Política Socioambiental, n. 12. Brasília: Instituto de Estudos Socioeconômicos, 2005.

VERDUM, Ricardo. Perdas e ganhos no orçamento indigenista do governo federal. In: RICARDO, Carlos A. G RICARDO, Fanny (Orgs.). Povos Indígenas do Brasil: 2001-2005. São Paulo: Edição Instituto Socioambiental, 2006.

VERDUM, Ricardo. El indigenismo brasileño en tiempos de multiculturalismo. Alteridades 18(35): 33-46, 2008.

VERDUM, Ricardo. Orçamento indigenista da União no PPA 2008-2011, s.d. Disponível em: <www.inesc.org.br/publicações/textos>. Acesso em: 20 jun. 2011.

VERDUM, Ricardo. A cidadania multicultural e os limites do indigenismo brasileiro, 2000. Disponível em: <www.ciesas.edu.mx/proyectos/relaju/documentos/Verdum_Ricardo. pdf $>$. Acesso em: set. 2014. 
As Matrizes Indigenistas e Sanitaristas 


\section{Revisitando a Tutela: questões para se pensar as políticas públicas para povos indígenas ${ }^{1}$}

Antonio Carlos de Souza Lima

Este capítulo tem como objetivo abordar a ideia de tutela sobre os povos indígenas como um exercício de poder, pretendendo contribuir para o estudo das políticas indigenistas contemporâneas, em especial aquele sobre a política de saúde indígena, por meio de subsídios para a análise de uma das matrizes que a ensejou a ação estatal de proteção aos povos indígenas no contexto do regime republicano no Brasil do início do século XX. Afinal, uma pergunta se impõe a quem observa a ação sanitária governamental sobre indígenas hoje: como os profissionais da área da saúde que mantêm contatos relativamente recentes com os povos indígenas tornam-se em seu exercício profissional cotidiano tão rapidamente próximos dos modos de agir do Serviço de Proteção aos Índios (SPI) e da Fundação Nacional do Índio (Funai)?

De modo mais direto, refiro-me à necessidade de se pensar nas formas como se dá a transmissão de conhecimentos para o exercício de poderes de Estado sobre os povos indígenas, situação em que estes são tratados como um segmento populacional sob a responsabilidade de uma agência de governo da esfera administrativa federal, concebida como dotada da especialização necessária para esse fim. Afinal, como se aprende a trabalhar com índios? Como tal saber é transmitido? Em que práticas podemos vê-lo concentrado, já que não podemos achá-lo sistematizado sob a forma de manuais, tratados ou de uma escola de administradores coloniais? $\mathrm{Na}$ trilha da história do enquadramento jurídico dado aos povos indígenas pela administração colonial portuguesa, e depois pelas administrações imperial e republicana brasileiras, denominei de tutelar o exercício de poder de Estado que incide sobre espaços (geográficos, sociais, simbólicos), por meio da identificação, nominação e delimitação de segmentos sociais tomados como destituídos das capacidades plenas necessárias à vida cívica. Por esta sua "incapacidade relativa", ou por sua "hipossuficiência", como dizem os juristas, foram, pelo artigo $6^{\circ}$ do Código Civil Republicano de 1916, considerados carentes de uma proteção especial, juntamente com loucos, menores de 18 e maiores de 16 anos, mulheres casadas e pródigos. Em razão dessa tal insuficiência para a vida cívica, tornaram-se alvos de um tipo de 
mediação pedagógica, que viesse a lhes compensar a posição relativamente inferior em sua inserção na comunidade política e, supostamente, a torná-los preparados para exercer cidadania plena.

Porém, o exercício em si de tal poder conduz na direção oposta: numa certa dimensão, o ato de tutelar implica estabelecer vínculos próximos aos do clientelismo e da patronagem - à exceção de que aqui, menos que uma relação diádica e de matiz extremamente pessoalizado, o Estado como ideia, e por vezes como rede de agências interdependentes, é um fator interveniente fundamental, um terceiro elemento necessário ao estabelecimento desse vínculo de submissão/ proteção. Se o tutor tem como encargo instruir, ele age simultaneamente de modo a se eternizar na posição de fonte última de autoridade, da transmissão dos conhecimentos e modos corretos de vivenciar o pertencimento a uma comunidade mais abrangente. O pensamento do tutelado, suas ações, crenças, alternativas e capacidade de julgamento são permanentemente desautorizados em sua diferença, já que se considera que eles sejam construídos com base em um conhecimento imperfeito da realidade social em que se devem inserir.

Aqui fornecerei subsídios para pensarmos no espraiamento desse exercício de poder além da ação de uma agência específica dedicada ao governo dos índios. Contudo, a criação de um "órgão indigenista" (como se usa dizer) foi um ponto de inflexão fundamental, já que implicou o seu exercício rotinizado e organizacionalmente regulado nos planos jurídico e moral, ou, como João Pacheco de Oliveira (1988) o denominou, a instauração de um regime tutelar sobre os povos indígenas no Brasil (pensando-se, aí, mais do ângulo das várias situações históricas vividas pelos indígenas). Em tal exercício, a figura do Estado (presente ou ausente como rede de agências administrativas, não importa) é um termo imprescindível. A coletivização, a (relativa) laicização e a estatização do cuidado com os indígenas promovida nos primeiros anos do século XX pelo regime republicano no Brasil decantaram tradições de ordem colonial de distintas funções e origens, sedimentando-se numa trama de poderes e numa malha administrativa emergente, em que conhecimentos se articulam a - e são articulados por - práticas sociais incidentes sobre as ações e os modos de vida indígenas.

Criado em 1910, o Serviço de Proteção aos Índios (SPI) - que até 1918 tinha também a atribuição de Localização de Trabalhadores Nacionais, depois deslocada ao Serviço de Povoamento (Ramos, 2006) - encerrou nominalmente sua atribulada trajetória em 1967 (Souza Lima, 1995). Digo nominalmente, pois, no mesmo ano, foi criada a Fundação Nacional do Índio. Se esta não manteve continuidades estritas com o SPI, tampouco modificou radicalmente as ações de governo sobre os povos indígenas. E, mais importante para os fins deste texto, em nada alterou os padrões de relacionamento entre coletividades indígenas e o centro de poder do Estado nacional brasileiro. 
Geralmente, o termo tutela é usado como forma de denúncia, muitas vezes por lideranças indígenas, dos comportamentos do branco. Diz-se hoje que a tutela não acabou com o advento da Constituição de 1988 - descoberta um tanto óbvia, já que se as codificações jurídicas instauram realidades, não o fazem a curto prazo. Afirma-se também que "é preciso pensar a tutela para além do Estado" - como se algum dia ao espaço da administração governamental ela tivesse ficado restrita, ou dele emanasse, ao mesmo tempo desconhecendo o que de específico a ação estatal traz e a forma como muitas vezes funções de Estado são exercidas por organizações não governamentais, agências de cooperação internacional etc.

Mais importante mesmo é que nesse tipo de denúncia deixa-se de lado a parte do tutelado na relação, sua adesão e interesse em estar sob a patronagem de outro que o represente. Estar assim representado significa que, pela mediação e sob o controle parcial desse outro - um órgão governamental, uma organização não governamental (ONG), uma ordem missionária, cientistas de universidades coletividades como as indígenas e outras acessam recursos muito superiores aos que obteriam sem o tutor - o que é particularmente claro no caso de certos povos ligados a redes de relações muito assentadas dentro da Funai.

Esse esquecimento seletivo mais uma vez atribui ao branco todas as responsabilidades e, muitas vezes, delas isenta os indígenas, em razão de suposta ingenuidade e aparente desconhecimento das regras da vida na sociedade brasileira - um constructo imaginário, que para os dominantes é uma coisa e para os dominados outra, sejam lá quais forem as hierarquias e as formas de dominação em jogo. Tal situação vige mesmo quando as marcas percebidas como tutelares são fruto de escolhas bastante recentes na história do relacionamento entre coletividades indígenas, Estado nacional e redes sociais territorializadas, escolhas muitas vezes feitas com cálculo político, mais que premidas pela violência e pela ameaça à vida. Essa forma de conceber as relações entre indígenas e agências de governo é parte, pois, do repertório tutelar (de tutelados e tutores igualmente) e isenta, assim, os indígenas de qualquer responsabilização em compromissos e acordos clientelísticos bastante conscientes, traindo o quanto a perspectiva maternal que emana das formas tutelares está profundamente arraigada nas práticas de indígenas e não indígenas.

Este capítulo tem como base trabalhos anteriores sobre SPI (Souza Lima, 1995, 2009) e recupera um modelo histórico destinado a explicar como se delineou um exercício de poder de Estado sobre segmentos sociais que são tratados como coletivos e identificados por meio de processos administrativos como necessitados de uma proteção especial em razão de sua relativa incapacidade para a vida cívica - submetidos ou não a um regime tutelar mediante codificações jurídicas.

É importante destacar que, para se alcançar uma dimensão essencial da ação indigenista do Estado, não se pode ficar limitado apenas à escala local de análise, é preciso lidar sistematicamente com aspectos nacionais e até mesmo 
transnacionais. ${ }^{2}$ Ou seja, trabalhos focados num eixo tipicamente etnológico podem ser extremamente elucidativos de dimensões interacionais do exercício tutelar como modo de dominação, mas deixam escapar algumas das principais razões e meios pelos quais tal exercício se perpetua, isto é, aqueles que se reportam aos processos de formação de Estado. Contudo, cabe perguntar: o exercício de poder tutelar materializado num regime jurídico por códigos específicos é gerado e fixado apenas no espaço próprio das ações indigenistas estatais? Esse espaço foi sempre o mesmo? Tais perguntas conduzem a outra, sinalizada anteriormente: como profissionais de áreas tão diversas e aparentemente afastadas do espaço próprio do indigenismo aprendem rapidamente os códigos desse espaço e repetem a prática dos ditos órgãos indigenistas? Aliás, reproduzem seus aspectos negativos. Mas será exatamente isso que fazem?

Para subsidiar a reflexão sobre tais indagações, aqui recupero termos de processos mais amplos de transmissão de conhecimentos. Esses processos modelaram aspectos das práticas indigenistas atuais e, no presente, são (re)modelados por elas. ${ }^{3}$

É importante destacar que, embora este texto tenha, por vezes, um tom de indignação, minha preocupação aqui é conduzir uma reflexão empiricamente fundamentada sobre os mundos sociais em que se realizam as práticas indigenistas, tomadas como matéria de investigação científica e não de uma mera avaliação moral. Por vezes, posso enfatizar os aspectos de violência simbólica e os ostensivamente políticos - no sentido foucaultiano, em que a positividade dos exercícios do poder se afirma por meio da construção de realidades -, contudo não descuro dos sentimentos nem procedo a uma espécie de certificação das boas intenções.

\section{Para uma Abordagem Compreensiva da Prática Indigenista Tutelar: um modelo histórico}

Os poderes e saberes de ordem colonial que se condensaram em torno da prática indigenista no início do século XX, institucionalizando-se no SPI, em 1910, têm origens históricas distintas, conquanto coetâneas. É indiscutível, porém, que têm como ponto de partida a invasão europeia das terras de povos indígenas das Américas. Para fins de estabelecer o esboço de uma genealogia dos poderes que se articulam desde então, remeto a reflexão sobre tais poderes e saberes à empresa da guerra de conquista - ou, simplesmente, a conquista. É importante destacar que o que se poderia chamar de narrativa da conquista, com seu aspecto cruento e genocida, foi pouquíssimo acionado no caso da construção da história do Brasil.

O tópos da descoberta do continente americano assola ainda hoje em larga medida a historiografia brasileira. Juntem-se a isso os vários estereótipos 
sobre os ocupantes dessas terras aqui encontrados pelos europeus, em especial os que reduzem complexas formas políticas a uma reflexão sobre o seu caráter (não) (anti)estatal dos povos indígenas - os "sem fé, nem lei, nem rei" dessa porção das Américas. Apesar da estranheza dos sacrifícios humanos e de outros costumes dos mundos indígenas andinos e mesoamericanos, passíveis de serem equacionados à forma política império, dotados, portanto, de poderes centralizados e passíveis de serem conquistados numa única empresa organizada a eles dirigida, as invasões e conquistas dos povos e de seus territórios que ocupam o que é atualmente o Brasil foram inúmeras e são empreendidas até o presente.

A construção analítica de um exercício de poder tutelar partiu das indagações de Michel Foucault relativas às formas de individualização e assujeitamento que se governamentalizam progressivamente com a formação dos Estados modernos, contribuindo decisivamente para sua formação. Esse autor propôs tomar como metas para a investigação genealógica indagar-se sobre o exercício do poder: seus mecanismos, efeitos, relações e técnicas (ou tecnologias), em suma, o como do poder (Foucault, 1983). Concebendo as relações de poder como ações sobre ações, distinguindo-as, portanto, das relações de violência que atingiriam coercitivamente os corpos, Foucault (1997) sugeriu pensar o poder em termos de combate, reportando a política à guerra, como seu prolongamento por outros meios numa inversão. Retirou daí três implicações especialmente significativas para a construção da ideia de poder tutelar. A primeira é a de que as relações de poder atuais remontam historicamente à guerra, e que o poder político, ao se fazer a paz, reatualiza a guerra de diferentes modos. A segunda constatação é a de que, consequentemente, devem-se interpretar as lutas políticas como formas de continuidade e de deslocamento da guerra. Por último, o autor sugere que a guerra deve ser o último juiz do conflito.

A utilidade dessas concepções para a reflexão sobre o relacionamento entre populações nativas e colonizadores é grande, sobretudo quando se consideram os múltiplos processos de aniquilamento, submissão, aliança e recomposição desses povos no caso das possessões portuguesas na América. A afirmativa é válida desde os primeiros contatos com as variadas formas de domínio comercial lusitano, até os mais recentes períodos de expansão nacional sobre o território.

Nessa perspectiva, a guerra não é vista aqui somente como forma de destruição e catástrofe, mas como via constitutiva de novas relações sociais, base de múltiplos sistemas de aliança e antagonismo. Trata-se, pois, de ultrapassar o binômio destruição/resistência, muitas vezes subjacente aos intentos que se filiam à ideia de uma história dos vencidos abandonando as narrativas de feitos heroicos das partes em confronto. No entanto, se toda guerra necessita de augúrios e informação, a guerra de conquista, ao envolver um grau de alteridade muito mais radical, faz-se possível, sobretudo por procedimentos interpretativos, teatrais e improvisatórios (Todorov, 1988). O conquistador deve desenvolver processos de 
observação e atribuição de sentidos por analogias construídas com base em estoques de conhecimentos anteriores ao enfrentamento com a alteridade.

A conquista supõe certa disposição de linhas de força entre um eu/nós e um outro, podendo oscilar das relações de violência às relações de poder (Foucault, 1983), caracterizando-se como guerra, sobretudo pelas primeiras. Todavia, também implica uma dada forma de busca de sentidos nos atos alheios, tarefa essencialmente semiótica. Esforços desse gênero envolvem uma grande e necessária agilidade ante o desconhecido humano para dar as respostas adequadas à obtenção dos fins pretendidos, ainda que fora do estoque simbólico oriundo do conquistador, se necessário encenando aquilo em que não se acredita. Quero dizer que a própria consciência da alteridade, e a capacidade de utilizá-la instrumentalmente para prever os passos e manipular o inimigo, são tanto os pontos de partida fundamentais quanto os operadores da conquista. Distingue-se, destarte, nos termos de Todorov (1988), da descoberta, termo que designa uma configuração de atos que se dirige à natureza, a espaços desconhecidos, onde o encontro entre seres humanos não é o centro mesmo da empresa.

Se não há violência quando relações de poder estão em jogo, os processos atualizados na guerra podem se transformar para permanecer, compondo diferentes aspectos presentes na conquista: um outro humano que é desconhecido em maior ou menor grau, associado a um espaço geográfico que se pretende ocupar; uma organização militar (dentre a qual devem ser incluídos os especialistas no deslinde/ atribuição de significações inauditas) com uma direção centralizada (de diferentes modos) a definir e representar a unidade da empresa, muitas vezes parcialmente fictícia; o(s) povo(s) de origem da organização. Formulando de outro modo: 1) a organização militar conquistadora encimada imaginariamente por uma realeza, um império ou constructos, como Deus, a nação etc., e nos seus desdobramentos por um corpo que se chamará de administrativo com funções integrativas e de imaginação social; 2) o povo do qual se origina, entendendo-se por tanto o conjunto de unidades sociais sujeitas (de diferentes modos e com distintos graus de dependência) a uma direção comum e se reconhecendo uma identidade social comum, ainda que superposta a outras múltiplas identidades distintivas; 3) o butim, composto pelo povo propriamente conquistado, transformado em cativo, suas terras e suas riquezas, os quais, no caso da conquista, são mercantilizados por meio da guerra em seu primeiro momento, sendo lançados em circuitos comerciais de grande amplitude.

Numa etapa posterior, o butim vem a se compor, por meio de múltiplos modos de exercício do poder e da dominação (da presença de uma administração, portanto), em matéria para variadas e estáveis formas de tráfico e comércio. A dimensão econômica da conquista deve, pois, ser destacada, diferenciando-a nos planos político, social e imaginário de seu momento seguinte: a guerra de conquista dá lucros a seus participantes quer na qualidade de integrantes da organização militar 
realizadora da tarefa guerreira, quer na de parte de um corpo administrativo que age de modo mais amplo, inclusive nas suas variadas formas de delegação de poderes a grupos privados.

O vínculo interativo de aliança, base das futuras estruturas de domínio envolvendo os povos invadidos, é elemento básico desse constructo formal, sendo importante ressaltar que a existência de três estratos - organização administrativa conquistadora/povo conquistador/povos aliados ao conquistador - detona possibilidades relacionais passíveis de serem apropriadas com base na ideia da tríade, como apresentada por Georg Simmel (1964): num jogo entre os três termos, no qual o objeto que se disputa é o butim, passa-se muito do que será a matéria de distintas articulações de poder, passíveis de serem descritas para casos concretos por meio da noção de situação histórica. O exercício do poder tutelar encontraria interessantes matizes quando remetido a esse quadro formal da interação triangular: mediar sem tomar partido em disputas, dessa maneira acumulando poder; arbitrá-las, decidindo-se por uma das partes; utilizar-se do conflito em proveito próprio ou, para usar a expressão romana, divide et impera (Simmel, 1964), intencionalmente produzindo o dissenso, são algumas das possibilidades interativas por meio das quais se pode interpretar parte de seus modos de exercício em análises de relacionamentos historicamente singularizados.

\section{Administração e Engendramento de Comunidades Políticas Nacionais}

Partindo dos elementos formais apresentados como um modelo da empresa da conquista, pode-se indagar que formas de articulação social e de ação política coletivas surgem, pois, da invasão e do confronto entre conquistador e conquistados. Pode-se então pensar: quais as continuidades e distanciamentos dados a cada novo povo indígena pacificado? O que é o índio, termo apropriado para designar um status social, matéria de incidência de um conjunto de práticas de governo? Perguntas muito abrangentes e informes, aparentemente simplórias, nem por isso não formuláveis. Sua resposta não pode ser genérica e única, apenas no plano do modelo, como aqui estou trabalhando. Contudo, tais perguntas adquirem outros sentidos ao se reconhecer que toda conquista envolve a subsequente administração do butim, processo capaz de produzir homogeneidades que eram inexistentes antes de sua intervenção - de terras indivisas, ou sujeitas a outros padrões de delimitação, criam-se territórios, produz-se uma população capaz de se reconhecer como uma comunidade (como objeto de controle racional por agências administrativas) onde antes apenas existiam povos dispersos, histórica, linguística e culturalmente distintos. Benedict Anderson (1991), referenciado especialmente aos casos hispano- 
americanos, articula a constituição de impérios mundiais e a emergência de nacionalismos nas Américas, prévios até mesmo ao seu surgimento na Europa, remetendo tais fenômenos à administração externa e às formas de exercício da soberania sob - Estado monárquico moderno. Interrogando-se sobre as razões dessa anterioridade americana do que chama de nation-ness (traduzido por consciência nacional), Anderson começa por sinalizar o fato de as assim chamadas colônias no continente americano terem se constituído em unidades administrativas entre os séculos XVI e XVIII. Propõe que se investigue o modo como as organizações administrativas atuam criando significados, na busca de entender como foram imaginadas comunidades políticas (pátrias) onde na verdade se tinha uma dispersão de unidades administrativas.

Tal indagação é fundamental para minha proposta. Anderson começa a responder a ela utilizando as reflexões de Victor Turner (1974) acerca do papel das peregrinações e viagens de caráter religioso na criação de sentimentos comunitários. Desloca tais ideias da órbita das comunidades religiosas para a dos sentimentos comunitários surgidos com o hiato entre a corte e as distintas colônias em impérios transcontinentais, o que impunha frequentes viagens pelas necessidades da administração.

Sob a égide do poder soberano, o impulso básico, no nível europeu, era controlar a dispersa e autônoma nobreza feudal por meio de aparelhos unificados em torno do monarca absoluto. A corte passava a ter, assim, um papel de centralidade que contrastava com a circulação de funcionários cujo poder era dependente da vontade do soberano, numa administração patrimonial altamente estratificada. Considerando que os movimentos de independência nas Américas partiram de grupos sociais crioulos - quer os surgidos como fruto de casamentos entre conquistadores e povos indígenas (ou as africanas transplantadas), quer os que pelo simples nascimento nas colônias das Américas, embora de pais europeus, tinham outro status -, Anderson sugere como esses futuros estratos dominantes no pós-independência caminhariam para redefinir os indígenas e outras populações de status inferior, oriundas da fixação de componentes do povo conquistador, como parte de uma comunidade nacional, sem implicar o acesso aos mesmos direitos de participação política. Estabelecia-se assim um gradiente de pertencimento que começava nas cortes metropolitanas e terminava nos povos indígenas das Américas, onde todo um sistema de privilégios e exploração, largamente assente sobre o gênero e a diferença fenotípica, determinava as possibilidades de ascensão na hierarquia social dos impérios transcontinentais.

Anderson dá ênfase ainda a formas de circulação da informação para criar uma comunidade de significados, como seria o efeito da imprensa diária dos inícios do século XIX em diante. A administração permitiria, assim, pelo seu peso sob os regimes de soberania, ao limitar e excluir o acesso ao soberano e sua corte, que 
os estratos por ela distinguidos se reconhecessem como partícipes de uma comunidade imaginada (Anderson, 1991). A administração tem, pois, um significado determinante, embora não único, nos processos de formação de estados nacionais, mormente em territórios conquistados. Dentre os diversos aparelhos de poder, os de caráter militar são básicos, e seu formato seria matéria para indagação específica, pois como sinaliza Charles Tilly (1975: 52), "war is the characteristic condition, and armed force the characteristic instrument, of the state system". ${ }^{4} \mathrm{E}$ a força militar que territorializa, pela sua fixação em unidades administrativas, impondo um controle centralizado a redes sociais a serem compostas em uma única comunidade política, ao mesmo tempo distinguindo-a de outras. Foucault (1977) destaca que se do século XVIII em diante há um sonho jurídico de uma sociedade contratualista, há também em paralelo um sonho militar de uma sociedade disciplinar que tem sido negligenciado no plano da análise histórico-política.

Com a ideia de poder tutelar, busquei descrever formas de ação que - se nem sempre estatais em sua origem histórica - num dado momento se concentraram sob o comando dos especialistas em imaginação de coletividades e de sua administração, num centro social e geográfico de poder imaginado como nacional. Tal exercício de poder estatizado sobre as ações e os territórios dos povos indígenas no plano histórico origina-se, em primeira instância, nas conquistas portuguesas e sua administração - guardando continuidades implícitas com elas por dispositivos de poder que visavam a assegurar a soberania do monarca lusitano sobre territórios dispostos em variados continentes, com um equipamento material e recursos humanos bastante reduzidos.

Dito de outro modo, trata-se de sedentarizar povos errantes, vencendo mediante ações sobre suas ações e não no uso da violência física - sua resistência em se fixarem em lugares definidos pela administração, ou de capturar para essa rede de agências de governo outros povos com longo tempo de interação com o conquistador, operando para tanto com a ideia de um mapa nacional. Sobre este se disporiam as diversas unidades de ação da agência tutelar, cuja maior ou menor amplitude geográfica de gestão repercutiria na mesma proporção em peso funcional: à maior restrição de âmbito caberia um suposto menor poder de decisão definido por normas operacionais internas à agência. Como nas sociedades de soberania, tal forma de poder incide sobre espaços, estabelecendo-lhes limites muitas vezes com o emprego de processos fundamentalmente de exibição e teatralização. Criam-se, assim, territórios por meio da administração, cuja mera existência acaba por justificar a função de administrá-los. Contudo, isso é feito excluindo/incluindo populações na esfera de controle administrativo, às quais são atribuídas posições sociais específicas, isto é, status diferenciados. O exercício do poder tutelar implica obter o monopólio dos atos de definir e controlar o que seja a população sobre a qual incidirá esse poder. 
Pode-se parafrasear Foucault quando ele compara os modelos de exclusão suscitados pela lepra e os esquemas disciplinares engendrados a partir da peste: o poder tutelar exclui ao criar postos indígenas aos quais os povos nativos deveriam (re/a)correr e junto aos quais deveriam se agregar e segregar. Ao mesmo tempo, porém, inclui contingentes populacionais e terras numa rede nacional de vigilância e controle disposta a partir de um centro de poder. O termo posto palavra cujos variados significados evocam as ideias de sistema hierárquico e de ação militar - usado para as unidades de ação locais da agência de governo dos índios, designava um dispositivo de poder cuja ação deveria gerar, pelo tratamento supostamente segregado das populações às quais se destinava a atender, porções separadas do espaço interior estabelecido pelos limites internacionais do Estado nacional brasileiro.

Para a administração, o importante é rotular genericamente populações e inseri-las num sistema codificado de atribuições positivas e negativas - um status, portanto -, parte de um mecanismo imaginado como de governo nacional. O primeiro instrumento legal a regular essa função de identificação e hierarquização espacializada foi gerado pelo conjunto de atores que implantou o SPI e se transformou na lei n. 5.484/1928 (Souza Lima, 2009), que teve como fim regular, legitimar e universalizar a própria administração tutelar não só dos povos indígenas sobre as quais incidia diretamente, mas também, sobretudo, das redes sociais locais autônomas em relação aos (tíbios) poderes federais. Tal dimensão é de significativa importância, pois, se a literatura especializada tem apontado a relação entre Estado nacional e expansão da cidadania - notadamente nos aspectos de um acesso mais amplo por parte de certas classes e frações de classe aos direitos civis e sociais, e uma suposta maior participação política -, a forma como foi concebido o pertencimento dos povos indígenas à comunidade política brasileira apontava em direção muito distinta e oposta. Para os indígenas, a possibilidade de ter acesso a direitos básicos, como o do reconhecimento das terras por eles ocupadas, e a uma assistência diferenciada passava por serem definidos como hipossuficientes, em termos jurídicos estritos, para o exercício de numerosos atos da vida civil, fazendo-se necessária a presença de uma agência de governo estatizada que os representasse politicamente.

O melhor produto da dinâmica tutelar foi, talvez, a figura das reservas indígenas, isto é, porções de terra reconhecidas pela administração pública por meio de suas diversas agências como sendo de posse de índios e atribuídas, por meios jurídicos, ao estabelecimento e à manutenção de povos indígenas específicos. Sob a gestão do SPI, e até tempos muito recentes, também da Funai, as reservas (depois terras) indígenas foram definidas à custa de processos de alienação de dinâmicas internas às coletividades indígenas e passaram a compor parte de um sistema progressivamente estatizado de controle e apropriação fundiária que se procurou construir como de abrangência nacional. Sua finalidade era disciplinar o 
acesso e a utilização das terras, ao mesmo tempo mediando sua mercantilização, aplicando sistemas de registro e cadastramento (procedimento que não se impôs sem conflitos entre as numerosas agências de governo) nas diversas unidades sociais surgidas historicamente da(s) conquista(s). As reservas foram também modos de concentrar e estatizar riquezas (terras para agricultura, pecuária e extração de minerais, florestas para o extrativismo de madeiras, borracha, castanha etc.) que a administração tutelar manteve para exploração direta ou indireta (por exemplo, pelo arrendamento) sempre em suposto benefício dos indígenas e utilizando de forma muitas vezes servil seu trabalho.

O exercício do poder tutelar implicou também um trabalho de semiotização, mas de diferente ordem daquele atualizado na guerra de conquista. Até fins do século XIX, falava-se em civilizar os índios e não havia dúvidas quanto a quem seria destinado esse trabalho civilizatório. Se era fácil reconhecer a diferença entre índios e não índios, não era porque os povos indígenas não fossem matéria de produção etnográfica ou legal e de opiniões contraditórias, mas sim porque não existia uma agência de governo voltada especificamente para o exercício tutelar, que, ao operar incidindo sobre uns e deixando de fora outros, criava bases objetivas para atribuir a qualidade de ser índio. Com a criação de uma agência como o SPI, a administração pública passou a definir, mais na prática do que no direito, quem é e quem não é indígena, quem pode ou não receber os serviços do Estado, a tutela num momento, a proteção diferenciada em outro.

Os especialistas da significação da era das nações e da era da globalização (antropólogos, sertanistas, indigenistas, missionários notadamente, e também - por que não? - os profissionais da saúde diferenciada, da educação diferenciada, do desenvolvimento diferenciado etc.) não são somente aqueles que, em processos de pacificação, refazem, de forma não violenta, o percurso dos conquistadores, enquadrando-se na categoria dos que fazem do entendimento e da tradução da alteridade sociocultural a matéria ou ferramenta de seu trabalho. Entender o outro passou a ser também apresentá-lo e relacioná-lo à comunidade nacional, definindo-o, delimitando seu espaço de circulação (social e geográfico) possível, inserindo-o, pois, na esfera da memória, resolvendo de certo modo, nesse plano, o problema dos limites e da forma de seu pertencimento à nação. A posição institucional desses especialistas pode variar, mas é impossível desconhecer que eles mantêm com a agência de poder tutelar relações complexas, quer dela participando, quer a ela se aliando ou se opondo. É também importante ter em mente que tal inserção se dá não apenas na forma de assimilação, mas também está presente sob o ângulo dos direitos diferenciados. Afinal, após a Constituição de 1988, com frequência os diferentes continuam sendo pouco ou nada consultados pelas agências de governo hoje encarregadas de políticas diferenciadas. Na área das ações para a saúde dos povos indígenas, a especialização foi rapidamente surgindo. 
Em meu trabalho (Souza Lima, 1995), tomei como centro da tarefa etnográfica a interpretação do plano organizacional e os modos de operação das agências encarregadas do exercício cotidiano do poder tutelar. Se optei por tal ponto de partida foi por considerá-lo como a dimensão necessária, pouco investigada como expressiva de um pensamento de Estado, mais facilmente atingível pela pesquisa histórica não restrita a um caso específico. Os grandes vultos do pensamento social brasileiro, distinguíveis com facilidade para cada área das ações governamentais, são facilmente mapeáveis. Entretanto, como pensam e agem os funcionários que lidam diretamente com os sujeitos às ações estatais? Como essas ações são infletidas pelos seus destinatários? Que esquemas mentais portam tais atores que lhes permita agir e - quiçá! - repensar na prática sua ineficácia? Suponho, portanto, que não haja um descompasso radical entre esquemas de ação e esquemas de pensamento e que descrever agências de governo é também simultaneamente descrever ideias e práticas.

As formas simbólicas, como veiculadas em planos estratégicos de agências de governo e em suas traduções regionais e locais, as instruções e as normas de funcionamento das agências governamentais têm força própria, como pretendentes à universalidade e à racionalização, para além do fato de terem sido ou não postas em prática e do modo como foram implementadas. Avaliar ou mensurar uma suposta eficácia do SPI não nos conduz a entender suas práticas cotidianas. Julgar seus méritos e erros mediante padrões morais ou qualquer outra perspectiva valorativa, típica das denúncias, e, por vezes, contida nas avaliações de políticas, não nos leva a entender seu legado nem pertinência. Creio que o mesmo possa ser dito de qualquer agência governamental - ou, mais amplamente, das práticas de governo em seus variados matizes. O parâmetro utilizado para estabelecer a medida da eficácia, com frequência, foi a capacidade da agência de preservar ou não a vida dos povos indígenas no que se refere à existência biológica e a evitar massacres e epidemias. Criou-se, aí, a ideia de que intervenções emergenciais e salvadoras configuravam o cerne da vida da instituição. ${ }^{5}$ Não importa que na sua ação cotidiana a agência fosse etnocida, isto é, operasse com o objetivo de aniquilar a diferença cultural que justificava a existência mesmo de tal administração: salvar vidas (tal como a administração concebia a vida, no sentido da manutenção da integridade física de indivíduos biológicos, bem entendido) era o que lhe atribuía o mais alto valor e até mesmo as tintas de heroísmo.

O que aqui chamo de agência tutelar existe há um século, com as descontinuidades que qualquer análise sobre a Funai poderá pôr em confronto com as do SPI. É tempo considerável para, se analisado do ponto de vista de efetivas ações para os nativos, algo ineficaz - como a Funai tem sido chamada - permanecer. Afinal, a inércia - uma inércia febril, de fato, característica de toda burocracia - encobre o caráter autorreprodutivo e o esforço em permanecer das estruturas de poder mais 
amplas que a agência alicerça se alicerçando, movimento no qual a configuração da administração pública tem sua parte, e que uma análise histórica poderia ajudar a esclarecer para muitas outras áreas do sistema de agências de Estado. Mudá-las não implica alterações necessariamente grandiosas ou panaceias políticas, como as muitas reformas administrativas que vêm sendo anunciadas desde o início do regime republicano no Brasil, mas requer um primeiro trabalho de desvendamento de suas bases político-simbólicas, o esteio dessa suposta inércia e da capacidade de disseminação desses conhecimentos. Afinal, inexiste um processo específico de treinamento e transmissão de conhecimentos que sustente a manutenção de certas práticas no trabalho direto com os povos.

\section{Tradições Coloniais para Gestão e Perpetuação da Desigualdade Social}

Até aqui procurei (re)construir, como um modelo, a trajetória do que chamei de poder tutelar, construindo-o com base em elementos que articulam os exercícios de poder sobre os povos indígenas com a invasão e a conquista do território americano, para depois situá-los nos processo de formação de Estado e construção da nação. Parece-me agora importante sinalizar a forma como os conhecimentos gerados na guerra de conquista e na colonização do território brasileiro se desdobram no tempo, partem de estoques simbólicos mais amplos, perpetuam-se e se presentificam. Tal raciocínio implica ter em mente como os Estados nacionais em especial o brasileiro -, por meio de seus quadros administrativos, produzem, transmitem, reproduzem e se apresentam internamente especializados quanto ao conhecimento destinado à gestão de espaços e populações. ${ }^{6}$

Não penso que a ideia de tutela implementada pelo regime republicano seja estritamente a mesma que a do período imperial ou colonial, nem sugiro que as práticas tutelares ainda vigentes tenham uma continuidade estrita com as ações das agências indigenistas. Quero, todavia, enfatizar que a prática efetiva das políticas de governo para os indígenas - dentre elas as da saúde indígena - não pode ser adequadamente explicada sem o recurso a uma antropologia histórica que, lidando com o tempo presente, o faça considerando a longa duração.

É indiscutível a importância de se entenderem os modos pelos quais os conhecimentos implícitos na ação tutelar de agentes governamentais são reapropriados e ressignificados pelos povos indígenas ou outros segmentos populacionais. Apenas com base em pesquisas que contemplem tais modos de conhecer é que se podem aferir as possibilidades de mudanças desses estoques de saberes mais amplos que norteiam as ações governamentais na escala local. Para 
compreender como as coletividades indígenas apreendem a percepção que delas têm os agentes dos poderes estatais, é preciso que seus conhecimentos acerca dos colonizadores sejam postos efetivamente em relação com os saberes aportados pelos agentes coloniais com que lidam, com a cadeia de autoridades com que tais agentes mantêm relações de interdependência que os articulam aos centros de poder. ${ }^{7}$

Cada ator envolvido nas políticas indigenistas, ao chegar a uma coletividade indígena, depara-se não apenas com as cosmologias e tradições culturais, imprescindíveis a certas investigações, mas também com a história de seu relacionamento com a sociedade local e regional, bem como com os poderes de Estado, que se fazem presentes por meio de suas agências. Toda relação armazena história (Tilly, 2000), e é necessário trazê-la à tona, como propõe Pierre Bourdieu (1989), para que não sejamos herdados por nossa herança. Esse "trabalho morto simbólico", que usualmente não é considerado nos planejamentos e ações governamentais, estrutura repertórios de práticas que acabam dando o verdadeiro sentido das ações de governo no plano da vida cotidiana, o que acaba por mostrar o quanto o modelo racionalista de operação de políticas públicas é insuficiente para explicar o funcionamento concreto da máquina estatal. ${ }^{8}$

Para entender o descolamento entre as intenções e os gestos, ou entre os planos e sua execução, é imprescindível conhecer a história incorporada em disposições para a ação, em posturas físicas, em expedientes retóricos, e objetificada em agências, em códigos e em planos escritos, entendendo assim a genealogia dos poderes de Estado que afetaram (nesse caso) as coletividades indígenas por longo tempo, e hoje são ainda largamente desconhecidos pela antropologia e pela historiografia no Brasil, sem falar na ciência política, que alicerça as análises de políticas públicas. Em geral, os profissionais da saúde, quando, em sua formação, têm acesso a algum estudo sobre políticas de saúde, tomam contato com o modelo racionalista de análise de políticas públicas. É comum que essa perspectiva racionalista se torne uma verdadeira camisa de força para o agente que concretamente tem de intervir em campo.

Tal situação é tanto mais grave quando pensamos naqueles agentes que vêm trabalhando com saúde indígena. Quando tiveram acesso aos estudos de políticas de saúde, o fizeram de acordo com o modelo racionalista clássico de análise das políticas públicas - diagnóstico e identificação de um problema, estabelecimento de uma agenda, formulação de um plano de intervenção, implementação do plano, avaliação, revisão, etapas sempre desejadas e quase nunca cumpridas - e nada puderam entender das motivações que conduziram múltiplos agentes a convergirem na ideia de um Subsistema de Saúde Indígena. Se não conseguem entender o subsistema em que estão inseridos, menos ainda são preparados para compreender as coletividades indígenas com que trabalham cotidianamente. Alguns mais sensíveis reclamam da falta de formação em antropologia que lhes permita acessar as 
concepções dos povos com que lidam. Mas não creio que qualquer análise que se centre nas concepções cosmológicas indígenas, ou em como a partir delas esses povos pensam as ações governamentais que sobre eles incidem, seja suficiente para explicar seu comportamento para fins práticos. Tampouco creio que uma descrição limitada ao âmbito local ou regional das intervenções governamentais possa prescindir do entendimento dessa história de longo prazo presente, reelaborada, na vida cotidiana hoje.

Para entender a interação entre indígenas e agentes de governo no plano local é preciso reconhecer que os especialistas no exercício cotidiano das formas de dominação - os agentes diretos das políticas governamentais, tenham eles a formação escolar que tiverem - são produtores e transmissores de saberes que em si têm uma história própria, e devem ser objeto de investigações genealógicas, assim como de estudos de antropologia e de sociologia históricas. Considerar os saberes em estado prático que norteiam as ações cotidianas de agentes governamentais implica reconhecer a necessidade de, ao menos, dois movimentos primários no plano analítico-interpretativo: 1) religar os estudos sobre formação de Estado no Brasil (e, de modo mais amplo, o das formas político-culturais) aos sobre a história portuguesa, mais especificamente à história do seu Império colonial, tomando o âmbito lusófono como universo de referência e comparação privilegiado; 2) tratar certos poderes e políticas de Estados nacionais como resultantes dos processos de colonização europeia, remetendo-os ao efeito de instituição da desigualdade presente nas "situações coloniais" (Balandier, 1951), de modo que lhes fosse restituída a profundidade histórica de sua estruturação, capaz de explicar a grande dificuldade em transformá-los. Tais movimentos nos dariam uma perspectiva temporal mais abrangente, assim como possibilidades de crítica social mais amplas.

Um caminho seria tentar definir uma única cultura do colonialismo português, colocando-se o Brasil como suposto herdeiro desse legado - presente na sociedade brasileira no amplo domínio das relações pessoais, em determinados aspectos de certa informalidade e concisão jurídica etc. - , e desta totalidade deduzir numerosos aspectos da realidade brasileira contemporânea. Outra forma seria compreender como certas categorias socioprofissionais específicas, responsáveis pela gestão de distintos aspectos do empreendimento imperial, em diferentes momentos do tempo e em interações com as realidades locais preexistentes à sua intervenção, produziram, geriram e transmitiram seus conhecimentos. É à pluralidade e complexidade dos saberes e dos poderes desses especialistas que seria oportuno dirigir um conjunto de perguntas, movimento interpretativo a ser associado a outros que incidam tanto sobre os povos com os quais atuam quanto sobre as agências a que pertencem em sua atualidade. Uma via possível para isso seria uma utilização descritiva e formal das propostas de Fredrik Barth (2000) para a abordagem dos fenômenos culturais, que, na tentativa de ultrapassar os efeitos 
homogeneizadores e redutores da complexidade que um conceito (holístico) de cultura pode carregar, propõe que se pense em termos de correntes de tradições culturais, de modo a tornar possível a busca da coerência simultaneamente ao reconhecimento do pluralismo cultural. ${ }^{9}$

Fazendo uso um tanto deslocado daquele proposto por Barth, mas procurando guardar algumas de suas principais chaves de interpretação, proponho utilizar o conceito de tradições de conhecimento para refletir acerca dos vínculos entre empresa imperial portuguesa e os Estados surgidos em regiões onde esta operou. Sem supor uma continuidade histórica estrita, quero destacar como certos modos de ação se fazem presentes ainda hoje transmutados, nas práticas cotidianas de agentes governamentais, atualizando funções e posturas coloniais ante as coletividades indígenas e outras ditas populações tradicionais, ou mesmo diante dos ditos pobres. São, pois, tradições de gestão de populações e de intervenções sobre espaços, que estocam saberes/fazeres usados na empresa colonial europeia.

Uma tradição de conhecimento para gestão colonial, nesse caso, poderia ser pensada como um conjunto de saberes quer incorporados e reproduzidos em padrões costumeiros de interação em etiquetas, disposições corporais, gestos estereotipados, ritos da vida cotidiana, quer objetivados em dispositivos de poder na forma de codificações legais, de textos escritos que teorizam as tarefas da conquista e colonização, elementos materiais de cultura (arquitetura, indumentária etc.).10 Descobrir e disseminar informações, submeter e definir, classificar e hierarquizar, aglutinar e localizar os povos conquistados e os espaços por eles habitados são operações desenvolvidas pelo que chamo de saberes de gestão e pelos poderes pelos quais tais conhecimentos se exercem e se perpetuam. Os saberes/fazeres que podemos agrupar em tais tradições voltam-se para a produção e a manutenção da desigualdade entre colonizador e colonizado, pautando-se pela busca de exploração e expropriação dos recursos dos colonizados, pela instauração de assimetrias baseadas na diferença fenotípica, estética e de gênero. Sugiro, pois, que os poderes de gestão de populações em contextos coloniais definem simultaneamente espaços sociais e geográficos, criando-se, por vezes, verdadeiros territórios entretecidos a hierarquias sociais, que acabam codificadas em direitos.

Os conhecimentos que proponho tratar a partir dessa ideia operam desqualificando outros saberes que não os do colonizador; conduzem à objetificação do colonizado, tornando-o escravo, muitas vezes retirando-lhe a condição de humano; buscam transformar radicalmente as visões de mundo dos colonizados, tarefa mediada por agentes especializados em conduzi-los a deixarem seus modos de ser. Em última instância, são conhecimentos pautados nas práticas de geração de lucro mediante a exploração direta dos colonizados, de seus territórios e de seus recursos de toda ordem. É importante notar, porém, que tais formas de conhecimento incidem também sobre os povos e organizações que conquistam e 
colonizam novos espaços geográficos e seus habitantes, num necessário e transformador efeito de retorno.

Mesmo quando aparentemente voltado para uma integração crescente entre povos conquistador e conquistado, o trabalho de gestão colonial perpetua a desigualdade de capacidade de realização, de mando e de ver seu mando obedecido, assegurando o domínio do colonizador. Quando protegem a diferença cultural para permitir a continuidade dos modos e estilos de vida que nela se baseariam, como em uma espécie de estado in vitro, os saberes e poderes postos em jogo pelos colonizadores numa situação colonial exacerbam e criam a necessidade de mediação para que os colonizados possam acessar as formas sociais que lhes são impostas como dominantes. Quando aproximam as diferenças entre as tradições de colonizadores e colonizados, na busca de maior integração social, amesquinham as correntes culturais dos povos colonizados, circunscrevendo-as, delas se apropriando, objetificando e exotizando o cotidiano dos povos que dominam. Em ambos os casos, reproduzem a desigualdade social. No entanto, as experiências coloniais afetam também e em larga escala as cosmologias, os modos de viver, sentir e pensar sobre a natureza e as coletividades humanas dos povos colonizadores, largamente por meio de suas organizações administrativas, com isso suscitando críticas e insurgências e redefinindo seus próprios mapas mentais.

Pensando com base no caso brasileiro, em especial no exercício dos poderes de Estado sobre as populações indígenas, e tendo como horizonte de reflexão o contexto colonial, poder-se-ia distinguir quatro grandes tradições de conhecimento para gestão colonial da desigualdade entre os povos indígenas e os africanos transplantados, além dos contingentes populacionais que aqui surgiram. Elaborando-as como tipos ideais para pensá-las, pode-se denominá-las de tradição sertanista, tradição missionária, tradição mercantilista e tradição escravista.

Por tradição sertanista entendo um conjunto de saberes que, alterando-se ao longo do tempo, podem ser reportados ao início da exploração portuguesa de África, notadamente à dos espaços afastados do litoral, os chamados, desde o século XV e já em África, sertões. Explorar e registrar os contornos de espaços geográficos incógnitos, inserindo-os no mapa mental e nas cartas geográficas como partes do mundo conhecido pelo explorador, gerando assim conhecimentos com frequência de valor estratégico no plano geopolítico e econômico; avaliá-los como fontes para exploração comercial sem, no entanto, esboçar uma descrição das populações humanas nativas desses espaços, mantendo com elas contatos e trocas iniciais, muitas vezes estabelecendo algumas das primeiras operações de uma guerra de conquista, são apenas algumas das ações características da tradição sertanista. No caso brasileiro, no contexto da proteção oficial aos índios, logo no século XX, o termo sertanista designa o especialista nas técnicas de atração e pacificação (Souza Lima, 1995) de índios ainda arredios à interação regular com as agências de governo, fossem hostis ou não. ${ }^{11}$ 
Por tradição missionária é possível designar o conjunto de saberes que tem na Igreja católica seu ponto de dispersão, e no cristianismo em geral sua referência básica, sobretudo por meio do dispositivo da conversão e das técnicas de pastorado. ${ }^{12}$ Era necessário entender os usos e costumes dos povos gentios para explicar e impor os modos de ser e agir europeus, não apenas produzindo aliados e mão de obra, mas transformando pagãos em catecúmenos. Tratava-se, pois, de assegurar que porções cada vez mais significativas das realidades construídas pelo colonizador adquirissem o automatismo dos efeitos de verdade, que estes fossem incorporados e, por vezes, mediante negociações variadas, sincretizados com correntes culturais dos colonizados.

A visão de mundo do conquistador, presidida pela ideia de missão salvadora emanada de Deus por meio da ação dos monarcas de impérios transcontinentais, faz-se presente em estado incorporado em valores, disposições para a ação, em modos de percepção e interação, disposições corporais, formas de sentir e se expressar. Objetivada em crenças disseminadas e submetidas a dispositivos de controle social, em instituições, códigos, tecnologias, monumentos e narrativas que passam a construir e constituir a história dos que nela se reconhecem, tal visão aparenta desconhecer as singularidades dos povos sobre que incidia, ainda que na prática isso fosse impossível: não há dominação que se configure como imposição total, sem insurgências. As elites crioulas são um particular exemplo do triunfo da tradição missionária.

Também a tradição missionária delimita lugares para sua ação (missões, aldeamentos, escolas, seminários, faculdades, universidades etc.), modos de intervenção sobre o espaço e sobre o tempo por meio das coletividades com que se defronta, exercendo-se, sobretudo, como uma pedagogia do exemplo. A ação pedagógica missionária vem junto com os signos do martírio, da santidade, da transcendência das mais cruéis ações pautadas mesmo na violência física, mas tornada legítima tanto pelo mandato divino quanto pela postura dos missionários autoconcebida como sacrificial. ${ }^{13}$

Pode-se chamar de tradição mercantil um conjunto de saberes pouco voltado para o assenhoreamento de espaços ou populações como fins em si mesmos: trata-se aqui de produzir e controlar fluxos de interação para a troca de produtos entre povos apartados por uma radical alteridade histórico-cultural. Estão em circulação, portanto, também os conhecimentos e as formas de ação que permitem mercadejar com lucro, transpondo mundos sociais dotados de valores distintos quanto à troca, às regras de reciprocidade, ao mercado, produzindo interferências profundas na vida social dos povos vinculados por relações comerciais em contexto colonial. Algumas das operações a que os saberes mercantis procedem nesse quadro de alteridade característico das empresas coloniais são: 1) perceber a natureza e as sociedades exóticas como fornecedoras e consumidoras de bens (desde produtos até 
hábitos mentais e disposições para a ação) inexistentes em outros pontos da geografia articulada pelas redes de comércio; 2) redimensionar os significados desses bens, de modo a que possam ser objeto de consumo progressivamente mais extenso nos universos sociais em que são total ou parcialmente indisponíveis, tornando-os necessidades senão sempre intransponíveis, extremamente sedutoras e desejáveis; 3) conceber e regular relações que permitam obter, transportar, circular em amplos circuitos e vender de maneira extensiva esses novos produtos nas órbitas de mercados percebidas como privilegiadas para eles.

O estoque de saberes/fazeres para o funcionamento de sistemas escravistas talvez seja o melhor conhecido no tocante ao império português e ao Brasil. Todavia, a perspectiva de abordar uma dimensão do escravismo como uma tradição de conhecimento para gestão colonial pode ajudar a suscitar outras questões. Cabe indagar de que modo se construíram, comunicaram e reproduziram os conhecimentos necessários a: 1) reduzir e transportar cativos transformando-os em escravos, desenraizando-os culturalmente e inserindo-os parcialmente em outro meio cultural (em especial quanto aos modos de trabalho) mantendo a hierarquização e a desigualdade; 2) imobilizar e controlar, fazer produzir e reproduzir-se, docilizar e cooptar, reprimir e dividir contingentes populacionais estrangeiros, transformados em um tipo de mão de obra em aparência destituído de outro valor que não o de seu uso como força de trabalho. De que modo surgem, são elaborados e transmitidos os conhecimentos para a administração de plantéis de escravos? Qual é sua genealogia, desde a escravidão no mundo antigo até os alvores do mundo dos descobrimentos? Apoiam-se em textos e um saber codificado ou se transmitem também e, sobretudo, no plano da oralidade? Como são transformados e em que idiomas de comunicação são veiculados e retidos? Quais os seus especialistas e os públicos a que se destinam?

O âmbito próprio da tradição escravista não deve ser confundido com o da tradição sertanista, que se remete à exploração dos espaços e aos momentos iniciais da conquista de povos pela empresa colonizadora, embora comporte o apresamento de cativos para o trabalho. Tampouco é o mesmo da tradição mercantil, em que é a mercadoria escravo - e não seu trabalho e a riqueza que pode produzir que está em jogo. Muito menos o estatuto de populações escravizadas - não só as de origem nativa ao espaço da colônia, mas também e, sobretudo, as para ele transplantadas - é matéria de indagação similar à da tradição missionária, que supõe a liberdade potencial ou futura dos gentios, e espaços como as missões e os aldeamentos. O espaço próprio à geração e operação dos saberes que se pode agregar como uma tradição escravista é o das unidades domésticas. Suas formas de exercício de poder são coextensivas à gestão de grandes parentelas e de suas clientelas associadas. Uma tradição escravista é configurada por saberes para a gestão cotidiana de unidades produtivas de base familiar, por padrões de interação que se 
desenvolvem em espaços domésticos (como em propriedades rurais), ou a partir deles (como em situações de escravidão urbana), padrões estes que permitem a perpetuação dessas unidades. Nessa escala, os poderes de Estado - e os processos de sua formação - mostram-se indissociáveis das relações familiares e pessoais que em tal âmbito são essencialmente, mas não só, relações de poder, uma variedade de ação sobre ações, das quais a violência física é um limite emblemático e sua caução última: trata-se aqui de extrair o máximo de valor por meio da compulsão extraeconômica ao trabalho.

\section{A Tradição Atualizada: os técnicos em indigenismo da Funai}

Uso hipoteticamente a ideia de tradições de conhecimento para gestão colonial da desigualdade para ressaltar como diferentes correntes de tradições culturais se cruzam, ainda na atualidade, na formação e no exercício profissional de uma categoria administrativa de agentes coloniais do Estado brasileiro. Refiro-me àqueles que, até momentos recentes, ocuparam a posição de únicos especialistas em índios: os técnicos em indigenismo, concebidos para a função de chefes de posto, mas que também atuariam em muitos outros âmbitos na fundação. ${ }^{14}$

O técnico em indigenismo da Funai é, assim, um cargo dentro da hierarquia burocrática. Foi o suporte sobre o qual se generalizou a noção de indigenista como aquele que trabalha em defesa das sociedades indígenas, e é possível ampliar seu uso para os funcionários do aparelho como um todo, estejam eles hoje dentro ou fora da Funai. ${ }^{15}$ São aqueles indivíduos assim (auto)designados, que passaram por certos ritos de treinamento (como, por exemplo, os cursos de indigenismo); que integraram, ou integram, certas redes sociais; que comungaram de certos pressupostos ideológicos em seu trabalho com as sociedades indígenas, qualquer que tenha sido ou seja sua formação acadêmica.

A preocupação em treinar pessoal para o trabalho direto com as sociedades indígenas, notadamente o da função de chefe de posto indígena, não é nova. Ela já estava implícita na década de 1940 na proposta de criação de um instituto indigenista brasileiro. Na década de 1950, esse treinamento apareceu como um dos principais objetivos da criação de um curso de especialização na disciplina, desenvolvido no Museu do Índio, voltado para capacitação de pessoal em antropologia, com o duplo propósito de produzir pesquisas em etnologia e difundir um padrão de inspiração científica para o trabalho de proteção das populações indígenas. Organizado por Darcy Ribeiro, o curso teve a participação de diversos professores conferencistas de outras instituições de pesquisa e ensino, dentre elas o Museu Nacional, por meio da presença do professor Luiz de Castro Faria (Souza Lima, 2002; Freire, 2005). 
Contudo, foi com a criação da Funai e com o surgimento oficial de um cargo de técnico em indigenismo que se faria sentir a necessidade ainda mais aguda de treinar pessoal para o exercício de uma série de funções. As discussões iniciais de criação da Funai, quando por breve tempo um conselho deliberativo propôs-se a pensar um novo modelo de ação do Estado ante as sociedades indígenas, retomaram essa questão. O primeiro curso de treinamento de técnicos em indigenismo, proposto em 1969 e realizado em 1970 - a ele seguiram-se outros oito cursos, o último em 1985 -, sairia já no período da ditadura militar e desenvolvimentista, em que o imperativo era a expansão para a Região Amazônica (Davis, 1978). Seu propósito inicial era não apenas treinar novos funcionários, mas também qualificar os quadros de ação direta já existentes, muitos deles sem o ensino médio completo, exigência que se deveria cumprir para ascender ao cargo de técnico em indigenismo. Esses indivíduos eram recrutados localmente, remanescentes da administração do SPI, que exerciam de direito funções inferiores, mas eram de fato chefes de posto indígena. Era preciso dar-lhes os diplomas necessários à ascensão profissional de modo a conferir à Funai um corpo funcional qualificado. Essa mescla entre concursados e antigos funcionários continuou a existir durante algum tempo nos cursos, gerando dissonâncias óbvias.

Os conteúdos dos cursos também eram expressivos do período da ditadura militar no país. De início, marcado o destino desenvolvimentista e expansionista do aparelho, os cursos voltavam-se para o ensino das técnicas agrícolas que deveriam ser repassadas aos índios, de noções de "desenvolvimento comunitário, primeiros socorros, sobrevivência na selva, operação de rádio e das rotinas burocráticoadministrativas da Funai". Pouco a pouco, outros conhecimentos foram incorporados: noções de sociologia, de antropologia e, sobretudo, dos estudos etnológicos, além de noções e técnicas de investigação em linguística. Para alguns dos participantes, tudo isso era novidade, para outros era inócuo: mesmo dentre os concursados e novos pretendentes a cargos, havia níveis diferentes de informação quanto aos problemas indígenas, experiências de vida muito distintas. É bom lembrar que o segundo grau (o ensino médio) era o único pré-requisito aos candidatos ao concurso público para essa carreira de Estado e que o ensino médio no Brasil não incluía, naquela época, sociologia, e não inclui, até hoje, antropologia. Apesar das leis hoje vigentes, os conteúdos sobre a presença indígena nos estudos de história e de geografia no ensino médio e no superior eram e continuam sendo superficiais e simplificadores.

Os cursos contavam também com duas outras formas de transmissão de conhecimentos: 1) palestras de indigenistas experientes, isto é, funcionários da Funai (alguns pertencentes aos quadros do extinto SPI) com longo tempo de permanência entre populações indígenas, alguns com a marca da experiência nos processos de atração e pacificação de grupos arredios ou hostis - muitos deles ocupantes do cargo de sertanista, também existente no plano de cargos e salários da Funai; 2) um estágio 
de campo, após a parte teórica do curso, isto é, em termos ideais, o pretendente ao cargo deveria se deslocar para um posto indígena da Funai no qual trabalharia sob a supervisão de um chefe de posto experiente, devendo, ao final, produzir um relatório.

Essas duas dimensões dos cursos merecem atenção. As palestras e o estágio criavam um espaço de transmissão de conhecimentos, em estado prático e assistemático que deveria permitir aos neófitos se identificarem com o que viriam a fazer, terem acesso a uma tradição de conhecimentos, portanto conviverem com diferentes imagens do trabalho indigenista. No estágio de campo, eram obrigados a escrever sobre suas experiências de trabalho. A escrita fez parte das rotinas dos chefes de postos, antes que diversos fatores justificassem o uso da oralidade como registro preferencial, dentre eles o progressivo desmantelamento da estrutura administrativa da Funai, a inexistência de recursos destinados aos projetos de desenvolvimento comunitário (ou mesmo ao trabalho assistencial mais elementar), além da falta de outros suportes, como equipe de trabalho, uma área administrativa-meio que contribuísse criativamente para a atividade-fim etc. Na verdade, os relatórios serviam também a uma função até hoje não cumprida pela estrutura organizacional da Funai: a de recolher e sistematizar informações para a administração central sobre o que se passava nas áreas indígenas.

Está aí um formato de administração pouco centralizada, em que o jogo de negociação que a mantém em funcionamento constrói regiões de influência que não coincidem com as circunscrições administrativas, permitindo-se uma máxima dispersão da malha governamental muitas vezes assente em alianças duvidosas e alicerçada em redes de clientelismo em diversas escalas. Mais do que em qualquer outro lugar, o já mencionado caráter ambíguo da tutela encontra aí um lugar privilegiado.

Os relatórios elaborados sobre os estágios nem sempre apresentaram as experiências como positivas. Lendo o material ou interrogando a memória dos que passaram pelos cursos, tem-se a impressão de que o estágio propiciava a gênese de uma crítica comum à fundação feita por todos os entrevistados e, consequentemente, de uma das bases de sua solidariedade interna como corpo profissional e administradores. Segundo esses técnicos, alguns se reportando inclusive ao momento de seus estágios, o funcionário quando em área indígena contava consigo próprio e com a boa relação que pudesse estabelecer entre a coletividade indígena com que iria habitar, com segmentos da população regional, com outros funcionários estatais, com missionários etc., sendo jogado à sua sorte pela estrutura administrativa-meio e tendo que, muitas vezes, aprender, de saída, a lutar contra segmentos da própria Funai.

O curso de 1985 apresentou um diferencial se comparado aos anteriores: surgiu no momento em que os funcionários que haviam sido expurgados do aparelho ao longo dos tempos mais duros do regime ditatorial voltavam à Funai, e tinha 
uma intenção declarada de mudança. Pretendia formar indivíduos críticos da ação do Estado, que rompessem com alguns vícios consagrados na prática do trabalho indigenista, em diálogo com experiências produzidas por antropólogos, missionários e outros indigenistas da Funai que desenvolveram práticas alheias às do controle tutelar mais estrito (ou simplesmente alheias a procedimentos corruptos e corruptores). Pensava-se a tarefa indigenista menos como de mediação e mais como de assessoramento e parceria com as sociedades indígenas. Assim, esperava-se vivificar a prática e dar um passo na reformulação da máquina administrativa da Funai desde dentro.

Uma vez tendo completado o curso, o técnico em indigenismo era deslocado para uma área indígena, onde tinha que desenvolver algum trabalho como lhe fosse possível. Muitas vezes, o que pôde fazer foi performatizar no nível local a existência de uma autoridade federal, um elo isolado de uma cadeia mais figurada que real, capaz de se articular e transmitir informações para fora da área em busca de auxílio, encenando um poderio que jamais existiu ou existiria, operando a mágica do Estado - que como toda mágica guarda em si as condições de sua eficácia. No limite, e na medida em que não existiam recursos disponíveis para atividades de interesse de e para os povos indígenas, o que muitas vezes acontecia era que o indigenista ficava em estado de perplexidade solitária, sem diálogos, sem troca de conhecimentos com outros técnicos da própria Funai e, às vezes (quando não os via como potenciais inimigos e rivais), com eventuais antropólogos ou missionários, ou com os índios.

Se a Funai não apresentava recursos regulares e não cobrava planejamentos a eles correspondentes, tampouco era possível ter propostas de intervenção claras - o que se agravaria pelas próprias regras de execução orçamentária da União, que atuavam (e atuam) mais obstaculizando que controlando os gastos públicos nos rincões longínquos - nos sertões, para usarmos um termo anacrônico. Obrigados a inventar soluções, os executores diretos das políticas de Estado para índios viam-se à mercê de outros funcionários ligados às atividades-meio (a "área administrativa" sempre mencionada como odiosa) e não às atividades-fim da fundação. Em alguns casos, as soluções possíveis para obtenção de recursos para operação em escala local foi empregar os próprios indígenas como funcionários da fundação, inserindo-os como parte da malha estatal, uma das formas para crescimento da rede de clientelas entre índios e administradores que suporta sua existência nacional. Em outros momentos, a estratégia foi conseguir aposentadorias pelo Fundo de Assistência ao Trabalhador Rural (Funrural), órgão de assistência aos trabalhadores rurais, como forma de fazer chegar recursos que mitigassem a fome e a doença entre as sociedades indígenas. Em todos esses casos, com um investimento financeiro mínimo na ação direta, assegurou-se uma crescente integração entre coletividades indígenas e malha administrativa estatal. Desde a administração de Márcio Santilli 
na presidência da Funai, de setembro de 1995 a março de 1996, foi possível saber o quanto o número de funcionários indígenas era na época expressivo e o quanto os seus salários pesavam na economia de certas aldeias.

Sem sistema de qualificação ou ascensão por mérito numa carreira, um técnico em indigenismo, quando começava a compreender e estabelecer as relações necessárias a atuar em uma sociedade indígena, poderia ser transferido para outra circunscrição administrativa e ter que recomeçar aparentemente do nada em outra região do país. Outro destino possível na trajetória desses especialistas foi passar para instâncias não locais da estrutura burocrática da Funai. Entretanto, em algumas situações, houve quem se envolvesse em práticas corruptas: muitas vezes, cioso de seu micropoder, orgulhoso da tutela, o técnico em indigenismo, ou mais frequentemente o que exercia a função de chefe de posto, transformou-se num régulo local, como há muitos na administração pública brasileira, gerindo clientelas, engajando-se em todo tipo de exploração do trabalho e dos recursos naturais de uma coletividade indígena, que adquiriu assim seu elo próprio de acesso a múltiplas redes estatizadas ou não e seus recursos. Ou, então, o heroísmo sacerdotal, presente em muitas vocações e intenções de trabalho com as sociedades indígenas, levou com facilidade à arrogância, ao fechamento sectário e corporativo, ao antagonismo contra todas as formas de aliança com atores de fora da agência, contra todas as formas de registro e reflexão sobre um trabalho tão delicado quanto todo aquele que envolve as vidas de sociedades humanas em contato.

De qualquer forma, o período dos fins dos anos 1980 até o presente viu a aparente derrocada da ação tutelar, já divisada nos materiais que mostram a precariedade com que os agentes do exercício tutelar operavam, e como, alicerçados em múltiplos conhecimentos, eles por tanto tempo figuraram uma ação de Estado para os povos indígenas, sempre insuficiente ou diferencialmente distribuída, e sempre (e ainda hoje) demandada. Sem sombra de dúvida, as condições de exercício da ação de governo sobre as coletividades indígenas, agora expurgada do termo tutela, após tantas alterações regimentais e diante de tantos outros cortes de funções e de orçamento, indiscutivelmente mudaram. Em investimentos futuros, teríamos de nos perguntar em que medida tais alterações repercutiram nos saberes/fazeres, nos repertórios e nas práticas que fizeram de uns tutores e de outros tutelados. 


\section{Os Mortos Capturam os Vivos? Algumas observações finais ${ }^{16}$}

No campo da saúde pública, a epidemiologia, como saber aplicado pelos profissionais de saúde, englobaria as práticas de higiene como se esta fosse uma dimensão onde apenas reinassem as bactérias, micróbios e vírus, quando em verdade estamos no domínio da distinção social, e mais propriamente de um tipo de distinção na qual os povos indígenas tendem a serem vistos e enquadrados, de maneira ainda mais incisiva pela população local, como pessoas que possuem um estatuto "privilegiado" em relação ao poder federal e às autoridades públicas. Esse tipo de deslocamento interpretativo dado à diferença cultural é como uma releitura da tutela, no sentido de que constrói uma relação a partir da afirmação de relativa incapacidade do outro, ainda que juridicamente a tutela já não exista mais. De fato, encontrei profissionais de saúde - entre agentes de endemias da Funasa e auxiliares de enfermagem - atuando diariamente nas aldeias, que não tinham conhecimento dessa legislação e acreditavam ser a tutela a nível jurídico a única explicação pela qual os povos indígenas teriam direito a um subsistema de saúde e a uma logística distrital. (Dias da Silva, 2010: 261)

Parti da indagação sobre como se aprende a exercer funções na administração pública sem que se tenha recebido treinamento formal para tanto. Tal pergunta tem uma funcionalidade: uma das queixas mais persistentes dos agentes da saúde indígena é a falta de capacitação, melhor dizendo, a ausência de uma formação que os tivesse preparado para trabalhar com coletividades indígenas. Então como o fazem? E como o fazem de modo tão próximo ao dos chamados técnicos em indigenismo da Funai? Fiz essas perguntas no início deste capítulo e procurei responder a elas trilhando a trajetória da formação de técnicos em indigenismo com a hipótese de que à sua formação, pautada largamente na prática, afluem correntes de tradições de conhecimento para a gestão colonial da desigualdade, para tanto seguindo o que chamei de poder tutelar como desdobramento da empresa colonizadora pautada na guerra de conquista.

O indigenista, como figura-tipo da administração tutelar, atua como um especialista na gestão de situações de pluralidade cultural internas ao Brasil, as quais muitas vezes ele administra imaginando-as como de conflito aberto, como uma guerra, o que não quer dizer que em certos casos elas não existam de fato. Contudo, em muitas outras situações tal figuração atende a lugares comuns que conformam a interação pluriétnica como uma emergência em que vidas humanas, pensadas do ponto de vista de um individualismo biologizante, estão em jogo. O forte apelo moral implícito na atenção biomédica à saúde apoia-se numa dada concepção (biopolítica) da vida como objeto de governo (Foucault, 2004) do mais alto valor. A preservação e a segurança da vida podem mesmo justificar o uso da violência 
física sobre os corpos. A persistência das coletividades como tais não necessariamente é considerada. Vemos aí se reinstaurar o que George Balandier (1951) chamou de situação colonial.

O técnico em indigenismo, como agente de uma administração colonial, formou seu modus operandi no singular entrecruzamento de tradições de conhecimento explicitamente invocado pelos engenheiros militares filiados ao positivismo ortodoxo brasileiro quando da implantação do SPI em 1910: mistura de missionarismo e martírio, de sertanismo heroico, desbravador e nacionalizante, da experiência de gestão de aglomerados de trabalhadores em situação semisservil, e da ciência de evolução da humanidade - o ímpeto civilizador e expansionista estando presente em todas elas. Essas distintas tradições de que emanam diferentes saberes acabam por se reunir sob a bandeira de um Estado nacional e em agências de governo voltadas para a dimensão intraterritório brasileiro. A genealogia desse elenco de saberes está por ser adequadamente feita. Esta, sem dúvida, pode ser uma das vias de acesso não só para o melhor estudo dos processos de formação de Estado em contextos pós-coloniais, como também para a realização de uma crítica da ação política governamental contemporânea em situações concretas de intervenção quer entre os povos indígenas e outras populações tradicionais territorializadas, quer entre grandes segmentos da população brasileira (os genéricos pobres) subsumidos a lógicas de dominação similares.

Seria o caso de pensar como esse desenho amplo se atualiza hoje, o quanto mudou, o quanto permanece, o quanto se reelaborou e está presente nos repertórios para ação das políticas indigenistas de educação, saúde, meio ambiente etc. O trecho de Dias da Silva (2010) aqui mencionado evidencia essa questão. Dentre estas, a política de saúde indígena, em especial nas perspectivas de sua concepção e de sua execução cotidiana, mereceria maior atenção, e muitas pesquisas além das que estão aqui apresentadas precisam ser feitas. Como palimpsestos, as correntes de tradições culturais que se reuniram em torno do exercício tutelar e alicerçam as relações entre coletividades indígenas e populações locais e regionais ainda dão sentido a aspectos fundamentais da sua interação na vida diária. Do mesmo modo, ao se reservarem a legitimidade sobre os saberes/fazeres que preservam a vida, destituem o outro de seus conteúdos próprios, desconhecendo as tradições de conhecimentos indígenas, não importa o quanto elas tenham orientado a experiência dessas coletividades até a chegada (desbravadora, heroica, messiânica, campanhista) dos especialistas em saúde. Também estes, como os indigenistas, põem em jogo na sua lida cotidiana tecnologias tutelares de minorização (Lugones, 2013). As ações governamentais para a infância guardam sentidos similares. Todas elas imantam-se do que Adriana Vianna (2002) tão bem chamou de "opressão da bondade".

Ainda como homologia, pode-se pensar como tanto técnicos em indigenismo quanto profissionais biomédicos operando no Sistema Único de Saúde, parti- 
cularmente no Subsistema de Saúde Indígena, enfrentam uma grande precariedade quanto aos meios reais de intervenção cotidiana, sendo as epidemias as emergências que, muitas vezes, permitem que adquiram algum poderio real. Não estaria aí também um espaço importante de encenação, de figuração de uma superioridade tecnológica ilusória e de uma capacidade de proteção irreal?

Pode-se sugerir que o horizonte da guerra está presente em ambos os campos, tanto no do indigenismo, quanto no da biomedicina sanitarista, juntamente com a perspectiva imperialista de reconfiguração civilizadora em prol da vida. ${ }^{17}$

Creio que seria fácil dizer que, tanto em um como em outro, essas seriam matrizes ultrapassadas. Todavia, estarão, de fato, ausentes das práticas, dos saberes/ fazeres e disposições que orientam as ações indigenistas? Há muito a ser pesquisado e cruzado nessa interface ainda de modo a que nos libertemos do trabalho morto simbólico que, como os mortos, no dito positivista ortodoxo comtiano ("a humanidade compõe-se mais de mortos que de vivos"), ocupa mais espaço do que o esforço do (re)pensar. Este capítulo pretendeu apenas instigar um debate que urge ser feito.

\section{Notas}

1 Este texto foi apresentado como comunicação oral em mesa-redonda organizada pelas organizadoras deste livro na Reunião Brasileira de Antropologia de 2008. Resulta de uma pesquisa ampla sobre o que chamo aqui de poder tutelar mediante uma análise de antropologia histórica do Serviço de Proteção ao Índio (SPI), cujos produtos principais podem ser vistos em Souza Lima (1995, 2002, 2009). Apoia-se, ainda, no estudo da formação de técnicos em indigenismo da Fundação Nacional do Índio, parcialmente apresentada em Souza Lima (2007) e Saldanha (1996). Agradeço a Carla Teixeira e Luiza Garnelo pelo estímulo e paciência como coordenadoras com meu ritmo na preparação deste texto e especialmente a Laura Belen Navallo Coimbra pela leitura atenta, pelas sinalizações detalhadas e pela incomensurável ajuda no trabalho de carpintaria final deste capítulo.

2 Para mais trabalhos dedicados a pensar outros aspectos do exercício do poder tutelar, ver Barroso-Hoffmann (2009), Chuva (2009), Corrêa (2000, 2003, 2008), Costa (2008), Lugones (2013), Ramos (2006), Vianna (1999, 2002, 2003), Souza Lima (2014).

3 Sobre esse assunto, que é de grande significação, Cristina Dias da Silva (2010) apresenta informações inestimáveis (ver também capítulo 6 deste volume).

4 "a guerra é condição característica, e a força armada do instrumento característico, do sistema de Estado" (tradução minha).

5 Veja-se Ribeiro (1962), replicado em Ribeiro (1977), para uma visão muito disseminada que procura pôr na balança erros e acertos do SPI de modo a defender sua permanência dentre as agências de Estado e propor sua reformulação. Em Pacheco de Oliveira e Almeida (1998), encontra-se uma crítica radical da ação cotidiana da Funai, em especial no tocante à criação 
administrativa de terras indígenas. Os autores chamaram de emergencialismo o traço pelo qual a retórica institucional apresentava certos momentos e circunstâncias na ação da agência junto aos indígenas como situações de vida ou morte para que efetivamente certos processos deslanchassem.

6 Sobre as críticas à noção de cultura em antropologia a que estou me referindo, ver Frederik Barth (1995).

7 Para a ideia de cadeias de autoridades, ver Ramos (2006). Para um estudo exemplar na direção da percepção indígena com base em sua cosmologia da ação tutelar e sua relação e disjunção com a forma como esta é concebida pelos agentes tutelares, ver Pacheco de Oliveira (1988).

8 Ver, para uma perspectiva antropológica de análise de políticas públicas, Souza Lima e Castro (2008), Teixeira e Souza Lima (2010), dentre muitos outros trabalhos.

9 "Ao analisar o pluralismo cultural em algumas áreas do Oriente Médio, considerei esclarecedor pensar em termos de correntes (streams) de tradições culturais (...), cada uma delas exibindo uma agregação empírica de certos elementos e formando conjuntos de características coexistentes que tendem a persistir ao longo do tempo, ainda que na vida das populações locais e regionais várias dessas correntes possam misturar-se. Tal modelo envolvendo diferentes correntes de tradições culturais não implica nenhuma suposição predefinida sobre o que exatamente mantém juntos os elementos de cada tradição coexistente - afinal é exatamente isso que estamos tentando descobrir - nem expectativa alguma de que todas elas tenham características homólogas e dinâmicas básicas semelhantes. Elas podem ser constituídas e se reproduzir de diferentes maneiras. O principal critério é que cada tradição mostre um certo grau de coerência ao longo do tempo, e possa ser reconhecida nos vários contextos em que coexiste com outras em diferentes comunidades e regiões" (Barth, 2000: 123-124, grifos do original). Ver também Barth (1975, 1982, 1993, 1995).

10 Uma extensa literatura teorizando a colonização, descrevendo a geografia e a natureza dos espaços colonizados, discutindo a natureza e os direitos dos povos conquistados e propondo métodos de intervenção desdobra-se desde a Antiguidade (mediterrânea) europeia e ganha especial alento a partir das invasões das Américas. É sempre interessante lembrar que, discutindo a gênese do capitalismo em O Capital, Karl Marx (1978) dedica o último capítulo do tomo I, logo após o capítulo sobre a acumulação originária do capital, à moderna teoria da colonização, quando analisa cuidadosamente a literatura colonialista da época.

11 Em Monteiro (1999), há uma interessante análise de documentos que nos reportam aos tempos por excelência de constituição do sertanismo.

12 Para a ideia de poder pastoral (ou pastorado cristão), ver Foucault $(1990,2004)$. Na verdade, um estudo que cruzasse as técnicas do que Foucault chama de governo - tomando tal forma de poder como voltada para o controle da vida - com destaque para o lugar do pastorado nelas, trabalhando sobre uma comparação sistemática entre o sanitarismo, em sua vertente mais imperial e militarizada, e o sertanismo que alicerça um indigenismo brasileiro traria um avanço ponderável - inclusive para se pensar a muito relativa eficácia do Sistema Único de Saúde no cotidiano de regiões longínquas do território nacional.

13 Em Castelnau-L'Estoile (2000) encontramos uma análise particularmente estimulante da empresa jesuítica de conversão dos gentios no Brasil. Vejam-se também, em Pacheco de 
Oliveira (2011), estudos sobre a ação missionária no Nordeste brasileiro, demonstrando alguns dos seus aspectos mais violentos.

14 Como mencionado no início, faço as interpretações seguintes com base em minha própria pesquisa sobre o SPI e, mais recentemente, sobre a Funai e à luz da monografia de conclusão de graduação de Luiza Saldanha (1996). A muitíssimo parcial reestruturação da Funai de 2010 e os concursos para novos quadros na gestão de Marcio Meira introduziram novos elementos no cenário. Ver Souza Lima (2011).

15 Sobre a diferença do que se entende por indigenismo no seu contexto de origem, o México, sobretudo, e o Brasil e também sobre a migração dessa categoria, ver Souza Lima (2002).

16 Ver Bourdieu (1989) para a expressão "os mortos capturam os vivos".

17 Ver Arnold (1988) e Bastos (1998, 2004, 2007) para algumas análises nessa direção.

\section{Referências}

ANDERSON, B. Imagined Communities. London, New York: Verso, 1991.

ARNOLD, D. (Ed.). Imperial Medicine and Indigenous Societies. Manchester, New York: Manchester University Press, 1988.

BALANDIER, G. La situation coloniale. Cahiers Internationaux de Sociologie, 11: 44-79, 1951.

BARROSO-HOFFMAN, M. Fronteiras Étnicas, Fronteiras de Estado e Imaginação da Nação: um estudo sobre a cooperação internacional norueguesa junto aos povos indígenas. Rio de Janeiro: E-papers, 2009.

BARTH, F. Ritual and Knowledge Among the Baktaman of New Guinea. Oslo, New Haven: Universitetsforlaget, Yale University Press, 1975.

BARTH, F. Problems in conceptualizing cultural pluralism, with illustrations from Sohar, Oman. In: MAYBURY-LEWIS, D. G PLATTNER, S. (Eds.). Prospects for Plural Societies. Washington, D.C.: American Ethnological Society, 1982.

BARTH, F. Balinese Worlds. Chicago: Chicago University Press, 1993.

BARTH, F. Other knowledge and other ways of knowing. Journal of Anthropological Research, 51(1): 65-68, 1995.

BARTH, F. O Guru e o Iniciador e Outras Variações Antropológicas. Rio de Janeiro: Contra Capa, 2000.

BASTOS, C. Germ theories in a colonial setting: medical theories and military practices in late nineteenth century Goa, India. EASST Review, 17(4): 9-12, 1998.

BASTOS, C. O ensino da medicina na Índia colonial portuguesa: fundação e primeiras décadas da Escola Médico-Cirúrgica de Nova Goa. História, Ciências, Saúde-Manguinhos, 11(1): 11-39, 2004. 
BASTOS, C. Medicina, império e processos locais em Goa, século XIX. Análise Social, 182: 99-122, 2007.

BOURDIEU, P. Le mort saisit le vif: as relações entre a história reificada e a história incorporada. In: BOURDIEU, P. O Poder Simbólico. Lisboa, Rio de Janeiro: Difel, Bertrand Brasil, 1989.

CASTELNAU-L'ESTOILE, C. Les Ouvriers d'une Vigne Sterile: les jésuites et la conversion des indiens au Brésil, 1580-1620. Lisboa, Paris: Centre Culturel Calouste Gulbenkian, Commission Nationale pour les Commémorations des Découvertes Portugaises, 2000.

CHUVA, M. R. R. Os Arquitetos da Memória: sociogênese das práticas de preservação do patrimônio cultural no Brasil (anos 1930-1940). Rio de Janeiro: Editora da UFRJ, 2009.

CORRÊA, J. G. S. A Ordem a se Preservar: a gestão dos índios no Reformatório Agrícola Indígena Krenak, 2000. Dissertação de Mestrado, Rio de Janeiro: Museu Nacional, Universidade Federal do Rio de Janeiro.

CORRÊA, J. G. S. A administração dos índios: as diretrizes para funcionamento dos povos indígenas. In: SOUZA LIMA, A. C. (Org.). Gestar e Gerir: estudos para uma antropologia da administração pública. Rio de Janeiro: Nuap, Relume-Dumará, 2003.

CORRÊA, J. G. S. Tutela G Desenvolvimento/Tutelando o Desenvolvimento: questões quanto à administração do trabalho indígena pela Fundação Nacional do Índio, 2008. Tese de Doutorado, Rio de Janeiro: Museu Nacional, Universidade Federal do Rio de Janeiro.

COSTA, G. V. L. O Aventureiro, Ilha Grande-RJ: uma análise de mudança social, 2008. Tese de Doutorado, Rio de Janeiro: Museu Nacional, Universidade Federal do Rio de Janeiro.

DAVIS, S. H. Vítimas do Milagre. Rio de Janeiro: Zahar, 1978.

DIAS DA SILVA, C. Cotidiano, saúde e política: uma etnografia dos profissionais da saúde indígena, 2010. Tese de Doutorado, Brasília: DAN, Universidade de Brasília.

FOUCAULT, M. Vigiar e Punir. Petrópolis: Vozes, 1977.

FOUCAULT, M. The subject and power. In: RABINOW, P. G DREYFUSS, H. (Eds.). Michel Foucault: beyond structuralism and hermeneutics. Chicago: The University of Chicago Press, 1983

FOUCAULT, M. Omnes et singulatim: por uma crítica da razão política. Novos Estudos Cebrap, 26: 77-99, 1990.

FOUCAULT, M. Il Faut Défendre la Société: cours au Collège de France. Paris: Seuil, Gallimard, 1997.

FOUCAULT, M. Sécurité, Territoire, Population: cours au Collège de France, 1977-1978. Paris: Seuil, Gallimard, 2004.

FREIRE, C. A. R. Sagas Sertanistas: práticas e representações do campo indigenista no século $X X, 2005$. Tese de Doutorado, Rio de Janeiro: Museu Nacional, Universidade Federal do Rio de Janeiro. 
GEERTZ, C. Negara: o Estado teatro no século XIX. Lisboa, Rio de Janeiro: Difel, Bertrand, 1991.

LUGONES, M. G. Obrando en Autos, Obrando en Vidas: formas y fórmulas de protección judicial en los tribunales prevencionales de menores de Córdoba, Argentina, a comienzos del siglo XXI. Rio de Janeiro: E-papers, 2013.

MARX, K. La moderna teoría de la colonización. In: MARX, K. El Capital. México, DF: Fondo de Cultura Económica, 1978. t. I.

MONTEIRO, J. M. Os caminhos da memória: paulistas no Códice Costa Matoso. Varia História, 21: 86-99, 1999.

PACHECO DE OLIVEIRA, J. O Nosso Governo: os Ticuna e o regime tutelar. São Paulo, Brasília: Marco Zero, CNPq, 1988.

PACHECO DE OLIVEIRA, J. (Org). A Presença Indígena no Nordeste: processos de territorialização, modos de reconhecimento e regimes de memória. Rio de Janeiro: Contra Capa, 2011.

PACHECO DE OLIVEIRA, J. G ALMEIDA, A. W. B. Demarcação e reafirmação étnica: um ensaio sobre a Funai. In: OLIVEIRA FILHO, J. P. (Org.). Indigenismo e Territorização: poderes, rotinas e saberes coloniais no Brasil contemporâneo. Rio de Janeiro: Contra Capa, 1998.

PACHECO DE OLIVEIRA, J. G FREIRE, C. A. R. A Presença Indígena na Formação do Brasil. Brasília, Rio de Janeiro: MEC/Secad, Laced/Museu Nacional, 2006. Disponível em: < www. trilhasdeconhecimentos.etc.br/livros/arquivos/ColET13_Vias02WEB.pdf $>$. Acesso em: 19 ago. 2014.

RAMOS, J. S. O Poder de Domar do Fraco: formação de autoridade e poder tutelar na política de povoamento do solo nacional. Niterói: EdUFF, 2006.

RIBEIRO, D. A Política Indigenista Brasileira. Rio de Janeiro: Ministério da Agricultura, 1962.

RIBEIRO, D. Os Índios e a Civilização. Petrópolis: Vozes, 1977.

SALDANHA, L. Escola de Heróis: os cursos de formação de técnicos em indigenismo da Funai, de 1974 a 1985, 1996. Monografia, Rio de Janeiro: Instituto de Filosofia e Ciências Sociais, Universidade Federal do Rio de Janeiro.

SILVA, C. D. Cotidiano, Saúde e Política: uma etnografia dos profissionais da saúde indígena, 2010. Tese de Doutorado, Brasília: Departamento de Antropologia, Universidade de Brasília.

SIMMEL, G. The Sociology of Georg Simmel. New York: The Free Press, 1964.

SOUZA LIMA, A. C. Um Grande Cerco de Paz: poder tutelar, indianidade e formação de Estado no Brasil. Petrópolis: Vozes, 1995.

SOUZA LIMA, A. C. Indigenismo no Brasil: migração e reapropriações de um saber administrativo. In: L'ÉSTOILE, B.; NEIBURG, F. G SIGAUD, L. (Orgs.). Antropologia, Impérios e Estados Nacionais. Rio de Janeiro: Relume-Dumará, Faperj, 2002. 
SOUZA LIMA, A. C. Tradições de conhecimentos na gestão colonial da desigualdade: reflexões a partir da administração indigenista no Brasil. In: BASTOS, C.; ALMEIDA, M. V. G FELDMAN-BIANCO, B. (Orgs.). Trânsitos Coloniais: diálogos críticos luso-brasileiros. Campinas: Editora da Unicamp, 2007.

SOUZA LIMA, A. C. As Órbitas do Sítio: subsídios para o estudo da política indigenista no Brasil, 1910-1967. Rio de Janeiro: Contra Capa, Laced/Museu Nacional/UFRJ, 2009.

SOUZA LIMA, A. C. A participação indígena no contexto dos governos Lula. In: RICARDO, B. G RICARDO, F. (Orgs.). Povos Indígenas no Brasil: 2006-2010. São Paulo: Instituto Socioambiental, 2011.

SOUZA LIMA, A. C. (Org). Tutela: formação de Estado e tradições de gestão no Brasil. Rio de Janeiro: E-papers, 2014.

SOUZA LIMA, A. C. S. G CASTRO, J. P. M. Política(s) pública(s). In: PINHO, O. G SANSONE, L. (Orgs.). Raça: perspectivas antropológicas. Salvador: ABA, Edufba, 2008.

TEIXEIRA, C. C. G SOUZA LIMA, A. C. A antropologia da administração e da governança no Brasil: área temática ou ponto de dispersão? In: DUARTE, L. F. D. G MARTINS, C. B. (Coords.). Horizontes das Ciências Sociais no Brasil: antropologia. São Paulo: Anpocs, 2010.

TILLY, C. Reflections on the history of european state-making. In: TILLY, C. (Ed.). The Formation of National States in Western Europe. Princeton: Princeton University Press, 1975.

TILLY, C. How do relations store history? Annual Review of Sociology, 26: 721-723, 2000.

TODOROV, T. A Conquista da América: a questão do outro. 2. ed. São Paulo: Martins Fontes, 1988.

TURNER, V. Pilgrimages as social processes. In: TURNER, V. Dramas, Fields and Metaphors. Ithaca, London: Cornell University Press, 1974.

VIANNA, A. R. B. O Mal que se Adivinha: polícia e menoridade no Rio de Janeiro, 19101920. Rio de Janeiro: Arquivo Nacional, 1999.

VIANNA, A. R. B. Limites da Menoridade: tutela, família e autoridade em julgamento, 2002. Tese de Doutorado, Rio de Janeiro: Museu Nacional, Universidade Federal do Rio de Janeiro.

VIANNA, A. R. B. Quem deve guardar as crianças? Dimensões tutelares da gestão contemporânea da infância. In: SOUZA LIMA, A. C. (Org.). Gestar e Gerir: estudos para uma antropologia da administração pública. Rio de Janeiro: Nuap, Relume-Dumará, 2003. 


\section{Antropologia e Medicina: \\ a saúde no Serviço de Proteção aos Índios (1942-1956)}

Carolina Arouca

Nísia Trindade Lima

Ausência, inoperância e ineficiência são termos muito utilizados tanto em textos de época quanto em análises contemporâneas sobre o Serviço de Proteção aos Índios (SPI). Aplicáveis a problemas como acesso à terra e proteção ante interesses contrários às populações indígenas, parecem encontrar ainda maior expressão no que concerne às suas condições de saúde. De fato, esse tema era praticamente invisível no âmbito da Política Nacional de Saúde e tratado de forma incipiente no SPI de 1910 a 1967, ou seja, ao longo de seus 57 anos de atuação. De acordo com autores que ao SPI se dedicaram, sua maior visibilidade viria a ocorrer na década de 1950, sobretudo a partir da atuação do médico Noel Nutels e da criação do Serviço de Unidades Sanitárias Aéreas (Susa), vinculado ao Serviço Nacional de Tuberculose do Ministério da Saúde (Santos et al., 2009; Paz, 1994; Costa, 1987).

A ênfase na ineficiência das ações e na avaliação das políticas indigenistas acaba, entretanto, dificultando que se considerem outras questões relevantes, entre elas a gênese de ideias e matrizes intelectuais para a abordagem de problemas relativos à saúde indígena, assim como a reflexão mais ampla sobre as correntes de pensamento que se voltaram para as sociedades indígenas e o contato interétnico. Essa é a perspectiva adotada neste capítulo, no qual temos por objetivo analisar propostas apresentadas durante as décadas de 1940 e 1950 no SPI, considerando que elas alcançaram importantes desdobramentos nos anos que se seguiram. Um dos seus pressupostos consistia na necessidade de se criar uma especialidade - a saúde indígena - a partir de críticas às ações do Ministério da Educação e Saúde, que enfatizavam a assistência rural e a saúde das populações caboclas. Esse foi o caso do plano para a criação de um Serviço Médico-Sanitário do SPI, apresentado em dezembro de 1946 por Herbert Serpa, diretor da Seção de Estudos daquele organismo de 1944 a 1951. Consideramos que naquele momento surgiram algumas ideias sobre a especificidade que deveria orientar a saúde indígena, conformando, desse modo, uma matriz de interpretação sobre o tema, com implicações nas décadas seguintes. Com o objetivo de compreendê-la, procuramos analisar as ideias que orientaram a atuação da Seção de Estudos do SPI, em particular a discussão em 
torno do que foi então conceituado como redução demográfica indígena, problema formulado e analisado pelo antropólogo Darcy Ribeiro (Ribeiro, 1970). Com base em reflexões que vêm orientando pesquisa sobre as ciências sociais e o campo da saúde pública nas décadas de 1940 e 1950 (Maio G Lima, 2009; Lima G Maio, 2010), pretendemos contribuir para uma linha de estudos que se volta para as relações entre antropologia e saúde indígena no período em pauta.

A política indigenista e o papel do SPI têm-se constituído em objeto de importantes pesquisas, entre as quais se destaca a de Antonio Carlos de Souza Lima e sua instigante análise sobre o poder tutelar (Souza Lima, 1995). No que se refere ao papel dos antropólogos e ao objeto da antropologia no contexto da Segunda Guerra Mundial, os estudos de Mauro Almeida (2004) e Regina Érika Figueiredo (2009)1 trouxeram importantes contribuições. Entretanto, ainda não foram objeto de investigação mais aprofundada propostas apresentadas no âmbito dessa agência estatal como decorrência do encontro entre antropologia, saúde e questão indígena, e que constituem, a nosso ver, um importante capítulo da história das ciências sociais no Brasil. O estudo de tal encontro pode contribuir, em uma perspectiva histórica, para a abordagem de dilemas contemporâneos expressos tanto na produção acadêmica como na agenda de políticas públicas.

\section{Viagens Científicas e Saneamento do Brasil: prioridade às populações sertanejas ou caboclas}

A literatura que vem-se dedicando à análise da história das políticas indigenistas tem ressaltado o predomínio do discurso assimilacionista e seu prognóstico da tendência ao desaparecimento dos indígenas absorvidos pela sociedade nacional (Souza Lima, 1995; Barroso-Hoffman et al., 2004; Souza Lima G Barroso-Hoffman, 2002; Santos et al., 2009). Ainda que, com base em pressupostos teórico-metodológicos distintos, tal discurso tenha recebido críticas desde a década de 1950, no plano das políticas públicas ele só teria apresentado mudanças significativas a partir da década de 1980 com o reconhecimento, na Constituição Federal de 1988, da sociodiversidade indígena no Brasil - evidenciada pelas cerca de duas centenas de etnias encontradas no país, portadoras de diferentes línguas, cosmologias e formas de organização social e política (Santos et al., 2009; Cunha,1992). Note-se ainda que, em contraste com o prognóstico de desaparecimento, os povos indígenas se encontram atualmente em crescimento demográfico (Pagliaro, Azevedo G Santos, 2005; Santos et al., 2009). Entretanto, tal não era o cenário projetado no início do século XX.

Desde os primeiros anos de atuação do SPI, o horizonte de desaparecimento esteve presente em documentos e relatos de viagens científicas, a exemplo 
daquelas realizadas pela Comissão Construtora das Linhas Telegráficas Estratégicas de Mato Grosso ao Amazonas, a Comissão Rondon (Sá, Sá G Lima, 2008). Dos textos elaborados com base nas atividades dessa comissão, o livro Rondonia: anthropologia - ethnographia, de Edgard Roquette-Pinto (2005), pode ser tomado como exemplo bastante elucidativo. Publicado originalmente em 1917 como um relato da experiência da viagem de 1912 à Serra do Norte, onde se localizavam os povos Paresí e Nambiqwara, os últimos em fase inicial de contato com a Comissão Rondon, o livro é apresentado pelo autor como uma tentativa de "tirar um instantaneo da situação anthropologica e ethnographica, dos índios da Serra do Norte, antes que principiasse o trabalho de decomposição que nossa cultura vai nelles processando" (Roquette-Pinto, 2005: xiv).

Talvez por essa razão - a percepção do inevitável desaparecimento das sociedades Paresí e Nambiqwara - a defesa de uma etnografia sertaneja emirja como uma das principais propostas apresentadas, não obstante registros da cultura material e imaterial e das doenças identificadas pelo médico e antropólogo nessas sociedades ocuparem grande parte da obra. Nessa perspectiva, é interessante observar o lugar especial ocupado pelos Paresí na descrição das sociedades indígenas com as quais estabeleceram contato. Para Roquette-Pinto, os Paresí conformavam um exemplo de transição de "índio" para "brasileiro", processo mediado pela cultura sertaneja. Ele se referia ao processo de assimilação dos Paresí à organização social do país, entendendo que teriam deixado de ser "índios" para se transformarem em "sertanejos" (Lima, Santos G Coimbra Jr., 2005) e, valendo-se de argumento de nítida inspiração na obra clássica de Euclides da Cunha, o autor identificava nos sertanejos o cerne da nacionalidade brasileira.

O exame da trajetória do antropólogo revela que, logo após a publicação de Rondonia, ganhou relevo em suas atividades no Museu Nacional a ideia de se criar uma etnografia sertaneja com a instalação inclusive de uma sala Euclides da Cunha naquela instituição. Ocorreu também seu crescente envolvimento com as campanhas de reforma da saúde e da educação, realizadas durante as décadas de 1910, 1920 e 1930. Nelas eram mobilizadas imagens sobre a necessária redenção dos brasileiros que não estariam condenados por questões raciais e necessitariam de políticas públicas nos campos da saúde e da educação (Lima G Sá, 2008).

Como já observado em outros textos, a adesão de Roquette-Pinto ao positivismo desempenhou papel importante na obra, na qual se constata a ênfase no pertencimento de todos os povos a uma mesma humanidade, diferindo apenas quanto ao grau de civilização (Lima, Santos G Coimbra Jr., 2005). A ideia de evolução espontânea dos grupos indígenas - defendida tanto por Roquette-Pinto como por Rondon - está apoiada nessa perspectiva e se constituiu em um dos fundamentos da proposta de sua tutela pelo Estado, uma das características de longa duração da política indigenista no Brasil (Souza Lima, 1995). 
Também nos discursos de Rondon, o sertanejo, visto como cerne da nacionalidade, em perspectiva bastante semelhante à de Euclides da Cunha e RoquettePinto, era enaltecido. É o que pode ser observado na seguinte citação extraída da conferência por ele proferida durante as comemorações do segundo centenário da cidade de Cuiabá:

Mas os grandes feitos que hoje comemoramos não resultaram dessa espécie de aliança, desse concurso efetivo e necessário da capacidade coordenadora do português com a força das massas indígenas que ele submetia e dirigia. Esforços tão novos como esses que foram teatro os vastos sertões que se estendiam para além da linha de Tordesilhas exigiam, para se traduzirem em fatos, a criação de um novo tipo de homem, o mameluco, ou para melhor nos exprimirmos, exigiam o aparecimento do legítimo brasileiro - nascido da transfusão num só indivíduo das qualidades, da inteligência, de caráter e sentimento que se encontravam separadamente acentuadas, ora no europeu, ora no americano. (Rondon apud Viveiros, 1958: 468, grifo nosso)

Do mesmo modo que Roquette-Pinto expressou-se ao abordar as relações entre a Comissão Rondon e os Paresí, Rondon estabelecia contato e propunha políticas para as populações indígenas, mas identificava nos caboclos ou mamelucos, dos sertões, o arquétipo do brasileiro. Tal exaltação do sertanejo já havia encontrado espaço anteriormente na literatura romântica, mas no contexto da Primeira República ela passou a se associar a campanhas de denúncia e de mobilização da opinião pública em torno da tese da necessária integração dos sertões brasileiros, retórica fortemente associada à Comissão Rondon e aos relatórios das viagens médicas promovidas pelo Instituto Oswaldo Cruz.

No mesmo período em que era criada uma agência estatal específica para lidar com a questão indígena, sugestivamente com a denominação inicial de Serviço de Proteção aos Índios e de Localização dos Trabalhadores Nacionais, ${ }^{2}$ esboçava-se uma das características das ações de saúde pública predominantes até a década de 1980: a ênfase na saúde dos sertanejos. Assim, paralelamente à gênese do discurso assimilacionista no que se refere às sociedades indígenas, apresentou-se a proposta de recuperação das populações sertanejas, sobretudo pelo que foi posteriormente denominado movimento sanitarista da Primeira República (Santos, 1985), cujas ideias orientaram as agências voltadas para a política de saúde em nível nacional.

Ainda que fatores diferentes tenham contribuído para essa construção imaginária, consideramos que desempenharam papel de destaque as viagens científicas do início do século XX, expedições ademais que se apresentavam como missões civilizadoras da República (Lima, 1998, 1999). A partir de 1907, na mesma época em que a Comissão Rondon procurava desbravar os sertões, construir linhas telegráficas e realizar levantamento científico em extensa região do território nacional, 
intensificaram-se as viagens científicas promovidas pelo Instituto Oswaldo Cruz. As primeiras expedições destinaram-se aos trabalhos profiláticos que acompanharam ações relacionadas às atividades exportadoras, base da economia do país: construção de ferrovias, saneamento dos portos, estudos voltados para a extração da borracha na Amazônia (Lima, 1999; Thielen et al., 2002).

Foi também nesse contexto que Carlos Chagas e Belisário Penna dirigiram-se, em junho de 1907, a Lassance, no norte de Minas Gerais, por requisição da Estrada de Ferro Central do Brasil, que projetava estender a ferrovia até Belém, capital do estado do Pará. A finalidade principal era realizar a profilaxia da malária, que dizimava os trabalhadores contratados pela empresa para prolongar a linha férrea até Pirapora, no norte de Minas Gerais. Durante os trabalhos, Chagas realizou várias observações sobre um inseto hematófago, comum na região, popularmente conhecido como barbeiro. Verificou que o inseto era o vetor de uma doença até então desconhecida, que associou a uma série de manifestações mórbidas. Causada por um protozoário denominado por Carlos Chagas de Trypanosoma cruzi, a doença recebeu inicialmente o nome científico de tripanossomíase americana, e posteriormente doença de Chagas. A despeito da intensa controvérsia sobre essa descoberta científica, que ocorreu em 1909, ela se tornou um símbolo da medicina brasileira e da alta qualificação da ciência nacional (Kropf, 2009).

Na década de 1910, merecem destaque as viagens científicas promovidas pelo Instituto de Manguinhos em apoio às atividades da Inspetoria de Obras contra as Secas, com o objetivo de realizar o inventário das condições epidemiológicas e socioeconômicas das regiões percorridas pelo rio São Francisco e de outras áreas do Nordeste e do Centro-Oeste brasileiros. Entre elas, a que se tornou mais conhecida foi a de Arthur Neiva e Belisário Penna, dirigida a localidades situadas nos estados da Bahia, de Pernambuco, Piauí e Goiás.

No intervalo de sete meses, de março a outubro de 1912, os dois médicos foram responsáveis por amplo levantamento das condições de vida das populações locais, expressivo registro fotográfico e pelo relatório que se tornou uma referência para o movimento pelo saneamento rural na Primeira República (Santos, 2009; Santos, 1985; Hochman, 1998; Lima, 1999; Thielen et al., 2002). É à descoberta desse Brasil ignorado e doente pelas viagens médicas do Instituto Oswaldo Cruz e, em particular, à descoberta de Carlos Chagas, que alude uma das frases que se tornaram emblemáticas do movimento pelo saneamento dos sertões e da criação da Liga Pró-Saneamento do Brasil, em 1918: o Brasil como um imenso hospital, segundo a forte expressão utilizada por Miguel Pereira (Kropf, 2009; Sá, 2009). Segundo esses cientistas, as moléstias endêmicas representavam o maior obstáculo à construção da nacionalidade e ao progresso do país. A apatia do trabalhador rural, até então atribuída à raça, deveria ser explicada pela doença e, no caso de RoquettePinto, em grande parte, pelo analfabetismo. O sertão era definido pela doença 
generalizada e pela distância em relação aos poderes públicos. Note-se que Neiva, Penna e Roquette-Pinto tomariam parte, logo após essas viagens, do movimento pelo saneamento rural e da criação de novas instituições e agências estatais nas áreas de saúde, educação e ciência.

O retrato do país esboçado nesse e em outros textos apontava a doença - e não o clima e a raça - como o principal problema para o progresso das regiões. $\mathrm{O}$ atraso só poderia ser explicado pelo abandono a que eram relegadas as populações do interior do Brasil, o que nos leva a pensar em uma mudança sutil, porém significativa, em relação ao tema do isolamento do sertanejo proposto anteriormente por Euclides da Cunha. Para a difusão dessas ideias, muito contribuiu a publicação de artigos na imprensa, por Belisário Penna no jornal Correio da Manhã e por Monteiro Lobato em O Estado de S. Paulo. Os textos do primeiro foram republicados em 1918, no livro Saneamento do Brasil, porém a mais ampla divulgação decorreu dos escritos de Monteiro Lobato, reunidos em Problema Vital, no mesmo ano, com a inclusão do famoso texto sobre a regeneração de Jeca Tatu - um de seus personagens mais conhecidos, representativo dos pobres, sobretudo dos lavradores e outros trabalhadores rurais, na literatura brasileira (Lima, 2009).

No que se refere ao tema deste capítulo, também chamam a atenção as poucas referências às populações indígenas em relatórios de viagens realizadas a regiões e localidades marcadas pela sua presença. ${ }^{3} \mathrm{O}$ foco eram as populações sertanejas, como é possível verificar nos relatórios de viagem, à exceção já mencionada da Comissão Rondon, e sua divulgação na imprensa, assim como em livros de grande circulação para a época. Esses veículos contribuíram para a associação entre sertões e doenças de populações sertanejas, abordando apenas pontualmente a saúde e as condições de vida das populações indígenas.

Neste capítulo, interessa observar a forma como, a partir da divulgação dos relatos de viagem e da organização pelo movimento do saneamento dos sertões, construíram-se imagens duradouras sobre as populações rurais brasileiras que persistiram no debate intelectual e político das décadas seguintes. Essas fortes imagens continuaram a ser mobilizadas no debate intelectual e político sobre os rumos do país, tão bem sintetizadas na metáfora do "Brasil hospital" criada por Miguel Pereira (Sá, 2009). Tal retórica esteve presente no processo de centralização das políticas de saúde em nível federal, com a criação do Departamento Nacional de Saúde em 1920, e persistiu nas décadas que se seguiram, com a criação do Ministério da Educação e Saúde, em 1931, e do Ministério da Saúde em 1953 (Hochman, 1998; Hamilton G Fonseca, 2003; Lima, Fonseca G Hochman, 2005).

A análise de políticas de saúde para as populações indígenas requer que a relacionemos a essa discussão mais geral. Criou-se no início da República uma agência estatal específica para essas populações - o SPI - e se conformou em 1920 uma centralização maior das ações de saúde com a criação do Departamento 
Nacional de Saúde Pública. Uma possibilidade para explicar a ausência da questão indígena nas políticas nacionais de saúde até, pelo menos, a década de 1950 poderia ser encontrada nessa segmentação institucional. Contudo, tal explicação não nos parece suficiente, pois consideramos que um dos pressupostos da saúde pública consistiu na mudança das condições de saúde e de vida das populações sertanejas, ou, se quisermos reproduzir expressão corrente nas décadas de 1910 e 1920, na "redenção do homem sertanejo". Desse modo, mais do que resultado de uma segmentação institucional, a relativa invisibilidade da saúde indígena deve ser encontrada na relação complexa entre Estado, populações indígenas e concepções sobre nacionalidade. Tratava-se de construir o ideal de homem brasileiro tendo por base o caboclo, resultado da miscigenação entre o branco europeu e o indígena. A campanha pelo saneamento rural deixara na sombra as populações nativas.

\section{A Criação da Seção de Estudos e a Proposta de um Serviço Médico-Sanitário do SPI}

Parte integrante da regulamentação e dos objetivos primeiros do SPI, a questão da assistência sanitária ao índio não foi ao longo de sua atuação estruturada de forma regular e eficiente (Paz, 1994; Oliveira, 2008; Figueiredo, 2009). Entretanto, denúncias e registros sobre epidemias, falta de assistência às populações e fragilidade do SPI constavam nos relatórios e inquéritos realizados pelo Serviço, desde suas origens até, pelo menos, a década de 1950. Os problemas apontados consistiam na falta de material médico, de profissionais da saúde, além de constatações de prejuízos advindos do processo do contato entre índios e brancos dado o impacto do convívio entre eles. Desde a década de 1920, registrava-se naqueles documentos que a notável dificuldade sanitária enfrentada pelos grupos indígenas assistidos pelo SPI contribuiu largamente para o agravamento da diminuição demográfica indígena.

No início daquela década, o registro da mortalidade de crianças indígenas era feito no relato de chefes de inspetorias do SPI, como é o caso do relatório do chefe da Inspetoria do Serviço de Proteção aos Índios no Estado do Amazonas e Território do Acre (IR1), Bento M. Pereira de Lemos. Ao acompanhar os índices de mortalidade indígena na região, ele afirmou: "Era péssimo o estado sanitário de muitas regiões da Amazônia, onde faleciam muitas crianças" (Lemos 1921: 20, apud Freire, 2007).

As epidemias também eram apontadas como responsáveis por inúmeras mortes entre os indígenas, como evidencia o Relatório do Posto de São Jerônimo no ano de 1923: 
Em 1923 terrível surto de gripe epidêmica prostrou a todos os índios e exterminou não pequeno número dentre eles. (...) A causa da grande mortandade de índios por ocasião da epidemia foi principalmente pela desatenção que estes votam ao regime médico e dietético. Durante todo o ano de 1923 morreram, na povoação indígena S. Jerônimo, 39 índios, sendo 13 homens, 11 crianças e 6 mulheres. Em consequência da tuberculose 2 e outras doenças 7.4

Esse trecho do relatório traz à cena perspectivas sanitárias que vão além da contaminação e da falta de assistência médica. A transmissão de doenças infecciosas e parasitárias figura como parte das razões que levaram à morte de grande número dos índios atingidos pela gripe. As dificuldades para a introdução da medicina científica constituem outro tema importante nos registros do SPI. É importante ressaltar, ainda, que o discurso expresso no trecho mostra uma visão recorrente dos agentes da biomedicina da época, segundo a qual se tenta imprimir certa culpabilização a esses indígenas.

Quase duas décadas mais tarde, o inspetor Francisco Meireles, chefe das turmas de atração dos índios Xavante, em seu relatório dos trabalhos e atividades do setor Rio das Mortes durante o ano de 1945, apresentado ao diretor do SPI, José Maria de Paulo, afirmava:

Não posso deixar de lavrar meu protesto e manifestar minha indignação ante o estado de abandono em que fui encontrar estes índios que arrastam hoje uma existência infeliz. Frente ao que vi e descrevo nestas ligeiras linhas é que sugiro o envio de um médico e uma pequena farmácia de urgência a fim de examiná-los e providenciar hospitalização daqueles que sejam portadores de moléstias infectocontagiosas, tais como lepra, tuberculose, doenças venéreas e etc., bem como prescrever tratamento e cuidados a serem executados, com o fim de prevenir contágios e consequente propagação desses males. ${ }^{5}$

Durante a década de 1940, iniciativas importantes indicaram novas abordagens para a questão indígena. Em 1939 foi criado o Conselho Nacional de Proteção ao Índio (CNPI), diretamente vinculado ao Ministério da Agricultura (decreto-lei n. 1.794/1939). O CNPI configurava-se como um órgão normativo em relação ao SPI. 6 Os objetivos expressos em seu primeiro regulamento referiam-se a: "I - Promover e orientar estudos e investigações sobre as origens, línguas, ritos, tradições, hábitos e costumes dos índios (...) / IV - Dar ao SPI cooperação na realização da finalidade deste" ${ }^{7}$ Entre as propostas apresentadas àquele órgão, encontrava-se a sugestão do antropólogo Roquette-Pinto de criação de um serviço médico volante no sertão destinado à assistência aos indígenas e a trabalhadores rurais. ${ }^{8}$

A criação do CNPI ocorreu em um contexto marcado por conflitos relacionados à expansão das atividades econômicas, sobretudo na Região Centro-Oeste. Ainda que os textos constitucionais garantissem aos indígenas a posse das terras por 
eles ocupadas, a própria expansão de atividades agrícolas e pecuárias não poderia ocorrer sem que tais direitos fossem colocados em questão e se verificassem graves problemas em diversas localidades. No âmbito das políticas do governo federal, outra importante iniciativa com forte impacto na abordagem da questão indígena consistiu na criação da Fundação Brasil Central, vinculada ao Ministério da Agricultura, que promoveu expedições voltadas para o conhecimento e integração do território (Maia, 2012; Paiva, 2003; Paz, 1994). Em 1943, foi realizada a expedição Roncador-Xingu, que estava sob o comando do médico Noel Nutels e dos irmãos Villas-Boas e que teve como um de seus principais resultados o estabelecimento em 1946 do Parque Indígena do Xingu. Essa experiência foi importante para a criação dez anos mais tarde, sob a liderança de Noel Nutels, do Susa, vinculado ao Ministério da Saúde (Paz, 1994; Costa, 1987; Paiva, 2003).

No mesmo período, a abordagem da saúde indígena em tom de forte denúncia e solicitação de providências constava do relatório encaminhado ao Ministério da Agricultura por Modesto Dias da Cruz, diretor do SPI de 1947 a 1951:

já salientei que a assistência médica do SPI tem sido nula, considerando, portanto, essa minha ponderação como parecer supra. (...) Se a assistência médica aos índios não tem sido, até então, cuidada como medida essencial, não poderemos permanecer neste erro incompreensível que não paga a pena discuti-lo e sim resolvê-lo. ${ }^{9}$

Denúncias semelhantes à apresentada por Modesto Dias da Cruz eram constantes nos documentos dos dirigentes do SPI, quase sempre acompanhadas de demandas ao Ministério da Agricultura a fim de estabelecer ações sanitárias e assistenciais regulares, conforme se encontra, entre outros, no relatório de Vicente Vasconcelos, datado de 1930 (Souza Lima, 1995: 291). As constantes reivindicações dessa natureza indicam a fragilidade do SPI no âmbito do aparelho de Estado e também permitem breve digressão sobre as possibilidades de reconstituir sua história. É interessante notar que exatamente nessas fontes de caráter oficial - as quais, no caso de tantas instituições, tendem a neutralizar os aspectos negativos e as críticas - encontremos fortes evidências dos problemas constatados no contato entre os agentes do Estado e as populações indígenas.

Contudo, no período em exame neste estudo, verificamos ações e propostas que foram além da denúncia e demandas de um SPI fragilmente estruturado. Autores que o tomam como objeto de estudo são unânimes em afirmar que a década de 1940 apresenta-se como uma nova fase desse órgão, notadamente após a criação em 1942 da Seção de Estudos. Com ela intensificou-se o registro cinematográfico e documental das sociedades indígenas, além de seu estudo etnológico (Figueiredo, 2009; Oliveira, 2008; Souza Lima, 1995; Oliveira, 1978), como disposto em seu regulamento, tratava-se de "documentar, através de pesquisas etnológicas e 
linguísticas, de registros cinematográficos e sonográficos, todos os aspectos das culturas indígenas, orientando suas atividades de modo a proporcionar diretrizes científicas à ação assistencial do SPI" ${ }^{10}$

A partir de 1944, sob a direção de Herbert Serpa (1944-1951),11 a Seção de Estudos do SPI assume uma nova orientação que, além de preconizar a realização de estudos de cunho etnológico, postulava a necessidade de enfrentar as questões sanitárias relativas ao contato entre civilizados e indígenas. No final de 1946, Serpa propôs a criação de um Serviço Médico-Sanitário do SPI para o ano de 1947,12 iniciativa apontada por Souza Lima (1995) como resultante de uma tentativa de ampliação do espectro da assistência prestada por esse órgão. O Serviço Médico tinha como ponto de partida algumas considerações acerca da ausência de dispositivos específicos que dessem conta da saúde indígena no âmbito do Departamento Nacional de Saúde (DNS). Segundo o autor do documento, o Regimento do DNS do Ministério da Educação e Saúde do Brasil, baixado pelo decreto n. 8.674/1942, apresentava apenas implicitamente a questão sanitária das sociedades indígenas, como nas expressões "saneamento rural" e ainda no trecho: "planejar e orientar, em todo o país (...) a luta contra doenças degenerativas e outras entidades mórbidas para as quais não haja serviços especializados do DNS" (Museu do Índio, 1946 apud DNS, 1942). Herbert Serpa segue apontando as deficiências desse regulamento do DNS no tocante às especificidades culturais dos indígenas, os quais, segundo ele, não poderiam ser assistidos nos mesmos moldes dos civilizados, "em virtude dos estágios culturais diferentes em que se encontram os índios em relação aos civilizados em geral".13

O chefe da Seção de Estudos destacava ainda a falta de cuidado com a atenção à saúde no âmbito do SPI. Em suas palavras: "o espírito que tem predominado nos trabalhos do SPI, de modo geral, é mais de ordem econômico-administrativo que de qualquer outra espécie". ${ }^{14}$ Em conclusão a essa primeira parte do documento, Herbert Serpa afirma que "embora os problemas de ordem médico-sanitária dentro das atividades do SPI tenham sido cuidados, não o foram sob as determinações de um regimento sanitário, nos moldes básicos do DNS". 15

A proposta de organização de um serviço médico do SPI foi considerada, então, inédita na história administrativa desse órgão: "Segundo crê esta S.E., os problemas deste gênero (médico-sanitário) têm sido resolvidos segundo a eventualidade. Nem esta chefia já teve conhecimento de qualquer plano geral para a solução do assunto". ${ }^{16}$

Quanto à organização do Serviço Médico-Sanitário, destaca-se a localização da sede, no Rio de Janeiro, sede também do SPI. Para Herbert Serpa, a proximidade entre as chefias ajudaria na comunicação e na administração. No Rio de Janeiro ficaria a superintendência do Serviço, sob responsabilidade de um médico chefegeral. E cada inspetoria ${ }^{17}$ teria como responsável um médico chefe regional, além 
de um corpo técnico auxiliar, que contaria com enfermeiros homens e mulheres de acordo com a necessidade do posto.

É importante observar que o documento mencionado refere-se a um esboço para a organização de um serviço médico do SPI, um esforço dirigido por uma equipe formada por médicos, com especialização em medicina indígena - para o que seriam necessários conhecimentos antropológicos. Com efeito, o Serviço Médico que viria a ser organizado na década de 1950 no âmbito da Seção de Orientação e Assistência revelou-se bem mais limitado do que preconizava o documento mencionado. De sua criação decorreu o estabelecimento de pequenas farmácias nos postos indígenas e, em alguns deles, a assistência de uma enfermeira (Figueiredo, 2009: 183).

No plano elaborado por Herbert Serpa, a assistência médica, sugerida pelo Serviço, deveria estar de acordo com a Divisão de Organização Sanitária do DNS, apresentando, entretanto, formulação de práticas sanitárias específicas para os indígenas, segundo orientação da Seção de Estudos do SPI. Tais especificidades, a serem observadas, não caracterizavam questionamento à medicina ocidental, como afirma o documento no trecho a seguir:

A medicina preventiva e curativa que convém aos índios deve ser considerada em geral como uma especialidade. É naturalmente coparticipante da medicina civilizada, em todos os processos e técnicas de identificação ou diagnose e da arte da terapêutica, uma vez que o espírito do Serviço Médico do SPI que incide nos conflitos culturais eventuais, nesse campo, tende a firmar-se em favor da medicina civilizada, como é natural. ${ }^{18}$

No tópico "Sugestões", Herbert Serpa faz menção a dois temas importantes para nossos propósitos:

III - Dada a existência de grupos indígenas nos mais diversos pontos do território nacional brasileiro, em contato ou não com as populações civilizadas das zonas rurais, sertanejas desertas, nestas últimas através de contatos eventuais com trabalhadores da agricultura extrativa, ou com os componentes das missões científicas, seria errôneo dizer-se que os problemas médicos dos Índios se enquadram apenas no grupo das doenças tropicais. ${ }^{19}$

O segundo tema refere-se à preparação dos médicos que participariam desse Serviço, pois segundo ele deveriam se especializar em etnologia, a fim de melhor compreenderem os problemas médico-sanitários das sociedades indígenas, além de resolver conflitos possíveis entre doentes e o médico:

IV - Nas áreas indígenas sob o controle dos Postos Indígenas do SPI os problemas médico-sanitários devem ser estudados à luz dos padrões sanitários brasileiros, não obstante exigirem médicos que para isto se especializam no trato dos problemas etnográficos, ou melhor, da nova antropologia cultural. ${ }^{20}$ (grifos nossos) 
Tratava-se, sobretudo, de levar em conta a concepção de doença do silvícola para que o médico pudesse empreender uma prática persuasiva. No referido documento, há a seguinte afirmativa:

São inegáveis as profundas diferenças e divergências existentes entre a Medicina Indígena e a dos civilizados; enquanto aquela se baseia em falso e primitivo conceito de vida, e se exerce empiricamente através de práticas supersticiosas e mágicas, a dos civilizados se baseia em técnicas e métodos científicos experimentais sob a condição da moral civilizada cujos valores se tornam incomparáveis àqueles dos primitivos silvícolas. ${ }^{21}$ (grifo nosso)

Tal concepção sobre a instrumentalidade do conhecimento antropológico na afirmação da medicina científica e no suporte a ações sanitárias encontra paralelo em programas de saúde pública orientados pelo que se denominava, na época, mudança social provocada ou dirigida, nos contextos da Segunda Guerra Mundial, do pós-guerra, da Guerra Fria e do processo de descolonização. Entre tais programas e iniciativas, os quais não se restringiram à experiência brasileira, está o Serviço Especial de Saúde Pública (Sesp), que, criado em 1942 por um acordo de cooperação entre os governos brasileiro e norte-americano, teve nas ações de cientistas sociais sobre a educação sanitária de populações rurais uma de suas mais marcantes características (Campos, 2006; Maio G Lima, 2009; Figueiredo, 2009; Cardoso, 2009; Lima G Maio, 2010). Nas palavras de José Arthur Rios (2006), que na década de 1950 dirigiu a seção de pesquisa social do Sesp, ao cientista social cabia atuar como um tradutor da cultura do assistido nos termos do grupo cultural que o administrador representava. Guardadas as diferenças entre as representações então predominantes sobre as populações rurais e as indígenas, verificamos a mesma tendência de se pensar a saúde como um valor externo às populações, que são objeto das políticas do Estado.

Entretanto, a vinculação entre os conhecimentos antropológicos e as ações de saúde verificada no SPI após a criação da Seção de Estudos não ocorreu sem tensões e vozes dissonantes no que concerne às visões sobre saúde indígena e os efeitos do contato interétnico, conforme abordaremos mais à frente.

Foram preocupações dessa natureza - e não apenas o registro etnográfico das manifestações culturais das sociedades indígenas - que estiveram na origem da contratação dos primeiros antropólogos pelo SPI. Um dado importante no contexto intelectual da década de 1940 consistiu na formação especializada de antropólogos pela Escola Livre de Sociologia e Política (ELSP), criada em 1933 (Limongi, 1989; Figueiredo, 2009; Oliveira, 2010). No campo da etnologia lecionada nessa instituição, Herbert Baldus despontou como importante referência e se caracterizou, conforme observaram Passador (2002) e Figueiredo (2009), por um viés político no qual se associou a defesa de estudos culturais a uma ação indigenista que buscasse 
solução para os problemas verificados no contato. Entre os jovens que concluíram o mestrado na ELSP sob a orientação de Baldus, estava Darcy Ribeiro, que viria a desempenhar papel relevante no SPI durante a década de 1950.

\section{Darcy Ribeiro e o Tema da Redução Demográfica}

Em 1947, a Seção de Estudos contratou no cargo de naturalista - o único então existente, uma vez que não havia carreira específica para cientistas sociais no Estado - o linguista Max Boudin e o antropólogo Darcy Ribeiro (Figueiredo, 2009). Foi assim que o último passou a realizar numerosos trabalhos de cunho etnológico acerca das populações assistidas por esse serviço. $\mathrm{Na}$ dupla condição de autor e ator do processo de reconhecimento do indígena brasileiro, Darcy Ribeiro nos ofereceu importantes referências sobre essas populações e suas relações com a política e a sociedade brasileira do período, sobretudo no que tange à criação e ao funcionamento do SPI. A contribuição de Darcy Ribeiro como funcionário do SPI ultrapassou os limites institucionais, com a ampla divulgação dos problemas decorrentes da relação entre indígenas e sociedade nacional, especialmente no que concerne à questão da redução demográfica, denunciada em artigos e documentos oficiais dessa entidade.

Um dos artigos mais emblemáticos sobre essa questão foi publicado em 1956 e, posteriormente, como capítulo do livro Os Índios e a Civilização, em 1970, com o título "Convívio e contaminação". Nele, Darcy Ribeiro (1970) apresentou diversos fatores que estariam levando à crescente depopulação de grupos inteiros de índios do Brasil. Um dos aspectos centrais do texto do antropólogo refere-se ao efeito nocivo do contato entre contato entre índios e brancos, considerando que os que se encontravam em melhores condições de vida eram exatamente os que menos se aproximaram dos civilizados.

A análise ultrapassa as questões vinculadas a uma possível fragilidade biológica dessas populações e lança mão de temas caros à antropologia, como a questão cultural e o sistema de parentesco concernente a cada sociedade específica, por exemplo. Ou seja, para Darcy Ribeiro, além das moléstias trazidas pelos civilizados, as novas formas de organização social e econômica, muitas vezes impostas às sociedades indígenas, provocariam a desestruturação delas, podendo levá-las à extinção. Importante destacar que seus estudos não se limitaram a constatações de epidemias ou à produção de dados estatísticos acerca das populações indígenas visitadas; sua preocupação estava em compreender os efeitos que a crescente redução demográfica provocaria nesses grupos. O autor destacou que os efeitos dissociativos da depopulação poderiam ser verificados mesmo depois de passadas as primeiras epidemias que a ocasionaram, tão profundas as transformações que 
provocava, tais como alterações na distribuição e nas inter-relações dos vários grupos locais, na organização familiar, no casamento - enfim, em todas as instituições sociais (Ribeiro, 1970).

Darcy Ribeiro citou ao longo do artigo alguns exemplos de sociedades desestruturadas em razão da diminuição de sua população. Foi o caso dos Kaingáng paulistas, que, durante a década de 1910, no momento de construção da estrada de ferro Noroeste do Brasil, viveram numerosas situações de conflito. Além disso, em razão da enorme mortalidade provocada pelas epidemias, viram-se impossibilitados de obter cônjuges, ocasionando a prática do incesto - o que feria a estrutura familiar e simbólica da sociedade indígena e também as determinações morais da equipe do SPI, que procurou manter severa vigilância sobre os índios, como determinara o médico Horta Barbosa, chefe do posto onde viviam os Kaingáng. Outras questões referentes aos problemas ocasionados pela redução demográfica são apresentadas pelo autor, como os prejuízos ligados à prática da agricultura, ou quaisquer formas de economia de subsistência - o que, segundo Darcy Ribeiro, ampliou nos índios o sentimento de dependência em relação ao SPI.

Diante desse quadro calamitoso enfrentado pelas populações indígenas, as conclusões se apresentavam de forma fatalista. O autor fez previsões de uma redução progressiva da população indígena, à medida que esta passa da condição de isolamento para a condição de integrada; apontou também a progressiva modificação das línguas e da estrutura cultural indígena e afirmou ainda que a sobrevivência nas sociedades indígenas "somente se fará possível através de um esforço de assimilação como etnias minoritárias dentro de um novo contexto étnico nacional multiétnico, mais capacitado a assegurar liberdade e bem-estar a seus componentes" (Ribeiro, 1970: 445-446).

As fontes analisadas para a composição da análise de Darcy Ribeiro (1970) são diversas e divididas por ele entre fontes teóricas; ensaios temáticos; monografias; estudos etnológicos, levantamentos regionais e estudos de indigenistas, estes dois últimos em sua maioria advindos de expedições patrocinadas pelo SPI ou vinculadas a ele. Entre as últimas fontes, destaca-se o inquérito promovido pelo SPI sobre o estado de nutrição entre os Xavante, realizado em 1954 por Amaury Sadock, médico-sanitarista vinculado à Prefeitura do Distrito Federal, em que se encontram importantes observações:

De fato a civilização, com todos os seus problemas alimentares de colheita, transporte, estocagem, preparo e etc., faz com que haja diminuição do valor nutritivo do alimento, ocasionando uma série de doenças por carência (...). Vamos, portanto, apelar junto às autoridades encarregadas da Proteção ao Índio, para que não introduzam no meio aborígene este mal da civilização: o uso abusivo das balas, doces, etc. a fim de que não se repita aqui o que tem sucedido com todas as outras tribos de hábitos primitivos, onde a alimentação dos civilizados foi introduzida com o 
aumento crescente de cáries dentárias e deficiências nutricionais (...). Estas são as conclusões a que chegamos de acordo com a opinião do Dr. Newton Braga de Oliveira, médico e nutrólogo da Prefeitura do Distrito Federal. ${ }^{22}$

É igualmente relevante o relatório do médico Leão da Mota em 1955, também sobre os Xavante:

Mais de uma vez tivemos a dolorosa oportunidade de verificar a tribo indígena sendo dizimada pela nossa civilização com as armas mais ofensivas e de maior poder de destruição para ela - vírus e bacilos, acompanhados do aliado natural, a fome. O índio Xavante está em fase de economia de coleta e não possui armazenamento em proporções satisfatórias de artigos de consumo alimentar. A atividade muscular que a coleta exige (...) fica interrompida desde que os indivíduos são atingidos por processos infecciosos, como é natural. Qualquer epidemia, mesmo a de simples gripe, (...) assume caráter catastrófico pela impossibilidade de atingir os alimentos para si e os seus. A subalimentação diminui a resistência orgânica para a luta contra os germes. ${ }^{23}$

Como observaram outros autores, Darcy Ribeiro teria politizado a problemática do contato entre índios e brancos, chamando a atenção para o etnocídio escondido sob esse termo aparentemente neutro. Seus trabalhos ressaltaram os aspectos problemáticos do contato, relacionando-o à expansão da fronteira interna do Estado nacional (Ramos, 1990; Viveiros, 1958). Durante a gestão de José Maria da Gama Malcher no SPI (1950-1954), o antropólogo assumiu a direção da Seção de Estudos, na qual ingressaram Roberto Cardoso de Oliveira e Mário Ferreira Simões. No mesmo período, Eduardo Galvão foi integrado à Seção de Orientação e Assistência (Figueiredo, 2009).

Conforme assinalou Mauro de Almeida (2004), Darcy Ribeiro, Eduardo Galvão e Roberto Cardoso de Oliveira desempenharam papel central na constituição de uma linha de estudos sobre contato interétnico, desenvolvendo uma etnografia que acentuou os conflitos da sociedade nacional diante das frentes de expansão do capitalismo (Almeida, 2004). No caso de Cardoso de Oliveira, o conceito de fricção interétnica veio a exercer notável influência nos estudos antropológicos que privilegiaram o tema do contato na abordagem das sociedades indígenas (Peirano, 1995). A experiência vivida nos anos 1950 na Seção de Estudos do SPI, ao lado da formação especializada nas instituições universitárias criadas na década de 1930, constituiu, assim, base importante para a consolidação do campo de estudos etnográficos no país.

Nessa perspectiva, a criação do Museu do Índio, em 1953, e a experiência do Curso de Aperfeiçoamento em Antropologia Cultural, nos anos de 1955 e 1956, são também indicadores expressivos desse momento de forte relação entre o SPI e a constituição do campo da antropologia. Note-se que dentre os objetivos do curso 
constava a formação de quadros técnicos para instituições de desenvolvimento regional, o Centro de Pesquisas Educacionais e o Serviço Especial de Saúde Pública. Coordenado por Darcy Ribeiro, dele participaram como professores Roberto Cardoso de Oliveira, Eduardo Galvão, José Bonifácio Rodrigues, Kalervo Oberg, Luiz de Castro Faria, Luiz Aguiar da Costa Pinto e Joaquim Mattoso Câmara Jr. (Mattos, 2007).24 O curso era dividido em duas partes: o primeiro período de trabalhos e estudos no Museu do Índio; e o segundo e último período no campo para a realização da pesquisa, com duração de três meses. ${ }^{25}$ Como um dos temas analisados, a questão da saúde indígena integrou essa agenda de ensino e pesquisa, constituindo o principal objeto do trabalho final do curso de José Moretzsohn de Andrade. Moretzsohn realizou um estudo acerca da assistência sanitária prestada aos índios pelo SPI, evidenciando o grave quadro sanitário das populações envolvidas e propondo medidas para solucionar o problema. ${ }^{26}$

Nesta reflexão em torno da saúde indígena, o tema do "convívio e contaminação" sugerido por Darcy Ribeiro nos leva ainda a um interessante problema. As ciências sociais durante as décadas de 1940 a 1960 lidavam com a questão da modernização e o desenvolvimento, mas, sobretudo, com o tema das resistências culturais à mudança (Villas-Bôas, 2006). Expressivo de tal concepção foi o seminário Resistências à Mudança: fatores que impedem ou dificultam o desenvolvimento, promovido pelo Centro Latino-Americano de Pesquisas em Ciências Sociais em outubro de 1959. Na introdução aos anais do evento, seu diretor, o sociólogo Luiz de Aguiar Costa Pinto, observou:

O primeiro fator que impede ou dificulta o desenvolvimento que se tomou para estudo refere-se aos problemas de integração de populações atrasadas à economia e à sociedade que se desenvolve. Na América Latina, foco do nosso interesse, populações indígenas, migrantes rurais-urbanos, imigrantes vindos de outras partes do mundo, gerações que envelhecem, força de trabalho não qualificada, são fatores que dificultam a integração social e a formação da mão de obra de que o desenvolvimento essencialmente depende. (Costa Pinto, 1960: 10)

No que concerne à saúde nas discussões em torno das resistências culturais à mudança, ganhou relevo o tema de uma medicina rústica, atualizando as discussões sobre o isolamento das populações caboclas ou sertanejas, que, como brevemente aqui mencionamos, remontavam ao início do século XX. Se o isolamento/ abandono era apontado como principal problema das populações caboclas ou sertanejas - doentes porque abandonadas à própria sorte -, no caso das populações indígenas foi exatamente o contato que começou a ser enfatizado como explicação para seus problemas médico-sanitários. Por sua vez, indígenas e populações sertanejas compartilhavam o mesmo problema da ausência ou incipiência de atenção pública à saúde, conforme evidenciam diferentes fontes, inclusive a documentação 
relativa ao SPI e a pesquisa sobre medicina popular no vale do São Francisco, realizada pelo antropólogo Alceu Maynard em fins da década de 1940 (Araújo, 1979; Oliveira, 2010).

No caso dos indígenas, os principais problemas abordados referiam-se à falta de material médico e de profissionais qualificados para o exercício da assistência médica, como também demonstrou o inquérito médico-sanitário entre os Xavante, realizado em 1954 por Amaury Sadock Filho, sobre a situação do Posto Indígena de Atração (PIA) Pimentel Barbosa: "Serviços médicos e farmacêuticos: limitam-se à assistência de uma enfermeira e uma pequena farmácia". ${ }^{27}$ Ainda neste inquérito, agora acerca da região da Aldeia Apoena: "Não possui a aldeia nenhum serviço médico. Segundo observamos, aceitam os indígenas facilmente qualquer espécie de medicamentos, inclusive injeções. Eles mesmos solicitam tais serviços, principalmente quando visitam o PIA" ${ }^{28}$

Observações similares às de Sadock Filho são frequentes em outras fontes, inclusive em muitas referidas às populações sertanejas, e parecem indicar que o acesso à medicina e à terapêutica científicas levaria à substituição das práticas de cura tradicionais. Contudo, conforme observaram Oliveira (2008) e Figueiredo (2009), o processo era bem mais complexo e, muitas vezes, verificou-se resistência à medicalização e às orientações dietéticas. ${ }^{29}$

As reiteradas referências à precariedade da assistência prestada aos indígenas têm continuidade mesmo com o estabelecimento de convênios firmados com diversas agências, como a Divisão de Organização Sanitária do Ministério da Saúde, o Sesp, o Serviço Nacional de Tuberculose, o Instituto Oswaldo Cruz e o Departamento Nacional de Endemias Rurais (DENERu) (Figueiredo, 2009). No caso desta última agência, o convênio assinado em 1958 foi precedido pela proposta elaborada por João Leão da Motta um ano antes, na qual ele apontava diretrizes para assistência médica entre os silvícolas assistidos pelo SPI. Seriam de responsabilidade da DENERu:

a) Assistência às endemias em que o DENERu já possui postos instalados

b) Endemias de responsabilidade de outros serviços nacionais e que instituem problemas clínicos importantes de patologia indígena

c) Assistência clínica não especificada

d) Assistência hospitalar domiciliar

e) Assistência médico-sanitária em epidemias

f) Vacinação preventiva e assistência medicamentosa ${ }^{30}$

É interessante observar que João Leão da Motta era chefe da circunscrição do DENERu na região em que estava sendo construída a nova capital; tinha como uma das principais preocupações o controle e o tratamento da malária nas áreas que seriam cortadas pela rodovia Belém-Brasília (ver também o capítulo 3 deste 
volume). Conforme já havia ocorrido em outros momentos de ocupação do interior do país, a questão indígena, com os problemas de epidemias e desestruturação social, ganhava proeminência à medida que se acentuavam os fluxos migratórios para o Centro-Oeste e o Norte, e esse foi um dos temas, nem sempre visíveis na literatura, presentes na construção da moderna capital no sertão.

Outra ação, realizada no governo Kubitschek, é relatada nas análises realizadas por historiadores e cientistas sociais como a primeira iniciativa estruturada de organizar um serviço regular de assistência à saúde indígena: a criação do Serviço de Unidades Sanitárias Aéreas (Susa), em 1956 (Paz, 1994; Costa, 1987; Paiva, 2003). O serviço, visto como o resultado dos esforços do médico-tisiologista Noel Nutels, não se restringiu às ações de combate à tuberculose e foi considerado também pelos analistas que sobre ele escreveram na década de 1950 como a iniciativa de impacto mais positivo, sobretudo no combate a epidemias. Esses analistas chamavam a atenção para a dispersão dos núcleos indígenas, a dificuldade de acesso e os benefícios do transporte aéreo (Ribeiro, 1970). Noel Nutels, de 1963 a 1964, viria a dirigir o SPI, por indicação de Darcy Ribeiro, quando este último ocupava o cargo de chefe da Casa Civil no governo João Goulart. ${ }^{31}$

O período de atuação de Darcy Ribeiro no SPI suscita uma série de discussões, porém o mais importante para os propósitos deste capítulo é acentuar um tema ainda pouco explorado na literatura sobre política indigenista no país: as relações entre território, constituição do Estado nacional e imaginação social e política sobre o Brasil, incluindo sob esse rótulo amplo a produção das ciências sociais. Em linhas gerais, trata-se de discutir as relações entre ideias e práticas estatais, indicando a pertinência de se tomar como objeto de estudo agências do Estado para a análise da produção e circulação de ideias de longa duração na história social e política do país. ${ }^{32}$ Este é certamente o caso do SPI, em particular no período delimitado em nosso estudo, quando o contato interétnico e a saúde indígena se tornaram efetivamente um problema de pesquisa e de política pública.

\section{A Questão Indígena no Brasil: novos olhares}

As décadas de 1940 e 1950 representaram um importante capítulo na história da questão indígena no Brasil; um ponto de encontro entre concepções médicas e perspectivas antropológicas. Ao abordar o tema neste estudo, procuramos demonstrar que o SPI - e as iniciativas adotadas pela Seção de Estudos desse órgão - constitui-se em expressão de forças sociais presentes naquele contexto e também em agência, com papel ativo na produção de ideias e matrizes de interpretação. Nessa perspectiva, foi fundamental apresentar a concepção de Herbert Serpa ao estruturar um plano para a criação de um serviço médico-sanitário do SPI, 
em 1947, e as discussões posteriormente propostas por Darcy Ribeiro em torno do problema por ele denominado redução demográfica.

Para a análise das ideias e das propostas de políticas públicas referidas à saúde indígenas, elaboradas no período em pauta, consideramos necessário situá-las inicialmente em um processo histórico de mais longa duração e entendê-las como expressão de dois fenômenos interligados: A criação do Serviço de Proteção aos Índios e de Localização de Trabalhadores Nacionais, em 1910, transformado oito anos mais tarde em Seviço de Proteção ao Índio, e do Departamento Nacional de Saúde, em 1920, com sua ênfase no saneamento rural e na saúde das populações sertanejas.

Na percepção de médicos e intelectuais, as populações sertanejas foram vistas como vítimas de isolamento e abandono por parte do Estado, algo que chegou a ser descrito pela socióloga Maria Isaura Pereira de Queiroz (1973) como o "mito do isolamento do sertanejo". Em contraste, sobretudo a partir da década de 1950, com a divulgação e a politização da redução demográfica, o contato interétnico passaria a ser apontado como o principal problema a ser enfrentado no que dizia respeito à saúde indígena.

É em relação a tal matriz de pensamento sobre a constrição da nacionalidade que situamos a nossa análise sobre as propostas de assistência à saúde no SPI e a dificuldade para torná-la efetivamente um tema de política pública. Conforme demonstramos, referências a problemas representados por epidemias, a exemplo de surtos de sarampo e de gripe, são constantes nos relatórios dos postos do SPI. Sem dúvida, as grandes distâncias geográficas e as dificuldades de acesso às áreas de população indígena, dispersas pelo interior do país, ofereciam às equipes do SPI um obstáculo real e, por vezes, intransponível. No entanto, a falta de organização sanitária nos postos do SPI, associada à ausência constante de pessoal qualificado para o atendimento aos indígenas, provocava uma situação ainda mais calamitosa em relação à atenção à saúde dessas populações. As necessidades verificadas desde os primeiros anos de atuação do SPI foram sistematizadas por Herbert Serpa, em 1947, na estruturação de um plano para a criação de um serviço médico-sanitário, e continuaram a ser apontadas nas décadas seguintes.

As denúncias presentes nos documentos oficiais do SPI, o quadro dramático esboçado pelos inquéritos sanitários de chefes de postos, ao lado de suas observações próprias em pesquisa de campo, constituíram fontes importantes para a análise realizada por Darcy Ribeiro na década de 1950. A experiência vivida sob sua direção na Seção de Estudos do SPI, além da formação especializada nas instituições universitárias criadas na década de 1930, constituiu, conforme argumentamos, base importante para a consolidação do campo de estudos etnográficos voltados para as populações indígenas no país. Nessa perspectiva, a criação do Museu do Índio, em 1953, e a experiência do Curso de Aperfeiçoamento em Antropologia Cultural, 
nos anos de 1955 e 1956, são também indicadores expressivos desse momento de forte relação entre o SPI e a constituição do campo da antropologia. O período da história da saúde indígena aqui descrito pode também ser lido como um relevante momento da história das ciências sociais no Brasil.

\section{Notas}

1 Na tese de Regia Érika Figueiredo, a participação dos antropólogos no SPI, no período de 1947 a 1964, é discutida em seção específica do capítulo sobre a antropologia e a agenda da saúde pública no Brasil.

2 O Serviço de Proteção aos Índios e Localização dos Trabalhadores Nacionais (SPILTN), criado pelo decreto n. 8.072/1910, vinculado ao Ministério da Agricultura, passa a se chamar apenas Serviço de Proteção aos Índios (SPI) a partir de 1918. O SPI apresenta-se como a primeira instituição governamental brasileira direcionada para a causa indígena.

3 Referências às populações indígenas, ainda que pontuais, podem ser encontradas no relatório da viagem realizada por Carlos Chagas ao vale do rio Negro em 1913 (Schweikardt G Lima, 2007). Um dos textos referidos a viagens elaborados por médicos que mais se debruçaram sobre as condições de vida de sociedades indígenas foi o de Julio Paternostro - Viagem ao Tocantins (Lima, 2009). O livro desse médico, publicado pela coleção Brasiliana, foi saudado, no contexto de sua publicação, pelo sociólogo Florestan Fernandes (1979), entre outras razões, por chamar a atenção para os problemas das sociedades indígenas, tema que considerava praticamente invisível na historiografia brasileira.

4 Relatório do Posto São Jerônimo de 1923. Museu do Índio, Funai, microfilme 380, fotograma 0002.

5 Relatório do Inspetor Francisco Meireles de 1945. Museu do Índio, Funai, microfilme 381, fotograma 0306.

6 Sobre o CNPI, ver Freire $(1990,1996)$.

7 Museu do Índio, Funai, 1953, microfilme 2B, fotogramas 2.145-2.201.

8 Carta de Rondon a Roquette-Pinto, 28/VII/1941. Acervo da Academia Brasileira de Letras.

9 Relatório de gestão de Modesto Dias da Cruz, 1947. Museu do Índio, Funai, microfilme 1A, fotograma 4.219 .

10 Regimento do SPI de 1942, art. 8º, alínea h. Museu do Índio, Funai.

11 A contratação de Herbert Serpa em 1944 se deu na forma de cargo comissionado e não como funcionário do Ministério da Agricultura. Sua contratação efetiva ocorreu em março de 1947. Sobre a contratação de Serpa, ver Ione Couto (2005) e o microfilme 374, fotograma 0024, Serviço de Arquivo do Museu do Índio (RJ).

12 Plano do Serviço Médico para 1947. Museu do Índio, Funai, microfilme 1A, fotogramas 4.207 a 4.224 . 
13 Plano do Serviço Médico Sanitário, 1946. Museu do Índio, Funai, microfilme 1A, fotograma 4.212 .

14 Plano do Serviço Médico Sanitário, 1946. Museu do Índio, Funai, microfilme 1A, fotograma 4.212 .

15 Plano do Serviço Médico para 1947. Museu do Índio, Funai, microfilme 1A, fotogramas 4.212.

16 Plano do Serviço Médico para 1947. Museu do Índio, Funai, microfilme 1A, fotogramas 4.212.

17 As inspetorias a que o texto se refere são: IR1-Manaus, IR2-Belém, IR3-São Luís, IR4-Recife, IR5-Campo Grande, IR6-Cuiabá, IR7-Curitiba, IR8-Goiânia, IR9-Porto Velho.

18 Plano do Serviço Médico para 1947. Museu do Índio, Funai, microfilme 1A, fotograma 4.215.

19 Plano do Serviço Médico para 1947. Museu do Índio, Funai, microfilme 1A, fotograma 4.213.

20 Plano do Serviço Médico para 1947. Museu do Índio, Funai, microfilme 1A, fotograma 4.213.

21 Plano do Serviço Médico para 1947. Museu do Índio, Funai, microfilme 1A, fotograma 4.215.

22 Inquérito sanitário realizado por Amaury Sadock Filho em 1954. Museu do Índio, Funai, microfilme 381, fotogramas 00000-00331.

23 Relatório de Leão da Mota, 1955. Museu do Índio, Funai, microfilme 380, fotograma 0164.

24 Sobre o Curso de Aperfeiçoamento em Antropologia Cultural (CAAC) ministrado do Museu do Índio, ver Mattos (2007).

25 Ver Relatório do SPI de 1956. Museu do Índio, Funai, microfilme 381, fotogramas 2.089-2.102.

26 Ver Relatório do SPI de 1956. Museu do Índio, Funai, microfilme 381, fotogramas 2089-2102.

27 Inquérito sanitário realizado por Amaury Sadock Filho em 1954. Museu do Índio, Funai, microfilme 381, fotogramas 00000-00331.

28 Microfilme 381, fotograma 00000-00331, Museu do Índio, Funai, 1954.

29 A literatura nas últimas décadas vem-se dedicando à questão dos sistemas biomédicos em contraponto aos sistemas tradicionais. Sobre o tema, ver Jean Langdon (2004).

30 Planejamento para a execução do convênio realizado entre o DENERu e o SPI, 1957. Museu do Índio, Funai, microfilme 381, fotograma 0467.

31 Em fins da década de 1950, Darcy Ribeiro deixou o SPI e deu início a uma atuação política na área de educação e que teve como marco a criação do Centro Brasileiro de Pesquisas Educacionais em 1955. Sobre a trajetória do antropólogo, ver Bomeny (2001).

32 Contribuição relevante, ainda que não tenha como foco a gênese e a circulação de ideias, é o já citado estudo de Souza Lima (1995) sobre a política indigenista no Brasil. Para a discussão de natureza mais geral sobre território, Estado e imaginação social, consultar o livro de João Marcelo Maia (2012) sobre o caso da Fundação Brasil Central. 
ALMEIDA, M. W. B. A etnografia em tempos de guerra: contextos temporais e nacionais da definição do objeto da antropologia. In: PEIXOTO, F. A.; PONTES, H. G SCHWARCZ, L. (Orgs.). Antropologias, Histórias, Experiências. Belo Horizonte: Editora UFMG, 2004.

ARAúJO, A. M. Medicina Rústica. \#. ed. São Paulo: Ed. Nacional, 1979. (Coleção Brasiliana, v. 300)

BARROSO-HOFFMAN, M. et al. A administração pública e os povos indígenas. In: FALEIROS, V.; NUNES, S. G FLEURY, S. (Orgs.). A Era FHC e o Governo Lula: transição? Brasília: Inesc, 2004.

BOMENY, H. Darcy Ribeiro: sociologia de um indisciplinado. Belo Horizonte: Editora UFMG, 2001.

CAMPOS, A. L. V. Políticas Internacionais de Saúde na Era Vargas: o Serviço Especial de Saúde Pública, 1942-1960. Rio de Janeiro: Editora Fiocruz, 2006.

CARDOSO, J. L. R. Educando os Educadores: ciências sociais e educação sanitária na experiência do Sesp (1950-1960), 2009. Tese de Doutorado, Rio de Janeiro: Casa de Oswaldo Cruz, Fundação Oswaldo Cruz.

COSTA, D. C. Política indigenista e assistência à saúde: Noel Nutels e o Serviço de Unidades Sanitárias Áereas. Cadernos de Saúde Pública, 4(3), 338-401, 1987.

COSTA PINTO, L. A. Resistências à Mudança: fatores que impedem ou dificultam o desenvolvimento. Rio de janeiro: Clapcs, 1960.

COUTO, I. H. P. Darcy e os Urubu: um caso entre colecionador e coleção, 2005. Dissertação de Mestrado, Rio de Janeiro: Universidade Federal do Estado do Rio de Janeiro (Unirio).

CUNHA, M. C. (Org.). História dos Índios no Brasil. São Paulo: Companhia das Letras, 1992.

DEPARTAMENTO NACIONAL DE SAÚDE (DNS). Relatório anual, 1942.

FERNANDES, F. Mudanças Sociais no Brasil. 3. ed. São Paulo: Difel, 1979.

FIGUEIREDO, R. E. D. Histórias de uma Antropologia da Boa Vizinhança: um estudo sobre o papel dos antropólogos nos programas de assistência técnica e saúde no Brasil e no México (1942-1960), 2009. Tese de Doutorado, Campinas: Universidade Estadual de Campinas.

FREIRE, C. A. R. Indigenismo e Antropologia: o Conselho Nacional de Proteção aos Índios na gestão Rondon (1939-1955), 1990. Dissertação de Mestrado Rio de Janeiro: Universidade Federal do Rio de Janeiro.

FREIRE, C. A. R. A criação do Conselho Nacional de Proteção aos Índios e o indigenismo interamericano (1939-1955). Boletim do Museu do Índio, 5: 1-64,1996.

FREIRE, C. A. R. O SPI na Amazônia: política indigenista e conflitos regionais, 1910-1932. Rio de Janeiro: Museu do Índio/Funai, 2007. (Série Publicação Avulsa do Museu do Índio, 2). 
HAMILTON, W. G FONSECA, C. M. O. Política, atores e interesses no processo de mudança institucional: a criação do Ministério da Saúde em 1953. História, Ciências, SaúdeManguinhos, 10 (3): 791-825, 2003.

HOCHMAN, G. A Era do Saneamento: as bases da política de saúde pública no Brasil. São Paulo: Hucitec, Anpocs, 1998.

KROPF, S. P. Doença de Chagas, Doença do Brasil: ciência, saúde e nação (1909-1962). Rio de Janeiro: Editora Fiocruz, 2009.

LANGDON, J. E. G GARNELO, L. (Orgs.). Saúde dos Povos Indígenas: reflexões sobre antropologia participativa. Rio de Janeiro: Contra Capa Livraria, ABA, 2004.

LIMA, N. T. Missões civilizatórias da República e interpretação do Brasil. História, Ciência, Saúde - Manguinhos, 5(supl.): 163-193, 1998.

LIMA, N. T. Um Sertão Chamado Brasil. Rio de Janeiro: Renavan, Iuperj, Ucam, 1999.

LIMA, N. T. Uma brasiliana médica: o Brasil Central na expedição científica de Arthur Neiva e Belisário Penna e na viagem ao Tocantins de Julio Paternostro. História, Ciências, Saúde - Manguinhos, 16(supl. 1): 229-248, 2009.

LIMA, N. T. G MAIO, M. C. Ciências sociais e educação sanitária: a perspectiva da Seção de Pesquisa Social do Serviço Especial de Saúde Pública na década de 1950. História, Ciência, Saúde-Manguinhos, 17(2): 511-526, 2010.

LIMA, N. T. G SÁ, D. M. Roquette-Pinto e sua geração na República das Letras e da Ciência. In: LIMA, N. T. G SÁ, D. M. (Org.). Antropologia Brasiliana: ciência e educação na obra de Edgard Roquette-Pinto. Belo Horizonte, Rio de Janeiro: Editora UFMG, Editora Fiocruz, 2008.

LIMA, N. T.; FONSECA, C. O. G HOCHMAN, G. A saúde na construção do Estado nacional no Brasil: a reforma sanitária em perspectiva histórica. In: LIMA, N. T. et al. (Orgs.). Saúde e Democracia: história e perspectivas do SUS. Rio de Janeiro: Editora Fiocruz, 2005.

LIMA, N. T; SANTOS, R. V. G COIMBRA JR., C. E. A. Introdução à Rondônia de Edgard Roquette-Pinto. In: ROQUETTE-PINTO, E. (Org.). Rondonia: anthropologia - ethnografia. 7. ed. Rio de Janeiro: Editora Fiocruz, Academia Brasileira de Letras, 2005.

LIMONGI, F. Mentores e clientela da Universidade de São Paulo. In: MICELI, S. (Org.). História das Ciências Sociais no Brasil. São Paulo: Revista dos Tribunais, 1989. v. 1.

MAIA, J. M. E. Estado, Território e Imaginação Espacial: o caso da Fundação Brasil Central. Rio de Janeiro: FGV Editora, 2012.

MAIO, M. C. G LIMA, N. T. Tradutores, intérpretes ou promotores de mudança? Cientistas sociais, educação sanitária rural e resistências culturais (1940-1960). Sociedade e Estado, 24(2): 529-561, 2009.

MATTOS, A. L. L. B. Darcy Ribeiro: uma trajetória (1944-1982), 2007. Tese de Doutorado, Campinas: Universidade Estadual de Campinas. 
OLIVEIRA, N. S. Estudos de Comunidade, Ciências Sociais e Saúde: o ciclo de pesquisas no Vale do São Francisco na década de 1950, 2010. Dissertação de Mestrado, Rio de Janeiro: Casa de Oswaldo Cruz, Fundação Oswaldo Cruz.

OLIVEIRA, P. H. Vacinação grátis contra febre amarela e tuberculose. Extração de dentes grátis. Curativo e remédio grátis. Tudo por conta do Governo!!! In: ENCONTRO REGIONAL DE HISTÓRIA: PODER, VIOLÊNCIA E EXCLUSÃO, 19, Anpuh/SP-USP, 2008, São Paulo. Anais... São Paulo, 2008. CD-ROM.

OLIVEIRA, R. C. A Sociologia do Brasil Indígena. Rio de Janeiro, Brasília: Tempo Brasileiro, Editora UnB, 1978.

PAGLIARO, H.; AZEVEDO, M. M. G SANTOS, R. V. (Orgs.). Demografia dos Povos Indígenas no Brasil. Rio de Janeiro: Editora Fiocruz, Abep, 2005.

PAIVA, C. H. A. A saúde pública em tempos de burocratização: o caso do médico Noel Nutels. História, Ciência, Saúde - Manguinhos, 10(3): 827-851, 2003.

PASSADOR, L. H. Herbert Baldus e a Antropologia no Brasil, 2002. Dissertação de Mestrado, Campinas: Instituto de Filosofia e Ciências Humanas, Universidade Estadual de Campinas.

PAZ, M. C. Noel Nutels: a política indigenista e a assistência à saúde no Brasil Central (1943-1973), 1994. Dissertação de Mestrado, Rio de Janeiro: Instituto de Medicina Social, Universidade do Estado do Rio de Janeiro.

PEIRANO, M. G. S. Desterrados e exilados: antropologia no Brasil e na Índia. In: OLIVEIRA, R. C. G RUBEN, G. R. (Orgs.). Estilos de Antropologia. Campinas: Editora da Unicamp, 1995.

QUEIROZ, M. I. P. O Campesinato Brasileiro: ensaios sobre civilização e grupos rústicos no Brasil. Petrópolis: Vozes, 1973.

RAMOS, A. R. Ethnology Brazilian Style. Brasília: Universidade de Brasília, 1990. (Trabalhos em Ciências Sociais, Série Antropologia 89).

RIBEIRO, D. Os Índios e a Civilização. Rio de Janeiro: Civilização Brasileira, 1970.

RIOS, J. A. Entrevista realizada por Nísia Trindade de Lima, Marcos Chor Maio e José Leandro Cardoso. Acervo História Oral. Rio de Janeiro: Casa de Oswaldo Cruz, 2006.

ROQUETTE-PINTO, E. (Org.). Rondonia: anthropologia - ethnografia. 7. ed. Rio de Janeiro: Editora Fiocruz, Academia Brasileira de Letras, 2005.

SÁ, D. M. A voz do Brasil: Miguel Pereira e o discurso sobre o "imenso hospital". História, Ciências, Saúde-Manguinhos, 16(supl.1): 333-348, 2009.

SÁ, D. M.; SÁ, M. R. G LIMA, N. T. Telégrafos e inventário do território no Brasil: as atividades científicas da Comissão Rondon (1907-1915). História, Ciências, Saúde - Manguinhos, 15(supl.): 779-811, 2008.

SANTOS, L. A. C. O pensamento sanitarista na Primeira República: uma ideologia de construção da nacionalidade. Dados - Revista de Ciências Sociais, 28(2): 193-210, 1985. 
SANTOS, R. V. et al. Saúde dos povos indígenas no Brasil. In: GIOVANELLA, L. et al. (Orgs.). Políticas e Sistema de Saúde no Brasil. Rio de Janeiro: Editora Fiocruz, Cebes, 2009.

SCHWEIKARDT, J. C. G LIMA, N. T. Os cientistas brasileiros visitam a Amazônia: as viagens científicas de Oswaldo Cruz e Carlos Chagas (1910-1913). História, Ciências, Saúde Manguinhos, 14(supl.): 15-50, 2007.

SOUZA LIMA, A. C. Um Grande Cerco de Paz: poder tutelar, indianidade e formação do Estado no Brasil. Rio de Janeiro: Vozes, 1995.

SOUZA LIMA, A. C. G BARROSO-HOFFMAN, M. Estado e povos indígenas no Brasil. In: SOUZA LIMA, A. C. G BARROSO-HOFFMAN, M. (Orgs.). Estado e Povos Indígenas: bases para uma política indigenista II. Rio de Janeiro: Contra Capa, 2002.

THIELEN, E. et al. A Ciência a Caminho da Roça: imagens das expedições científicas do Instituto Oswaldo Cruz ao interior do Brasil (1903-1911). Rio de Janeiro: Casa de Oswaldo Cruz, 2002.

VILLAS-BÔAS, G. Mudança Provocada: passado e futuro no pensamento sociológico brasileiro. Rio de Janeiro: Editora FGV, 2006.

VIVEIROS, E. Rondon Conta Sua Vida. Rio de Janeiro: Livraria São José, 1958. 


\section{Campanhas Públicas, Populações (Quase) Invisíveis: endemias rurais e indígenas na saúde pública brasileira}

Gilberto Hochman

Renato da Silva

A saúde pública tem escrutinado o território do Brasil e suas populações desde a instauração do regime republicano, contudo ela tardou décadas para encontrar - em suas ideias, formulações e ações - os povos indígenas. Este capítulo trata desse desencontro e da invisibilidade dos problemas de saúde indígenas para os serviços sanitários voltados para o controle das endemias rurais. O combate às doenças do interior do Brasil, das áreas rurais, dos sertões, da Amazônia, dava-se justamente nos espaços onde essas populações indígenas se localizavam, reforçando tanto sua invisibilidade como sua outra face, as instituições tutelares. O modelo de campanhas contra as endemias rurais que foi sendo elaborado ao longo da primeira metade do século XX tinha como objeto de intervenção as populações rurais, os sertanejos ou homens e mulheres do interior. Estes deveriam ser incluídos na comunidade nacional via educação, saúde e saneamento. Tal modelo, ainda que modificado, perdurou até a década de 1970.

Ainda que indígenas apareçam nos relatos, registros e fotografias dos médicos da saúde pública, os primeiros estavam sob tutela de outras instituições estatais e não pertenciam, nas palavras de Benedict Anderson (2000), à "comunidade imaginada" desses últimos. Foram os projetos de integração nacional e de desenvolvimento do Estado Novo e do pós-Segunda Guerra Mundial que promoveram os primeiros e trágicos encontros entre expansão do poder público, projetos econômicos, saúde pública institucionalizada e populações indígenas.

A partir dos anos 1950 é que se esboçariam os traçados de uma política de saúde para as populações indígenas que se tornavam cada vez mais visíveis na sua fricção com a expansão do Estado e do capitalismo. É dessa década em diante que a saúde pública institucionalizada, em particular os serviços de controle de endemias rurais, começa a dialogar de modo mais sistemático com as instituições de tutela dos indígenas. 


\section{A Construção da Agenda de Controle das Endemias Rurais na Saúde Pública Brasileira}

Desde meados do século XIX, mas em particular nas primeiras décadas republicanas, a agenda sanitária esteve voltada para o saneamento da capital federal e dos principais portos do país, em consonância com uma economia agroexportadora e crescentemente receptora de mão de obra imigrante. A peste bubônicar a cólera e a varíola eram as doenças epidêmicas enfrentadas pelo poder público com os crescentes suportes da bacteriologia e de seus artefatos, tais como a vacina e os soros associados com as tradicionais medidas de higiene, isolamento e quarentena. A febre amarela emergiu como alvo da atenção nacional e internacional nesse mesmo período, tornando-se prioridade nas relações sanitárias internacionais em saúde a partir dos avanços no conhecimento sobre vetores transmissores de doenças designadas de tropicais pela medicina colonial.

O olhar médico-sanitário brasileiro fixava-se nos imigrantes, nos visitantes estrangeiros e na população urbana. Manter aberto o fluxo de mercadorias e de mão de obra era a prioridade da saúde pública, que tornava o porto e as cidades do litoral os lugares privilegiados de suas ações. Na capital federal, atenção particular foi dada também às doenças associadas à pobreza e aos pobres, com seus hábitos e suas habitações - tais como tuberculose, febre tifoide, sífilis. A reforma urbana da cidade do Rio de Janeiro e as campanhas sanitárias lideradas por Oswaldo Cruz como diretor da Saúde Pública (1903-1907), assim como as ações de modernização e saneamento do porto de Santos lideradas por Emílio Ribas e Adolfo Lutz, foram algumas das iniciativas mais conhecidas (Costa, 1985; Benchimol, 1990, 2003; Almeida, 2003; Löwy, 2006; Rebelo, Maio G Hochman, 2011).

Como parte do processo de formação de Estado, os caminhos da saúde pública no Brasil guardam semelhanças com outras experiências nacionais, na América Latina e na Europa. O medo e a ameaça da doença dos males dos outros - pobres, imigrantes, estrangeiros -, que poderia infectar as elites ou o Brasil, promoveram uma complexa rede de interdependência sanitária urbana, real ou imaginária, que instigou elites e governos a darem os primeiros passos mais efetivos na institucionalização da saúde pública no início do século XX. Nessas três primeiras décadas republicanas, povos indígenas - em qualquer definição - estavam fora da agenda da saúde pública brasileira, das ações de suas instituições e das reflexões e preocupações de seus atores. Essa invisibilidade era baseada e reforçada pela omissão da Constituição de 1891 em relação aos indígenas, seus direitos e suas terras, que, associada ao federalismo e à legislação subsequente sobre terras públicas, ficou sob responsabilidade e foi transferida para a esfera dos entes federativos subnacionais (Cunha, 1992). 
A década de 1910 assiste à redescoberta dos sertões pelos médicos brasileiros e a um movimento político pelo saneamento do Brasil cujos objetivos principais eram a centralização das ações sanitárias nas mãos da União e o aumento de sua capacidade de implementar ações no interior do país (Castro-Santos, 1985; Lima G Hochman, 1996; Hochman, 2012; Lima, 1999). Com a descoberta em 1909 de uma nova entidade nosológica no interior de Minas Gerais, a doença de Chagas (tripanossomíase americana), concomitante e seguida de expedições científicas do Instituto Oswaldo Cruz ao interior do país, houve uma mudança de foco nas preocupações das autoridades sanitárias (Kropf, 2009a). O Brasil passou a ser descrito como "um imenso hospital", frase retórica, que se tornou incendiária, do médico Miguel Pereira em outubro de 1916 (Sá, 2009). Essa caracterização foi baseada num diagnóstico dramático construído coletivamente por médicos, jornalistas, bacharéis e políticos que se surpreendiam com os relatos de uma população do interior do país esquecida pelo Estado e devastada por doenças.

Para um apóstolo do saneamento rural como Belisário Penna, os males do Brasil não seriam derivados do clima nem da raça, mas do analfabetismo e das doenças que eram endêmicas, em razão do abandono das populações rurais pelas elites políticas encasteladas no litoral (Penna, 1918) - abandono resultante da prevalência dos interesses locais sobre os nacionais sob a moldura do federalismo da Constituição de 1891 (Hochman, 2012). Uma nova categoria, a de endemias rurais, foi organizadora desse debate médico-político desde sua formulação por Carlos Chagas, em 1910 (Kropf, 2009b). Para o movimento político pelo saneamento do Brasil, a prioridade a partir de então seriam as enfermidades dos sertões, as endemias rurais ou, na definição de Carlos Chagas, as "doenças do Brasil", em particular a "trindade maldita": mal de Chagas, malária e ancilostomíase (Kropf, 2009a). Como consequência, a medicina pública teria como missão resgatar as populações do interior do Brasil.

As décadas de 1910 e 1920 significaram um deslocamento de atenção para a saúde dos homens e mulheres do interior do Brasil, porém suas diversidades geográficas, culturais e étnicas ficaram subsumidas na sua caracterização como sertanejos, caipiras e jecas-tatus. O que se discutia era a possibilidade de seu pertencimento a uma comunidade nacional, baseada na consciência da interdependência social derivada dos efeitos negativos e coletivos das endemias rurais. Esses personagens eram os novos outros, os estrangeiros em sua própria terra sob os olhares da saúde pública com óculos euclidianos. A incorporação desses homens e mulheres doentes e abandonados ao Brasil deveria ser realizada via saúde e educação. Uma incorporação certamente hierarquizante, porém diversa e na direção contrária das propostas eugênicas mais duras ou negativas que emergiram no final da década de 1910 (Lima G Hochman, 1996; Stepan, 2004; Hochman, Lima G Maio, 2010). A criação do Serviço de Profilaxia Rural e do Serviço de Quinina Oficial, em 1918, e 
do Departamento Nacional de Saúde Pública (DNSP), em 1919, foi a materialização desses esforços iniciais de nacionalização e interiorização da saúde pública sob a égide do governo federal (Hochman, 2012).

As viagens científicas ao interior que redescobrem o Brasil, na maioria dos casos acompanhando e apoiando obras de infraestrutura, podem ser compreendidas, conforme sugere Lima (1999), como "missões civilizatórias da República". A Comissão Construtora de Linhas Telegráficas do Mato Grosso ao Amazonas (1909-1915) - a Comissão Rondon - foi uma dessas missões que agregaram médicos, botânicos e antropólogos ao contingente militar comandado por Cândido Rondon (Maciel, 1998; Diacon, 2006). Indígenas, caboclos e sertanejos foram objetos do olhar dos cientistas, incluindo condições de vida e de saúde. Seus relatos e preocupações estavam dentro da mesma moldura das expedições médico-científicas do período: buscavam a integração das populações e territórios ao país e a presença do poder público via infraestrutura e serviços públicos (Sá, Sá G Lima, 2008; Caser G Sá, 2010, 2011). Porém, foram acompanhados de disjunções ideológicas, políticas e institucionais que separaram os povos indígenas das populações rurais, o alvo prioritário da ação da saúde pública. Esta parece ser uma das limitações importantes do que seria a nação imaginada que acompanharia a saúde pública brasileira ao longo do século XX.

Um exemplo foi a criação do Serviço de Proteção aos Índios e Localização de Trabalhadores Nacionais em 1910, depois, em 1918, apenas Serviço de Proteção aos Índios (SPI). Integrante do Ministério da Agricultura, Indústria e Comércio, deveria ser o órgão federal encarregado de executar a política indigenista. Sua principal finalidade era reconhecer e proteger os índios, assegurar a implementação de uma estratégia de ocupação territorial do país e integrá-los à comunidade nacional ou, segundo Souza Lima (1992; 1995), o lugar de onde o Estado exerceria o poder tutelar. A política integracionista continha preocupações com a saúde indígena que ficariam a cargo do SPI, e não da saúde pública institucionalizada, localizada no então Ministério da Justiça e Negócios Interiores. Para o DNSP, braço institucional da saúde pública que se expandia ao longo da década de 1920, a comunidade nacional a ser saneada seria composta pelos trabalhadores rurais, pelas populações do interior do Brasil, e dela estavam institucionalmente excluídos os povos indígenas. A ênfase nas endemias rurais - consagradas como "patologias da pátria", conforme sugerem Hochman, Di Liscia e Palmer (2012) - tornava visíveis e alvos preferenciais da ação do Estado alguns segmentos da população que habitavam o Brasil profundo, e invisíveis outros.

O primeiro governo Vargas (1930-1945) produziu novas distinções nos cuidados com a saúde da população brasileira. A expansão da política de proteção social foi voltada para os trabalhadores urbanos, em particular aqueles membros de categorias profissionais reconhecidas pelo Estado, dentro do modelo corporativo. A criação do Ministério do Trabalho, Indústria e Comércio em 1930 e, em 
anos seguintes, a dos institutos de aposentadoria e pensões conforme a categoria profissional (marítimos, bancários, portuários, industriários, funcionários públicos, trabalhadores dos transportes e cargas) delimitaram quem teria titularidade de direitos sociais tais como assistência médica e previdência social (Malloy, 1986; Hochman, 2005). Esses trabalhadores passaram a ter acesso à proteção pública como membros de uma categoria profissional organizada e reconhecida pelo Estado, uma cidadania regulada (Santos, 1979). Os trabalhadores rurais e a população do interior estavam excluídos dessa política, assim como aqueles trabalhadores urbanos que não pertenciam a essas categorias que ficavam dependentes da assistência pública. Caberia à saúde pública, agora alocada no Ministério da Educação e Saúde (MES), criado em 1930, atender esse amplo, diverso e difuso grupo daqueles não incorporados ao mundo urbano via trabalho formal. Essa disjunção no acesso à proteção médica e previdenciária foi corroborada pelo campo da saúde e assim permaneceu durante sessenta anos (Hochman G Fonseca, 1999; Fonseca, 2007). Nas palavras do então ministro da Educação e Saúde, Gustavo Capanema, "o caso individual só interessa à saúde pública se puder afetar a coletividade, se for capaz de pôr a coletividade em perigo" (apud Hochman G Fonseca, 1999: 141). O desafio político da saúde pública era imenso diante de um aterrador quadro sanitário, tanto no interior como, ainda, nas principais cidades. Além disso, dado o peso dos interesses de proprietários de terras e dos potentados locais, a extensão de direitos sociais aos trabalhadores rurais só seria ensaiada no início dos anos 1960, e efetivada no regime militar.

A ocupação dos chamados grandes vazios demográficos, que efetivamente não eram alcançados pela autoridade pública, nem pela saúde, continuou na agenda e ganhou destaque no governo Vargas como política de integração nacional: a Marcha para o Oeste e o Saneamento da Amazônia. Tais programas ganharam sentidos diversos em um contexto de aumento do envolvimento do Brasil na Segunda Guerra Mundial a partir de 1941. Do ponto de vista legal, as constituições de 1934, 1937 e, depois, a de 1946 garantiam aos indígenas a posse da terra por eles ocupada, ainda que todas silenciassem sobre quaisquer outros direitos. A criação da Fundação Brasil Central (vinculada ao Ministério da Agricultura) e as expedições por ela patrocinadas objetivavam a integração dessas áreas. Em relação às populações indígenas, o maior impacto foi o da Expedição Roncador-Xingu (1943), organizada pela Comissão de Mobilização Econômica (Maia, 2012). O envolvimento do médico tisiologista Noel Nutels nessa expedição - e com a saúde das populações indígenas pavimentou o caminho para a percepção da situação crítica da assistência médica no interior, em áreas sem comunicação por terra, das epidemias nas áreas indígenas e da precariedade dos pontos do SPI, quando existiam. Daí emergiu a demanda de médicos, antropólogos e indigenistas por um serviço aéreo de assistência à saúde no Brasil Central durante o segundo governo Vargas, que levou à criação, em 1956, 
do Serviço de Unidades Sanitárias Aéreas (Susa), vinculado ao Serviço Nacional de Tuberculose, no qual Nutels trabalhava (Costa, 1987; Paiva, 2003; Paz, 1994).

Durante o primeiro Governo Vargas, por um lado, o modelo de ações desenvolvidas na Primeira República foi aprofundado com o foco sobre doenças infectocontagiosas e endêmicas, com ênfase na tuberculose, na lepra e nas endemias rurais, em especial a malária. Por outro, as ações verticais, voltadas para as doenças consideradas prioritárias pelo governo, ganharam inéditas institucionalidade e perenidade. Em 1941, uma reforma do MES criou serviços nacionais para determinadas doenças: de malária, de lepra, de tuberculose, da peste, de doenças mentais e do câncer. O Serviço Nacional de Febre Amarela, criado em 1937, atuava em conjunto com a Divisão Sanitária Internacional da Fundação Rockefeller. Além desses, foram criados o Serviço Nacional de Educação Sanitária, o Serviço Nacional de Fiscalização da Medicina, o Serviço Nacional de Saúde dos Portos, o Serviço Federal de Bioestatística e o Serviço Federal de Águas e Esgotos. Dado o conjunto diverso e relevante de endemias rurais, as ações de controle estiveram associadas a alguns serviços, em particular ao Serviço Nacional de Malária (Hochman G Fonseca, 1999; Hochman, 2008). Apesar de muitas vezes restritas ao mesmo território e população, e subordinadas ao Departamento Nacional de Saúde (DNS), tendiam a não se comunicarem nem se integrarem, produzindo irracionalidades tais como superposições de competências com resultados abaixo das expectativas e muito desiguais entre os vários serviços. Essa característica de baixa integração foi reforçada com a criação em 1942 do Serviço Especial de Saúde Pública (Sesp), como parte da cooperação bilateral dos Estados Unidos durante o esforço de guerra (Campos, 2006). Como agência bilateral e autônoma inicialmente criada para prover serviços de saúde e saneamento nas áreas de produção de matérias-primas estratégicas, o Sesp expandiu consideravelmente suas atividades, mantendo sua autonomia mesmo depois da criação, em 1953, do Ministério da Saúde (Hamilton G Fonseca, 2003).

A principal característica desse modelo, não exclusivo do Brasil, é que as ações deveriam ter um foco preciso: uma enfermidade. Sua racionalidade e eficiência estariam associadas a metas de controle - e possível erradicação - de uma doença baseada no uso intensivo de técnicas e tecnologias oferecidas pela ciência sanitária e numa organização administrativa racional com capacidade de coordenação em nível nacional. Tal modelo enfatizaria, de modo geral, intervenções sanitárias centralizadas, verticais, tecnologicamente orientadas e focadas na resolução de problemas sanitários específicos e separados dos processos de mudança social e ambiental, perspectiva denominada de concepção biomédica restrita da saúde (Packard G Brown, 1997). Outra característica desse modelo é sua desconsideração das práticas e dos conhecimentos da população e sua diversidade, vis-à-vis à superioridade e universalidade do conhecimento biomédico que deveria estruturar as 
ações da saúde pública. Essa perspectiva se tornou hegemônica nas duas décadas seguintes ao final da Segunda Guerra Mundial.

Como sugere John Farley (2004), nesse período, os esforços para melhorar a saúde e o bem-estar econômico das populações podem ser compreendidos como três pêndulos que se moviam entre dois extremos, nem sempre em igual velocidade e de modo coincidente. Primeiro, entre a crença de que o controle ou mesmo a erradicação das doenças transmissíveis é um pré-requisito para o desenvolvimento e a convicção de que, embora o controle seja necessário, o desenvolvimento socioeconômico é pré-requisito para a melhoria da saúde. Segundo, entre a crença de que campanhas contra as doenças deveriam ser dirigidas verticalmente contra cada doença, especificamente, e a crença de que as campanhas contra as doenças deveriam ser dirigidas horizontalmente em relação a um conjunto de doenças e produzir condições básicas de infraestrutura sanitária. Por último, entre os defensores da ideologia do desenvolvimento e uma compreensão de que o sistema internacional reproduz o subdesenvolvimento e um permanente padrão de desigualdades entre países (Farley, 2004: 284-285).

Até o final da década de 1950, a saúde internacional e seus especialistas estavam convencidos de que a erradicação de doenças poderia preceder o desenvolvimento econômico - e ser condição para ele - e de que campanhas verticalmente organizadas com objetivos precisos seriam seus melhores instrumentos. A certeza da vitória possível e rápida sobre as doenças infecciosas, em particular as doenças tropicais, foi proclamada em discurso de 1948 pelo próprio secretário de Estado dos Estados Unidos, George Marshall. Uma série de novos recursos profiláticos e terapêuticos como o diclorodifeniltricloroetano (DDT), a penicilina e os antimaláricos animavam governos e organizações internacionais, estabelecendo o que se convencionou chamar de otimismo sanitário.

Para a chave interpretativa do desenvolvimento como campo discursivo que criou ideias e práticas internacionais, nacionais e locais (Escobar, 1998; Rist, 2002), a ciência e a tecnologia passaram a ser vistas como fundamentais para o acesso dos países pobres ao Primeiro Mundo, evitando-se que esses países se tornassem suscetíveis ao populismo e ao socialismo. Para Arturo Escobar (1998), o mundo teria sido colonizado pelo discurso do desenvolvimento, e a malária seria a doença econômica por excelência (Packard G Brown, 1997). A cooperação técnica das agências internacionais e dos países ditos desenvolvidos se tornaria fundamental para o inevitável empreendimento do desenvolvimento. No ambiente da Guerra Fria, libertar os povos da doença e da ignorância seria impedi-los de cair na órbita do socialismo (Cueto, 2007). As populações que deveriam ser retiradas do subdesenvolvimento eram consideradas indistintamente atrasadas: populações do campo, trabalhadores rurais e indígenas, ainda que no Brasil tais demarcações fossem mais salientes do que, por exemplo, em outros países latino-americanos. 
Essas relações entre saúde e desenvolvimento aparecem em todas as mensagens presidenciais do período nacional-desenvolvimentista. Na sua mensagem de 1949, Dutra reconhecia que "as condições sanitárias de um país circunscrevem-lhe rigidamente o desenvolvimento econômico-social" (Brasil, 1949: 127), perspectiva reafirmada por Vargas em seu segundo período presidencial (1951-54). Mesmo não ocupando lugar de destaque nos planos de desenvolvimento (Pena, 1977), a saúde foi crescentemente associada ao desenvolvimento nacional (Braga G Paula, 1981). Como romper o "ciclo vicioso da doença e da pobreza" (Myrdall, 1952) mediante a compreensão dos "custos da doença e o valor da saúde" (Winslow, 1955) seria a principal questão da agenda sanitária brasileira dos anos 1950 e 1960 (Lima, Fonseca G Hochman, 2005).

\section{Desenvolvimento, Endemias Rurais e os Primeiros Encontros com a Saúde Indígena}

Algumas respostas seriam dadas no programa e nas políticas de saúde na presidência de Juscelino Kubitschek (JK), envoltas pelo otimismo do desenvolvimento ("50 anos em 5") e pelas iniciativas de interiorização do poder público federal, cujo emblema foi a construção da nova capital no Brasil Central (Gomes, 2002; Moreira, 1998). A segunda metade da década de 1950 assistiu a iniciativas importantes em saúde rural que, de algum modo, tiveram impacto na atenção à saúde das populações indígenas. A primeira decisão importante no campo da saúde, logo após a posse de JK, foi a criação do Departamento Nacional de Endemias Rurais (DNERu), pela lei n. 2.743/1956, sendo subordinado diretamente ao Ministério da Saúde que unificava vários serviços nacionais criados em 1941 para lidar com as doenças do interior, tais como malária, leishmaniose, doença de Chagas, peste, brucelose, febre amarela, esquistossomose, ancilostomose, filariose, hidatidose, bouba, tracoma e bócio endêmico, esta última uma doença carencial, não transmissível. A tuberculose e a lepra continuaram sendo objeto de serviços nacionais específicos e, ainda que afetassem também as populações do interior, não eram categorizadas como endemias rurais. Vários centros de pesquisa do Ministério da Saúde, inclusive o Instituto de Malariologia, foram unificados no Instituto Nacional de Endemias Rurais (INERu), que passou a ser subordinado ao DNERu. Este tornou-se a principal estrutura de saúde no governo JK (janeiro de 1956-janeiro de 1961) (Silva, 2008; Hochman, 2009b). O DNERu renovava a agenda do saneamento rural que emergiu na década de 1910 e se institucionalizou no primeiro Governo Vargas (1930-45). Todavia, aprofundava e acelerava sua burocratização e rotinização, assim como reforçava a dualidade entre saúde pública e assistência médica previdenciária. 
O programa de saúde apresentado por JK na campanha eleitoral de 1955 é ilustrativo das prioridades do setor e de seu enquadramento pela ideia de desenvolvimento (Kubitschek, 1955). O principal diagnóstico expresso nesse documento de quase sessenta páginas é que os problemas de saúde da população brasileira, em particular as endemias rurais, a incapacitavam para o empreendimento urgente e necessário do desenvolvimento nacional. A associação entre saúde e desenvolvimento que emerge desse programa não seria redutível à simples opção por priorizar um dos termos deste binômio: foco na melhoria das condições de saúde da população versus saúde como resultado do desenvolvimento do país. Ecoava em suas propostas a necessidade de se romper o círculo vicioso da doença e da pobreza; e estão presentes no discurso de candidato de JK intenções que, mesmo ao enfatizarem a dimensão do combate às doenças como crucial, não deixavam de reconhecer a necessidade de mudança nas condições de vida da população. Todavia, em seu programa de governo não há uma única menção às populações indígenas.

Esse programa era apresentado com uma legitimidade intrínseca e inequívoca, porque JK se apresentava não apenas como político, mas como médico conhecedor das "dores de nosso povo" e, sobretudo, do que se passava no interior do Brasil. Imagem reforçada pelo seu mandato como governador de Minas Gerais entre 1951 e 1955 (Kubitschek, 1955: 3). É dessas posições - de médico, de político oriundo do interior e de governador de um estado que abrigava parte significativa dos problemas sanitários e sociais do Brasil - que JK fez seu diagnóstico e propôs 18 metas para superação do que considerava os principais problemas sanitários do Brasil, em grande parte voltada para o controle e a erradicação das endemias rurais.

O programa de JK para as doenças do interior reforçava a continuidade de aspectos do dualismo litoral/sertão, presente no pensamento social e político brasileiro e marcante no discurso médico-higienista da década de 1910 e 1920 (Lima, 1999; Hochman, 2009b). Desconhecimento, preconceito e abandono dos sertões pelos governos, pelos homens do litoral, continuavam sendo apresentados como elementos das explicações sobre os males sanitários do país. Em algumas passagens do programa, JK denuncia que o desconhecimento, por parte do Brasil urbano, dos homens e mulheres do interior se expressaria de duas maneiras diversas, porém preconceituosas. De um lado, pela visão negativa que caracterizaria essa população como indolente, e de outro, pela admiração à resistência e ao heroísmo atribuídos aos habitantes do interior (Kubitschek, 1955). Em ambos os casos, as concepções distorcidas produziram um desamparo histórico dessas populações pelos governantes e o seu esquecimento pelas classes médias urbanas. A separação desses brasis e a visão negativa aparecem na imagem "poltronas e chão duro", pela qual JK criticava aqueles que, em seu conforto material, não compreendiam as agruras das famílias camponesas. O personagem acionado é o turista que, de uma confortável gaiola, avista os barranqueiros do São Francisco e os define 
como preguiçosos (Kubitschek, 1955). Opondo-se ao que considerava uma visão positiva, porém desvirtuada, o programa de saúde aciona diretamente Euclides da Cunha e seu personagem, o vaqueiro. Para JK, a frase "o sertanejo é antes de tudo um forte" fora distorcida pelo Brasil urbano. A afirmação de Euclides não seria um elogio e sim um "protesto contra a indiferença em que o Brasil mal civilizado deixa o Brasil puro e verdadeiro" (Kubitschek, 1955: 20). Sua proposta era rever essa inoperante e lírica glorificação do sofrimento dos sertanejos por meio da extensão da legislação trabalhista à população rural e da ampliação do alcance das políticas de saúde e de assistência.

Derrotadas a peste e a febre amarela (doenças pestilenciais) e aprendidas as lições da malária, que teria retrocedido drasticamente desde a década de 1940 (Kubitschek, 1955), as principais ações de saúde deveriam ser voltadas para a eliminação das demais endemias rurais e para a luta contra a tuberculose e a lepra. Essa possibilidade era considerada viável em meados da década de 1950 justamente pelo pujante desenvolvimento da indústria química e farmacêutica depois da Segunda Guerra Mundial, com destaque para os inseticidas de ação residual, antimaláricos e antibióticos. Para o candidato, "a ciência e a técnica modernas deram aos homens, sobretudo aos governos, novos e eficazes, poderosos e, algumas vezes, imediatos recursos profiláticos e terapêuticos, facilmente aplicáveis, para o combate às doenças de massas" (Kubitschek, 1955: 5). Chama a atenção para o fato de já existirem os instrumentos para eliminar do Brasil a bouba (penicilina injetável), o tracoma (sulfa), o bócio endêmico (iodetação do sal de cozinha), entre outras endemias presentes no interior do Brasil e associadas à pobreza. Esses instrumentos simplificariam as campanhas sanitárias e mudariam o próprio papel do médico da saúde pública, que passaria "a exercer a missão de traçar diretrizes, de fiscalizar e orientar" (Kubitschek, 1955: 5). Bastariam equipes especializadas e bem treinadas para alcançar o objetivo de eliminar as endemias rurais, dada a simplificação das ações terapêuticas. Como assinalou no caso da bouba e também do tracoma: "Basta aplicar uma injeção..." para libertar milhares de brasileiros que poderiam "trabalhar pelo Brasil tão necessitado de trabalho" (Kubitschek, 1955: 25). Apesar de reconhecer em seu programa a complexidade das relações entre saúde e desenvolvimento, prevalece a chamada concepção estrita dessas relações, associada ao modelo vertical de campanhas; aparece explicitada na crença de que estavam disponíveis balas mágicas que acertariam um alvo preciso, o patógeno, sem afetar ou precisar modificar o restante do organismo doente e seu ambiente, ou seja, as condições de vida que o produziam (Muniz, 2013).

A doença de Chagas é emblemática dessa perspectiva mais estrita. Juscelino reconheceu-a como diretamente vinculada à precariedade das habitações do interior do país (as cafuas), em que se abriga o inseto transmissor (o barbeiro). Considerava, porém, a melhoria habitacional tarefa de longo prazo, afinal "não é 
possível dar imediatamente aos milhões de trabalhadores rurais moradias iguais às da cidade, com a segurança, o conforto e a higiene que eles merecem" (Kubitschek, 1955: 18). Desse modo, o combate ao barbeiro com inseticidas (como o BHC), que vinha sendo realizado desde 1950, seria o recurso imediato, eficaz e disponível para o controle da doença. A eliminação dessa e de outras endemias possibilitaria que população e territórios pudessem ser incorporados ao processo de desenvolvimento capitalista.

Com o otimismo e a retórica de um candidato, JK finalizava seu programa para a saúde dialogando diretamente com Miguel Pereira ao afirmar que "O Brasil não é só doença" e não seria mais um "vasto hospital" (Hochman, 2009b). Para ele o país poderia solucionar os problemas sanitários apropriando-se das "novas armas" da medicina, e listava as doenças-alvo e metas para seu quinquênio - "fáceis de serem alcançadas em cinco anos de trabalhos intensivos" (Kubitschek, 1955: 53) -, em grande parte relativas a doenças específicas associadas ao mundo rural e/ou à pobreza. O programa não seria uma proposta inovadora para a agenda de saúde pública, e sim o aprofundamento de um modelo vigente. Os compromissos que assumia indicavam o desejo de interiorização da saúde pública federal, pois previa que a cada ação sanitária, nos centros urbanos, "uma pequenina Unidade MédicoSanitária" servisse ao "núcleo da população perdido no mais longínquo sertão brasileiro" (Kubitschek, 1955: 57). Reforçava assim, como em todo o seu programa, a ideia de que "o Brasil não se enquadraria, apenas, na sua metrópole e nas capitais dos Estados", mas também "palpitaria" no vaqueiro e no seringueiro, no interior do Brasil (Kubitschek, 1955: 19-20, 25-28). As resistências dos potentados rurais à presença do poder público, os compromissos de JK com o setor agrário, inclusive de seu próprio partido (PSD), a mobilização crescente dos trabalhadores rurais e as prioridades assumidas nos projetos de desenvolvimento tornaram parte desse programa inviável ao longo do seu mandato presidencial (Hippolito, 1985).

O Programa de Saúde Pública do candidato era um mapeamento geral da situação sanitária do Brasil. Apresentava os problemas e as soluções que, em alguns casos, segundo JK, seriam simples de resolver. Esse documento tinha a assinatura implícita de Mario Pinotti, futuro diretor do DNERu (1956) e, depois, ministro da Saúde (1958), mas era um documento mais político do que técnico. A ação do DNERu nos seus 15 anos de existência foi em grande parte pautada pelas perspectivas expressas nesse documento, em particular pelo ânimo do desenvolvimento. O controle das endemias rurais, ainda que unificado e rotinizado em um departamento, foi organizado por meio de campanhas específicas que reforçavam o modelo vertical e não integrado de cuidados com a saúde da população rural, além das ações de engenharia sanitária e de educação sanitária.

Diferentes endemias rurais que se manifestavam numa mesma área ou região estiveram sob a responsabilidade de diferentes campanhas, coordenações e 
equipes de profissionais. No governo JK, foram reorganizadas ou estabelecidas 14 campanhas dentro do DNERu contra as principais endemias rurais: ancilostomose, bócio endêmico, bouba, brucelose, doença de Chagas, febre amarela, hidatidose, filariose, leishmaniose, tracoma, peste e malária. Esta última foi transformada em Campanha de Erradicação da Malária (CEM) em 1958, no contexto de pressões para a integração do Brasil ao esforço da Organização Mundial da Saúde (OMS) em erradicar a malária em escala global e contou com apoio financeiro da cooperação bilateral estadunidense, a United States Agency for International Development (Usaid) (Hochman, 2008; Silva, 2008). A Campanha de Erradicação da Malária adquiriu crescente autonomia e protagonismo, saiu da jurisdição do DNERu em 1965, até ser integrada à Superintendência de Campanhas de Saúde Pública (Sucam) no início dos anos 1970.

A década de 1950 marca um primeiro encontro mais institucionalizado entre a saúde pública brasileira e as populações indígenas. Esse encontro foi produzido por caminhos e questões diferentes, porém interligados. O novo impulso dado à interiorização das ações sanitárias liderada pelo DNERu teria que enfrentar o desafio da presença das populações indígenas e de seus graves problemas sanitários, em particular na Região Centro-Oeste ou no chamado Brasil Central. Se os indígenas não faziam parte da população que seria o alvo prioritário da saúde pública em sua retórica oficial, a sua presença em porções do território nacional potencialmente transformáveis em áreas de interesse econômico para os projetos de desenvolvimento adquiriu crescente visibilidade, inclusive as condições de vida e de saúde.

Dois episódios marcantes para diminuir a invisibilidade, ao menos sanitária, dos indígenas foram a construção e a inauguração de Brasília e também a abertura da rodovia Belém-Brasília. O deslocamento do poder político do litoral para o interior, materializado pela nova capital, gerou uma imensa migração interna na direção do Planalto Central, aumentando a atenção para as condições sanitárias da região, assim como para sua população (Moreira, 1998; Vieira, 2009). A construção da ligação rodoviária entre Brasília e Belém implicou dramático contato com populações indígenas que viviam na região de seu traçado e surtos de malária que paralisavam as frentes de trabalho. A conquista da selva se fez às custas da dizimação de indígenas por enfermidades no contato com as frentes de trabalho (Andrade, 2012). Cabe ressaltar que o declínio demográfico dos povos indígenas não se iniciara no período desenvolvimentista e já vinha sendo estudado nos anos 1940 e 1950 por autores como Charles Wagley e Darcy Ribeiro. Este último analisara o impacto provocado pelas epidemias de doenças infecciosas e parasitárias sobre a demografia e a organização social dos povos indígenas, em particular os efeitos de população (Pagliaro, Azevedo G Santos, 2005).

O DNERu foi o braço sanitário dessa penetração e ocupação territorial, dados os recursos organizacionais, humanos e financeiros de que dispunha e a 
liderança de seu primeiro diretor, o malariologista Mário Pinotti (Hochman, 2008). A capacidade e a efetividade de uma assistência médica fornecida pelo Serviço de Proteção aos Índios (SPI) por meio de seus postos vinham sendo duramente criticada, na medida em que eram reveladas e denunciadas as trágicas condições de saúde dos indígenas sob sua responsabilidade (Paz, 1994; Costa, 1987; Santos et al., 2008). Decorrem desse contexto iniciativas como o convênio SPI-DNERu e o Susa.

Foi o médico João Leão da Motta, chefe da circunscrição do DNERu na região da futura capital do Brasil, que apresentou, em 10 de maio de 1957, uma proposta de convênio entre o SPI e o DNERu. ${ }^{1}$ Nele ficava estabelecido que a assistência médica da população indígena sob a tutela do SPI seria prestada pelo DNERu. Os princípios básicos que orientariam a atenção à saúde dos indígenas pelo departamento seriam: ações de controle e assistência às endemias para as quais o DNERu já possuía postos instalados; a assistência e o combate à lepra, às doenças venéreas e à tuberculose, que não eram caracterizadas como endemias rurais e estavam sob responsabilidade de outros serviços nacionais; assistência clínica não especializada, assistência hospitalar e domiciliar; assistência médica-sanitária em caso de epidemias; vacinação e distribuição de medicamentos. Além disso, o departamento seria responsável pela internação dos índios em hospitais públicos, e o SPI arcaria com as despesas nos casos de a internação ocorrer em hospitais privados e/ou necessitar de transporte e forneceria medicamentos e vacinas para a criação de uma farmácia.

Pelo convênio, as equipes do DNERu deveriam atuar em conjunto com os funcionários do SPI, que seria o principal financiador do convênio. ${ }^{2}$ A construção da Belém-Brasília entre 1958 e 1959 foi acompanhada pelas ações do DNERu, em particular no controle e tratamento da malária, que atingiam trabalhadores e indígenas na região. A penetração na selva das duas frentes de trabalho (via Goiás e Pará) teve enormes implicações do ponto de vista sanitário, uma vez que se tratava de região de malária endêmica (Andrade, 2012).

A combinação entre incapacidade do SPI em lidar com as condições de saúde da população indígena sob tutela e o novo impulso de ocupação do interior do país, que implicava contato com essa mesma população nas frentes de expansão, promoveu algumas modificações no modelo de funcionamento do DNERu e de outros serviços sanitários como o próprio Sesp. As estruturas mais organizadas da saúde pública e com maior presença territorial acabaram por ampliar seu foco de ação para áreas e população formalmente não cobertas pelos seus estatutos legais. ${ }^{3}$ Ainda que o modelo vertical e segmentado por endemias específicas organizasse o DNERu, os desafios dos projetos de desenvolvimento e integração nacional fizeram com que fossem necessárias ações mais concertadas entre as campanhas e fosse ampliada, ou reconfigurada, a população-alvo. Se acordos e convênios foram estabelecidos dentro desse marco histórico (política indigenista e nacional-desenvolvimentismo), as práticas assistenciais nos postos e serviços do 
DNERu, em especial nas circunscrições das Regiões Centro-Oeste e Norte, eram, por vezes, mais integradas do que os organogramas e manuais revelavam. A bibliografia internacional tem indicado que os programas verticais são profundamente reelaborados no campo, em particular pelos profissionais envolvidos no contato direto com a população (Bhattacharya, 2008).

Nos relatos e relatórios, é patente uma tendência esboçada já nos primeiros postos de profilaxia rural da década de 1920 (Hochman, 2012). Em localidades com populações desassistidas, a passagem ou presença de quaisquer serviços médicossanitários, mesmo especializados, gerava demandas por cuidados que originalmente não seriam de sua responsabilidade. Do mesmo modo, serviços contra endemias não poderiam ignorar problemas de saúde dos grupos indígenas que habitavam suas áreas de atuação. Porém, essa ação mais integrada, quando ocorria, era fundada em dois pressupostos que organizavam as campanhas: atribuição de ignorância e atraso das populações (fossem trabalhadores rurais ou indígenas) e a certeza de que ações profiláticas e terapêuticas baseadas no conhecimento biomédico eram suficientes para o controle das doenças infectoparasitárias nessas áreas. Apesar dos programas de educação sanitária e das pesquisas sociológicas realizadas por muitas das campanhas contra as endemias, prevaleceu até a década de 1970 uma concepção biomédica limitada (Packard G Brown, 1997).

O outro encontro entre a saúde pública e as populações indígenas foi o Susa, criado em 1956 para prover serviços de saúde aos índios e populações residentes em locais de difícil acesso. Vinculado administrativamente ao Serviço Nacional de Tuberculose, mas não restrito a essa doença, o Susa foi idealizado e dirigido por Noel Nutels até 1973. Contou com o apoio da Força Aérea Brasileira (FAB), por intermédio do Correio Aéreo Sanitário, criado dentro da FAB, e estava ligado ao Correio Aéreo Nacional, que auxiliava no transporte de material e das equipes de saúde. Inicialmente voltados para a região do Araguaia e Alto Xingu, os trabalhos do Susa se expandiram para as regiões do Rio Negro e do Mato Grosso. Além do tratamento da tuberculose, que cada vez mais acometia os grupos indígenas dessas áreas, nas suas ações concretas as equipes acabaram por executar múltiplas atividades, como vacinação, serviços odontológicos, tratamento de verminoses etc. (Costa, 1987; Paiva, 2003; Paz, 1994). Até a sua transformação em Unidade de Atendimento Especial (UAE) dentro do Ministério da Saúde, em 1968, o Susa teve um papel importante tanto ao estender os cuidados de saúde às populações indígenas como ao influenciar e se associar com outras áreas do Ministério da Saúde e com o próprio SPI, depois com a Fundação Nacional do Índio (Funai), criada em 1967, e suas equipes volantes de saúde.

A maior visibilidade da saúde indígena e as respostas da saúde pública vieram por caminhos diferentes. De um lado, a longa militância de Nutels para proteger e prover assistência médica aos grupos indígenas e, de outro, a estrutura 
do DNERu e seus recursos humanos e técnicos para implementar campanhas sanitárias. Em ambos os casos, a inépcia do SPI e os avassaladores projetos de interiorização e desenvolvimento ameaçavam a saúde e a sobrevivência das populações indígenas, e mesmo das populações do interior. Foram respostas com diferentes graus de institucionalização aos problemas do desenvolvimento econômico. Com o DNERu, numa chave mais positiva, a possibilidade de transformar vítimas das endemias em trabalhadores rurais para um Brasil moderno, incluídos os próprios indígenas; com o Susa, numa chave talvez mais cética, a necessidade urgente de proteger a saúde das vítimas da expansão capitalista e da modernização do país. O maior peso institucional do DNERu vis-à-vis ao Susa, mais dependente do ativismo de Nutels e associados (Paiva, 2003), explica de certa forma a perenidade de seu modelo, mesmo depois da sua incorporação à Sucam em 1970.

Em dezembro de 1960, um mês antes do fim do governo JK, o DNERu reuniu no Rio de Janeiro 15 grupos para avaliar os cinco anos de trabalhos das campanhas contra as endemias rurais (Brasil, 1962). Segundo a avaliação desses grupos, os resultados eram muito diversos. Avanços eram reconhecidos no controle da bouba, da ancilostomose, da peste e da febre amarela; passos iniciais para o combate ao bócio endêmico tinham sido dados com a obrigatoriedade da iodetação do sal de cozinha. A Campanha de Erradicação da Malária ganhara autonomia e recursos da cooperação internacional estadunidense e se tornava o programa mais importante da saúde pública brasileira. A década de 1960 foi, no campo da saúde pública, a da erradicação da malária. O outro programa importante desse período foi a Campanha de Erradicação da Varíola - CEV - (1966-1973), também associada ao Programa de Erradicação da Varíola da OMS. No caso da malária, a estratégia foi revista apenas na Assembleia Mundial da Saúde em 1969 (Cueto, 2007; Packard, 2008); no da varíola, o programa foi muito bem-sucedido, e o Brasil certificado como livre da varíola - a varíola foi considerada erradicada no Brasil em 1973 e no mundo em 1980 (Hochman, 2009a).

Problemas financeiros que afetavam o país desde 1958 eram considerados obstáculos para o bom desempenho das campanhas. Em particular, a extensão do saneamento básico surge como uma condição para o sucesso no controle das verminoses e parasitoses. Porém, se o então diretor do DNERu, Amílcar Vianna Martins, reconhecia os íntimos elos entre desenvolvimento e saúde, reforçava a perspectiva mais limitada dessas relações:

As condições de subdesenvolvimento não podendo ser removidas, como é óbvio, a curto prazo, por infraestrutura econômica que possibilite ao rurícola preservar a saúde, com melhores padrões de alimentação e higiene da habitação, cabe, então, ao Estado promover medidas preventivas para a defesa e proteção da saúde das coletividades atingidas ou ameaçadas pelas endemias. (Brasil, 1962: 8) 
Apesar dos convênios com o SPI e as ações concertadas com o Susa, a questão da saúde indígena foi totalmente ignorada por esse e outros balanços de atividades das campanhas de saúde do governo JK.

A criação da Sucam em 1970, resultou da fusão do DNERu, da Campanha de Erradicação da Malária e da Campanha de Erradicação da Varíola. A Sucam seria, em grande medida, uma combinação do modelo do DNERu com o sucesso da campanha da varíola e o retorno a políticas de controle da malária. Por meio do Programa Nacional do Desenvolvimento (PND), o governo militar esteve à frente de programas ambiciosos, como o Programa de Integração Nacional, que tinha por finalidade ocupar as fronteiras da Amazônia que, naquele tempo, eram consideradas literalmente desabitadas. Grandes estradas, como a rodovia federal BR-364 e a Transamazônica, foram construídas, criando acesso mais amplo ao Norte do Brasil e à fronteira com a Bolívia. A abertura dessas estradas foi acompanhada por um programa de colonização rural, com a implantação de numerosos projetos de assentamento agrícola em toda a Amazônia, a construção de centrais hidrelétricas e o desenvolvimento de projetos de exploração (Moraes, 1990). A Sucam continuaria a reproduzir o modelo das campanhas que absorvera, apenas agora reunidas em um órgão nacional e mais articuladas no caso da Amazônia. Porém, no caso das populações indígenas, o seu grande desafio foram os efeitos perversos da construção da Transamazônica e dos projetos de colonização sobre as populações indígenas da Região, associados à inoperância da Funai em assuntos sanitários. Os anos de construção da Transamazônica e dos projetos de desenvolvimento do regime militar aumentaram a visibilidade dos indígenas, como obstáculos, e por suas tragédias, como os inúmeros surtos de malária e sarampo entre diversos grupos. Esse panorama começaria a mudar nos anos 1980, já num contexto de crítica aos modelos verticais de atenção à saúde, de crise dos projetos de desenvolvimento do regime militar, da instabilidade da Funai e de redemocratização do país.

\section{Conclusões}

Da invisibilidade absoluta nas décadas iniciais da república à visibilidade pela tragédia e pelo contato que se intensificou a partir dos anos 1940, foi longo o caminho percorrido na relação entre saúde pública, endemias rurais e populações indígenas. Dos Serviços de Profilaxia Rural ao DNERu, o modelo instituído foi de campanhas contra endemias rurais específicas com o objetivo de incluir as populações do interior ao mundo civilizado e, depois, nos anos 1950, ao desenvolvimento nacional. As categorias sertanejo, caipira, trabalhador rural, população do interior, objetos dessa agenda, não incluíam povos indígenas, ainda que estes muitas vezes

estivessem compartilhando espaços e mesmo essas identidades patologizadas. Essa patologização que, de um lado, encarcerava populações em preconceitos e subor- 
dinação; de outro, as tornava objeto da ação positiva do Estado. Foi, portanto, uma invisibilidade política, produzida pelo status tutelar ao qual estavam subordinadas as populações indígenas. É a partir da agenda nacional-desenvolvimentista que a saúde indígena fez contato mais íntimo com a saúde pública brasileira. A doença como obstáculo ao desenvolvimento/civilização, e não a saúde como direito, foi a perspectiva que vigorou durante quase um século de experiência republicana. Uma resposta diferente da saúde pública seria dada pela revisão dos modelos verticais e biomédicos a partir do movimento pela atenção primária no fim dos anos 1970, pela Reforma Sanitária brasileira e pela redemocratização do país, que possibilitou uma maior visibilidade da questão da saúde indígena. A Constituição de 1988, o Sistema Único de Saúde (SUS) e o Subsistema de Atenção à Saúde Indígena são resultados, incompletos, dessas mudanças.

Notas

1 Proposta de Convênio, 1957. Serviço de Proteção aos Índios, filme 381, fotograma 468. Acervo do Museu do Índio, Rio de Janeiro.

2 Proposta de Convênio, 1957. Serviço de Proteção aos Índios, filme 381, fotogramas 469-473. Acervo do Museu do Índio, Rio de Janeiro.

3 Para a questão da saúde indígena nas ações do Sesp na Amazônia, ver Sousa e Schweickardt (2013).

\section{Referências}

ALMEIDA, M. República dos Invisíveis: Emílio Ribas, microbiologia e saúde pública em São Paulo (1898-1917). Bragança Paulista: Edusf, 2003.

ANDERSON, B. Comunidades Imaginadas: reflexiones sobre el origen y la difusión del nacionalismo. Buenos Aires: Fondo de Cultura Económica, 2000.

ANDRADE, R. P. A Amazônia na Era do Desenvolvimento: saúde, alimentação e meio ambiente (1946-1966), 2012. Tese de Doutorado, Rio de Janeiro: Programa de Pós-Graduação em História das Ciências e da Saúde, Casa de Oswaldo Cruz, Fundação Oswaldo Cruz.

BHATTACHARYA, S. Contribuições multifacetadas: trabalhadores da saúde e a erradicação da varíola na Índia. Ciência G Saúde Coletiva, 13(3): 955-964, 2008.

BENCHIMOL, J. L. Pereira Passos, um Haussmann tropical: a renovação urbana do Rio de Janeiro no início do século XX. Rio de Janeiro: Secretaria Municipal de Cultura, Turismo e Esportes, Biblioteca Carioca, 1990. 
BENCHIMOL, J. L. Reforma urbana e revolta da vacina na cidade do Rio de Janeiro. In: FERREIRA, J. G NEVES, L. A. (Orgs.). Brasil Republicano: o tempo do liberalismo excludente - da Proclamação da República à Revolução de 1930. v. 1. Rio de Janeiro: Civilização Brasileira, 2003.

BRAGA, J. C. S. G PAULA, S. G. Saúde e Previdência: estudos de política social. Rio de Janeiro, São Paulo: Cebes, Hucitec, 1981.

BRASIL. Congresso Nacional. Mensagem apresentada por ocasião da abertura da sessão legislativa por Eurico Gaspar Dutra. Rio de Janeiro: Imprensa Nacional, 1949.

BRASIL. Departamento Nacional de Endemias Rurais (DNERu). Combate a Endemias Rurais no Brasil: relatórios dos grupos de trabalho reunidos em 1960 na cidade do Rio de Janeiro. Brasília: Ministério da Saúde, 1962.

CAMPOS, A. L. V. Políticas Internacionais de Saúde na Era Vargas: o Serviço Especial de Saúde Pública, 1942-1960. Rio de Janeiro: Editora Fiocruz, 2006. (Coleção História e Saúde).

CASER, A. T. G SÁ, D. M. Médicos, doenças e ocupação do território na Comissão de Linhas Telegráficas e Estratégicas de Mato Grosso ao Amazonas (1907-1915). Boletim do Museu Paraense Emílio Goeldi - Ciências Humanas, 5(2): 363-377, 2010.

CASER, A. T. G SÁ, D. M. O medo do sertão: a malária e a Comissão Rondon (1907-1915). História, Ciências, Saúde-Manguinhos, 18(2): 471-498, 2011.

CASTRO-SANTOS, L. A. O pensamento sanitarista na Primeira República: uma ideologia de construção da nacionalidade. Dados - Revista de Ciências Sociais, 28(2): 237-250, 1985.

COSTA, D. C. Política indigenista e assistência à saúde: Noel Nutels e o Serviço de Unidades Sanitárias Aéreas. Cadernos de Saúde Pública, 4(3): 388-340, 1987.

COSTA, N. R. Lutas Urbanas e Controle Sanitário: origens das políticas de saúde no Brasil. Petrópolis: Vozes, 1985.

CUETO, M. Cold war, deadly fevers: malaria eradication in Mexico, 1955-1975. Washington, D. C.: Woodrow Wilson Center Press, 2007.

CUNHA, M. C. (Org.). História dos Índios no Brasil. São Paulo: Companhia das Letras, 1992.

DIACON, T. Rondon: o marechal das florestas. São Paulo: Companhia das Letras, 2006.

ESCOBAR, A. La Invención del Tercer Mundo: construcción y deconstrucción del desarrollo. Bogotá: Editorial Norma, 1998.

FARLEY, J. To Cast Out Disease: a history of the International Health Division of the Rockefeller Foundation (1913-1951). New York: Oxford University Press, 2004.

FONSECA, C. M. Saúde no Governo Vargas (1930-45): dualidade institucional de um bem público. Rio de Janeiro: Editora Fiocruz, 2007.

GOMES, A. M. C. O Brasil de JK. Rio de Janeiro: Editora da FGV/CPDOC, 2002.

HAMILTON, W. G FONSECA, C. M. O. Política, atores e interesses no processo de mudança institucional: a criação do Ministério da Saúde em 1953. História, Ciências, Saúde Manguinhos, 10(3): 791-825, 2003. 
HIPPOLITO, L. De Raposas e Reformistas: o PSD e a experiência democrática brasileira (1945-64). Rio de Janeiro: Paz e Terra, 1985.

HOCHMAN, G. Cambio político y reformas de la salud pública en Brasil: el primer gobierno Vargas, 1930-1945. Dynamis, 25: 199-226, 2005.

HOCHMAN, G. From autonomy to partial alignment: national malaria programs in the time of global eradication, Brazil, 1941-61. Canadian Bulletin of Medical History, 25(1): 201$232,2008$.

HOCHMAN, G. Priority, invisibility and eradication: the history of smallpox and the Brazilian Public Health agenda. Medical History, 53(2): 229-252, 2009a.

HOCHMAN, G. O Brasil não é só doença: o programa de saúde pública de Juscelino Kubitschek. História, Ciências, Saúde - Manguinhos, 16(sup.1): 313-331, 2009b.

HOCHMAN, G. A Era do Saneamento: as bases da política de saúde pública no Brasil. 3. ed. São Paulo: Hucitec, Anpocs, 2012.

HOCHMAN, G. G FONSECA, C. M. O. O que há de novo? Políticas de saúde pública e previdência, 1937-45. In: PANDOLFI, D. (Org.). Repensando o Estado Novo. Rio de Janeiro: Editora FGV, 1999.

HOCHMAN, G.; DI LISCIA, M. S. G PALMER, S. (Eds.). Patologías de la Patria: enfermedades, enfermos y nación en América Latina. Buenos Aires: Lugar Editorial, 2012.

HOCHMAN, G.; LIMA, N. T. G MAIO, M. C. The path of eugenics in Brazil: dilemmas of miscegenation. In: BASHFORD, A. G LEVINE, P (Eds.). The Oxford Handbook of the History of Eugenics. Nova York, London: Oxford University Press, 2010.

KROPF, S. P. Doença de Chagas, Doença do Brasil: ciência, saúde e nação (1909-1962). Rio de Janeiro: Editora Fiocruz, 2009a.

KROPF, S. P. Carlos Chagas e os debates e controvérsias sobre a doença do Brasil (19091923). História, Ciências, Saúde - Manguinhos, 16(supl.1): 205-227, 2009b.

KUBITSCHEK, J. Programa de Saúde Pública do Candidato. São Paulo: L. Nicollini, 1955.

LIMA, N. T. Um Sertão Chamado Brasil: intelectuais e interpretações geográficas da identidade nacional. Rio de Janeiro: Revan, 1999.

LIMA, N. T. G HOCHMAN, G. Condenado pela raça, absolvido pela medicina: o Brasil descoberto pelo movimento sanitarista da Primeira República. In: MAIO, M. C. G SANTOS, R. V. (Orgs.). Raça, Ciência e Sociedade. Rio de Janeiro: Editora Fiocruz, 1996.

LIMA, N. T.; FONSECA, C. O. G HOCHMAN, G. A saúde na construção do Estado Nacional no Brasil: a reforma sanitária em perspectiva histórica. In: LIMA, N. T. et al. (Orgs.). Saúde e Democracia: história e perspectivas do SUS. Rio de Janeiro: Editora Fiocruz, 2005.

LÖWY, I. Vírus, Mosquitos e Modernidade: a febre amarela no Brasil entre ciência e política, história e saúde. Rio de Janeiro: Editora Fiocruz, 2006.

MACIEL, L. A. A Nação por um Fio: caminhos, práticas e imagens da Comissão Rondon. São Paulo: Edusc, 1998. 
MAIA, J. E. Estado, Território e Imaginação Espacial: o caso da Fundação Brasil Central. Rio de Janeiro: Editora FGV, 2012.

MALlOY, J. A Política da Previdência Social no Brasil. Rio de Janeiro: Graal, 1986.

MORAES, H. F. Sucam: sua origem, sua história. Brasília: Ministério da Saúde, 1990.

MOREIRA, V. M. L. Brasília: a construção da nacionalidade - um meio para muitos fins, 1956-1961. Vitória: Edufes, 1998.

MUNIZ, E. S. Basta Aplicar uma Injeção? Desafios e contradições da saúde pública nos tempos de JK (1956-1961). Rio de Janeiro: Editora Fiocruz/EDUEPB/Fino Traço, 2013.

MYRDALL, G. Economics aspects of health. WHO Cronicle, 6(7-8): 224-242, 1952.

PACKARD, R. M. The Making of a Tropical Disease: a short history of malaria. Baltimore: Johns Hopkins University Press, 2008.

PACKARD, R. M. G BROWN, P. J. Rethinking health, development, and malaria: historicizing a cultural model in international health. Medical Anthropology, 17(3): 181-194, 1997.

PAGLIARO, H.; AZEVEDO, M. G SANTOS, R. V. Demografia dos povos indígenas no Brasil: um panorama crítico. In: PAGLIARO, H.; AZEVEDO, M. M. G SANTOS, R. V. (Orgs.). Demografia dos Povos Indígenas no Brasil. Rio de Janeiro: Editora Fiocruz, 2005.

PAIVA, C. H. A. A saúde pública em tempos de burocratização: o caso do médico Noel Nutels. História, Ciências, Saúde-Manguinhos, 10(3): 827-851, 2003.

PAZ, M. C. Noel Nutels: a política indigenista e a assistência à saúde no Brasil Central (1943-1973), 1994. Dissertação de Mestrado, Rio de Janeiro: Instituto de Medicina Social, Universidade do Estado do Rio de Janeiro.

PENA, M. V. J. Saúde nos planos governamentais. Dados - Revista de Ciências Sociais, 16: 69-96, 1977.

PENNA, B. O Saneamento do Brasil. Rio de Janeiro: Editora dos Tribunais, 1918.

REBELO, F.; MAIO, M. C. G HOCHMAN, G. O princípio do fim: o torna-viagem, a imigração e a saúde pública no Porto do Rio de Janeiro em tempos de cólera. Estudos Históricos, 24(47): 69-87, 2011.

RIST, G. The History of Development: from Western origins to global faith. London: Zed Books, 2002.

SÁ, D. M. A voz do Brasil: Miguel Pereira e o discurso sobre o imenso hospital. História, Ciências, Saúde - Manguinhos, 16(supl.1): 333-348, 2009.

SÁ, D. M.; SÁ, M. R. G LIMA, N. T. Telégrafos e inventário do território no Brasil: as atividades científicas da Comissão Rondon (1907-1915). História, ciências, saúde-Manguinhos, 15(3): 779-810, 2008.

SANTOS, R. V. et al. Saúde dos povos indígenas e políticas públicas no Brasil. In: GIOVANELLA, L. et al. (Orgs.). Políticas e Sistema de Saúde no Brasil. Rio de Janeiro: Editora Fiocruz, 2008. 
SANTOS, W. G. Cidadania e Justiça. Rio de Janeiro: Campus, 1979.

SILVA, R. Malária e Desenvolvimento: a saúde pública no governo JK (1956-1961), 2008. Tese de Doutorado, Rio de Janeiro: Programa de Pós-Graduação em História das Ciências e da Saúde, Casa de Oswaldo Cruz, Fundação Oswaldo Cruz.

SOUSA, A. B. L. G SCHWEICKARDT, J. C. O Sesp nunca trabalhou com índios: a (in)visibilidade dos indígenas na atuação da Fundação Serviços de Saúde Pública no estado do Amazonas. História, Ciências, Saúde - Manguinhos, 20(4): 1635-1655, 2013.

SOUZA LIMA, A. C. O governo dos índios sob a gestão do Serviço Nacional de Proteção aos Índios. In: CUNHA, M. C. (Org.). História dos Índios no Brasil. São Paulo: Companhia das Letras, 1992.

SOUZA LIMA, A. C. Um Grande Cerco de Paz: poder tutelar, indianidade e formação do Estado no Brasil. Petrópolis: Vozes, 1995.

STEPAN, N. L. A Hora da Eugenia: raça, gênero e nação na América Latina. Rio de Janeiro: Editora Fiocruz, 2004.

VIEIRA, T. R. No coração do Brasil, uma capital saudável: a participação dos médicos e sanitaristas na construção de Brasília (1956-1960). História, Ciências, Saúde - Manguinhos, 16(supl. 1): 289-312, 2009.

WINSLOW, C.-E. A. Lo que Cuesta la Enfermidad y lo que Vale la Salud. Washington, D.C.: Organización Mundial de la Salud, Oficina Sanitaria Panamericana, 1955. (Publicaciones Científicas, v. 16). 


\section{O SUS e a Saúde Indígena: matrizes políticas e institucionais do Subsistema de Saúde Indígena ${ }^{1}$}

Luiza Garnelo

O mote deste capítulo é a análise do contexto político e institucional que configurou o Subsistema de Saúde Indígena, aqui entendido como produto de uma política social. ${ }^{2}$ Toma-se como ponto de partida e eixo analítico a trajetória do Sistema Único de Saúde (SUS), percorrendo temas e problemas relevantes na construção das políticas de saúde, das quais a Política de Saúde Indígena é tributária, explorando as conexões, as interfaces e os desencontros dessas duas políticas setoriais. Propõe-se também mapear atores e processos que propiciaram a emergência da Política Nacional de Atenção à Saúde dos Povos Indígenas (PNASPI), assinalando ainda a interveniência de relações internacionais que influenciam certos temas da política pública brasileira, incidindo particularmente sobre as políticas indigenista e ambiental, as quais têm sido objeto de interesse e intervenção de organismos multilaterais, como, por exemplo, o Banco Mundial.

Dado o mosaico institucional que propiciou a emergência da PNASPI, cabe interrogar como vem se dando seu processo de implantação e de geștão, tanto interno ao subsistema quanto nas interações com outros níveis do SUS.

Autores como Fleury e Ouverney apontam alguns elementos que auxiliam na compreensão da dinâmica de gestão de uma política de saúde. Dentre estes, consideram relevantes:

a definição das finalidades da política; a construção e o emprego de estratégias, planos e instrumentos técnicos que orientem a ação; o desenvolvimento de relações sociais e o desempenho de papéis políticos pelos agentes da política social; a construção de arenas e rotinas que orientem o processo decisório e a implementação dos planos de ação; assimilação ou compatibilização dos distintos projetos políticos que coexistem numa política posta em curso; formação e difusão de valores éticos de justiça e igualdade fomentados ou potencializados pela política social (Fleury G Ouverney, 2008: 41)

Ainda que não seja possível empreender-se uma análise exaustiva de todos esses elementos, pode-se refletir sobre as finalidades da política indigenista - criada no início do século XX com a incumbência de integrar e assimilar 
as populações nativas à sociedade colonizadora dominante - em contraponto com as finalidades da PNASPI, uma política produzida num mundo contemporâneo no qual a ideia de respeito às diferenças culturais passou a ser um vetor proeminente na cena social.

Assim, se no início do século passado era considerada humanitária e aceitável a ideia de assimilar as sociedades indígenas de modo a que não atrapalhassem o progresso, no fim dele tal posicionamento passou a ser amplamente rejeitado. A mudança de mentalidade na sociedade brasileira permitiu a afluência dos princípios constitucionais que fundamentam uma política pública como a PNASPI, efetivando a garantia do direito à diferença étnica.

As ideias contidas neste capítulo podem ser entendidas como um estudo exploratório apoiado em pesquisa bibliográfica e documental sobre a gestão em saúde indígena, no período compreendido entre 1999 e 2011. A pesquisa bibliográfica priorizou os bancos de dados do PubMed, a biblioteca virtual SciELO (periódicos e SciELO Livros). Procedeu-se à seleção dos Descritores em Ciências da Saúde (DeCS) adequados ao processo de busca e iniciou-se a busca dos artigos com os termos: "políticas sociais", "políticas públicas", "gestão pública", "focused social politics", "regionalização", "descentralização", "universalização", adicionando-se "AND saúde" e "AND indígena" em todos os índices.

A investigação documental compreendeu a busca, a leitura e a categorização de documentos institucionais que ainda não tivessem recebido tratamento analítico gerador de publicações científicas (Appolinário, 2009). As principais fontes documentais foram registros institucionais escritos, tais como leis, decretos e portarias que regulamentam a operacionalização do Subsistema de Saúde Indígena, com ênfase nos dispositivos que tratassem da gestão da atenção à saúde nos Distritos Sanitários Especiais Indígenas (DSEIs) e nos níveis centrais da Fundação Nacional de Saúde (Funasa) e da Secretaria Especial de Saúde Indígena (Sesai). Nesse âmbito, a pesquisa dos dados foi conduzida de acordo com as proposições de Baptista (2007) para análise de portarias, categorizando-as segundo o tema regulamentado.

Também foram investigados os planos plurianuais (PPA) para os períodos de 2000-2003, 2004-2007 e 2008-2011, bem como seus relatórios de gestão, principalmente nos itens que tratavam da temática indígena. Documentação correlata também foi investigada, como a Agenda Social e um importante relatório de auditoria do Tribunal de Contas da União (TCU) sobre a Funasa, que teve influência significativa na decisão de repassar, da Funasa para a Sesai, a responsabilidade pela operacionalização do Subsistema de Saúde Indígena.

O tratamento dos dados seguiu as premissas da análise de conteúdo (Bardin, 1979), compreendendo uma apreensão global preliminar dos documentos selecionados (pré-análise), seguida pela exploração do material com base na análise da lógica interna dos conteúdos dos textos, que foram identificados, numerados 
e categorizados. Por fim, efetuou-se o tratamento dos dados a fim de gerar juízos válidos e significativos sobre o material coletado, o qual foi sistematizado mediante consonância com a bibliografia adotada para subsidiar a pesquisa (Cellard, 2008).

Os mesmos princípios e procedimentos orientaram a busca em páginas da web de órgãos oficiais que publicam textos, normas técnicas, dispositivos legais e outras formas de demonstração pública de suas atividades. Foram consultadas páginas do Senado, da Fundação Nacional do Índio (Funai), do Ministério Público, do TCU, do Instituto de Estudos Socioeconômicos (Inesc) e do Instituto de Pesquisa Econômica Aplicada (Ipea), tendo-se definido como período de análise o intervalo compreendido entre os anos 1999 e 2011. Ao longo da pesquisa foram realizadas de duas a quatro consultas às páginas institucionais de interesse, sendo a última em dezembro de 2011.

\section{Breve Cronologia das Fases de Implantação do Subsistema de Saúde Indígena}

Os principais eventos que caracterizam a implantação e a operacionalização da Política Nacional de Atenção à Saúde Indígena e de seu subsistema já foram objetos de discussão e análise de diversos pesquisadores (Aith, 2009; Varga, 1992; Varga G Adorno, 2001; Garnelo, Macedo G Brandão, 2003; Garnelo, 2006; Verdum, 2005; Santos et al., 2008; Landgon, 2007; Langdon G Diehl, 2007; Athias G Machado, 2001; Pontes G Garnelo, 2010). Tomando como base esses autores, serão resumidos alguns aspectos da dinâmica de gestão do Subsistema de Saúde Indígena, visando a situar o leitor nos principais eventos correlatos à implantação da PNASPI.

A realização da $1^{\text {a }}$ Conferência de Saúde Indígena, em 1986, destacou a necessidade de se garantir estratégias diferenciadas de atenção à saúde dessas minorias e a importância de vinculá-las ao SUS. Nas $2^{\mathrm{a}}$ e $3^{\mathrm{a}}$ Conferências Nacionais de Saúde Indígena, realizadas em 1993 e 2001, discutiram-se o modelo assistencial em saúde indígena, sua operacionalização por meio de distritos sanitários e o papel dos agentes indígenas de saúde, cujo perfil de atuação também foi delineado. Nelas também se reafirmou a importância do gestor federal como condutor do Subsistema de Saúde Indígena, em oposição à ideia de municipalização de assistência à saúde, hegemônica no SUS.

No intervalo entre a $3^{\mathrm{a}}$ e a $4^{\mathrm{a}}$ Conferências, foi instituída e regulamentada a PNASPI, pela portaria n. 254/2002, integrando-a à Política Nacional de Saúde. Em 2006, a $4^{\text {a }}$ conferência teve como foco a avaliação do desenvolvimento operacional do Subsistema de Saúde Indígena e a situação de saúde da população atendida pelos DSEIs. 
No período compreendido entre 1991 e 2010, ressalvado o intervalo de vigência do decreto n. 1.141/2004, as ações do Subsistema de Saúde Indígena estiveram a cargo da Funasa, ${ }^{3}$ órgão ao qual coube a implantação e a operacionalização das ações de saúde indígena em todo o território nacional. Criada no fim de 2009, a Sesai, só foi efetivada em 2010, por meio da medida provisória n. 483/ 2010. No mesmo ano foi promulgada a lei n. 12.314, que dispôs sobre a reorganização da estrutura administrativa da Presidência da República, de ministérios e secretarias de governo. Ela incorporou as disposições da medida provisória n. 483/2010 e transferiu a estrutura do Subsistema de Saúde Indígena da Funasa para a recémcriada Sesai/MS.

\section{Cidadania, Políticas Sociais e a Questão Indígena}

Fleury e Ouverney (2008) problematizam as precondições para a existência das políticas sociais - entre as quais a de saúde - características do mundo moderno. Para os autores, o surgimento da política social como um direito coletivo está ligado à emergência da cidadania, isto é, à existência de uma comunidade política, na qual os indivíduos são concebidos como participantes, iguais em direitos e deveres, na gestão da vida pública, e também partilham de crenças no que se refere à pertinência desse estado de coisas. Assim, tais políticas seriam expressão concreta do direito dos cidadãos no interior de uma sociedade nacional.

Porém, no caso de minorias étnicas, embora a cidadania represente um direito e um tipo de proteção social, ela também pode significar uma forma de homogeneizar o mundo indígena aos modos de vida da sociedade nacional, podendo ainda induzir à adoção de valores e comportamentos do grupo social hegemônico, em detrimento da diferenciação étnica.

Ao longo da história, a formação das nações tem-se dado à custa da abolição de singularidades, especificidades e lealdades locais, isto é, da renúncia à identidade e solidariedade entre grupos comunais, num processo que raramente garantiu uma inserção igualitária das minorias às sociedades nacionais. Bourdieu (1996), que analisou algumas das facetas da formação dos Estados nacionais na Europa, demonstrou que sua transformação em centros de poder se deu à custa de amalgamar a diversidade do tecido social, resultando na abolição forçada das distinções entre grupos sociais que se tornaram minoritários ao longo do processo de consolidação dos Estados-nação modernos. Apenas muito recentemente, e de forma tímida, surgiu na história mundial a ideia de cidadania plural, capaz de preservar o direito à diferença étnica.

Fleury e Ouverney (2008) também argumentam que a noção de cidadania que universaliza e uniformiza direitos e deveres é, em certa medida, contraditória 
com a estrutura da economia capitalista, fundamentada na desigualdade entre os membros da sociedade. A tensão entre capitalismo e cidadania tem sido equacionada por meio de uma negação deliberada da existência das assimetrias econômicas estruturais e da iniquidade de acesso aos direitos sociais entre os membros da sociedade. Assim, o desenvolvimento da noção de cidadania, ao estabelecer direitos e deveres iguais para indivíduos supostamente livres e iguais, representaria uma forma de escamotear as assimetrias estruturais do regime capitalista.

Os mesmos autores consideram que as políticas de proteção social são produtos do capitalismo industrial tardio, que instituiu um sistema de relações contratuais em substituição às antigas relações comunais e familiares que ofereciam certo grau de proteção social. Na ausência destas, a instauração das modernas e impessoais relações baseadas no mercado e nos contratos de trabalho também gera a necessidade de um novo sistema de proteção social que, no Brasil contemporâneo, tem-se vinculado ao poder público.

Na história da política indigenista, a justificativa moral para a provisão de políticas de proteção social específicas para essas minorias étnicas - das quais a atenção diferenciada à saúde é apenas um caso particular - não se baseia no reconhecimento do direito de cidadania, e sim no reconhecimento de uma desigualdade histórica instituída pelo processo colonizatório, que gerou a necessidade da ação de Estado a fim de manter os índios relativamente a salvo, mas sem obstaculizar o progresso nacional (Souza Lima, 1987, 1995).

A trajetória do indigenismo sanitário pode ser cotejada com a tipologia das políticas de proteção social, caracterizadas por Fleury e Ouverney (2008) por meio dos modelos de assistência, seguro e seguridade.

De interesse para nosso argumento é o modelo de assistência social, regido pelo princípio da caridade, que, quando acionado, produz um tipo de status que discrimina e desqualifica seus beneficiários. Esse modelo dispõe de cobertura de tipo focal, e seu acesso é garantido apenas mediante a comprovação de que os meios dos beneficiários são inferiores àqueles acessíveis aos outros cidadãos. Tal sistema gera o que os autores chamam de cidadania invertida, ou seja: estigmatiza os beneficiários como incapazes, razão pela qual precisariam de proteção específica.

O outro tipo de política social apontado pelos autores, e relevante para a política de saúde indígena, é o da seguridade, que é o modelo que fundamenta a criação do SUS - pautado pelo princípio da justiça social. Este tem, entre seus efeitos, a ampliação da capacidade redistributiva dos bens disponíveis na sociedade, gerando um status de direito de cidadania. Provê cobertura universal dos serviços que disponibiliza e garante o acesso a todos os cidadãos em função de suas necessidades.

Os modelos de política social aqui sumarizados expressam os dois tipos de políticas sanitárias disponíveis para a população indígena no Brasil. A ação indigenista clássica ofertou atendimento à saúde, efetivado pelo Serviço de Proteção aos 
Índios (SPI) e pela Funai, mediante um modelo do tipo assistência social que, aliás, foi usado no país não apenas para as minorias étnicas, mas também para enquadrar e disciplinar os pobres, os desviantes e a população rural. Na política indigenista anterior à Constituição de 1988, o acesso às ações de saúde só era garantido aos grupos indígenas submetidos à tutela do órgão indigenista, ou seja, aqueles considerados juridicamente incapazes. A comprovação de sua identidade étnica pelos representantes do Estado seria a principal forma de habilitá-los como beneficiários das políticas assistenciais do poder público brasileiro.

Nesse caso, a recepção de benefício seria dependente do poder discricionário de um funcionário que atestasse o enquadramento de um grupo ou de um indivíduo nos requisitos estabelecidos pelo órgão indigenista. Mais do que o não reconhecimento de um direito de cidadania, esse modelo instituiu uma permanente situação de carência e de incapacidade, que passou a ser associada à condição étnica. Na sociedade brasileira, tal condição tende a ser periodicamente questionada pelos grupos hostis às minorias indígenas, de modo que estas precisam reafirmar periodicamente sua condição de dependentes do Estado para fazer jus às políticas assistenciais a elas dirigidas.

A Constituição de 1988 promoveu uma alteração radical nesse estado de coisas ao instituir o reconhecimento do direito dos indígenas, não por uma condição de tutelados vulneráveis, mas sim pela ancestralidade de sua presença no território hoje ocupado pela nação brasileira. Essa mudança de estatuto jurídico alicerçou a criação do Subsistema de Saúde Indígena, regido pelo modelo da seguridade que garante ao índio o direito de receber um atendimento diferenciado.

Entretanto, a transição entre os dois modelos de política social é um processo lento. O que se observa hoje no cenário indigenista é uma condição híbrida em que coexistem as duas estratégias de proteção social, configurando uma matriz institucional mista que fundamenta o modelo de indigenismo sanitário atualmente vigente. Apesar dos avanços, persiste o pressuposto fundante da própria ação indigenista: o indígena não tem a possibilidade de buscar atenção à saúde por seus próprios meios, razão pela qual necessita de uma política compensatória de proteção social.

No período subsequente à Constituição de 1988, a adoção do direito ao autorreconhecimento tornou a definição da identidade étnica algo mais fluido, cujos limites são reiteradamente testados pelo crescente movimento de re-etnização de populações antes não reconhecidas como indígenas, algo que é mais perceptível no Nordeste do país. A abolição do monopólio estatal do direito a reconhecer quem é indígena e quem não é remeteu aos próprios grupos o direito - e a responsabilidade de definir quem pode ter acesso às políticas diferenciadas de proteção social.4

Todavia, a tradução desse princípio ético-político em ações concretas, como as de educação e de saúde, causa dificuldades para os órgãos públicos que atuam de modo rígido, estipulando cálculos de metas por beneficiários e de custos equi- 
valentes (Verdum, 2005, s.d.), mostrando-se incapazes de acompanhar a fluidez da identidade étnica. Essa dinâmica identitária, por sua vez, implica elevado grau de flutuação dos indicadores demográficos, na medida em que aos fatores biológicos de crescimento da população adicionam-se dimensões políticas que alteram com muita rapidez o perfil demográfico esperado, o que também dificulta a programação adequada de coberturas assistenciais pelo sistema de saúde.

Ainda que a Constituição de 1988 tenha restringido o autoritarismo do órgão indigenista, ela não propiciou a instalação de um pacto social que favorecesse a geração de consensos sobre os beneficiários das políticas sociais culturalmente específicas. Na ausência de critérios claros sobre o perfil dos destinatários das políticas diferenciadas, predominam as conjunturas locais e as correlações de forças instituídas entre os grupos indígenas e o poder público. Uma alternativa possível para esse dilema seria abolir a necessidade de se comprovar a identidade indígena ao garantir o acesso às políticas de saúde por meio da universalização da assistência. Esse foi o caminho adotado pelo SUS quando optou pelo modelo da seguridade social e não pelo modelo de seguro saúde, para cujo acesso o beneficiário necessitaria comprovar vínculo empregatício e contribuição prévia ao sistema de seguro. Porém, para se adotar no subsistema o caminho da universalização, tal como no SUS, o preço a se pagar seria a abolição do princípio da diferenciação étnica que rege a própria existência de uma política específica para as minorias indígenas.

Outro vetor não equacionado nas políticas de saúde indígena é o caso das populações urbanizadas que, no atual estado de coisas, não gozam do direito à atenção diferenciada à saúde; a elas aplica-se o pressuposto implícito de que devam recorrer ao SUS como qualquer cidadão brasileiro. Esse problema não vem sendo enfrentado pelo subsistema, que tem direcionado preferencialmente suas ações para as populações que vivem no interior de terras demarcadas.

A discriminação dita positiva destinada a beneficiar grupos prejudicados por políticas sociais de caráter homogeneizante implica uma revisão do conceito de igualdade simples em favor de uma noção de igualdade complexa, em que diferenças de gênero, raça, etnia e outras devem ser tratadas como singularidades que demandam tratamento especial nas políticas sociais de caráter universalizante (Fleury G Ouverney, 2008). Esse conjunto de valores e objetivos díspares e de origens tão diversificadas pode ser considerado a matriz que orienta a configuração da atual PNASPI.

Nesse âmbito, a saúde indígena se relaciona diretamente com uma polaridade que perpassa a discussão sobre as políticas sociais no Brasil, que é a tensão entre universalismo e focalização dos seus beneficiários. 


\section{Focalização versus Universalização dos Direitos à Saúde}

Nos anos 1990, o princípio da universalidade foi reiteradamente questionado pelos dirigentes maiores do país, mais comprometidos com o ajuste fiscal do que com as propostas redistributivas de políticas sociais como o SUS, que tem como uma de suas diretrizes estruturantes esse princípio.

Costa (2009), entre outros autores, analisou as políticas sociais do período, marcadas pela chamada universalização restrita, equivalente, segundo ele, à focalização, ou seja, ao direcionamento das políticas sociais para os grupos mais desfavorecidos na estrutura econômica. Para o autor, tais estratégias estariam diretamente ligadas aos constrangimentos fiscais gerados pela política de estabilização monetária adotada pelo governo Fernando Henrique Cardoso (FHC) e mantida na década seguinte pelo governo Lula. A adoção dessa alternativa teria gerado, entre suas consequências, a restrição do sistema de proteção social abrangente, proposto pela reforma sanitária, e do financiamento do gasto público dirigido às políticas sociais, como a de saúde, particularmente no período Lula.

Costa (2009) faz uma análise comparativa das agendas sociais dos governos FHC e Lula. Para ele, ainda que FHC tenha inaugurado a agenda de focalização do investimento público em grupos vulneráveis, seu governo não teria interrompido, ou desacelerado, a descentralização federativa dos recursos para saúde e educação, em que pese a existência de uma agenda mais geral da reforma administrativa, que preconizava a redução do papel do Estado no país. Posição similar é encontrada em Draibe (2003), para quem o governo FHC logrou uma combinação equilibrada entre o enfrentamento da pobreza por meios de programas focais e a manutenção e diversificação de programas universais, característicos das políticas sociais como a educação e a saúde.

Já para o primeiro governo Lula, Costa (2009) demonstra que houve redução dos recursos destinados às políticas sociais de educação, saúde e saneamento, em concomitância à priorização do Programa Bolsa Família, caracterizado pelo autor como uma típica política de focalização, expressa na canalização dos investimentos sociais para os estratos mais pobres da população, como já dito anteriormente. Segundo o mesmo autor, e tomando como base de comparação o Produto Interno Bruto (PIB) do Brasil para o período, o governo Lula teria promovido uma redução nos gastos sociais do tipo universalista, como a saúde e a educação, em favor do programa de transferência de renda, em comparação aos investimentos feitos nos dois mandatos de FHC. É ainda Costa (2009) quem aponta para uma estagnação na evolução dos gastos sociais pelo governo federal, no período compreendido entre 2003 e 2009, associada não apenas à canalização dos recursos para o Bolsa Família, mas também à manutenção da política de superávit fiscal que continuou 
a ser conduzida pelos órgãos da área econômica, tendo mesmo se aprofundado no governo Lula.

Druck e Filgueiras (2007) e Marques e Mendes (2004, 2007), que fazem uma crítica ainda mais incisiva às iniciativas de focalização do governo Lula, também identificam uma continuidade entre as políticas macroeconômicas dos governos FCH e Lula e apontam a influência dessas políticas nos investimentos em políticas voltadas para a melhoria estrutural das condições de vida, dada a precedência atribuída ao pagamento da dívida externa. Enfatizam a ingerência exercida por instituições multilaterais, como o Fundo Monetário Internacional (FMI) e o Banco Mundial, para as quais o equacionamento da dívida externa demandaria a redução dos investimentos sociais - o que teria se traduzido, entre outras medidas, no direcionamento das políticas sociais para grupos extremamente vulneráveis. Para esses autores, o Programa Bolsa Família expressaria o eixo principal das estratégias de focalização no governo Lula.

Cohn (2005) também problematiza a universalidade, reconhecida como um direito básico de cidadania e um dos princípios estruturantes do SUS, e interroga sobre as interfaces entre esse direito e a estratégia de focalização adotada pelos governos nos anos recentes. A autora, porém, explora um ângulo diferente da questão, ao correlacionar o tema da focalização com a existência de desigualdades enfrentadas por grupos diferenciados na sociedade, tais como etnias, raças, mulheres e outros, que precisariam de proteção específica para o atendimento às suas necessidades.

Para Cohn (2005), há no Brasil uma ideia subjacente de que a pobreza seria o principal problema social, paulatinamente equacionado com a melhoria geral da renda da população. Esse posicionamento não atribuiria realce à existência de problemas específicos enfrentados pelas minorias. Nesse caso, a cidadania poderia ser entendida como um direito economicamente determinado, dependente da inserção dos indivíduos no mercado de trabalho, que garantiria o acesso às políticas de proteção social. Essa via interpretativa pressupõe que o desenvolvimento econômico geraria automaticamente o desenvolvimento social, uma tese que a história do capitalismo avançado provou ser falsa. A autora relembra que a flexibilização e a precarização do trabalho no capitalismo tardio vêm reduzindo a oferta e o acesso aos postos de trabalho, bem como às políticas de proteção social, o que pode ocorrer mesmo entre aqueles efetivamente empregados.

No entender de Cohn (2005), se no passado a vinculação a um posto de trabalho era um meio de prover o acesso aos direitos de cidadania, isso não seria mais uma realidade no mundo atual, em que as desigualdades sociais não são reduzidas pela via do trabalho e da contribuição de impostos. A autora reconhece que alguns grupos na sociedade necessitam de proteção específica das políticas sociais para a redução das desigualdades. Nesse sentido, ela entende que políticas sanitárias dirigidas às minorias não representam estratégias conflitantes com as lutas 
pela universalização dos direitos de cidadania, representando, ao contrário, modos de efetivar a universalização sem descurar das especificidades dos grupamentos sociais a quem as políticas públicas são dirigidas.

Todas essas abordagens remetem o campo da saúde indígena ao tema da focalização, seja pela inclusão dessas minorias nos investimentos dirigidos aos grupos em situação de alta vulnerabilidade, seja pelo reconhecimento de que suas singularidades culturais demandam estratégias específicas e políticas sociais diferenciadas. Nessas circunstâncias, a tensão entre universalização e focalização gerou uma conjuntura que oportunizou a inclusão e a visibilidade dos povos indígenas no campo das políticas de saúde no Brasil, além de maior participação no orçamento público destinado à satisfação de suas necessidades sanitárias.

No âmbito do SUS, orientado pelo princípio da universalização, a adoção de uma política de atenção diferenciada também implica certa relativização do princípio da equidade. Assim, a implantação do Subsistema de Saúde Indígena pode ser entendida como um tipo de discriminação positiva - uma ampliação da noção de equidade - na busca de ofertar oportunidades desiguais (maiores) àqueles que ocupam localizações menos privilegiadas no tecido social. Desse modo, o incremento das possibilidades de acesso das minorias aos serviços de saúde implica também ampliar suas possibilidades de usufruir dos direitos sociais já disponíveis para outros cidadãos.

Cabe lembrar, entretanto, que a existência do Subsistema de Saúde Indígena não é consensual no SUS. Ali, muitos ideólogos que abraçam a proposta da universalização rejeitam alternativas como a atenção diferenciada, por considerá-la um tipo de focalização de políticas públicas que deveriam ser dirigidas a todos indiscriminadamente. Tal desconhecimento - ou mesmo oposição, a depender do caso - das necessidades específicas das minorias étnicas tem dificultado a efetiva incorporação da temática indígena às instâncias maiores de decisão do SUS.

\section{Atores e Cenários Políticos Relevantes na Operacionalização da Política Nacional de Saúde Indígena}

Autores como Arretche (2005), Arretche e Vasquez (2009) e Cortes (2009), ao estudarem a implantação e a operacionalização do SUS, relembram que a política de saúde, tal como outras políticas públicas, é produto da conjunção de forças díspares (burocráticas, empresariais e de outros grupos de interesse), não raro conflituosas, cuja interação gera produtos novos, mas não necessariamente coincidentes com as correntes de poder e influência que lhes deram origem (Jobert G Muller, 1987; Muller, 1990). Sendo uma política social, a política de saúde é estritamente

ligada ao contexto em que se desenvolve. É dependente dos mediadores sociais - ou 
seja, dos agentes políticos que pensam, propõem e agem visando a operacionalizar determinada ação social, em busca de solucionar problemas priorizados pela sociedade, num período definido de tempo (Arretche G Vasquez, 2009).

É Arretche quem remete os princípios e modelos que configuram o SUS à história política do Brasil; ela demonstra que, ao longo do tempo, o governo federal emergiu como vetor principal de tomada de decisão, instituindo-se como instância de maior acumulação de capacidades gerenciais e técnicas, em comparação com os níveis estaduais e municipais de gestão. Para a autora, esse movimento é congruente com a tendência brasileira à centralização do poder, agravada pela sucessão de governos autoritários que canalizaram o poder de mando para o nível central de governo e garantiram seu protagonismo na gestão das políticas de saúde. Nessa conjuntura, boa parte do movimento da Reforma Sanitária pode ser interpretada como uma luta em favor da descentralização ${ }^{5}$ de verbas e de poder de decisão para os níveis locais (Arretche, 2003, 2005; Arretche G Vazquez, 2009).

A tensa relação entre esses níveis de governo caracteriza o que Arretche e Vazquez (2009) denominam de "um conflito federativo", entendido como algo inerente à própria estrutura do SUS. Na interação de instâncias locais, como o poder municipal, estas sempre buscam ampliar sua participação no processo decisório e obter, das fontes federais, financiamento para as ações de saúde. Já o nível federal, representado pelo Ministério da Saúde, tenderia a agir visando a manter sua prerrogativa de definir os rumos da ação sanitária e a reduzir progressivamente sua participação no financiamento das ações de saúde.

O cenário descrito por Arretche para o SUS como um todo é de particular interesse para o entendimento da Política de Saúde Indígena. Nesse campo, vários são os mediadores sociais que precisam ser apreendidos e incorporados na análise. Dentre eles, são relevantes os protagonistas do indigenismo clássico, que moldaram a ideia de que o governo federal seria o único agente capaz de operacionalizar adequadamente uma política pública dirigida aos povos indígenas no Brasil. Outros atores políticos de interesse são os sanitaristas partidários da doutrina do SUS que aportaram as propostas da atenção primária à saúde aos princípios do indigenismo e vêm lutando pela incorporação da temática indígena na agenda nacional da política de saúde (Garnelo, Macedo G Brandão, 2003; Varga, 1992, 2010).

Igualmente relevantes - e com forte capacidade de interveniência - são o Banco Mundial e as organizações não governamentais (ONGs) do movimento ambientalista que vincularam a questão indígena à temática da preservação ambiental, exercendo presença marcante nas políticas públicas voltadas para as minorias étnicas no Brasil.

No Brasil, a década de 1990 foi a de maior afluência das ONGs. Essas entidades, atuantes nos mais diversos tipos de políticas sociais, tiveram papel bastante relevante na configuração e na operacionalização do Subsistema de Saúde Indígena. Tanto atuaram no assessoramento ao movimento indígena, que emergiu como ator 
político-reivindicatório no controle social do indigenismo sanitário, quanto capitanearam denúncias, em níveis nacional e internacional, que forçaram respostas do poder público visando a promover a melhoria das condições de saúde das minorias étnicas (Verdum, 2009a; 2009b).

A presença das ONGs também se revelou importante no processo de compra de serviços de terceiros (terceirização) ${ }^{6}$ pelo governo federal, uma vez que várias entidades de defesa dos direitos à diferença étnica estabeleceram, nos anos seguintes à implantação do Subsistema de Saúde Indígena, convênios com a Funasa para efetuar a prestação de serviços de saúde aos povos indígenas, em diversas regiões do país. A atuação dessas entidades se concentrou principalmente na Região Amazônica, o que pode ser entendido como um reflexo da vinculação entre as lutas pela preservação da floresta e dos povos que nela vivem (Garnelo $G$ Sampaio, 2005; Varga, 2010).

A globalização da base econômica em escala planetária favoreceu a afluência de instituições supranacionais com interveniência nas políticas internas dos Estados-nação; é o caso do Banco Mundial, do Banco Interamericano de Desenvolvimento e de agências do Sistema Nações Unidas, como a Organização das Nações Unidas para a Educação, a Ciência e a Cultura (Unesco), a Organização Internacional do Trabalho (OIT), a Organização Mundial da Saúde (OMS)/Organização PanAmericana da Saúde (Opas) e o Programa das Nações Unidas para o Desenvolvimento (Pnud) que também têm desempenhado papel relevante no campo da saúde.

Viana e Baptista (2008) formularam uma tipologia dos modelos de análise de políticas públicas, na qual destacamos o chamado improved model, em que exploram a ideia de que o contexto da política internacional molda a seleção e a priorização de certos problemas e a inibição de outros na ação de Estado, bem como direciona ações de defesa (advocacy) de causas percebidas como prioritárias pela opinião pública mundial. Este é o caso específico das lutas pela preservação ambiental e pelos direitos das minorias étnicas, aqui analisadas (Verdum, 2009c; Oliveira Filho, 2000).

As mesmas autoras identificam uma crescente influência do Banco Mundial no período compreendido entre 1980 e 2000, particularmente na proposição de medidas de ajuste fiscal de países devedores e redirecionamento do investimento em políticas sociais para os grupos mais desfavorecidos da sociedade. Nesse âmbito, - Banco surge como uma força contrária ao princípio da universalização do SUS. Já no campo específico da saúde indígena, ele desponta como um agente de incentivo e financiamento que induz à priorização das políticas sociais voltadas para grupos considerados vulneráveis. ${ }^{7}$

No período antecedente à Lei Arouca, quando a Funasa desfrutava de precária legitimidade para exercer a gestão da política de saúde indígena, o Banco Mundial teve importante participação nesta política para minorias, na medida em que incorporou a temática - com o respectivo financiamento das ações ali pactuadas - ao 
ambicioso Programa de Controle da Malária na Amazônia (PCMAM). O componente de saúde indígena albergado no PCMAM contemplava não apenas o controle da malária, mas também um amplo conjunto de ações de atenção primária à saúde (APS) que foram as primeiras efetivamente executadas pela Funasa em favor das populações indígenas logo após a criação desse órgão (Confalonieri et al., 1993). O Banco Mundial igualmente financiou o primeiro diagnóstico sistemático sobre o perfil epidemiológico da população indígena brasileira visando a subsidiar a tomada de decisão (Confalonieri et al., 1993). O diagnóstico foi produzido, contudo não se observou interesse dos dirigentes da Funasa em utilizá-lo como auxílio à tomada de decisão. Alguns programas que sucederam o PCMAM, tais como o Projeto Vigisus I e II e outros, também priorizavam as populações indígenas e representaram um significativo aporte de recursos adicionais às fontes orçamentárias rotineiras disponibilizadas para a Funasa.

A partir da Constituição de 1988, os povos indígenas emergiram também como vetores políticos importantes, senão de proposições, pelo menos de reivindicações e de poder de veto a certas iniciativas do governo central, bem como dos DSEIs. ${ }^{8}$ Tais iniciativas receberam importante reforço do Ministério Público, que tem atuado na defesa dos direitos das minorias étnicas e no monitoramento da atuação dos governantes (Dodge, 1998, 2001).

Por fim, os políticos locais e os sistemas municipais de saúde têm surgido no cenário mais como elementos que obstaculizam do que favorecem a concretização de um subsistema específico para as minorias étnicas. A interveniência desses atores tem se dado mais pela demanda de recursos financeiros da União do que por uma resposta assistencial efetiva às populações indígenas que vivem em seus territórios. Existem poucas publicações sobre a atuação dos municípios no campo da saúde indígena, mas a informação disponível (Chaves, Cardoso G Almeida, 2006; Varga, 2007; Varga G Vianna, 2009; Garnelo G Escobar, 2007) indica que esses sistemas locais de saúde não têm ofertado respostas adequadas às atribuições que concordaram em assumir na prestação de serviços aos povos indígenas.

A movimentação técnico-política dos agentes institucionais que deliberam sobre uma política pode ser apreendida por meio dos dispositivos legais e de normas técnicas que disciplinam e orientam sua operacionalização. Essa via tem sido explorada por autores como Baptista (2007), cuja análise de portarias ministeriais propiciou uma produtiva reflexão sobre a dinâmica da gestão do SUS e do subsistema indígena. Em consonância com as orientações de Baptista, ${ }^{9}$ efetuou-se a análise de planos e projetos de gestão e administração maior do governo federal, bem como do SUS e de seu subsistema, além da leitura de leis, decretos, portarias e instruções normativas que tratam da saúde indígena. Esses dispositivos legais já configuram um conjunto expressivo de documentos que cobrem um período compreendido entre o início dos anos 1990, antecedendo a promulgação da Lei Arouca, até 2010, ano de criação da Sesai. 
Seguindo a classificação de Baptista (2007), tanto a lei n. 9.649/1998 (que dispôs sobre as obrigações do SUS e incluiu a saúde indígena entre as responsabilidades do Ministério da Saúde) quanto a lei n. 9.836/1999 (Lei Arouca), a lei n. 11.784/2008 (que dispôs sobre Plano de Cargos do Poder Executivo, contemplando os cargos disponibilizados para a saúde indígena), a lei n. 12.314/2010 (que transferiu a estrutura de saúde indígena da Funasa para o Ministério da Saúde, antecedendo a criação da Sesai) e a medida provisória n. 483/2010 são dispositivos de gestão e regulamentação do sistema. No caso do Subsistema de Saúde Indígena, pode-se dizer que parte dessa legislação trata da criação de suas estruturas, além da deliberação sobre sua gestão e regulamentação.

Enquadramento similar pode ser dado aos decretos: GM/MS n. 3.157/1999 (que dispôs sobre as condições para a prestação de assistência à saúde dos povos indígenas, no âmbito do SUS); GM/MS n. 23/1990; GM/MS n. 1.141/1994, cujo teor já foi analisado; n. 3.799/2001 (que alterou o decreto n. 1.141); GM/MS n. 4.727/2003 (que aprovou o Estatuto da Funasa, mencionando suas atribuições na saúde indígena); GM/MS n. 6.878/2009 (que alterou o decreto n. 4.727/2003 e aprovou novo Estatuto e Quadro Funcional da Funasa, com referências às suas atribuições na saúde indígena, além de conceder autonomia administrativa e financeira dos DSEIs, ainda no âmbito da Funasa); ${ }^{10}$ GM/MS n. 7.135/2010 (que criou nova estrutura regimental do MS); e GM/MS n. 7.336/2010 (que alterou a estrutura regimental do $\mathrm{MS}$, incluindo a Sesai entre seus órgãos). O último decreto, já de 2011, foi o GM/MS n. 7.461/2011 (que ampliou o período de transição do repasse das ações de saúde indígena da Funasa para a Sesai).

Também vinculadas à temática da gestão e estruturação do Subsistema de Saúde Indígena, foram identificadas 19 portarias, 62\% de um total de 32 disponíveis no portal da Funasa (Quadro 1).

Quadro 1 - Portarias de gestão em saúde indígena

\begin{tabular}{|l|l|}
\hline Número e ano da portaria & \multicolumn{1}{c|}{ Teor - gestão e regulamentação do sistema } \\
\hline P. Funasa n. 852/1999 & $\begin{array}{l}\text { Cria os DSEIs e define suas competências, organização, gestão e seu } \\
\text { controle social. }\end{array}$ \\
\hline P. GM/MS n. 1.163/1999 & $\begin{array}{l}\text { Cria o Fator de Incentivo de Atenção Básica e aos Povos Indígenas e o } \\
\text { Fator de Incentivo para a Assistência Ambulatorial, Hospitalar e de Apoio } \\
\text { Diagnóstico à População Indígena. }\end{array}$ \\
\hline P. GM/MS n. 543/2001 & $\begin{array}{l}\text { Estabelece normas e procedimentos operacionais para concessão e aplicação } \\
\text { de suprimento de fundos especial, para atender às especificidades da } \\
\text { assistência à saúde indígena. }\end{array}$ \\
\hline P. GM/MS n. 254/2002 & Institui e regulamenta a PNASPI. \\
\hline P. GM/MS n. 70/2004 & Aprova as diretrizes de gestão da PNASPI. \\
\hline
\end{tabular}


Quadro 1 - Portarias de gestão em saúde indígena (cont.)

\begin{tabular}{|c|c|}
\hline Número e ano da portaria & Teor - gestão e regulamentação do sistema \\
\hline P. GM/MS n. 399/2006 & $\begin{array}{l}\text { Institui o Pacto pela Saúde e mantém os fatores de incentivo à saúde } \\
\text { indígena. }\end{array}$ \\
\hline P. Funasa n. 233/2006 & $\begin{array}{l}\text { Institui grupo de trabalho de reestudo da abrangência dos DSEIs com a } \\
\text { finalidade de promover o levantamento e a sistematização das demandas } \\
\text { de alteração da área de abrangência dos distritos existentes e da criação de } \\
\text { novos distritos. }\end{array}$ \\
\hline P. GM/MS n. 645/2006 & $\begin{array}{l}\text { Institui o Certificado Hospital Amigo do Índio, a ser oferecido aos } \\
\text { estabelecimentos de saúde que fazem parte da rede do SUS, com } \\
\text { representante do Departamento de Saúde Indígena (Desai)/Funasa. }\end{array}$ \\
\hline P. Funasa n. 1.057/200 & $\begin{array}{l}\text { Institui o Comitê Nacional de Farmácia e Terapêutica com abrangência no } \\
\text { Desai e Dsei. }\end{array}$ \\
\hline P. Funasa n. 2.656/2007 & Regulamenta os incentivos previstos na portaria n. 1.163/1999. \\
\hline P. GAB/MS n. 3.034/2008 & $\begin{array}{l}\text { Estabelece grupo de trabalho com o objetivo de discutir e apresentar novas } \\
\text { propostas, ações e medidas de gestão dos serviços de saúde oferecidos aos } \\
\text { povos indígenas. }\end{array}$ \\
\hline P. GAB/MS n. 3.035/2008 & $\begin{array}{l}\text { Retifica composição e atribuições do grupo de trabalho criado pela portaria } \\
\text { n. } 3.034 / 2008 \text {. }\end{array}$ \\
\hline P. Funasa n. 126/2008 & $\begin{array}{l}\text { Regulamenta o acompanhamento da execução física na Celebração e } \\
\text { Execução dos Convênios de Saúde Indígena. }\end{array}$ \\
\hline P. Funasa n. 293/2008 & $\begin{array}{l}\text { Estabelece critérios para celebração de convênios com entidades } \\
\text { governamentais e não governamentais para a execução das ações de } \\
\text { atenção à saúde dos povos indígenas. }\end{array}$ \\
\hline P. Funasa n. 274/2008 & $\begin{array}{l}\text { Regulamenta os estabelecimentos de saúde indígena no Cadastro Nacional } \\
\text { dos Estabelecimentos de Saúde (CNES). }\end{array}$ \\
\hline P. Funasa n. 382/2008 & Altera disposições da portaria n. 274/2008. \\
\hline P. GM/MS n. $1.235 / 2008$ & $\begin{array}{l}\text { Cria comissão para analisar necessidade de pessoal para atuar na } \\
\text { atenção básica aos povos indígenas e definir um perfil de atuação desses } \\
\text { profissionais. }\end{array}$ \\
\hline P. GM/MS n. 1.922/2008 & $\begin{array}{l}\text { Cria grupo de trabalho com o objetivo de discutir e apresentar proposta de } \\
\text { ações e medidas a serem implantadas no âmbito do Ministério da Saúde no } \\
\text { que se refere à gestão dos serviços de saúde oferecidos aos povos indígenas. }\end{array}$ \\
\hline P. GM/MS n. 2.048/2009 & $\begin{array}{l}\text { Regulamenta a nova estrutura de gestão do Ministério da Saúde e nela } \\
\text { inclui a saúde indígena. }\end{array}$ \\
\hline
\end{tabular}

Fonte: Elaborado pela autora com base nos dados disponíveis no site da Funasa (Brasil, 2014).

Ainda nesse conjunto de 32 dispositivos legais havia, na página da Funasa também em 2011, quatro portarias e uma resolução voltadas para a regulação do controle social: resolução MS/CSN n. 293/1999 (cria a Comissão Intersetorial de 
Saúde Indígena); portaria GM/MS n. 69/2004 (cria o Comitê Consultivo da Política de Atenção à Saúde dos Povos Indígenas); portaria Funasa n. 266/2004 (designa os membros integrantes do Comitê Consultivo criado na portaria n. 69/2004); portaria GM/MS n. 741/2004 (altera a composição do Comitê Consultivo da PNASPI, instituído pela portaria n. 69/2004); portaria GM/MS n. 644/2006 (institui o Fórum Permanente de Presidentes dos Conselhos Distritais).

A regulamentação da prestação de assistência aos povos indígenas foi objeto de apenas sete portarias no período pesquisado: portaria MS n. 1.163/1999 (dispõe sobre as responsabilidades na prestação de assistência à saúde dos povos indígenas); a P. MS n. 2.405/2002 (institui o Programa de Promoção da Alimentação Saudável em Comunidades Indígenas); portaria Funasa n. 984/2006 (institui o Sistema de Vigilância Alimentar e Nutricional nos DSEIs); portaria Funasa n. 1.420/2006 (institui grupo de trabalho encarregado de definir e implementar rede de serviços de saúde mental); portaria Funasa n. 1.476/2006 (aprova as Diretrizes para Atenção à Saúde Bucal nos Distritos Sanitários Especiais Indígenas); portaria Funasa n. 1.529/2006 (institui grupo de trabalho para estabelecer parâmetros para abastecimento, armazenamento, distribuição e remanejamento de medicamentos e correlatos, com o objetivo de implantar um Sistema Informatizado de Controle de Insumos pertinentes à saúde da população indígena); e portaria Funasa n. 883/2008 (institui as Comissões Nacional e Distrital de Investigação e Prevenção do Óbito Infantil e Fetal Indígena). Foi encontrada uma única portaria dirigida ao saneamento e infraestrutura (P. Funasa n. 479/2001, que regulamenta estabelecimentos de saúde e saneamento e estabelece diretrizes para a elaboração de projetos de estabelecimentos de saúde e de saneamento).

$\mathrm{O}$ teor desses dispositivos legais permite dizer que a categoria gestão e regulamentação do sistema mereceu grande interesse dos gestores, que geraram 33 instrumentos jurídico-administrativos voltados para instituição e regulamentação da gestão do Subsistema de Saúde Indígena. Em contrapartida, somente sete deles trataram de rotinas e práticas de assistência nos DSEIs. Rigorosamente falando, os cinco dispositivos normativos que tratam do controle social também representam instrumentos de gestão; se enquadrados nessa temática, o número de normativas direcionadas à gestão do subsistema passaria para um total de 38 , evidenciando uma super-regulamentação nesse campo. Porém, optamos por não enquadrá-los na categoria Gestão e Regulação do sistema, por entendermos que tais instrumentos regem processos distintos daqueles adotados no poder público para efetuar a administração interna de seus órgãos.

Além da predominância absoluta da temática de gestão e administração restrita ao nível central, foi possível observar que a grande maioria desses dispositivos voltou-se para a regulamentação intra Subsistema de Saúde Indígena. Dentre todos os documentos analisados, apenas o decreto n. 3.156/1999, a portaria n. 1.163/1999 (que criaram, respectivamente, o Fator de Incentivo de Atenção 
Básica e aos Povos Indígenas e o Fator de Incentivo para a Assistência Ambulatorial, Hospitalar e de Apoio Diagnóstico à População Indígena, passíveis de serem repassados para os municípios), e a portaria GM/MS n. 399/2006 (que se limitou a manter os termos dos já citados incentivos no texto do Pacto pela Saúde) denotaram esforço em promover interação técnica e administrativa entre o subsistema e outras instâncias do SUS.

A disposição inicial para promover a articulação desses dois níveis de gestão parece ter arrefecido nos anos subsequentes à Lei Arouca. Somente se observa a retomada dessa iniciativa com a portaria n. 2.656, já em 2007, que aprimorou a regulamentação dos recursos oriundos da Secretaria de Assistência à Saúde (SAS) e repassados diretamente aos municípios para cobrir os incentivos e outras atividades. Ela também regulamentou outras formas de interação entre o subsistema e outros níveis de gestão do SUS, definindo com maior clareza atribuições dos sistemas municipais e estaduais de saúde, bem como das comissões bipartite e tripartite na atenção à saúde indígena.

Curiosamente, a portaria n. 2.656/2007 foi interpretada pelo movimento indígena como uma forma de municipalização da PNASPI, embora ela apenas regulasse a destinação e o uso de recursos oriundos da SAS que já eram repassados aos municípios desde 1999. Sua publicação gerou numerosos protestos indígenas em várias regiões do país, repercutindo nas páginas da web de entidades de grande importância política, como a Coordenação das Organizações Indígenas da Amazônia Brasileira (Coiab), a Federação das Organizações Indígenas do Rio Negro (Foirn), o Conselho Indigenista Missionário (Cimi), o Instituto Socioambiental (ISA), que publicaram documentos de protesto das organizações indígenas. ${ }^{11}$

Não há meios de aquilatar se houve um equívoco de interpretação sobre a finalidade da portaria - que, afinal, atendia a várias reclamações anteriores por parte dos líderes indígenas - por falta de um adequado entendimento sobre os processos de gestão do SUS ou se a irritação das lideranças indígenas para com os problemas de gestão acumulados pela Funasa simplesmente encontrou um pretexto para eclodir. O certo é que a portaria continuou causando polêmica até sua revogação pelo decreto n. 7.336/2010. Esse decreto, que reestrutura a regulamentação e a gestão do SUS, simplesmente incluiu o teor da portaria n. 2.656/2007 nas suas disposições, mas sua publicação não gerou qualquer protesto. Ele teve também um significado relevante para a institucionalização da saúde indígena no SUS, não apenas por contemplar a criação da Sesai, mas também por demonstrar, de modo inequívoco, a incorporação do subsistema na estrutura principal do Ministério da Saúde e definir com clareza que o espaço da saúde indígena despontava como uma das prioridades da Política Nacional de Saúde.

A oscilação na disposição para instituir um entrelaçamento efetivo dos DSEIs com os sistemas municipais e estaduais de saúde - dos quais o subsistema 
depende para suprir atenção integral aos seus usuários - parece ter impedido que se estabelecessem pactos de gestão (quer no interior do subsistema, quer na sua relação com outras instâncias de gestão do SUS) capazes de definir metas e atividades que propiciassem melhoria do acesso e da efetividade da atenção prestada aos indígenas, particularmente para atendimento em unidades de alta e média resolutividades. Ela contribuiu também para manter a condição de isolamento do subsistema desde sua criação, em 1999. Tais medidas de articulação seriam ainda mais necessárias em realidades como a amazônica, em que a grande magnitude da população indígena gera a tendência de superposição entre ambos os sistemas de atenção, ampliando ainda mais a necessidade de se definirem com clareza os fluxos de assistência, de informação e vigilância epidemiológica que nunca ficaram devidamente estipulados na relação entre o SUS e seu subsistema.

\section{Federalismo, Descentralização, Terceirização: campos de tensão na implementação da Política de Saúde Indígena}

A política indigenista tem sido sempre tópico de ação exclusiva do governo federal, e um dos raros pontos de consenso no campo indigenista é o papel destacado do poder central. Ainda que sejam correntes as críticas ao tipo de indigenismo exercido pelo Estado brasileiro, não há dúvida sobre a preferência pela alocação do poder de decisão e execução da política indigenista no nível federal de governo.

Tal consenso sobre a função do governo central na política indigenista tem sido um dos eixos de orientação da Política de Saúde Indígena, cuja atribuição de responsabilidade sanitária é centrada no âmbito federal. Essa orientação representa uma das contradições fundamentais na relação entre o SUS e seu subsistema, cuja implantação se deu exatamente no momento em que a descentralização do SUS ganhava força e organicidade com a Reforma Sanitária em curso. A municipalização, tomada como um princípio estruturante do SUS, mostrou-se um obstáculo à organização do Subsistema de Saúde Indígena, uma vez que este se orientava num rumo oposto à descentralização instituída no país a partir da década de 1980 (Santos et al., 2008; Garnelo, Macedo G Brandão, 2003; Raggio, Pinto G Moraes, 2008).

A Lei Arouca gerou uma contradição essencial no fluxo de atuação do SUS, em face do protagonismo que ela atribuiu ao governo federal. O recém-criado subsistema encontrou um Ministério da Saúde desprovido de meios para executar ações de atenção primária à saúde nas aldeias e sem qualquer possibilidade de reversão a esse respeito, pois a descentralização do SUS vinha sendo efetivada a passos largos pela Reforma Sanitária. 
O pressuposto de que o governo federal seria o agente institucional mais adequado para gerir e operacionalizar as ações de saúde indígena não é congruente com as atuais atribuições do Ministério da Saúde, cujo perfil de atuação é mais afeto à gestão e ao monitoramento das ações sanitárias, as quais devem ser executadas pelos níveis estaduais e municipais de poder. Nessa conjuntura, o governo federal não foi capaz de dotar o Subsistema de Saúde Indígena de capacidade operacional para desempenhar suas atribuições legais.

A alternativa encontrada para tentar contornar o problema foi repassar para a Funasa - um braço operacional do Ministério da Saúde, nascido da junção entre a Fundação Serviço Especial de Saúde Pública (Fundação Sesp) e a Superintendência de Campanhas de Saúde Pública (Sucam) ${ }^{12}$ - a responsabilidade pela saúde indígena.

Ainda que as trajetórias e formas de atuação das duas instituições ${ }^{13}$ (ver também o capítulo 5 deste volume) apresentassem marcadas diferenças, ambas tinham em comum a adoção de um modelo de higienismo sanitarista, caracterizado pela verticalidade de ação de um órgão federal que institui suas próprias prioridades e cria assimetrias no plano local, seja no trato com a população - objeto a ser civilizado por meio da educação sanitária -, seja no trato com as instituições locais, entendidas como elementos secundários - ou incapazes - de conduzir adequada e eficientemente a ação sanitária. A pouca sensibilidade para com as características locais era expressa em um conjunto padronizado de ações de atenção médica, de enfermagem e de saneamento que orientavam a atuação da Fundação Sesp. Igual procedimento seguia a Sucam, com seus protocolos nacionais de campanhas para o controle de vetores e de comunicantes de doenças transmissíveis, cuja operacionalização transcendia qualquer especificidade do contexto. Esse modelo de atuação, antes hegemônico na saúde pública brasileira, foi historicamente superado pelo movimento da Reforma Sanitária, mas deixou profundas marcas no indigenismo sanitário e ainda continua a repercutir nas estratégias de operacionalização do Subsistema de Saúde Indígena.

Embora a ação tutelar conduzida pelo SPI também congregasse a responsabilidade sanitária pelos povos indígenas, as matrizes ideológicas e operacionais que a instituíam eram as mesmas que orientavam a ação do poder público com relação às populações rurais pauperizadas. Além disso, iniciativas como a do Serviço de Unidades Sanitárias Aéreas (Susa), criado por Noel Nutels para o atendimento dos indígenas, eram parte integrante do sanitarismo campanhista voltado para o controle de doenças transmissíveis. Este também moldou a proposta de atuação das equipes volantes de saúde (EVS) da Funai, anos depois (Costa, 1987).

Tanto a Fundação Sesp quanto a Sucam tiveram longa história de atuação na Amazônia e estiveram no centro da polêmica que envolveu a consolidação do território brasileiro e a construção de uma identidade nacional, mediada pela 
ocupação e civilização dos sertões povoados, em grande parte, pelas populações indígenas. Essas populações recebiam alguma cobertura do antigo Departamento Nacional de Endemias Rurais (DENERu) - uma das instituições que confluíram para a formação da Sucam -, o qual atuou em interface com o SPI por vários anos. Apesar disso, tanto a Sucam quanto a Fundação Sesp tiveram uma atuação marcada pela ignorância, ou desinteresse, das singularidades culturais das populações indígenas que atendiam. Tratava-se, afinal, de uma postura congruente com uma concepção estritamente biomédica e com uma intervenção tecnicista, alheia ao contexto sociocultural do processo saúde-doença14 (ver também os capítulos 3 e 5 deste volume).

Essa herança histórica não credenciava a Funasa como o órgão mais adequado para o trabalho com populações indígenas, tarefa que recebeu no mesmo ano de sua criação. A formação de um novo órgão não alterou o anacronismo técnico e político das duas entidades de origem. À medida que a Reforma Sanitária progredia, as atribuições da Fundação Sesp e da Sucam eram progressivamente repassadas aos sistemas municipais de saúde. Ainda que irreversíveis, tais iniciativas produziram considerável resistência por parte de dirigentes e servidores da Funasa. ${ }^{15}$

A extinção da Sucam e da Fundação Sesp expressa o vetor assumido na correlação de forças intrassetoriais que se enfrentaram no albor da Reforma Sanitária; ela representa um marco da transição entre o antigo sistema de saúde do Brasil e a emergência do SUS. A fusão pode ser entendida como uma tentativa de reestruturar um modelo de ação que estava em descompasso com as prioridades da nova política de saúde instituída no país a partir da metade dos anos 1980.

O período compreendido entre 1991, ano da publicação do decreto n. $23 / 1990$, e 1999, data da criação oficial do subsistema pela Lei Arouca, é pouco analisado pelos estudiosos da Política de Saúde Indígena. Trata-se, porém, de um período importante, porque nele se configurou boa parte dos problemas atualmente existentes no campo do indigenismo sanitário.

Analistas da política de saúde no Brasil (Uga et al., 2003; Carvalho, 2001; Cordeiro, 2001; Pasche et al., 2006; Diniz, 1996) informam que o governo Collor (1990 a 1992) caracterizou-se por forte oposição ao movimento de descentralização que vinha sendo impulsionado pela Reforma Sanitária. As iniciativas presidenciais incluíram o veto a diversos itens da Lei Orgânica de Saúde (lei n. 8.080/1990) e um gerenciamento autoritário do SUS, feito por meio da elaboração, à revelia do movimento sanitário, de normas técnicas - as chamadas normas operacionais básicas (NOBs) - no interior do Ministério da Saúde, que obstaculizavam a municipalização do sistema de saúde. Tais medidas reforçavam o poder do governo federal, promovendo a inversão de um dos princípios mais caros ao movimento sanitarista que lutava pela reforma da política de saúde.

Nesse cenário, a promulgação do decreto n. 23/1990, retirando da Funai a responsabilidade pelas ações de saúde indígena e repassando-a para o Ministério 
da Saúde, pode ser entendida como uma conjugação entre os interesses presidenciais, contrários à descentralização, e a história da política indigenista, pautada pelo protagonismo do governo federal na condução dessa política. Se no plano administrativo o decreto efetuou uma mera transferência das ações de saúde de um órgão federal (a Funai) para outro (o Ministério da Saúde), em termos políticos a entrada do Ministério da Saúde no campo do indigenismo sanitário promoveu uma mudança efetiva na história da política indígena, uma vez que inseriu as lutas pelos direitos das minorias étnicas na cena política da universalização pelo direito à saúde no Brasil.

A reação do órgão indigenista foi negativa, culminando em uma cascata de pressões e denúncias contra a Funasa, que assinalavam particularmente sua inexperiência no trato com a questão indígena. Tais denúncias escamoteavam o fato de que grande parte dos quadros dirigentes da saúde indígena que havia passado a atuar na fundação após o decreto n. 23/1990 era oriunda da Funai, tendo se transferido para o Ministério da Saúde a fim de coordenar o novo setor de saúde indígena.

Entre 1990 e 1999 a tensão entre as duas instituições foi bastante intensa, resultando na derrubada do decreto n. 23, que foi substituído pelo decreto n. 1.141/1994; este devolveu à Funai a responsabilidade sanitária pelos povos indígenas. Logo em seguida, porém, foi promulgada uma resolução normativa (n. 001/1994) que manteve a vinculação do Ministério da Saúde ao campo da saúde indígena para o desenvolvimento de ações preventivas nas aldeias. Esse jogo de decretos evidenciava mais as disputas de poder entre órgãos do governo federal do que qualquer racionalidade técnico-sanitária. O teor da resolução normativa n. 001/1994, que instituiu a divisão entre ações curativas (a serem executadas pela Funai) e as atividades de prevenção (a serem desenvolvidas pela Funasa), é um exemplo da flagrante contradição com o princípio da integralidade das ações de saúde, que desde a década de 1980 orientava a política de saúde no país (Garnelo, 2006).

Na vigência do decreto n. 23/1990, e antes da promulgação da Lei Arouca, o envolvimento da Funasa com o campo indigenista ocorreu principalmente na Amazônia, mais particularmente nos estados do Amazonas e de Roraima, com a implantação do DSEI Yanomami, posto que a motivação do governo Collor ao instituir tal decreto parece ter sido mais política do que sanitária.

No início dos anos 1990, a população Yanomami enfrentava uma grave epidemia de malária - ligada a uma maciça invasão garimpeira em suas terras, que ameaçava a própria existência desse grupo étnico (Varga G Adorno, 2001; CCPY, 2011). Tal situação gerou uma enxurrada de denúncias internacionais, desencadeando, entre outras medidas, uma movimentação do Banco Mundial, que financiava diversos projetos de desenvolvimento econômico na Região Amazônica. O Banco, que nos anos 1980 havia sido denunciado pelo investimento no chamado 
Programa Integrado de Desenvolvimento do Noroeste do Brasil (Polonoroeste), o qual afetou negativamente os povos indígenas em Rondônia e no Mato Grosso, passou a inserir nos contratos que regiam os empréstimos ao Brasil algumas cláusulas de salvaguarda das condições ambientais de territórios amazônicos, bem como de suas populações (Davis, 1993; Davis G Partridge, 1995). Ante a gravidade da situação dos Yanomami, tais salvaguardas foram acionadas, reforçando o fluxo dos que pressionavam as autoridades governamentais para operacionalizar medidas de proteção aos povos indígenas.

Dentre as respostas do governo Collor, destaca-se um conjunto de decretos que retiraram do órgão indigenista (Funai) várias atribuições ligadas às políticas sociais (saúde, educação, produção, meio ambiente), redistribuindo-as pelos ministérios equivalentes. Em consonância com a tendência federalizante do governo Collor e com o cenário de pressões sociais em prol dos Yanomami, a promulgação do decreto n. 23/1990 expressou a resposta do governo para o campo da saúde. Simultaneamente, foi criado o DSEI Yanomami para prover atendimento aos membros daquela etnia. Ainda que o decreto n. 23/1990 repassasse as ações de saúde indígena, em âmbito nacional, ao Ministério da Saúde, a extensão do atendimento aos outros povos, quer na Amazônia, quer em outras Regiões do país, não foi prevista na legislação sanitária então vigente, até a promulgação da Lei Arouca em 1999 (Garnelo, 2006).

Um olhar retrospectivo sobre a restrita abrangência geográfica das ações governamentais em saúde indígena nesse período reforça a ideia de que a movimentação das autoridades foi mais conjuntural e reativa ao momento político do que estrutural, no sentido de uma resposta permanente aos problemas sanitários enfrentados pelas minorias indígenas que vivem no país. No entanto, se a atuação da Funai foi considerada insatisfatória, a transferência de sua responsabilidade sanitária para um órgão que não dispunha de condições para executar suas atribuições a contento também não representou vantagem significativa para a melhoria da qualidade da prestação de serviços (CCPY, 2011).

Como o decreto n. 23/1990 não autorizou - nem regulamentou - a contratação de funcionários para atuação em saúde indígena, a entrada da Funasa no campo do indigenismo sanitário se fez mediante a contratação de mão de obra temporária para desenvolver as ações de saúde. Paralelamente, o desmantelamento da capacidade instalada da instituição progredia, em face da municipalização em curso e da perda de importância, no cenário nacional, do modelo federalista que caracterizava sua atuação.

O ingresso do Subsistema de Saúde Indígena na Funasa terminou por reforçar a permanência de um órgão pouco permeável às diretrizes do SUS e que continuou a atuar, apesar de ter sua extinção já deliberada na $9^{a}$ Conferência Nacional de Saúde, em 1992. Por sua vez, o modelo centralizado de gestão da Funasa, aliado 
à sua baixa capacidade operacional, não habilitou a entidade a promover a necessária extensão de cobertura às populações aldeadas, que, até então, não contavam com a assistência do SUS, nem a buscar alianças institucionais que viabilizassem a assistência com base no plano local/municipal (Varga G Adorno, 2001).

Essa configuração institucional definiu a base operacional do Subsistema de Saúde Indígena e gerou uma contradição que até hoje permanece obstaculizando a efetividade da sua intervenção: a de como conciliar um modelo federalista de atenção com um SUS de base municipal.

Ao contrário do SUS, que enfrentou importantes embates com a rede privada de serviços de saúde, na saúde indígena os grandes embates institucionais se deram entre dois entes do governo federal, a Funai e a Funasa. Nos anos subsequentes, com a retirada da Funai de cena, as divergências se deslocaram para as interações entre o nível federal e os sistemas municipais de saúde. Nesse âmbito, o Subsistema de Saúde Indígena passou a ocupar um lugar central na polaridade federalismo-descentralização, ainda que esse binômio não tivesse, no campo específico do indigenismo sanitário, o mesmo significado que assumiu no âmbito mais geral da Reforma Sanitária.

O período que antecede a promulgação da Lei Arouca pode ser entendido como algo próximo ao que Kingdon (1984) chama de situação de oportunidade, isto é, um momento inicial na construção de uma política pública, em que o tema emerge como prioritário, num amplo conjunto de decisões a serem tomadas pelo gestor público. No caso da saúde indígena, é o primeiro momento em que ocorre a atuação do Ministério de Saúde pós-Reforma Sanitária, operando como agente político prioritário, num cenário até então monopolizado pela política indigenista conduzida pela Funai, que não tinha afinidade com os rumos gerais da política de saúde instituída no país nem tinha delineado uma política específica para a saúde no leque de suas atividades. A entrada do Ministério da Saúde na cena social promoveu uma alteração significativa no modelo e práticas sanitários dirigidos a esses povos, imprimindo uma nova e irreversível dinâmica nas proposições instituídas nesse campo.

No período, o Ministério Público exerceu importante papel de monitoramento da atuação das instituições que disputavam a hegemonia no cenário da saúde indígena. O órgão produziu pareceres jurídicos e outros posicionamentos públicos, em particular do Ministério Público, que contribuíram para evitar que o Ministério da Saúde se eximisse das responsabilidades com a saúde indígena, uma vez que certos níveis de gestão do órgão relutavam em manter a saúde indígena no escopo de atuação da Funasa (Dodge, 2001).

Se o decreto $n$. 23/1990 pode ser entendido como um momento inicial de mudança na configuração dos atores-chave na política de saúde indígena, as disputas institucionais persistiram por cerca de oito anos, sem que se superasse 
o plano político discursivo na gestão da saúde indígena e sem que suas ações fossem concretamente operacionalizadas nas aldeias. Somente após a promulgação da Lei Arouca, a nova política tomou forma e ocupou algum espaço na agenda da política da saúde (Garnelo, 2006). Essa lei demarca o momento em que a questão da saúde indígena passa, segundo os termos de Kingdon (1984), da agenda sistêmica para a agenda governamental, ou seja, para o espaço de gestão em que um problema é incluído na lista de temas priorizados pelo poder público. Porém, os passos necessários à sua inclusão na agenda decisória do governo, ou seja, na lista de problemas a serem efetivamente enfrentados pelas autoridades do governo, têm sido lentos.

O início da operacionalização do Subsistema de Saúde Indígena ocorreu no governo FHC. ${ }^{16} \mathrm{Na}$ ocasião estava em curso uma reforma administrativa, que ficou conhecida como Reforma Bresser, que tinha entre seus desígnios a redução do papel do Estado. Daí derivava uma recusa implícita à proposta de universalização do SUS, a qual deveria ser substituída por uma cesta básica de serviços de saúde voltada para os estratos sociais mais vulneráveis.

Altos escalões do governo e o próprio presidente FHC tornaram pública a ideia de um redirecionamento das ações do SUS para os grupos mais desfavorecidos da sociedade, revertendo um dos pilares da Reforma Sanitária - que era a provisão da cobertura, pelo poder público, de todos os problemas de saúde, para todos os brasileiros. O caso indígena parecia ofertar alguns requisitos almejados pelo governo para testar a estratégia de focalização. A conjuntura específica da Reforma Bresser mostrou-se terreno favorável à escolha de rumos pelos quais o subsistema foi implantado: mediante a terceirização de suas ações para entidades de direito privado (ONGs), contratadas em regime de convênio para executar ações de interesse público. ${ }^{17}$

Essa alternativa era uma das que o movimento sanitário havia repudiado com vigor, em anos anteriores, para o SUS como um todo. Além da insistência na contratação de quadros próprios vinculados ao poder público, a descentralização havia-se aprofundado e propiciado o aprimoramento dos mecanismos de transferência de recursos do governo central para os municípios por meio dos fundos municipais de saúde (Ivo, 2004). No SUS, a nova forma de interação entre os níveis de governo propiciou o abandono da celebração de convênios, em favor de repasses diretos de recursos federais para as municipalidades. Tal modalidade de transferência de recursos viabilizava o recebimento regular de verbas, mediante pactuação trienal de metas e atividades, dos recursos advindos do Ministério da Saúde sem necessidade de enfrentar a trabalhosa burocracia dos convênios. O chamado repasse fundo a fundo permitiu manter a regularidade e a agilidade no custeio, propiciando continuidade das ações ao longo de todo o ano fiscal, o que tem impacto positivo sobre a efetividade do sistema. 
No caso da saúde indígena essa modalidade de repasse não poderia ser adotada, pois as conveniadas, sendo entidades de direito privado, não eram aptas a se habilitar à transferência fundo a fundo, que só pode ocorrer entre instituições públicas. A partir de 2003, aprofundou-se um sistema misto de repasse de recursos para a execução de ações de assistência aos indígenas, que a rigor já havia sido instituído em 1999, por meio da portaria n. 1.163: foi mantido o sistema de convênios firmados com entidades de direito privado e ampliou-se a transferência de recursos - oriundos da SAS do Ministério da Saúde -, via fundo municipal de saúde, para os municípios com população indígena em suas áreas de cobertura. Também foram firmados convênios com sistemas municipais de saúde, para efetuar contratação de pessoal para atuar no subsistema. Ou seja, duplicou-se a forma de pactuação, firmada tanto entre os entes federativos (governo federal e municípios) quanto com as ONGs, ampliando-se, consequentemente, a burocratização da gestão administrativa e financeira das ações do subsistema.

Nessas circunstâncias, a adoção da estratégia do convênio pode ser entendida como um retrocesso administrativo nas relações entre os níveis de governo, sendo, em grande medida, responsável pela descontinuidade das atividades nos DSEIs ao longo dos anos subsequentes à sua implantação. Por sua vez, os recursos repassados diretamente pela SAS aos fundos municipais de saúde foram alvo de denúncias recorrentes das lideranças indígenas, que alegavam que tais verbas eram utilizadas para outros fins e que não alcançavam os usuários indígenas a quem se destinavam.

Um capítulo específico nesse cenário foram os convênios firmados com as organizações indígenas. Estes ocorreram principalmente na Amazônia, onde o movimento indígena contava com instituições suficientemente estruturadas para efetuar a gestão de recursos públicos. Porém, o repasse súbito de pesadas responsabilidades para essas entidades, despreparadas técnica e administrativamente para assumi-las, comprometeu tanto a qualidade e a efetividade das ações de saúde quanto seu desempenho político, uma vez que sua finalidade primordial era a defesa dos direitos à diferença étnica e não a prestação de cuidados de saúde. Os custos políticos do fracasso dos convênios firmados entre a Funasa e as entidades indígenas é algo que ainda carece de uma avaliação detalhada, mas o prejuízo foi perceptível e redundou na desmobilização e mesmo encerramento das atividades de várias dessas entidades (Garnelo G Sampaio, 2003, 2005).

Em suma, o Subsistema de Saúde Indígena se instalou tardiamente num SUS que já tinha avançado por quase duas décadas rumo à municipalização, instituiu uma política dirigida às minorias num contexto político de luta contra a focalização da política de saúde e adotou estratégias administrativo-financeiras, como a celebração de convênios, que o movimento sanitário já havia repudiado e superado. 
Pelas razões expostas, entendemos que a vinculação da saúde indígena à Funasa obstaculizou o processo de gestão político-institucional, com repercussões negativas também no modelo assistencial do subsistema. Ainda que tenha adotado o rótulo da distritalização sanitária, a instituição manteve suas normatizações num amplo grau de generalidade, não detalhando suas concepções e práticas de atenção diferenciada, ou de distrito sanitário. Os atributos específicos desses dois elementos do modelo assistencial nunca foram devidamente explicitados; a Funasa também não definiu adequadamente os níveis de resolutividade das unidades assistenciais dos DSEIs nem emitiu protocolos técnicos que orientassem a atuação distrital e que explicitassem as especificidades necessárias à atuação de serviços de saúde em culturas indígenas - as quais, de resto, não diferem apenas de nossa sociedade, mas são também distintas entre si, demandando diferenciações ainda maiores nos modos de atuação das equipes de saúde, o que não ocorreu.

\section{Balanço Final}

Mais de dez anos após sua implantação, o subsistema não parece ter sido adequadamente absorvido pela corrente principal do SUS, mantendo-se como algo à parte ou, como disseram alguns, como um "SUS paralelo". Uma das consequências mais importantes dessa condição foi uma crônica carência de meios técnicos para efetivar as ações previstas nos dispositivos legais que o criaram, em que pese o crescimento do orçamento destinado ao financiamento das ações. Dentre as principais carências do subsistema, destaca-se a falta de recursos humanos, o que explica, pelo menos em parte, a opção recorrente pela compra de serviços de terceiros, feita por meio da celebração de convênios, para viabilizar o atendimento nas aldeias.

A análise aqui empreendida permitiu entender, nos moldes propostos por Viana e Baptista (2008), a trajetória de uma aspiração social que logrou transformar-se em uma política incluída na agenda de decisões do governo. Permitiu também mapear os diferentes atores, organizações e forças sociais que exigiram soluções e formularam propostas visando à implantação da PNASPI, bem como algumas das variáveis externas que influenciaram o processo. Igualmente demonstrou como a Política de Saúde Indígena foi instrumentalizada por certos grupos políticos que instituíram estilos decisórios e modos de operacionalização da assistência em moldes muito distintos do que foi preconizado nas conferências de saúde indígena.

Para o período estudado, conclui-se que a Política de Saúde Indígena percorreu os estágios característicos do ciclo de uma política pública: entrou na agenda de prioridades do movimento sanitarista e das autoridades governamentais; 
foi formulada; houve a tomada de decisão que a regulamentou e a implementou; e até mesmo passou por um processo avaliativo, ainda que não se faça perceptível a incorporação dos produtos dessa avaliação pelos gestores. Apesar disso, o Subsistema de Saúde Indígena tem-se mantido numa condição periférica na agenda da Política Nacional de Saúde.

Nesse olhar retrospectivo sobre a trajetória do subsistema, vê-se que a politics, se entendida como as relações de poder entre os grupos que atuam na Política de Saúde Indígena, foi marcada pela dificuldade na obtenção de consensos entre os atores que exerciam poder e influência em tal campo. A fase inicial foi caracterizada por uma aliança preferencial com entidades consideradas externas ao sistema de saúde, tais como ONGs, entidades indígenas, Banco Mundial e outras, sob a forte influência das prioridades estabelecidas pelas pautas ambientalistas para a Amazônia. Coincidentemente, esse foi também o período de maior confluência e visibilidade e da atuação do gestor público nessa região, revelando uma congruência político-geográfica entre as prioridades do nível central, agências financiadoras internacionais e entidades da sociedade civil, mobilizadas em torno da preservação ambiental, da qual a questão indígena tornou-se um elemento indissociável.

A mobilização de agentes externos à política de saúde favoreceu a tomada de decisão de efetivar uma política de saúde para as populações indígenas no Brasil. Contudo, a baixa capacidade de interveniência desses agentes políticos nos níveis de gestão operacional do Ministério da Saúde dificultou a incorporação das ações de saúde indígena nos espaços maiores de deliberação do SUS. Além disso, a escolha da Funasa como órgão de operacionalização do subsistema agravou o distanciamento e a fraca incorporação da temática indígena nos planos de ação do poder público, perpetuou a baixa capacidade técnica do órgão para atender às necessidades dos grupos atendidos e manteve o modelo vertical, centralizador e autoritário que caracterizou a atuação da Funasa e dos órgãos que a geraram.

Se no governo FHC os agentes políticos externos tiveram relativa capacidade de interveniência nos rumos do Subsistema de Saúde Indígena, ao longo dos dois governos do presidente Lula essa orientação foi redirecionada para o interior da própria Funasa, intensificando o controle do nível central e das coordenações estaduais sobre rumos da PNASPI, mas sem alcançar avanços significativos na capacidade de operacionalização do subsistema e no aprofundamento das interfaces com os outros níveis de gestão e de execução do SUS, em que pese o expressivo crescimento do financiamento das ações de saúde indígena no período.

Ainda que a atuação da sociedade tenha logrado criar uma situação de oportunidade (Kingdon, 1984) que favoreceu a emergência da PNASPI e a instituiu como prioridade na agenda política dos dirigentes, a resposta do Estado se mostrou contraditória. Por um lado, as autoridades responderam positivamente a essa demanda alocando esforços jurídicos, políticos, técnicos e financeiros para a criação 
do Subsistema de Saúde Indígena; por outro, instituíram uma operacionalização que se mostrou perversa, desperdiçadora de recursos e pouco capaz de atender, de maneira ética e tecnicamente eficaz, às responsabilidades que lhes foram atribuídas para atuar em níveis de gestão e execução das ações de saúde nas aldeias, persistindo e ampliando os vários níveis de clivagem entre os principais atores políticos que intervêm nesse cenário.

\section{Notas}

1 Este capítulo foi produzido originalmente no âmbito do Projeto Saúde e Condições de Vida de Povos Indígenas na Amazônia, Programa de Apoio a Núcleos de Excelência - Pronex/Fapeam/ CNPq, edital 003/2009.

2 Fleury e Ouverney (2008: 37-38) conceituam política social como um "conjunto de ações que objetivam a promoção da igualdade e do bem-estar, enfatizando assim os valores que guiam tais ações (...). As ações permanentes ou temporárias relacionadas ao desenvolvimento, à reprodução e à transformação dos sistemas de proteção social consistem no que chamamos de política social (...) [e] envolvem o desenvolvimento de estratégias coletivas para reduzir a vulnerabilidade das pessoas aos riscos sociais". No caso específico das políticas de saúde, as autoras ressaltam que suas características mais difundidas são o caráter setorial, sua organização em acordo com normas legalmente construídas e o compromisso maior com a qualidade de vida da população. A esse respeito, ver também Souza (2006) e Frey (2000).

3 O órgão recebeu inicialmente a sigla FNS, que depois foi modificada para Funasa. Usaremos aqui prioritariamente a sigla Funasa.

4 Oliveira Filho (1999a, 1999b) tem abordado o tema da dinâmica das identidades étnicas e os limites éticos e técnicos das instituições na lide com elas. Em publicação de 2000, o autor analisa especificamente as dificuldades de técnicos do Banco Mundial (BM) em encontrar (ou produzir?) características funcionais ou morfológicas passíveis de aplicação a todos os grupos indígenas no Brasil, de modo a identificar beneficiários (ou prejudicados) das intervenções do BM. Boa parte da argumentação do autor nessa publicação gira em torno da análise da inadequação e da pouca factibilidade de tal empreitada (Oliveira Filho, 2000).

5 Sobre o conceito de descentralização e a trajetória seguida por essa estratégia de gestão no SUS, ver também Tobar (1991), Silva (1996), Costa (2001), Barreto Jr. e Silva (2004), Ugá e colaboradores (2003), Souza (2006), Lima e Maio (2010); Viana e colaboradores (2002), Viana, Lima e Oliveira (2002), Vieira (2008).

6 O conceito de terceirização aqui adotado se refere ao processo político-administrativo de transferência total ou parcial das atribuições essenciais do Estado para a esfera privada (Fernandes, 1994).

7 Para uma crítica à noção de vulnerabilidade utilizada pelo Banco Mundial, ver Oliveira Filho (2000). 
8 Distritos Sanitários Especiais Indígenas (DSEIs) são sistemas locais de saúde encarregados de prover atenção à saúde dos povos indígenas que vivem em suas respectivas áreas de abrangência.

9 Em seu estudo, Baptista (2007) agrupou as portarias do Ministério da Saúde em quatro grandes eixos temáticos: 1) Gestão e organização do sistema e da assistência à saúde; 2) Financiamento; 3) Programas e ações verticais em saúde; 4) Outras. Todos os eixos congregavam temas mais específicos contidos nos textos das portarias. Aqui nos limitaremos a citar os temas do eixo "Gestão e organização do sistema e da assistência à saúde", por ser o de maior interesse para a análise da PNASPI. Na categorização de Baptista, esse eixo agrupa os seguintes temas: 1) regulamentação do sistema: normas operacionais, estratégias para a descentralização, planejamento e funcionamento de comissões, regras para o controle e avaliação do sistema; 2) organização da estrutura: mudanças na estrutura do Ministério da Saúde, cargos, funções e secretarias; 3) regulamentação de rotinas: organização dos fluxos e práticas gerenciais do sistema; 4) habilitações: municípios e estados habilitados conforme as regras das normas operacionais e condições de gestão propostas; 5) licitações e cadastro: autorização, credenciamento ou descredenciamento para o funcionamento de unidades e serviços de saúde.

10 O decreto n. 4.727/2003 foi revogado pelo decreto n. 7.335/2010, que regulamentou as novas atribuições da Funasa após o remanejamento da saúde indígena para a Sesai.

11 Notas de protesto e denúncias na imprensa foram dispostas, na época, nas páginas da web dessas instituições, disponíveis nos endereços: <www.socioambiental.org> (acesso em: 13 maio 2011); <www.cimi.org.br> (acesso em: 13 maio 2011); <www.foirn.org.br> (acesso em: 23 jun. 2011) e <www.coiab.com.br> (acesso em: 23 jun. 2011).

12 A recém-criada instituição recebeu também as atividades das Secretarias Nacionais de Ações Básicas de Saúde (SNABS) e de Programas Especiais de Saúde (SNPES), ambas do Ministério da Saúde e da Empresa de Processamento de Dados da Previdência Social (Dataprev).

13 Tanto a Fundação Sesp quanto a Sucam, bem como as ações sob sua responsabilidade, foram objeto de diversas publicações, que correlacionaram políticas gerais de saúde pública com a atuação da Fundação Sesp (caso das políticas de saneamento) e da Sucam (caso das ações de controle de endemias rurais), ou a trajetória e operacionalização de ambas as instituições. Para mais informações, ver Silva (2003), Varga (2007), Campos (2006), Castro-Santos, 1985), Hochman (1998), Moraes (2000), Lima e Maio (2010).

14 A esse respeito, ver Teixeira (2008).

15 O relatório de auditoria do TCU (Brasil, 2007) mostra que, ao contrário da alegada carência de pessoal, a Funasa tinha, no nível central, um grande número de servidores cedidos - e não redistribuídos - para outros órgãos, o que onerava seu orçamento e não contribuía para melhorar seu desempenho. O TCU aponta também redundância no organograma e no regimento do órgão, de setores e funções gratificadas, referentes a atribuições já repassadas, há vários anos, a outros órgãos do SUS, configurando a persistência do paralelismo da atuação da Funasa com outras instâncias do SUS.

16 É extensa a literatura que analisa as políticas sociais do governo FHC e suas implicações no SUS, assumindo posições favoráveis e contrárias a elas. Assinalamos como importante para 
esta análise Bresser Pereira (1998), Gerschman (1999), Barbosa e Elias (2010), Cohn (2000), Cordeiro (2001), Levcovitz, Lima e Machado (2001), Draibe (2003), Viana, Fausto e Lima (2003), Ivo (2004), Barreto Jr. e Silva (2004), Machado, Baptista e Lima (2010). Já Hoffman e colaboradores (2004) tratam especificamente da política indigenista na era FHC.

17 Sobre a interação entre o poder público e o Terceiro Setor, ver Fernandes (1994), Falcão Martins (1998) e Lopes (2004).

\section{Referências}

AITH, F. Saúde indígena no Brasil: atual quadro jurídico-administrativo do Estado brasileiro e desafios para a garantia do direito à saúde da população indígena. Revista de Direito Sanitário, 9(3): 115-132, 2009.

APPOLINÁRIO, F. Dicionário de Metodologia Científica: um guia para a produção do conhecimento científico. São Paulo: Atlas, 2009.

ARRETCHE, M. Financiamento federal e gestão local de políticas sociais: o difícil equilíbrio entre regulação, responsabilidade e autonomia. Ciência G Saúde Coletiva, 8(2): 331-345, 2003.

ARRETCHE, M. A política da política de saúde no Brasil. In: LIMA, N. T.; GERSHMAN, S. G EDLER, F. C. (Orgs.). Saúde e Democracia: história e perspectivas do SUS. Rio de Janeiro: Editora Fiocruz, 2005.

ARRETCHE, M. G VASQUEZ, D. A. Descentralização, instituições políticas e autonomia: padrões de gasto dos governos locais no Brasil. In: CONGRESS OF THE LATIN AMERICAN STUDIES ASSOCIATION, I, 2009, Rio de Janeiro. Anais... Rio de Janeiro, 2009. Disponível em: < http://lasa.international.pitt.edu/members/congress-apers/lasa2009/ files/ArretcheMarta.pdf>. Acesso em: 6 mar. 2012.

ATHIAS, R. G MACHADO, M. A saúde indígena no processo de implementação dos distritos sanitários: temas críticos e propostas para um diálogo interdisciplinar. Cadernos de Saúde Pública, 17(2): 425-431, 2001.

BAPTISTA, T. W. F. Análise das portarias ministeriais da saúde e reflexões sobre a condução nacional da política de saúde. Cadernos de Saúde Pública, 23(3): 615-626, 2007.

BARBOSA, N. B. G ELIAS, P. E. M. As organizações sociais de saúde como forma de gestão público/privado. Ciência G Saúde Coletiva, 15(5): 2.483-2.495, 2010.

BARDIN, L. Análise de Conteúdo. Lisboa: Edições 70, 1979.

BARRETO JR., I. F. B. G SILVA, Z. R. Reforma do sistema de saúde e as novas atribuições do gestor estadual. São Paulo em Perspectiva, 18(3): 47-56, 2004.

BOURDIEU, P. A Economia das Trocas Linguísticas. São Paulo: Edusp, 1996. 
BRASIL. Tribunal de Contas da União. Secretaria de Fiscalização e Avaliação de Programas de Governo Relatório de Auditoria na Fundação Nacional de Saúde. Relatório de Auditoria de Natureza Operacional Fundação Nacional da Saúde - Funasa, 2007. Disponível em: < http://portal2.tcu.gov.br/portal/page/portal/TCU/comunidades/programas_governo/ areas_atuacao/saude/Relat\%C3\%B3rio\%20de\%20Auditoria_0.pdf $>$. Acesso em: 30 out. 2011.

BRASIL. Ministério da Saúde. Funasa. Site. Disponível em: <www.funasa.gov.br>. Acesso em: 10 jun. 2014.

BRESSER PEREIRA, L. C. A reforma do Estado dos anos 90: lógica e mecanismos de controle. Lua Nova, 45: 49-95, 1998.

CAMPOS, A. L. V. Políticas Internacionais de Saúde na Era Vargas: o Serviço Especial de Saúde Pública, 1942-1960. Rio de Janeiro: Editora Fiocruz, 2006. (Coleção História e Saúde).

CARVALHO, G. A inconstitucional administração pós-constitucional do SUS através de normas operacionais. Ciência G Saúde Coletiva, 6: 2: 435-444, 2001.

CASTRO-SANTOS, L. A. O pensamento sanitarista na Primeira República: uma ideologia de construção da nacionalidade. Dados - Revista de Ciências Sociais, 28(2): 237-250, 1985.

CELLARD, A. A análise documental. In: POUPART, J. et al. (Orgs.). A Pesquisa Qualitativa: enfoques epistemológicos e metodológicos. Petrópolis: Vozes, 2008.

CHAVES, M. B. G.; CARDOSO, A. M. G ALMEIDA, C. Implementação da Política de Saúde Indígena no Polo-Base Angra dos Reis, Rio de Janeiro, Brasil: entraves e perspectivas. Cadernos de Saúde Pública, 22(2): 295-305, 2006.

COHN, A. As políticas sociais no governo FHC. Tempo Social, 11(2): 183-197, 2000.

COHN, A. O SUS e o direito à saúde: universalização e focalização nas políticas de saúde. In: LIMA, N. T.; GERSHMAN, S. G EDLER, F. C. (Orgs.). Saúde e Democracia: história e perspectivas do SUS. Rio de Janeiro: Editora Fiocruz, 2005.

COMISSÃO PRÓ-YANOMAMI (CCPY). Saúde Indígena: impasse no modelo de gestão - a saga das reformas na saúde indígena (1967-1999). Disponível em: <www.socioambiental.org/ banco_imagens/pdfs/ccpy.pdf>. Acesso em: 20 maio 2011.

CONFALONIERI, U. et al. Amazon Health Report. Diagnóstico sanitário de populações indígenas da Amazônia, patrocinado pelo Banco Mundial e pelo Royal Tropical Institute (Amsterdã), 1993.

CORDEIRO, H. Descentralização, universalidade e equidade nas reformas da saúde. Ciência G Saúde Coletiva, 6(2): 319-328, 2001.

CORTES, S. V. Sistema Único de Saúde: espaços decisórios e a arena política de saúde. Cadernos de Saúde Pública, 25(7): 1.626-1.633, 2009.

COSTA, D. C. Política indigenista e assistência à saúde: Noel Nutels e o Serviço de Unidades Sanitárias Aéreas. Cadernos de Saúde Pública, 4(3): 388-340, 1987. 
COSTA, N. R. A descentralização do sistema público de saúde no Brasil: balanço e perspectiva. In: NEGRI, B. G GIOVANNI, G. (Orgs.). Brasil: radiografia da saúde. Campinas: Unicamp, 2001.

COSTA, N. R. A proteção social no Brasil: universalismo e focalização nos governos FHC e Lula. Ciência G Saúde Coletiva, 14(3): 693-706, 2009.

DAVIS, S. H. The World Bank and Indigenous People. Denver Initiative Conference on Human Rights, University of Denver Law School, Denver, Colorado, April 16-17, 1993. Disponível em: <www-wds.worldbank.org/servlet/WDSContentServer/WDSP/IB/2003/11/14/00001 2009_20031114144132/Rendered/PDF/272050WB0andOIndigenousOPeoples01 public1. pdf >. Acesso em: 20 ago. 2012.

DAVIS, S. H. G PARTRIDGE, W. Promoting the Development of Indigenous Peoples in Latin America. The World Bank, 1999. Disponível em: <http://siteresources.worldbank.org/ INTRANETSOCIALDEVELOPMENT/873351- 1111663716403/20600877/PromotingDevofIPinLAC.pdf>. Acesso em: 19 fev. 2011.

DINIZ, E. Em busca de um novo paradigma: a reforma do Estado no Brasil dos anos 90. São Paulo em Perspectiva, 10(4): 13-26, 1996.

DODGE, R. E. F. Saúde indígena. Boletim dos Procuradores da República, 2: 21-24, 1998.

DODGE, R. E. F. Povos indígenas: direito, ética e controle social. Boletim dos Procuradores da República, 38: 14-18, 2001.

DRAIBE, S. A política social no governo FHC e o Sistema de Proteção Social. Tempo Social USP, 15(2): 63-101, 2003.

DRUCK, G. G FILGUEIRAS, L. Política social focalizada e ajuste fiscal: as duas faces do governo Lula. Lusotopie, 14(2): 133-146, 2007.

FALCÃO MARTINS, H. Em busca de uma teoria da burocracia pública não estatal: política e administração no Terceiro Setor. Revista de Administração Contemporânea, 2(3): 109$128,1998$.

FERNANDES, R. Privado Porém Público: o Terceiro Setor na América Latina. Rio de Janeiro: Relume Dumará, 1994.

FLEURY, S. G OUVERNEY, A. Política de saúde: uma política social. In: GIOVANELLA, L. et al. (Orgs.). Políticas e Sistema de Saúde no Brasil. Rio de Janeiro: Editora Fiocruz, 2008.

FREY, K. Políticas públicas: um debate conceitual e reflexões referentes à prática das políticas públicas no Brasil. Planejamento e Políticas Públicas, 21: 211-259, 2000.

GARNELO, L. Análise situacional da Política de Saúde dos Povos Indígenas no período de 1990 a 2004: implicações no Brasil e na Amazônia. In: SCHERER, E. G OLIVEIRA, J. A. (Orgs.). Amazônia: políticas públicas e diversidade cultural. Rio de Janeiro: Garamond, 2006.

GARNELO, L. G ESCOBAR, A. L. Compasso e descompasso da Política de Saúde Indígena no Brasil contemporâneo: rumamos para a municipalização? In: REUNIÃO DE ANTROPOLOGIA 
DO MERCOSUL. MRO3 - POLÍTICAS PÚBLICAS EM SAÚDE E DIREITOS ÉTNICOS NA AMÉRICA DO SUL TRABALHO, VII, 2007, Porto Alegre. Anais... Porto Alegre, 2007.

GARNELO, L. G SAMPAIO, S. Bases socioculturais do controle social em saúde indígena. Cadernos de Saúde Pública, 19(1): 311-318, 2003.

GARNELO, L. G SAMPAIO, S. Organizações indígenas e distritalização sanitária: os riscos de fazer ver e fazer crer nas políticas de saúde. Cadernos de Saúde Pública, 21(4): 1.217$1.223,2005$.

GARNELO, L.; MACEDO, G. G BRANDÃO, L. C. Os Povos Indígenas e a Construção das Políticas Públicas no Brasil. Brasília: Opas, 2003.

GERSCHMAN, S. S. Las reformas del Estado, de las políticas sociales y de salud: un balance del final del milenio. Cadernos de Saúde Pública, 15(2): 293-302, 1999.

HOCHMAN, G. A Era do Saneamento: as bases da política de saúde pública no Brasil. São Paulo: Hucitec, Anpocs, 1998.

HOFFMANN, M. B. et al. Administração pública e os povos indígenas. In: ROCHA, D. G BERNARDO, M. (Orgs.). A Era FHC e o Governo Lula: transição? Brasília: Inesc, 2004.

IVO, A. B. L. A reconversão do social: dilemas da redistribuição no tratamento focalizado. São Paulo em Perspectiva, 18(2): 57-67, 2004.

JOBERT, B. G MULLER, P. L'État en Action. Paris: PUF, 1987.

KINGDON, J. Agendas, Alternatives and Public Policies. Boston: Little, 1984.

LANGDON, E. J. Diversidade cultural e os desafios da Política Brasileira de Saúde do Índio. Saúde e Sociedade, 16: 7-12, 2007.

LANGDON, E. J. G DIEHL, E. Participação e autonomia nos espaços interculturais de saúde indígena: reflexões a partir do Sul do Brasil. Saúde e Sociedade, 16: 19-36, 2007.

LEVCOVITZ, E.; LIMA, L. D. G MACHADO, C. V. Política de saúde nos anos 90: relações intergovernamentais e papel das normas operacionais básicas. Ciência G Saúde Coletiva, 6(2): 269-291, 2001.

LIMA, N. T. G MAIO, M. C. Ciências sociais e educação sanitária: a perspectiva da Seção de Pesquisa Social do Serviço Especial de Saúde Pública na década de 1950. História, Ciência, Saúde - Manguinhos, 17(2): 511-526, 2010.

LOPES, J. R. Terceiro Setor: a organização das políticas sociais e a nova esfera pública. São Paulo em Perspectiva, 18(3): 57-66, 2004.

MACHADO, C. V.; BAPTISTA, T. W. F. G LIMA, L. D. O planejamento nacional da política de saúde no Brasil: estratégias e instrumentos nos anos 2000. Ciência G Saúde Coletiva, 15(5): 2.367-2.382, 2010.

MARQUES, R. M. G MENDES, A. O governo Lula e a contrarreforma previdenciária. São Paulo Perspectiva, 18(3): 3-15, 2004. 
MARQUES, R. M. G MENDES, A. Servindo a dois senhores: as políticas sociais no governo Lula. Revista Katálysis, 10(1): 15-23, 2007.

MORAES, H. F. Sucam: sua origem, sua história. Brasília: Ministério da Saúde, 2000.

MULLER, P. Les Politiques Publiques. Paris: PUF, 1990.

OLIVEIRA FILHO, J. P. Ensaios em Antropologia Histórica. Rio de Janeiro: Editora UFRJ, 1999a.

OLIVEIRA FILHO, J. P. (Org.) A Viagem da Volta: etnicidade, política e reelaboração cultural no Nordeste indígena. Rio de Janeiro: Contra Capa, 1999b.

OLIVEIRA FILHO, J. P. Cidadania e globalização: povos indígenas e agências multilaterais. Horizontes Antropológicos, 6(14): 125-141, 2000.

PASCHE, D. F. et al. Paradoxos das políticas de descentralização de saúde no Brasil. Revista Panamericana de Salud Pública, 20(6): 416-422, 2006.

PONTES, A. L. G GARNELO, L. A construção do modelo de atenção diferenciada para a saúde indígena no Brasil e a integralidade. In: PINHEIRO, R. G SILVA JR., A. G. (Orgs.) Por uma Sociedade Cuidadora. Rio de Janeiro: Cepesc, IMS/Uerj, 2010.

RAGGIO, A.; PINTO, N. P. G MORAES, P. Análise da gestão. In: ASSOCIAÇÃO SAÚDE SEM LIMITES (SSL); INSTITUTE OF DEVELOPMENT STUDIES (IDS) G CENTRO BRASILEIRO DE ANÁLISE E PLANEJAMENTO (CEBRAP). Consultoria para Definição e Implementação de Metas e Modelos de Atenção, Organização, Gestão, Financiamento e Monitoramento G Avaliação do Subsistema de Saúde Indígena: 2008/2009, 2008. CD-ROM.

SANTOS, R. V. et al. Saúde dos povos indígenas e políticas públicas no Brasil. In: GIOVANELLA, L. et al. (Orgs.). Políticas e Sistema de Saúde no Brasil. Rio de Janeiro: Editora Fiocruz, 2008.

SILVA, L. J. O controle das endemias no Brasil e sua história. Ciência e Cultura, 55(1): 44-47, 2003.

SILVA, Z. P. O município e a descentralização da saúde. São Paulo em Perspectiva, 10(3): 81-87, 1996.

SOUZA, C. Políticas públicas: uma revisão da literatura. Sociologias, 8(16): 20-45, 2006.

SOUZA LIMA, A. C. Sobre indigenismo, autoritarismo e nacionalidade: considerações sobre a constituição do discurso e da prática da proteção fraternal no Brasil. In: OLIVEIRA, J. P. (Org.). Sociedades Indígenas e Indigenismo no Brasil. Rio de Janeiro, São Paulo: Ed. UFRJ, Marco Zero, 1987.

SOUZA LIMA, A. C. Um Grande Cerco de Paz: poder tutelar, indianidade e formação do Estado no Brasil. Petrópolis: Vozes, 1995.

TEIXEIRA, C. C. Fundação Nacional de Saúde: a política brasileira de saúde indígena vista através de um museu. Etnográfica, 12(2): 323-351, 2008. 
TOBAR, F. O conceito de descentralização: usos e abusos. Planejamento e Políticas Públicas, 5: 31-51, 1991.

UGÁ, M. A. et al. Descentralização e alocação de recursos no âmbito do Sistema Único de Saúde (SUS). Ciência G Saúde Coletiva, 8(2): 417-437, 2003.

VARGA, I. D. Indigenismo sanitário? Instituições, discursos e políticas indígenas no Brasil contemporâneo. Cadernos de Campo (USP), 2(2): 132-142, 1992.

VARGA, I. D. Fronteiras da urbanidade sanitária: sobre o controle da malária. Saúde e Sociedade, 6(1): 28-44, 2007.

VARGA, I. D. Secretaria Especial de Atenção à Saúde Indígena: desafios. BIS - Boletim do Instituto de Saúde, 129(2): 167-171, 2010.

VARGA, I. D. G ADORNO, R. C. F. Terceirizando a indianidade? Sobre a Política Nacional de Saúde para os Povos Indígenas, aos '500 anos'. Revista de Direito Sanitário, 2(1): 9-26, 2001.

VARGA, I. D. G VIANA, R. L. Distrito Sanitário Especial Indígena do Maranhão: crônicas de um desastre anunciado. Revista de Direito Sanitário, 9(3): 133-149, 2009.

VERDUM, R. Avanços e retrocessos da política indigenista. Boletim Orçamento G Políticas Socioambientais, 12: 1-12, 2005.

VERDUM, R. Orçamento de Ação Indigenista do Governo Federal em 2008. Inesc Nota Técnica, n. 148, 2009a. Disponível em: <www.inesc.org.br/biblioteca/publicacoes/ notas-tecnicas/nts-anteriores/nts-2009/NT.\%20148\%20-\%200\%20orcamento\%20da\%20 acao\%20indigenista\%20do\%20governo\%20federal\%20em\%202008.pdf/view>. Acesso em: 20 jun. 2011.

VERDUM, R. El indigenismo brasileño en tiempos de multiculturalismo. Alteridades, 18(35): 33-46, 2009b.

VERDUM, R. Povos Indígenas no Brasil: o desafio da autonomia. In: VERDUM, R. (Org.). Povos Indígenas: constituições e reformas políticas na América Latina. Brasília: Instituto de Estudos Socioeconômicos, 2009c.

VERDUM, R. Orçamento Indigenista da União no PPA 2008-2011, s.d. Disponível em: <www.cimi.org.br/pub/publicacoes/1222438549_orcamento\%20ppa.pdf > . Acesso em: 20 jun. 2011.

VIANA, A. L. D. G BAPTISTA, T. W. Análise de políticas de saúde. In: GIOVANELLA, L. et al. (Orgs.). Políticas e Sistema de Saúde no Brasil. Rio de Janeiro: Editora Fiocruz, 2008.

VIANA, A. L. D.; FAUSTO, M. C.R. G LIMA, L. D. Política de saúde e equidade. São Paulo em Perspectiva, 17(1): 58-68, 2003.

VIANA, A. L. D.; LIMA, L. D. G OLIVEIRA, R. G. Descentralização e federalismo: a política de saúde em novo contexto - lições do caso brasileiro. Ciência G Saúde Coletiva, 7(3): 493-507, 2002. 
VIANA, A. L. D. et al. Mudanças significativas no processo de descentralização do sistema de saúde no Brasil. Cadernos de Saúde Pública, 18(supl.): 139-151, 2002.

VIEIRA, F. S. Descentralização da política de saúde no Brasil: avanços e desafios. Revista de Políticas Públicas e Gestão Governamental, 7(2): 27-42, 2008. 
O Subsistema de Saúde Indígena em Ação 


\section{Do Museu aos Manuais: reflexões sobre o agente indígena de saneamento ${ }^{1}$}

As indagações que sustentam este capítulo remontam a dois momentos distintos de minha trajetória de pesquisa. O primeiro momento refere-se à contribuição para o desenvolvimento de uma metodologia multidisciplinar adequada à avaliação do impacto das ações de saneamento nas condições de saúde (20032004); ${ }^{2}$ o segundo tem início com a visita ao Museu da Fundação Nacional da Saúde (Funasa) em 2006. Ambas as experiências contribuíram articuladamente para que o agente indígena de saneamento (Aisan) se transformasse em foco de minhas investigações. A participação em uma equipe multidisciplinar, com significante presença de engenheiros do Departamento de Engenharia de Saúde Pública (Densp/ Funasa), revelou-me a importância deste setor na história da instituição e a articulação entre preocupações técnico-sanitárias e sociais que orientavam as reflexões desses engenheiros. Por sua vez, a incursão nas instalações do Museu da Funasa, com sua forma de organização dos objetos, suas prioridades e especificações, nas quais a história da saúde pública brasileira é equacionada com as campanhas de saúde pública, despertou-me o interesse nos antecedentes históricos da Funasa e como estes se articulavam com a forma como a instituição vinha desempenhando sua "missão" de promoção e proteção à saúde indígena.

A reduzida visibilidade construída para a Política de Saúde Indígena e o destaque atribuído à função do Guarda da Superintendência de Campanhas de Saúde Pública (Sucam) no museu constituem a conexão de sentido que as minhas reflexões sobre o Aisan, desenvolvidas com base no Manual do Agente Indígena de Saneamento, pretendem iluminar. Busco, portanto, compreender duas formas complementares de (re)produção de conhecimento entre os distintos profissionais que atuam na saúde indígena: os materiais formalmente produzidos pela instituição para a formação de seus quadros; e a organização da memória institucional, no caso aqui em foco, da fundação responsável pela gestão da Política de Saúde Indígena até 2010, a Funasa.

A pesquisa dos manuais do guarda sanitário escritos pelos engenheiros do Serviço Especial de Saúde Pública (Sesp) nos anos 1940 e pela Fundação do Serviço Especial de Saúde Pública (Fundação Sesp) nos anos 1970 foi, simultaneamente, o 
caminho percorrido para a compreensão do Manual do Agente Indígena de Saneamento publicado pela Funasa nos anos 2000 e o critério de relevância responsável por sua escolha como objeto de reflexão. Nesse sentido, a análise desse manual tem duplo objetivo: 1) rastrear suas conexões históricas, suas linhas de continuidade e mudança em relação aos manuais do Sesp e da Fundação Sesp - que, espero demonstrar ao leitor, inspiraram sua elaboração; e 2) compreender sua própria estrutura atual como um manual técnico inserido em um contexto político distinto e voltado para a formação de um trabalhador da saúde também diferenciado dos que o antecederam. Consiste, assim, numa investigação que se insere no universo de reflexão sobre as ações de políticas públicas, ou melhor, sobre a estrutura do Estado em ação, a burocracia em governança, reconhecendo a necessidade de remeter tal reflexão a temporalidades que transcendem os marcos da memória recente dos sujeitos (e de seus objetos) em ação, mas que nesta se expressam transversalmente.

Para atingir esses objetivos, inicialmente faço uma breve exploração do Museu da Funasa; em seguida apresento os manuais do Sesp e da Fundação Sesp para, então, abordar o Manual do Agente Indígena de Saneamento desenvolvido pela Funasa quando ainda era responsável pela saúde indígena. Ao longo desse percurso, algumas preocupações destacaram-se no recorte etnográfico-documental em um processo de mútua criação, ou seja, ao mesmo tempo que eram suscitadas pelo material em foco, orientavam o olhar interpretativo sobre este e, consequentemente, seu próprio recorte e construção: 1) as faces constitutivas de uma memória social $^{3}$ - no caso, a da saúde pública; 2) as vinculações entre eficácia técnica e eficácia social; e 3) a produção política da repulsa.

\section{O Museu da Funasa: um empreendimento de memória institucional ${ }^{4}$}

O Museu da Funasa é o único museu da saúde localizado em Brasília, compondo junto com outros museus institucionais (dos Correios, da Previdência Social, da Fazenda etc.) a grande maioria dos museus da cidade. É um museu pequeno constituído por um conjunto de três salas de acesso público e um subsolo, no qual são guardadas as peças que não se encontram disponíveis aos visitantes, além de cinco vitrines externas, uma ampla sala onde se encontra o acervo iconográfico, tendo à sua direita a passagem para a sala do acervo documental na qual existia uma pequena sala interativa - com a temática do mascote Zé Gotinha das campanhas de vacinação contra a paralisia infantil. 5

No acervo iconográfico, exposição principal do museu, observa-se o predomínio de imagens e objetos das campanhas de erradicação de endemias rurais que se encontram organizados por tipo de doença: malária, febre amarela, bócio, 
esquistossomose, doença de Chagas, peste, tracoma, poliomielite, cólera. Dentre tais objetos e imagens se destaca a presença de peças oriundas da extinta Sucam, que, em 1991, veio a formar a Funasa junto com a Fundação Sesp. A explicação institucional 6 desse predomínio é que o museu foi constituído a partir do Museu da Sucam, que funcionava no próprio prédio do Ministério da Saúde. Em 2002, este museu foi reformado sob as orientações de um grupo de trabalho constituído exclusivamente para essa finalidade, com a participação de especialistas da saúde pública e a consultoria de uma museóloga, e foi reinaugurado no local onde se encontra hoje. ${ }^{7}$ Contudo, sua origem não é suficiente para compreendermos a permanência dessa organização em um museu que se apresenta aos visitantes, em seu mural de abertura, como: "Em nova sede, e totalmente reformulado, coloca à disposição do público a história da saúde pública brasileira" (grifos meus). Ainda mais se considerarmos que cerca de três anos depois a única modificação observada na composição do acervo foi o deslocamento do reduzido conjunto de objetos relativos à saúde indígena para a última vitrine exterior, fora do alcance da visão dos visitantes ao chegarem, e sua substituição por peças da campanha de erradicação da poliomielite. Essa redução ocorreu apesar da declaração da coordenadora em 2006, que afirmou: "a gente precisa correr atrás de um acervo da saúde indígena", ', otimista com a portaria assinada em 2005 criando um Comitê do Patrimônio Cultural da Saúde (Ministério da Saúde e Instituto do Patrimônio Histórico e Artístico Nacional/Iphan, Ministério da Cultura). Não tive oportunidade de voltar a conversar com ela posteriormente para indagar sobre os desdobramentos efetivos dessa portaria. No entanto, tal deslocamento da saúde indígena para o exterior do museu acompanha e ao mesmo tempo é parte do movimento de retirada da gestão da saúde indígena da Funasa e sua transferência para uma secretaria diretamente vinculada ao Ministério da Saúde criada em 2010.8

Não pretendo aqui, pois já o fiz em outra oportunidade (Teixeira, 2008a), explorar as afinidades eletivas entre a organização do museu e a vocação e o lugar institucional da Funasa, mas é importante pontuar, para as reflexões que farei neste capítulo, que o processo histórico em que se dá sua criação articula-se a partir da implantação do Sistema Único de Saúde (SUS) nos anos 1990. Em meio ao processo de redemocratização brasileira, o SUS afirma a saúde como direito fundamental de cidadania e estabelece como seus princípios norteadores a universalidade com gratuidade, integralidade, participação e descentralização, retirando do âmbito federal a atribuição de execução das ações de saúde. Contudo, no curso histórico também surgem, para constituir a espinha dorsal da Funasa, duas instituições, a Sucam e a Fundação Sesp, expoentes do sucesso de uma concepção de gestão de saúde pública comprometida com a tradição campanhista, ou seja, com o

predomínio das intervenções públicas de saúde focalizadas em doenças endêmicas (malária, febre amarela, tuberculose, doença de chagas, dengue etc.), de natureza 
pontual (campanhas periódicas), centralizada em termos de concepção e controle da execução (na esfera federal) e autoritária (estrutura militarizada e com poder de polícia). (Teixeira, 2008a: 325)

Estabelecido esse horizonte interpretativo mais abrangente, ${ }^{9}$ a indagação que me orienta neste capítulo tem como fio condutor o lugar de destaque atribuído à representação do Guarda da Sucam, de modo a construir as conexões de sentido com a função similar na Fundação Sesp, o guarda sanitário, em mesmo período e sua versão contemporânea, ou seja, o Aisan. Trata-se, portanto, de um empreendimento que busca explorar o processo de memorização institucional como parte da produção de uma memória pública, da saúde pública e do lugar nesta atribuído à saúde indígena, em sua dupla direção temporal: em sua orientação para um passado a ser honrado e celebrado pelos que o viveram diretamente e também pelos que não lhe foram contemporâneos; bem como pelo que permite projetar para o que lhe sucede no presente e antecipar os possíveis caminhos de um porvir.

Ao chegar ao museu, o visitante é imediatamente introduzido no mundo das doenças, mas, sobretudo, ele é apresentado às formas de combate às doenças pelas peças selecionadas para recepcioná-lo (Figura 1). Já na entrada, encontra-se uma vitrine com um conjunto impressionante composto pelo uniforme e pela máscara "de proteção individual usados pelo Guarda no trabalho de aplicação de cianogás na Campanha contra a Peste". ${ }^{10}$ Mais adiante há em uma vitrine à esquerda do salão de exposição uma apresentação do Guarda da Sucam (Figura 2) ${ }^{11}$ em manequim de tamanho natural em proporções agigantadas (medindo cerca de dois metros de altura), devidamente caracterizado com uniforme e outros objetos. Somente após passar por essas peças, o visitante dá início à apreciação dos painéis fotográficos, instrumentos e espécimes relacionados a cada tipo de doença que compõe o acervo iconográfico do salão principal do museu. Apenas outro integrante das campanhas de saúde tem tal destaque: o atual Zé Gotinha da campanha de vacinação da poliomielite. Contudo, o personagem mascote não representa uma função na estrutura de execução dos serviços de saúde pública; seu lugar de destaque no museu celebra o sucesso da estratégia das campanhas de vacinação da poliomielite que lograram erradicar a doença no país em cerca de três décadas. ${ }^{12}$

Nessa perspectiva, urge refletir sobre o que estaria sendo celebrado por meio da apresentação do Guarda da Sucam, ou seja, de um personagem pertencente à configuração hierárquica autoritária da saúde pública, como se pode ler nas entrevistas a seguir:

Uma grande marca destes órgãos [Sucam e Fundação Sesp] era a questão da hierarquia e da disciplina. O nosso guarda [da Sucam] tinha o que a gente chamava de chave de apresentação. Por exemplo, na campanha de febre amarela, ele tinha o nome de guerra e tinha que dizer na sua apresentação à pessoa da casa: 
o nome, a patente e a atividade que estava fazendo. Por exemplo: José Machado, inspetor de endemias, número tal, fazendo um trabalho de combate ao mosquito transmissor da febre amarela na ação de operação de inseticida. Quando ele ia entrar na casa ele tinha que pedir licença e tinha um texto, ele tinha que passar uma mensagem padronizada. De Norte a Sul do país, em qualquer lugar a marca era padrão. (Funcionário da Funasa, ex-Sucam, 2006)

No programa da doença de Chagas, por exemplo, ele chegava e entrava no domicílio da pessoa, dava bom-dia e tudo mais, mas ele se apropriava daquele domínio particular que é o domicílio e fazia um auê na casa [em busca do barbeiro]. As pessoas recebiam de forma muito passiva (...), mas aqueles que não queriam fechavam sua casa e iam embora. Então isto se chamava recusa. (Funcionária da Funasa, ex-Sucam, 2006)

Figura 1 - Vitrine de entrada, Museu da Funasa

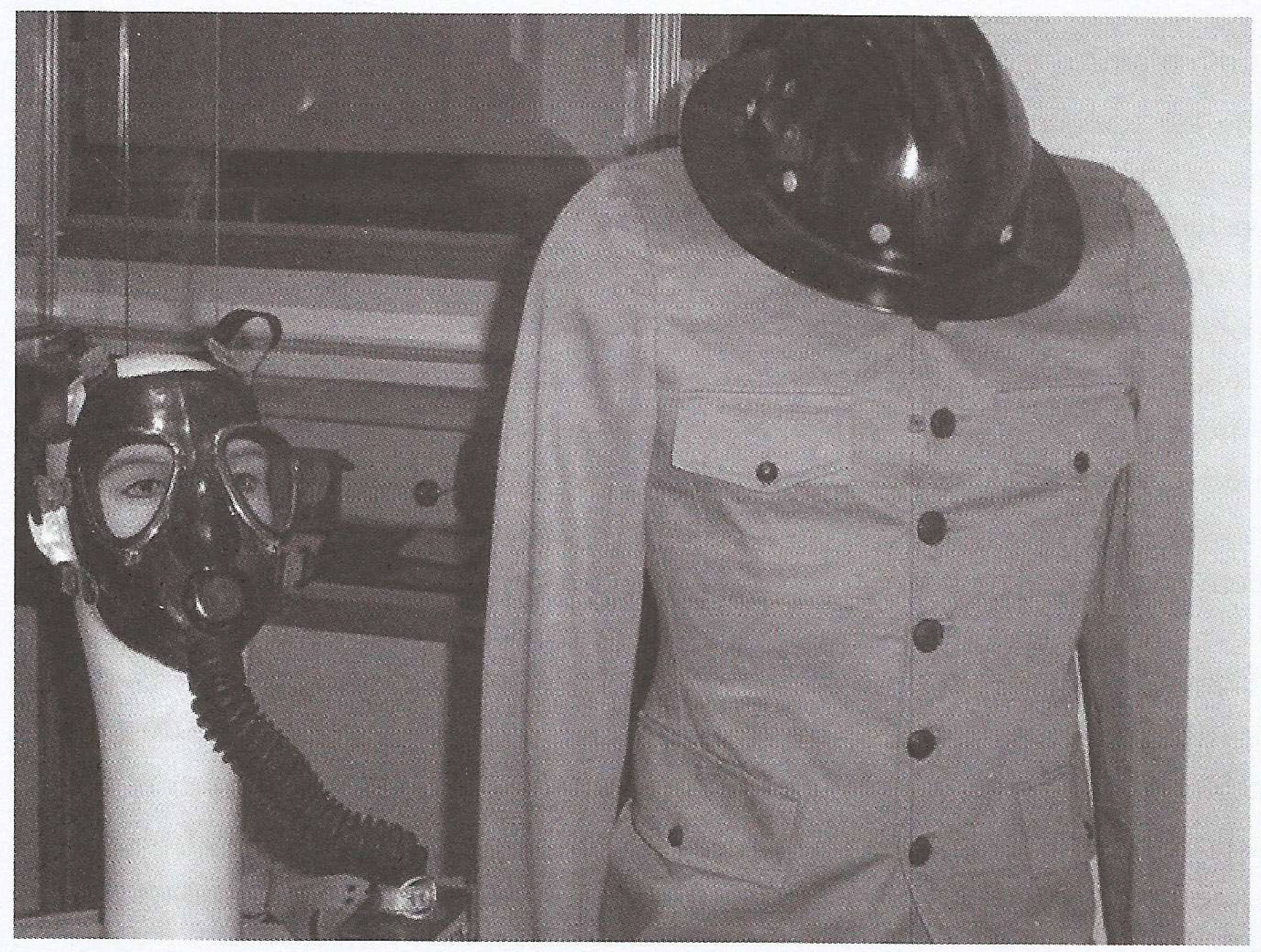

Certamente, não é esse Guarda da Sucam que é homenageado no museu. Que outros elementos lhe são então integrados, de modo a torná-lo digno de ser corporificado e imortalizado no museu? Que valores e ideias lhe são atribuídos na composição construída na exposição que possibilitam compreender sua transformação em um ícone da saúde pública em um museu institucional?

Minha sugestão, com base na reflexão sobre o simbolismo das peças do museu e de entrevistas realizadas com funcionários da Funasa
Figura 2 - Manequim Guarda da Sucam, Museu da Funasa

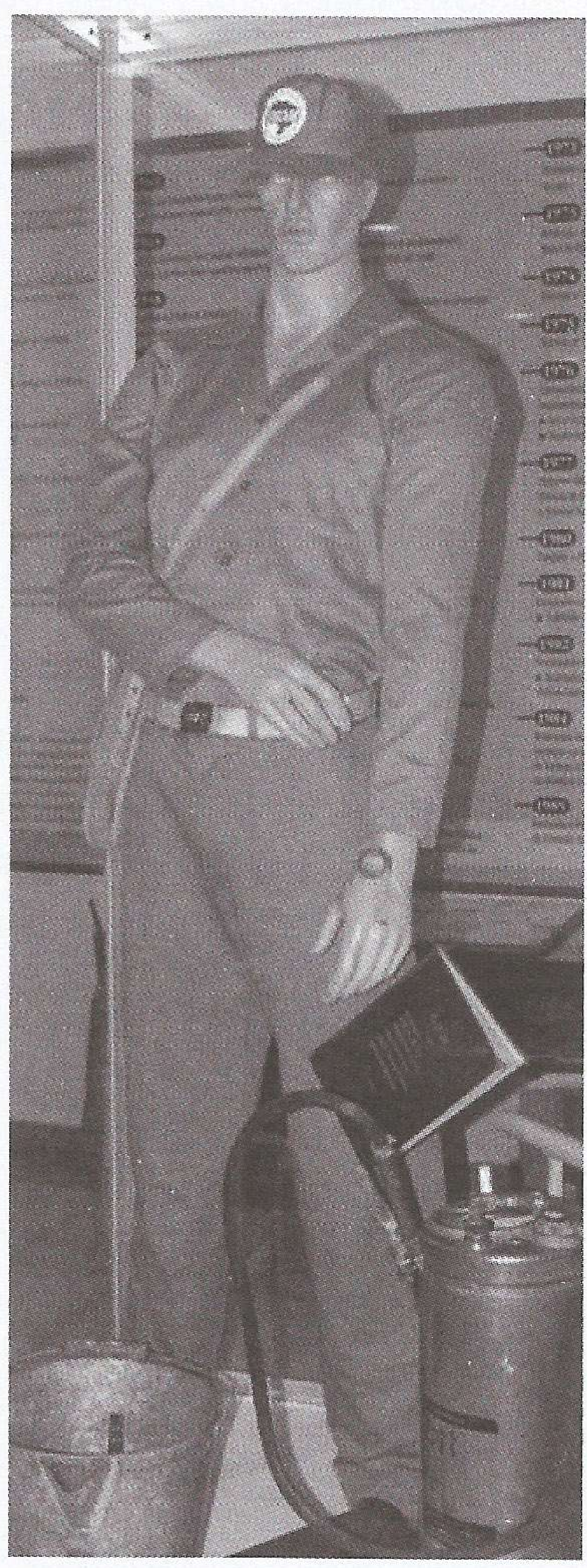


oriundos da Sucam, mas cuja memória também é compartilhada pelos demais, é que a chave interpretativa desse processo de monumentalização do Guarda da Sucam desdobra-se em dois eixos: a afirmação de sua origem local e de sua dedicação ao exercício da função. A tematização iconográfica destes dois valores, enraizamento e vocação, permite que o processo histórico no qual ele se insere adquira novo significado de modo que o Guarda, e não mais o processo abrangente de hierarquia e disciplina em que se insere, seja compartilhado, celebrado e relembrado de forma plenamente compatível com o horizonte democrático contemporâneo (Casey, 2004).

Os guardas de epidemiologia, que solitariamente desenvolviam seu trabalho humilde, porém de transcendental relevância, tinham como atribuição visitar mensalmente um certo número de domicílios, em determinadas localidades, a ele designadas. Os objetivos dessas visitas eram a busca de suspeitos, dos quais ele colheria amostra de sangue e aos quais administraria o tratamento presuntivo, e a divulgação dos postos de notificação localizados em sua área de trabalho. Cabia a ele também o tratamento radical de doentes. (...)

Muitas vezes, os guardas de epidemiologia eram responsáveis por itinerários geograficamente extensos, tendo que almoçar ou mesmo pernoitar fora de sua residência em diversas ocasiões. Transportavam então consigo, em marmitas, o almoço pronto, que deveria ser requentado. Em Santa Catarina, pela relativa pequena extensão da área malárica, raramente havia necessidade de os guardas de epidemiologia pernoitarem fora. Porém, em outros Estados do Brasil, como Amazonas, Pará, Mato Grosso, não era incomum eles saírem da residência no início do mês e retornarem somente no final do mês. Nestas condições, era frequente que os guardas pernoitassem nas casas dos moradores, a eles oferecidas com boa vontade, ao longo do seu extenso itinerário. (São Thiago, 2003: 65-66)

Esse relato expressa, qualifica e perpetua ambos os valores mencionados (inserção local/enraizamento e dedicação/vocação) ao adjetivar o trabalho do guarda de epidemiologia como ao mesmo tempo "humilde" e de "transcendental relevância", articulando como argumentos de sustentação, por um lado, sua pertença local com a sua aceitação (e consequentemente a de sua atuação) pelos moradores; e, por outro, a duração das jornadas de trabalho com seu afastamento da vida doméstica e a solidão em decorrência disso. Os quadros com desenhos do guarda utilizando diferentes meios de transporte (Figuras 3 e 4) e sempre sorridente, expostos no museu próximo ao manequim do Guarda da Sucam, parecem justamente convidar o visitante a compartilhar, simultaneamente, sua intimidade com essa experiência de viajante e sua disposição e satisfação na realização do trabalho.

Contudo, o potencial de abdicação do Guarda da Sucam apresentava-se também, e talvez principalmente, no risco do manuseio de material químico necessário à execução de várias campanhas (inseticidas diversos e gases) - um perigo que é indicado de forma espetacular para o visitante logo na entrada da exposição, pela 
visualização da já mencionada máscara de proteção usada pelo guarda na aplicação de cianogás no combate à peste (Figura 1). Embora eu tenha diretamente experimentado tais significados em minhas visitas ao museu, é importante destacar que não teço interpretações idiossincráticas, já que tais sensações e percepções conectam-se com observações de outros visitantes, relatos dos próprios guardas, dos que com eles conviveram e, no caso específico do manejo de produtos químicos, com as muitas notícias sobre intoxicação e morte de Guardas da Sucam pelo manuseio do pesticida diclorodifeniltricloroetano (DDT) no combate à malária. ${ }^{13}$

Figura 3 - Quadro do Guarda da Sucam, Museu da Funasa

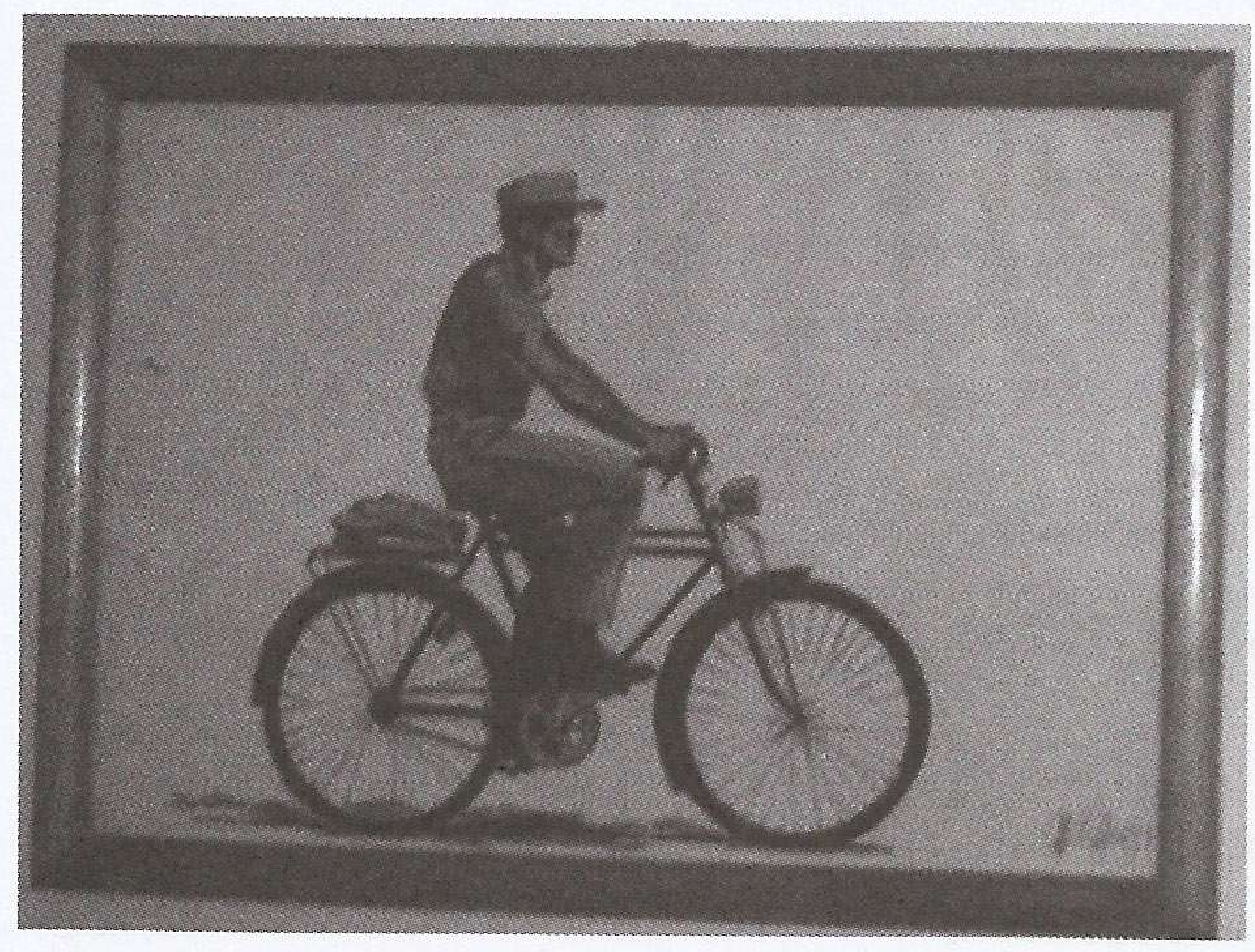

Figura 4 - Quadro do Guarda da Sucam, Museu da Funasa

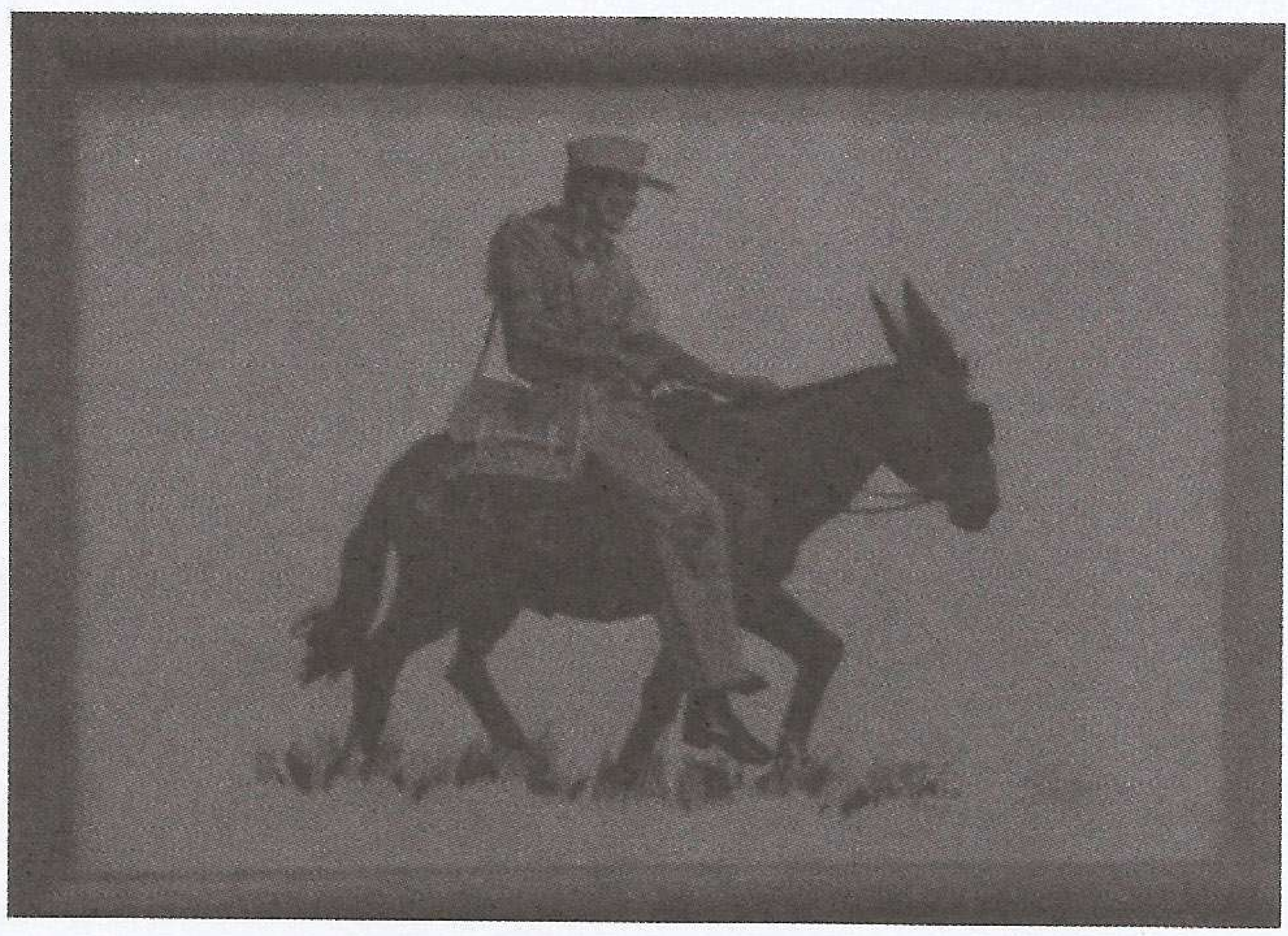

Todos esses elementos, somados aos evocados pelas peças de cada uma das doenças que compõem o museu, vêm a constituir, por meio de sua rememoração nesse espaço público, um momento de ouro da saúde pública encarnado no perfil heroico do Guarda da Sucam. Um momento - cuja referência cronológica flutua $^{14}$ - que fala de uma junção entre vontade individual e coletiva, do futuro como progresso por meio da luta pela erradicação de doenças endêmicas e, articuladamente, como condição de sucesso da própria nação brasileira. Essa articulação entre ações de saúde pública e construção nacional no Brasil tem sido objeto de investigação em diferentes períodos da história e em diálogo com pesquisas também em outros contextos nacionais (Castro Santos, 1985; Hochman, 1998; Lima G Hochman, 2000; Lima et al., 2005), mas no museu ela aparece de forma singela numa peça dotada de forte poder de condensação de significados, de comunicação visual imediata de múltiplas mensagens. Trata-se de uma coleção de conchas das três espécies do caramujo transmissor da esquistossomose classificadas e emolduradas em fundo azul, trazendo as indicações do colecionador na base; no alto, acima de todos os demais elementos, lê-se a inscrição: "Em homenagem à semana da 
pátria" (Figura 5). Essa composição sobrepõe numa mesma peça compromisso patriótico, vetores de transmissão, interesse de colecionador, função na ação direta na erradicação da doença e, dessa forma, por meio da conexão metonímica entre os diferentes elementos enquadrados, cria uma totalidade que remete o visitante ao horizonte de sentidos que o trabalho deveria ter para aquelas pessoas: transcendendo o exercício estrito de um labor, o trabalho como conhecimento, engajamento e vocação insere aqueles que o abraçam no domínio da vida cívica plena.

Desse longo período, ficaram algumas reminiscências, como momentos-símbolos de uma luta renhida, em que se investiram, não apenas recursos financeiros e materiais, mas também entusiasmo e dedicação, em todos os níveis hierárquicos. Do técnico ao guarda, havia um genuíno sentido de engajamento e participação. Logrou-se a façanha de incutir na equipe e em cada um dos servidores o senso de responsabilidade e a consciência da importância do trabalho que realizavam. Ainda que atuando muitas vezes de maneira isolada e distante de sua sede, cada um deles estava plenamente ciente dos objetivos a serem alcançados e davam tudo de si para contribuir com tal desiderato. (São Thiago, 2003: 84)

Figura 5 - Quadro (doação) da classificação do Schistosoma mansoni, Museu da Funasa

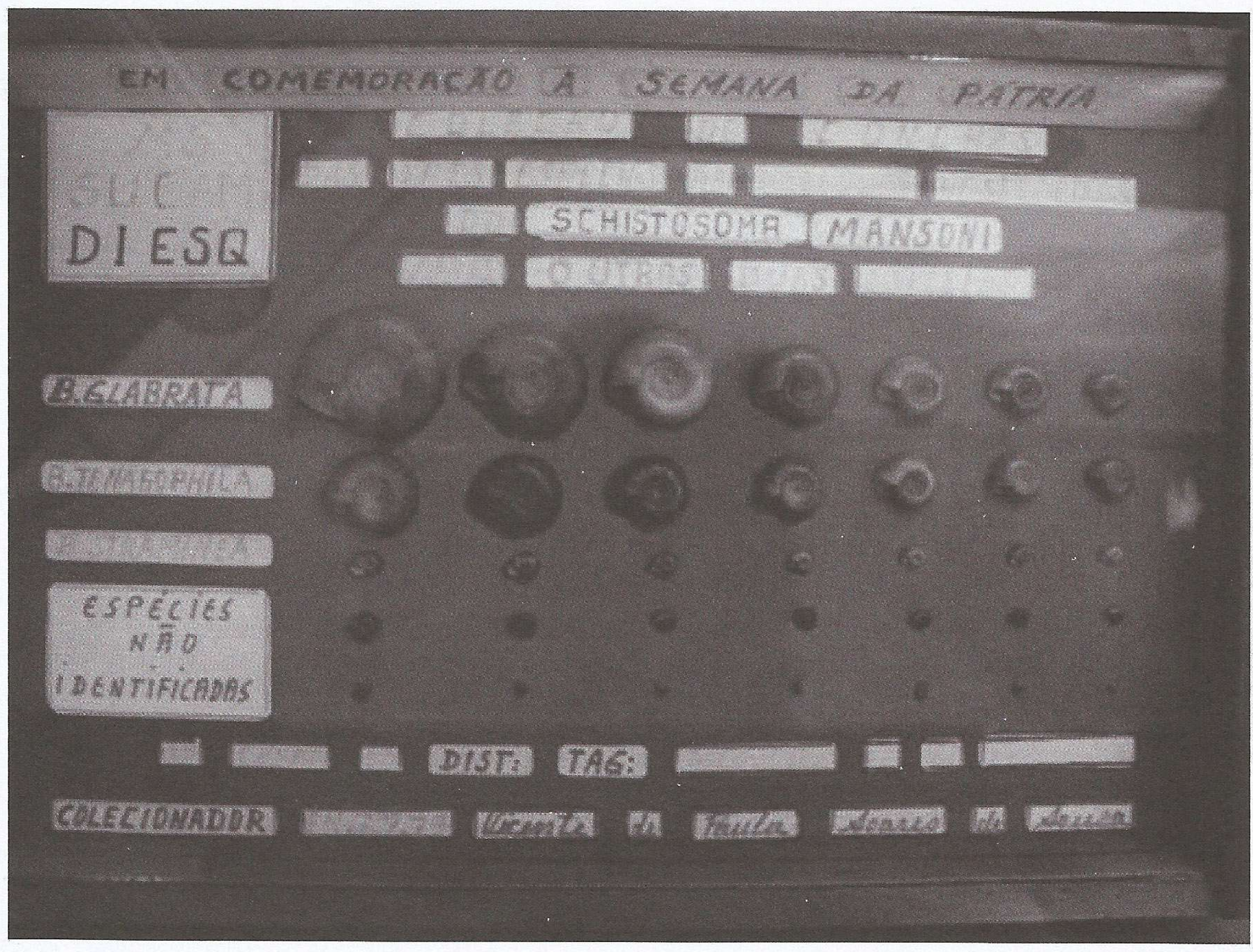


Talvez o objeto mais exemplar desse perfil heroico e vocacionado construído no museu seja a hélice de barco confeccionada em madeira para reposição da peça danificada na embarcação e garantia do término da missão (Figura 6), assim como a carta manuscrita pelo próprio guarda que a acompanha expressando o ethos profissional singular que transcenderia a obediência a normas e rotinas. A hélice e a carta, feitos dignos de nota, são mencionados tanto pela coordenadora do museu quanto também em livro publicado pela própria Sucam (Moraes, 1988), como símbolos do espírito de uma época.

Figura 6 - Hélice de madeira, Museu da Funasa

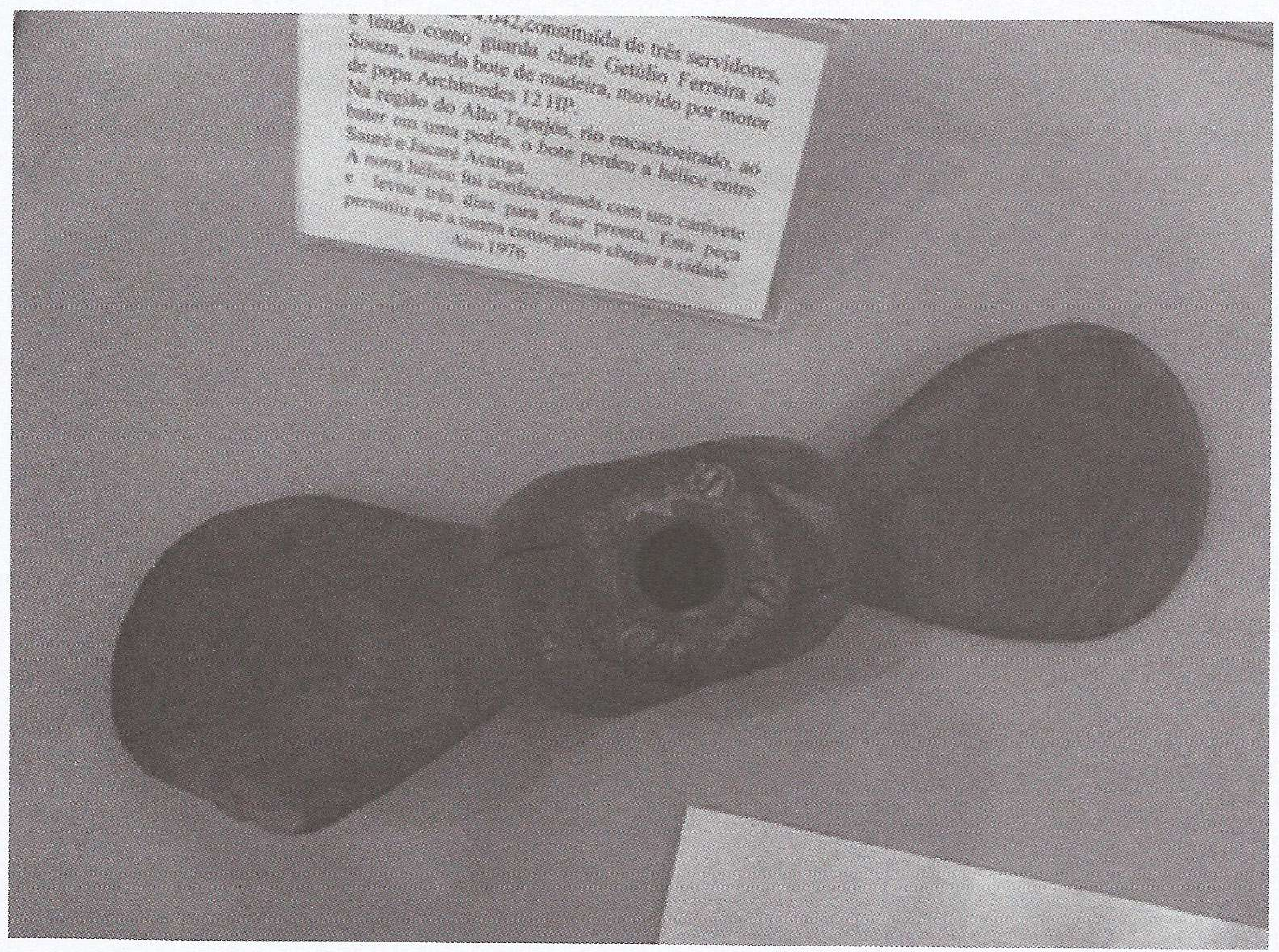

A compreensão da função memorial desse museu requer, contudo, também algumas considerações sobre o seu público, pois este é a condição de realização de sua função. ${ }^{15}$ Trata-se de um museu visitado principalmente por estudantes e profissionais da área da saúde de faculdades de Brasília e de outras cidades próximas - propiciando, inclusive, visitas guiadas por um profissional ex-Sucam que o faz voluntariamente, na qual são detalhadas as informações sobre as peças, sobre o ciclo de transmissão das doenças e, principalmente, são acrescidos relatos pessoais da vivência dessa época. Nesse sentido, é um museu voltado para entendidos, principalmente para aqueles que atuam ou poderão vir a atuar na prestação de serviços na saúde pública. 
Assim, embora a missão oficial do museu seja manter a memória da instituição, no caso a Funasa, parece que sua vocação de fato é propiciar a memorização pública de certas ações de governo pela saúde no Brasil em suas várias experiências de relembrar: 1) a do indivíduo que viveu aquela época e que a relembra por meio dos objetos expostos e das pessoas para quem fala sobre sua própria vivência ao discorrer sobre os objetos; 2) a dos estudantes que imprimem vida aos fatos apreendidos em sala de aula ao serem relembrados por meio dos instrumentos, das fotos, dos espécimes preservados e das representações dos atores principais das campanhas públicas de saúde; 3) mas principalmente o diálogo sobre saúde pública que esse espaço público possibilita entre os diferentes entendidos que o frequentam. Um diálogo cujo foco desejado, cabe destacar, são as memórias objetivadas na exposição e celebradas em seus atores: o Guarda da Sucam, as doenças, os vetores e os instrumentos de combate de uma época em que a linguagem e a lógica de parte da saúde pública eram militarizadas, mas acima de tudo bem-sucedidas e heroicas - e no qual a saúde indígena é inexpressiva.

Se o museu não nos fala apenas sobre o passado, seja com nostalgia, seja com celebração, seu acervo como um processo mnemônico proporciona conexões de sentido temporal também na direção oposta da linha do tempo (o presente e o futuro) não somente no que se refere à orientação de interesses e valores que organiza o próprio acervo, mas igualmente em relação à experiência de memorização pública que possibilita. Nesse sentido, proponho-me a refletir com base no silêncio, ou melhor, no esquecimento do personagem análogo ao Guarda da Sucam na outra instituição central à formação da Funasa, ou seja, o guarda sanitário da Fundação Sesp. Para tanto, na ausência de objetos densos e suficientes para essa reflexão no acervo iconográfico do museu, lançarei mão de outros elementos para compreender tal lacuna: os manuais de formação dos guardas sanitários da Fundação Sesp nos anos 1940 e 1970, estes últimos localizados no acervo documental do próprio museu.

\section{Os Guardas Sanitários: da Fundação Sesp e seus manuais}

A compreensão dos manuais da Fundação Sesp selecionados para discussão requer a introdução do leitor, mesmo que de forma breve, à trajetória institucional dessa fundação, essencial à constituição da Funasa, de modo a qualificar os diferentes momentos de sua história em que os manuais se inserem, a relação de forma e conteúdo existente entre eles e, por tal percurso, construir a própria analogia proposta entre Guarda da Sucam e guarda sanitário da Fundação Sesp.

A Fundação Sesp surgiu em abril de 1960, no governo Juscelino Kubitscheck, a partir da transformação do Serviço Especial de Saúde Pública (Sesp) 
em fundação do Ministério da Saúde. Por tal decisão, o Sesp deixava de ser uma agência bilateral Brasil-Estados Unidos e se tornava um órgão permanente da saúde pública brasileira. Como ressalta Peçanha (1977), essa mudança foi possível porque o Sesp, embora tenha sido criado em 1942 para desenvolver ações sanitárias em áreas brasileiras relevantes para a produção e a exploração de matérias-primas para a guerra (borracha na Amazônia e minérios no Vale do Rio Doce), ${ }^{16}$ desde o início foi conduzido com uma dupla orientação: atender a demandas externas, ou seja, contribuir para o esforço de guerra do governo estadunidense, e também a demandas internas - no caso, o programa de desenvolvimento da era Vargas (Campos, 2006). Por tal vocação institucional, o Sesp ampliou sua atuação territorial e teria conseguido renovar seguidamente os contratos entre ambos os governos e diversificar as fontes de recursos, assegurando sua existência até 1960.17

Ao longo desse processo, o Sesp também diversificou sua atuação sanitária. ${ }^{18}$ Se em um primeiro momento (1942-1949) sua atuação concentrou-se nas áreas de interesse de produção de guerra (Amazônia e Vale do Rio Doce), essa ação implicava iniciativas de controle das doenças transmissíveis existentes, mas logo passou a incluir também a assistência médica e a formação de pessoal de saúde. $\mathrm{Na}$ análise de Peçanha (1977: 75-76):

Face à necessidade de atender as exigências ecológicas próprias de um país subdesenvolvido, fugiu o Sesp ao modelo norte-americano de sanitarismo (que não considera a assistência médica como parte integrante de saúde pública), afirmando-se, a partir de 1942, a assistência médica como uma de suas atividades básicas nos programas de saúde e saneamento. Este fato caracteriza o início da adaptação de um modelo de saúde pública às realidades nacionais, sendo opinião dos sespianos que no Brasil não se pode fazer saúde pública sem assistência médica.

Acompanhando essa consideração baseada na visão dos próprios membros da instituição, é importante ponderar que tal diversificação não apenas atendia à concepção de saúde pública predominante no Brasil, mas também significava uma estratégia de longo prazo via uma rede permanente de unidades sanitárias nas quais se encontravam articulados atendimento médico e ações de esgotamento sanitário e de tratamento de água. Uma estratégia que, como analisado por Campos (2006), permitiu ao Estado brasileiro ampliar sua capilaridade e, ao se fazer assim presente cotidianamente para populações até então fora de seu alcance, internalizar territorialmente a burocracia do governo Vargas (Teixeira, 2008b).

Já nos anos 1940, foi criada a função de guarda sanitário e de visitadoras sanitárias e foram promovidos os primeiros cursos de formação desses auxiliares de saúde no chamado Programa Amazônico. Tais cursos eram realizados com base em um manual concebido especificamente para esse objetivo e desenvolvidos na própria região, de modo a garantir que o treinamento se desse em condições similares às das comunidades de origem dos estudantes, pois a expectativa era que 
eles para lá retornassem a fim de desempenhar sua função. ${ }^{19}$ Em outra ocasião, analisei os manuais e a formação desses dois profissionais, suas atribuições e relação de complementaridade (Teixeira, 2008b); aqui, dado o objetivo deste trabalho, darei ênfase ao Manual para Guarda Sanitário utilizado na formação da turma de 1942 em Itacoatiara (AM), cuja prioridade era o combate à malária e aos parasitos intestinais (Teixeira, 2008b). Antes, porém, apresentarei o contexto institucional em que surgiu o outro manual a ser analisado, o Manual de Saneamento de 1972, a fim de poder discutir ambos os manuais de forma articulada.

Nos anos 1950, o Sesp consolidou sua existência em âmbito nacional, fortalecendo sua atuação no "trabalho de interiorização do saneamento básico" e constituindo uma "doutrina de trabalho" marcada por investimentos em formação de recursos humanos (formação de pessoal auxiliar, cursos de graduação no país e de especialização no exterior), um sistema de trabalho em dedicação exclusiva, pagamento de salários considerados, na época, elevados para os padrões de mercado, e pela valorização do compromisso com a "saúde pública" e com o trabalho de equipe, da hierarquia e da disciplina na organização institucional (Peçanha, 1977). O sucesso alcançado nesse período seria responsável pela criação dentre os seus funcionários de uma elite reconhecida fora da própria instituição como os "sespianos". É a partir desse período, portanto, que o Sesp amplia sua influência no campo da saúde pública brasileira em termos de proposição de modelos e formas de atuação, deixando de se posicionar apenas como executor de ações de saúde e buscando assumir um papel normativo na definição de políticas públicas.

Nesse contexto institucional o Sesp é transformado em Fundação Sesp, com todas as dificuldades, inclusive financeiras, que essa transformação traria (Peçanha, 1977). Dentre as estratégias institucionais observadas a partir dos anos 1960, uma nos interessa mais diretamente: a ampliação do trabalho em sistemas de água e esgoto em pequenas comunidades. Tal atuação seria o campo privilegiado de ação dos guardas sanitários, sendo para esta, portanto, voltado o Manual de Saneamento (MS) de 1972 - além da incipiente atuação no que viria a ser denominada "vigilância em saúde" (condições sanitárias de estabelecimentos comerciais e industriais). ${ }^{20}$ A escolha deste manual em particular deve-se ao fato de ele se apresentar como uma revisão e atualização do Manual para Guarda Sanitário (MGS) de 1944 e do Manual de Saneamento dos anos 1960 (apresentado, por sua vez, também como uma revisão do manual anterior), que: "procurou reunir, em três volumes, o que há de moderno e prático, apresentando, sobretudo, soluções apropriadas às condições existentes nas diversas regiões brasileiras" (ISS, 1972).

Sem dúvida, a leitura dos dois manuais revela ao leitor certa estrutura básica semelhante, embora o Manual de Saneamento de 1972 tenha ampliado sua área de cobertura, como já mencionado. No Quadro 1, mostra-se a divisão em cada um deles. 
Quadro 1 - Comparação entre os manuais de 1944 e 1972

\begin{tabular}{|c|c|}
\hline $\begin{array}{l}\text { Manual para Guarda Sanitário } \\
\qquad(1944)-162 \text { páginas²1 }\end{array}$ & $\begin{array}{l}\text { Manual de Saneamento } \\
(1972)-546 \text { páginas } 22\end{array}$ \\
\hline Saúde e saneamento (p. 1-4) & Prefácio, Sumário e Introdução (v. I, p. 1-16) \\
\hline Doenças transmissíveis (p. 5-15) & Cap. 1: Abastecimento de água (v. I, p. 17-194) \\
\hline Destino dos dejetos (p. 6-39) & Cap. 2: Destino dos dejetos (v. II, p. 195-337) \\
\hline $\begin{array}{l}\text { A proteção dos locais de abastecimento de } \\
\text { água (p. 40-46) }\end{array}$ & Cap. 3: Destino do lixo (v. II, p. 338-380) \\
\hline $\begin{array}{l}\text { Inquérito para saneamento domiciliar } \\
\text { (p. 47-51) }\end{array}$ & $\begin{array}{l}\text { Cap. 4: Controle de artrópodes e roedores } \\
\text { (v. III, p. 381-424)23 }\end{array}$ \\
\hline O sistema de classificação (p. 52-59) & Cap. 5: Saneamento dos alimentos (v. III, p. 425-451) \\
\hline $\begin{array}{l}\text { Preparação dos croquis e dos relatórios de } \\
\text { campo que são necessários para preparar o } \\
\text { mapa de saneamento da cidade (p. 60) }\end{array}$ & Cap. 6: Saneamento nas escolas (v. III, p. 452-461) \\
\hline $\begin{array}{l}\text { Os deveres do guarda sanitário ao voltar ao } \\
\text { seu centro de saúde (p. 61-63) }\end{array}$ & $\begin{array}{l}\text { Cap. 7: Saneamento nos locais de banho } \\
\text { (v. III, p. 464-469) }\end{array}$ \\
\hline Relatórios dos guardas sanitários (p. 63-64) & Cap. 8: Saneamento nas indústrias (v. III, p. 470-477) \\
\hline Suplementos $1-4$ (p. 65-74) $)^{24}$ & $\begin{array}{l}\text { Cap. 9: Saneamento em épocas de emergência e em casos } \\
\text { de calamidade pública (v. III, p. 478-483) }\end{array}$ \\
\hline $\begin{array}{l}\text { Intensificação do saneamento domiciliar } \\
\text { (p. 75-84) }\end{array}$ & $\begin{array}{l}\text { Cap. 10: Noções de topografia; goniômetro prático; } \\
\text { numeração de casas e quarteirões (v. III, p. 484-512)25 }\end{array}$ \\
\hline Saneamento escolar (p. 85-89) & \multirow{2}{*}{$\begin{array}{l}\text { Cap. 11: Materiais de construção; especificações de } \\
\text { materiais de construção para execução de melhorias } \\
\text { sanitárias; relação de ferramentas para montagem de } \\
\text { oficina de saneamento (v. III, p. 513-545) }\end{array}$} \\
\hline $\begin{array}{l}\text { Instruções para observação e classificação } \\
\text { das condições de saneamento domiciliar e } \\
\text { escolar (p. 90-159) }\end{array}$ & \\
\hline
\end{tabular}

Com base na consideração inicial da macrodivisão temática, algumas alterações podem ser atribuídas à destinação específica de cada um dos manuais: - Manual para Guarda Sanitário guiava o curso de formação deste profissional auxiliar, ao passo que o Manual de Saneamento visava a atingir um público mais amplo e uma diversidade maior de perfil de guarda sanitário. Outras, contudo, devem ser relacionadas às mudanças históricas na instituição e no próprio campo das relações entre saúde e saneamento. Assim, temos que considerar a ampliação da atuação da Fundação Sesp para espaços urbanos e suas instalações, enquanto o Sesp inicialmente focalizava a realidade do interior (lembrando que este interior, ou sertão, começava por vezes espacialmente nos arredores das cidades, sendo sertão e urbano, portanto, concebidos contrastivamente). Também é necessário levar em conta a ênfase diferenciada conferida à água no Manual de Saneamento, que diz 
respeito tanto às mudanças político-institucionais (os serviços autônomos de água e esgoto e a expansão dos trabalhos de água e esgoto em pequenas comunidades nos anos 1960) quanto às transformações em âmbito internacional na abordagem da água como prioridade na ecologia das doenças infectocontagiosas, que culminariam na instituição pela Organização Mundial da Saúde (OMS) da International Drinking Water Supply and Sanitation Decade em 1981.

A incursão no interior de cada um desses manuais revela, no entanto, uma riqueza de informações e de orientações de valores insuspeita na enunciação de seus tópicos - a qual, por sua vez, nos indica linhas de continuidade e de mudança relevantes para a discussão em foco, ou seja, as conexões concebidas entre eficácia técnica e eficácia simbólica na proposição das ações de saneamento e saúde.

No Manual para Guarda Sanitário, o capítulo relativo às doenças transmissíveis traz como parágrafo introdutório a seguinte asserção:

Para podermos responder às perguntas do povo que quer saber por que uma privada deve ser construída com um chão sem frestas, ou qual o perigo de beber água de um igarapé que corre através da cidade, é preciso estudarmos as doenças que o saneamento pode prevenir. Há certas coisas que devemos conhecer acerca das doenças que o saneamento combate no Vale Amazônico. (MGS, 1944: 5)

A essa asserção segue-se um conjunto de sete perguntas, das quais o texto destaca quatro como aquelas que "nos dirão justamente os itens que precisamos combater para evitar a doença" (MGS, 1944: 5): de onde veio a doença; como os organismos que produzem a doença foram eliminados da pessoa doente; como penetram numa nova pessoa; e como passam de uma pessoa a outra. Essas indagações servem de guia à organização do capítulo que, após descrever em linhas gerais os "organismos das doenças transmissíveis" (bactérias, protozoários, vermes e vírus), as "fontes de infecção" e "os meios de transmissão", as apresenta de forma especificada para cada "uma das doenças mais importantes que o saneamento pode evitar": febre tifoide, disenteria bacilar, disenteria amebiana, ancilostomíase e ascaridíase. ${ }^{26}$

Assim, a doença, no caso as doenças transmitidas pelos dejetos humanos, é concebida como algo a se conhecer para responder às indagações do "povo" e, indiretamente, dos próprios guardas em formação, sobre a razão de ser das especificações técnicas dos equipamentos sanitários e também sobre as orientações comportamentais. Essa dupla orientação, construção de infraestrutura sanitária adequada e modificação comportamental de seus usuários, e também dos futuros guardas, atravessa e deixa sua marca ao longo de todo o manual, guardando fortes conexões de sentido com a importância alocada à observação e classificação das condições de saneamento domiciliar e escolar.

No capítulo das doenças, as orientações comportamentais se inserem no item "Profilaxia", dizendo respeito principalmente a procedimentos de higiene 
pessoal, como lavar as mãos e os alimentos e dispor apropriadamente fezes e urina, sugerindo assim, timidamente, certa postura que viria a ser denominada educação sanitária. Já o capítulo sobre como observar e classificar as condições de saneamento de residências e escolas nos remete à função de inspetoria que o guarda sanitário desempenhava. Este capítulo consiste em especificações para a construção do "inquérito" domiciliar e das escolas que fazia parte do trabalho do guarda sanitário, tendo dupla utilidade: mapear a localidade (especificando ruas, edificações, cursos d'água etc. e numerando os domicílios) de modo a planejar as intervenções sanitárias a serem realizadas (quais e por onde começar), mas também servir de guia para a fiscalização posterior em visitas periódicas da utilização e manutenção feitas pelos usuários das instalações construídas. Seja no reino da natureza (a transmissão das doenças), seja principalmente no reino da técnica (a construção de equipamentos sanitários), a eficácia física e material está condicionada ao controle dos seres humanos - em outras palavras, à produção de certa eficácia social e simbólica.

Assim, no Manual para Guarda Sanitário de 1944 o detalhamento das condições materiais e técnicas necessárias à produção de sentinas, poços e equipamentos de lavagem de mãos, por exemplo, é acompanhado de especificações de como observar e classificar as condições prévias a esses utensílios e posteriores a sua instalação, ou seja, as condições de sua utilização. Aos croquis, plantas, técnicas construtivas, materiais a serem utilizados e formas de execução, seguem-se roteiros classificatórios por grupo de características mais relevantes para sentinas, poços, disposição do lixo, limpeza de quintal, entre outros, e orientações sobre a abordagem dos moradores em caso de mau uso dos equipamentos - sendo ambos os conjuntos conduzidos pela mesma lógica: certo ou errado, correto ou incorreto, sim ou não, presença ou ausência.

As doenças transmissíveis, embora não destacadas em separado, também se fazem presentes no Manual de Saneamento de 1972 dentro de cada conjunto de ações de saneamento: abastecimento de água, destino dos dejetos, destino do lixo etc., mantendo conteúdo similar ao de 1944. Tal deslocamento, entretanto, parece indicar uma mudança de foco, mais do que apenas uma reorganização ou atualização de tópicos para nova publicação. Embora a especificação técnica das obras de saneamento fosse minuciosa no Manual para Guarda Sanitário, considerando que com base nessas orientações o guarda poderia efetivamente executar as obras sanitárias propostas, no Manual de Saneamento a dimensão técnica se complexifica e se apresenta em um nível hierárquico superior, subordinando definitivamente a dimensão "natural" do ciclo de transmissão da doença, bem como a dimensão "humana" de manejo dos equipamentos e de conduta pessoal. É relevante observar que tal recolocação de prioridade ocorre no momento em que a concepção de saneamento se amplia. Como se pode ler na introdução do próprio manual: 
Segundo a definição clássica, 'Saneamento é o conjunto de medidas visando a modificar as condições do meio ambiente com a finalidade de prevenir doenças e promover a saúde'. É uma definição física, material, que na sua expressão não leva em conta fatores humanos.

Segundo a International Foundation, 'Saneamento é um modo de vida, é a qualidade de viver expressa em condições de salubridade, com casa limpa, vizinha limpa, comércio e indústria limpos, fazendas limpas. Sendo um modo de vida, deve vir do povo, ser alimentado pelo saber e crescer como um ideal e uma obrigação nas relações humanas'. (MS, 1972: 9, grifos meus)

Ainda que não mais se comungue da definição clássica de saneamento, o ideal higiênico se mantém no Manual de Saneamento pela repetição do adjetivo "limpa" com relação aos espaços de convivência humana e de trabalho na transcrição anterior. Se no manual a conexão entre "saber" e "modo de vida" se apresenta de forma mais contundente, a dimensão vivencial do saneamento praticamente desapareceu nas páginas seguintes. Há que considerar nesse aparente paradoxo que a Fundação Sesp se tornou uma instituição mais complexa, apresentando, nos seus relatórios anuais, organogramas com várias subdivisões especializadas. Contudo, a não abordagem das relações humanas no manual não deve ser compreendida apenas - esta é a minha hipótese - com base no fato de que a estrutura organizacional propiciaria que a relação com a população fosse abordada mais especificamente na seção de educação sanitária. Se, de acordo com a lógica administrativa e de planejamento, tal divisão do trabalho poderia operar nas grandes cidades, nas pequenas localidades onde o guarda sanitário atuava dificilmente ela se manteria. Afinal, o trabalho do guarda sanitário nesse período também implicava mapeamento da localidade e visitas domiciliares periódicas, indicando que a dimensão das relações humanas permaneceria parte inalienável da rotina de seu trabalho.

As relações humanas ficaram reduzidas, praticamente, a poucos parágrafos que tratavam da profilaxia das doenças transmissíveis nos capítulos designados a apresentar os tipos de intervenção de saneamento (em termos semelhantes aos do Manual para Guarda Sanitário, ou seja, houve uma mudança de ênfase, não de abordagem). Essa redução requer a reflexão sobre as pretensões normativas prioritárias para a Fundação Sesp nesse momento. Como já assinalado, desde os anos 1950 o Sesp vinha-se posicionando nacionalmente como uma agência executora de ações. Contudo, a qualidade exemplar dessas ações autorizaria o serviço a agir também como agência proponente de modelos para a saúde pública. Assim, conforme analisa Peçanha (1977), a Fundação Sesp manteria e, de fato, intensificaria os esforços para se fortalecer como uma agência reguladora e de normalização. O Manual de Saneamento de 1972 está inserido nesse momento político-institucional da Fundação Sesp em que se busca influenciar a construção das políticas públicas relativas a sua área de atuação, além de também expressá-lo e constituí-lo. Nesse 
sentido, o detalhamento técnico e operativo das ações e dos equipamentos propostos para o abastecimento de água e destino dos dejetos em diferentes contextos é complementado pela apresentação de normas técnicas na seguinte sequência: primeiro há a transcrição das normas existentes e, posteriormente, sugestões de normas.

No caso do abastecimento de água, por exemplo, lemos ao final do capítulo: "Instalações prediais de água fria (Normas da Associação Brasileira de Normas Técnicas, NB-92 ABNT)", em seguida, "Sugestões de normas provisórias para elaboração e apresentação de propostas para pequenos abastecimentos de água" e um glossário. Mesmo as ações que não acarretam explicitamente propostas reguladoras expõem as intervenções detalhadas em projetos inseridos num horizonte maior de planejamento orçamentário e administrativo. A argumentação da apresentação dessas normas e orientações de planejamento consiste, portanto, na constatação de que as normas existentes tratam de soluções para cidades de médio e grande portes que não são viáveis para a realidade das "pequenas comunidades" - contexto em que o Sesp e a Fundação Sesp desenvolveram sua competência de especialistas. Assim, tratava-se de um esforço para ocupar um espaço não normalizado e se colocar em posição de autoridade na construção de políticas nacionais a partir da segunda metade dos anos 1960, no regime político que se iniciou após a tomada do governo pelas forças militares. Nessa perspectiva, a dimensão humana do saneamento - e até mesmo o próprio guarda sanitário - ficaria subordinada nas páginas desse Manual de Saneamento, cuja prioridade tornara-se divulgar a excelência do trabalho da Fundação Sesp, reunindo simplicidade de solução e qualidade técnica em preceitos que pudessem ser universalizados para a realidade diversificada das pequenas comunidades brasileiras - não se restringindo mais às regiões e programas sespianos.

Destaco, por fim, a natureza específica desse tipo de documento de política pública: o manual. A denominação manual significa "guia prático que explica o funcionamento de algo", mas também "compêndio", ou seja, livro que "encerra os conhecimentos básicos de uma ciência, uma técnica, um ofício". ${ }^{27}$ Dessa forma, os manuais são por definição um meio para atingir determinada finalidade técnica ou de conhecimento por um processo de aprendizado das informações que contêm. São, portanto, livros que pretendem falar a verdade sobre o mundo e que devem, se bem seguidos, gerar ações eficazes na realidade a que se referem. Com tal autoridade presumida, têm sido, nas últimas décadas, transformados em ferramenta cada vez mais utilizada na implantação de políticas de governo em diferentes contextos nacionais - embora não tenham adquirido a mesma visibilidade nas investigações dos cientistas sociais. ${ }^{28}$

Assim, na perspectiva da governança da saúde, meu interesse aqui, a relação entre a ação no mundo e o conhecimento sobre ele contida nos manuais analisados - o conhecimento do ciclo de transmissão da doença, sua interrupção por 
meio da execução de procedimentos técnicos e comportamental de ação em modelos para ação - exige reflexão sobre a causalidade pressuposta na relação entre fluxo de coisas materiais (plantas, croquis, fórmulas de cálculo, equipamentos etc.) e fluxo de significados (valores, expectativas, adequação de condutas etc.) que comportam.

Os dois manuais são orientados pela concepção de que a realidade natural e humana pode ser reduzida, por observação e experimentação, a conexões e componentes objetivos e invariáveis, guardando-se as condições determinadas - de modo que, por intervenção humana adequada, as conexões indesejadas poderiam ser modificadas alterando-se as condições em que ocorrem. Inserem-se, portanto, no horizonte iluminista da lógica racional e científica e, nesse sentido, comungam também da premissa de que não sendo o conhecimento igualmente distribuído entre todos os seres humanos, há os que, por ignorância, agem de modo impróprio no seu cotidiano, prejudicando a coletividade e a si próprios em razão de tais comportamentos. Esse é claramente o encadeamento que articula doenças, pessoas e ações sanitárias nos manuais dos anos 1940 e 1970:

Para algumas doenças, nós sabemos tudo o que é necessário para preveni-las, bastando aplicar estes conhecimentos para impedir o aparecimento de casos da mesma doença e mortes por ela causadas. É para isto que trabalhamos na Amazônia, para reduzir o número de casos de certas doenças e evitar a morte que elas podem causar. (MGS, 1944: 1)

Os poucos meios de comunicação do passado podem ser responsabilizados, em grande parte, pela descontinuidade da evolução dos processos de saneamento e retrocessos havidos. Na era em que vivemos, a difusão cada vez maior da língua escrita torna menores os perigos de retrocessos. Aparelhagens modernas de comunicação, tais como o rádio e a televisão, facilitam cada vez mais a difusão da cultura em geral e as noções de saneamento em particular.

Conquistas alcançadas em épocas remotas ficaram esquecidas durante séculos porque não chegaram a fazer parte do saber do povo em geral, uma vez que seu conhecimento era privilégio de poucos homens de maior cultura. (MS, 1972: 10)

Seria necessário, consequentemente, o acompanhamento da ação direta sobre o ambiente natural (pequenas obras de engenharia) por ações de "difusão" de conhecimento de forma que as orientações sanitárias fizessem parte do "saber do povo", que, desse modo, não mais padeceria de doenças oriundas da falta de saneamento. Ainda como consta do Manual para Guarda Sanitário: "A população sadia, depois que foram tomadas as medidas de saneamento, dedica-se melhor ao trabalho, adquirindo assim felicidade e riqueza" (MGS, 1944: 1).

Tal conexão de causalidade direta e unidirecional entre conhecimento/ cultura e transformação do mundo, principalmente do mundo das relações sociais, é, no entanto, tensionada e tornada mais complexa quando observamos a relevância 
atribuída à função de inspetoria do guarda sanitário no Manual para Guarda Sanitário; mas também no Manual de Saneamento, quando, ao abordar as situações de calamidade pública, afirma: "É impressionante a teimosia com que populações retornam a suas moradias situadas em locais sujeitos a cataclismas, enchentes e desabamentos, quando, em muitos casos, seria mais fácil e econômico a mudança definitiva do local." (MS, 1972: 478, grifo meu).

É nessa tensão que os manuais parecem render-se ao fato de que é fundamental fazer mais do que relatar e representar, por meio das orientações técnicas sanitárias, a estrutura causal objetiva que atribuem ao mundo na erradicação de doenças. Não é possível alcançar eficácia material apenas por orientações e ações técnicas. Há algo mais neste mundo que requer outro tipo de intervenção, algo que, como visto ao longo da leitura dos manuais, atravessa suas próprias orientações técnicas: o mundo dos significados. Um mundo rebelde a enquadramentos precisos e unilaterais de causa e consequência - tomando de empréstimo a metáfora proposta por Geertz: "the elements of a culture are not like a pile of sand and not like a spider's web. It's more like an octopus, rather badly integrated creature - what passes for a brain keeps it together, more or less, in one ungainly whole" (apud Schweder, 1984: 19). Justamente esse transbordamento de sentidos, que não pode ser reduzido aos processos cognitivos, será objeto de reflexão na análise do Manual do Agente Indígena de Saneamento.

\section{O Manual do Agente Indígena de Saneamento ${ }^{29}$}

O Manual do Agente Indígena de Saneamento foi produzido pela Funasa em 2006 e compõe um conjunto de sete manuais voltados para a chamada capacitação de pessoas das próprias aldeias indígenas para atuarem nas equipes de saúde e de saneamento nos Distritos Sanitários Especiais Indígenas. Assim, esse manual integra o curso de formação dos agentes indígenas de saneamento, que tem como objetivo explícito tornar os agentes aptos a operar e realizar a manutenção dos sistemas de saneamento implantados. O seu conteúdo é organizado em seis capítulos, totalizando cerca de 120 páginas, com a seguinte divisão: Apresentação e Introdução; capítulo 1: "A política nacional de saúde indígena" (p. 9-14); capítulo 2: "O processo saúde/doença" (p. 15-31); capítulo 3: "A importância da água para a vida" (p. 33-91); capítulo 4: "Esgotamento sanitário" (p. 93-107); capítulo 5: "Resíduos sólidos (lixo)" (p. 109-113); capítulo 6: "A participação da comunidade" (p. 115-118); e Referências bibliográficas.

Se a sua proporção, estrutura e articulação com um curso de formação de auxiliares técnicos recrutados no próprio local em que deverão atuar remetem ao Manual para Guarda Sanitário, a ênfase dada à água aponta para a permanência da 
relevância desse eixo de ação na agenda contemporânea de saneamento - dando continuidade, assim, à tendência já observada no Manual de Saneamento dos anos 1970. Uma leitura mais acurada, entretanto, confirma sua filiação principal à configuração de concepções e valores do manual dos anos 1940 sugerida pelo sumário, ao mesmo tempo que permite perceber alterações significativas.

Assim, observamos conteúdos similares no que se refere aos tipos de ação de saneamento a serem implantados e também à presença das relações humanas em seu escopo de preocupações (acrescidos de uma apresentação da Política de Saúde Indígena vigente no país) e, para surpresa do leitor, uma concepção de saneamento que também remonta aos anos 1940. Consta do Manual que a "palavra saneamento significa a aplicação de medidas para evitar transmissão de doenças em nossas casas e cidades" (MS, 1972: 1); e no subitem intitulado "Saneamento básico-água, esgoto e lixo" do Manual do Agente Indígena de Saneamento (MAIS), lê-se: "O Agente Indígena de Saneamento busca contribuir para a higiene de sua comunidade, para prevenir as doenças, atuando no saneamento da aldeia. Saneamento é um conjunto de ações sobre o ambiente, cujo objetivo é proteger a saúde da comunidade ou da aldeia (MAIS, 2006: 12).

É revelador comparar essa definição - e o próprio uso do termo "saneamento básico" - com a apresentada no novo Manual de Saneamento publicado pela Funasa em 2006 (mesmo ano em que lançou o Manual do Agente Indígena de Saneamento). O Manual de Saneamento de 2006, que afirma em sua apresentação ser continuidade do Manual de Saneamento da Fundação Sesp dos anos 1970 e dos que o antecederam, utiliza o termo "saneamento ambiental" e assim o conceitua:

o saneamento ambiental deve focalizar a integração mundial para o desenvolvimento sustentável, garantindo a sobrevivência da biodiversidade e questões prioritárias como o bem-estar e a preservação ambiental. (...)

É o conjunto de ações socioeconômicas que têm por objetivo alcançar Salubridade Ambiental, por meio de abastecimento de água potável, coleta e disposição sanitária de resíduos sólidos, líquidos e gasosos, promoção da disciplina de uso do solo, drenagem urbana, controle de doenças transmissíveis e demais serviços e obras especializadas, com a finalidade de proteger e melhorar as condições de vida urbana. (MS, 2006: 14)

Embora, na definição de saúde, a concepção apresentada pelo Manual do Agente Indígena de Saneamento siga a da OMS - na qual saúde é, mais do que prevenir a doença, um bem-estar físico, biológico e social -, a articulação entre saúde e saneamento revela sua redução, de fato, ao evitamento de contaminação e proliferação de doenças transmissíveis. E, principalmente, indica o que se poderia denominar um uso retórico da definição autorizada de saúde, ou seja, um uso que permite expressar uma posição legitimada no campo sem que este opere como orientação pragmática. Evidencia, assim, um descompasso com as reflexões 
contemporâneas de saneamento, compartilhadas pelos próprios engenheiros do Departamento de Engenharia de Saúde Pública da Funasa, como transcrito anteriormente, principais autores de ambos os manuais, que vinculam o saneamento aos valores de sustentabilidade ambiental e qualidade de vida. Em que constem referências à participação comunitária e aos valores culturais de suas páginas, o conjunto das orientações sanitárias apresentadas pelo Manual do Agente Indígena de Saneamento é normalizador segundo a perspectiva biomédica higiênica e, como discuto mais adiante, deixa a desejar em termos de especificações técnicas.

Como entender, então, que o Manual do Agente Indígena de Saneamento, diferente do Manual de Saneamento da Funasa do mesmo ano, não faça referência aos manuais que o antecederam numa tradição que remonta aos anos 1940, ao mesmo tempo que, de fato, apropria-se da lógica e dos valores que orientaram o Manual para Guarda Sanitário? Essa é uma indagação que requer articulação com o lugar do guarda sanitário, do Sesp e da própria Fundação Sesp, na memória institucional. Se o espírito sespiano usufrui de prestígio e é motivo de orgulho para os atuais funcionários da Funasa (não apenas entre ex-sespianos) pela reconhecida qualidade do trabalho e da formação do seu pessoal, a origem do Sesp como parte do esforço de guerra Brasil-EUA, justamente o período em que o Manual para Guarda Sanitário foi criado, assume caráter negativo ao implicar certa subordinação aos interesses estadunidenses. Ao mesmo tempo, o guarda sanitário não obteve como o seu similar na Sucam um lugar de destaque na memória institucional, seja pela importância dos profissionais de nível superior no projeto sespiano de instituição normalizadora, seja porque o próprio saneamento veio ao longo da segunda metade do século XX, sendo deslocado do campo da saúde para o de infraestrutura urbana e rural - ficando a saúde equacionada principalmente às ações de prestação de serviços médicos, de imunização e de combate ao vetor por meio do uso de inseticidas.

Nessa configuração, a estratégia narrativa do Manual do Agente Indígena de Saneamento revela outros objetivos: inserir as orientações técnicas sanitárias do passado nos valores atuais da Política Nacional de Saúde Indígena, ou seja, o controle social e a participação dos indígenas, por um lado, e o respeito à diversidade cultural, por outro. Essa é a razão pela qual já em suas primeiras páginas, na Apresentação, o manual pondera:

Os conteúdos de formação do Aisan constituem domínios de conhecimento que são avaliados permanentemente perante a realidade de cada aldeia. O Manual do Aisan não é fechado, mas refratário [sic] às realidades locais. Não basta que os conteúdos sejam ensinados, ainda que bem ensinados, mas que se liguem aos padrões culturais de cada aldeia/comunidade. (MAIS, 2006)

A definição do conceito de doença, no entanto, sinaliza os limites da consideração possível dos processos e padrões culturais: "Doença é a reação natural do organismo que pode levar o homem ao estado de enfraquecimento e até a morte, 
quando não é tratada" (MAIS, 2006: 16). Com base nessa postulação de verdade, o capítulo sobre processo saúde e doença se desenvolve nos mesmos moldes do Manual para Guarda Sanitário: explicações gerais sobre doenças (transmissíveis e não transmissíveis), formas de transmissão e tipos de parasitos, seguidas de tipos de doença transmissíveis com subdivisões detalhadas em cada uma sobre o que é, como é transmitida e o que fazer para prevenir. Já os capítulos mais técnicos relativos a sistemas de abastecimento de água, esgotamento sanitário e destino de resíduos sólidos, embora apresentem alternativas de intervenção por meio de obras e equipamentos semelhantes às apresentadas na formação do guarda sanitário, são pobres em especificações de procedimentos e materiais necessários à realização das ações propostas e também das condições em que se deve usar cada uma. Diferentemente do guarda sanitário, não se espera que o Aisan seja capaz de realizar mesmo que pequenas obras de engenharia, como sentinas, poços e depósito para lixo, tampouco de participar da decisão sobre a escolha da ação mais adequada para sua realidade. Cabe a ele apenas fazer procedimentos de operação e manutenção dos equipamentos, apesar de as imagens de poços e sentinas, por exemplo, sugerirem visualmente uma expectativa mais abrangente.

O que dizer da outra atribuição do Aisan apresentada no manual, isto é, o desenvolvimento de atividades de educação em saúde, entendidas como visitas domiciliares, diagnóstico participativo, reuniões e palestras? O objetivo geral dessa atividade é explicitado nos seguintes termos logo na primeira página do capítulo sobre a participação da comunidade:

Conhecer e respeitar crenças e tradições da comunidade, saber como ajudar as pessoas a reconhecerem os valores de suas tradições e identificar aqueles costumes que podem ser prejudiciais à saúde, introduzir novas ideias e avaliar as antigas, enfim, aprender com a comunidade e com ela construir o conhecimento é essencial no trabalho do Agente Indígena de Saneamento. (MAIS, 2006: 115)

A função instrumental da educação em saúde anunciada neste parágrafo, como, por exemplo, identificar costumes prejudiciais e introduzir novas ideias, adquire vinculação mais direta com o trabalho do Aisan algumas páginas adiante:

Para garantir o bom funcionamento, a manutenção e a conservação do sistema de abastecimento de água e de outros serviços na aldeia, é indispensável que haja o envolvimento e o comprometimento da comunidade atendida.

Sendo o Agente Indígena de Saneamento responsável pelo funcionamento do sistema de abastecimento de água e de outros serviços na aldeia, ele deverá buscar mobilizar a comunidade mediante a realização de atividades educativas. (MAIS, 2006: 117) 
Também aqui as orientações são genéricas, mas esse é um manual de "orientações técnicas", como consta de seu subtítulo, e seria de se esperar tal generalidade sobre "atividades educativas".

O que não é comum num manual técnico, no entanto, é que as especificações de procedimentos de execução, operação e manutenção dos equipamentos, principal função do Aisan, também fossem insuficientes. Mas o são. Embora o capítulo sobre a água - o mais volumoso - consista em um conjunto de informações que englobam desde o ciclo da água, apresentação de vários tipos de poços, procedimentos de coleta e de desinfecção, rotinas de operação, manutenção e reparo dos equipamentos e materiais usados na confecção de instalações, não são explicitadas as razões tanto desse detalhamento quanto da sequência de informações que o seguem. Assim, pode-se ver no subitem "Peças e acessórios dos sistemas simplificados de abastecimento de água" (grifo meu), numa denominação bem de acordo com a tradição sespiana, uma sucessão de tipos mais utilizados de registros e acessórios (descrição e desenho) sem qualquer explicação sobre quando devem ser usados: registro de pressão, registro de gaveta, válvula de retenção, válvula de pé etc. Tal ausência possivelmente deve-se ao fato de não caber ao Aisan tomar tais decisões. Contudo, permaneceria a pergunta: por que razão, então, o manual dedica seis páginas a tais informações e desenhos?

Do subitem seguinte, "Operação e manutenção de sistemas de abastecimento de água", porém, constam informações centrais para a atuação do agente nas aldeias, mas nele há lacunas significativas no que se refere à orientação para execução dessas tarefas, como se pode verificar no texto: "Revise as tubulações, corrija os vazamentos existentes e pinte as partes metálicas com tinta anticorrosiva" (MAIS, 2006: 69), que acompanha o desenho de um Aisan executando essas tarefas - sem qualquer explicação sobre a forma como revisar, corrigir e pintar.

Ao final tem-se, então, uma profusão de informações textuais, fórmulas e desenhos num conjunto de incompletude que não permite ao Aisan atingir certo grau de autonomia sequer nas funções técnicas restritas - se comparadas ao guarda sanitário - que deve desempenhar. Se a vocação anunciada de manual técnico não encontra ressonância em sua realização objetiva, a interpretação das imagens que ele contém é reveladora, como demonstro a seguir, de uma dimensão valorativa implícita fundamental e, essa sim, bem realizada.

O primeiro desenho do Manual do Agente Indígena de Saneamento, após as fotos e os diagramas do capítulo relativo à Política Nacional de Saúde Indígena, é a ilustração da concepção de saúde que abre o capítulo do processo saúde-doença, acompanhando a definição ampliada de saúde como um "estado de harmonia entre o homem e o ambiente em que ele vive", que seria influenciado pelos fatores físico, biológico e social. Contudo, o que está na ilustração é uma paisagem em que pessoas nuas, seminuas e descalças caminham em um solo onde se visualizam montículos de fezes, num mesmo ambiente compartilhado com animais domésticos, com uma 
casa localizada às margens do curso d'água (Figura 7). Essa composição sugere, portanto, a ausência de saúde e se contrapõe à mensagem explicitada no texto. Nesse mesmo capítulo, a mistura de fezes, pessoas e animais se repete incansavelmente nas ilustrações que acompanham as diferentes doenças transmissíveis por ausência de condições de saneamento: ancilostomíase, esquistossomose, ascaridíase, febres tifoide e paratifoide, amebíase, diarreia infecciosa, teníase, hepatites A e E e giardíase (Figuras 8 a 11), tendo como um de seus temas recorrentes a representação de um indígena (homem, mulher ou criança) defecando no solo próximo a cursos d'água, do lugar de convivência ou de passagem.

Figura 7 - Imagem da saúde

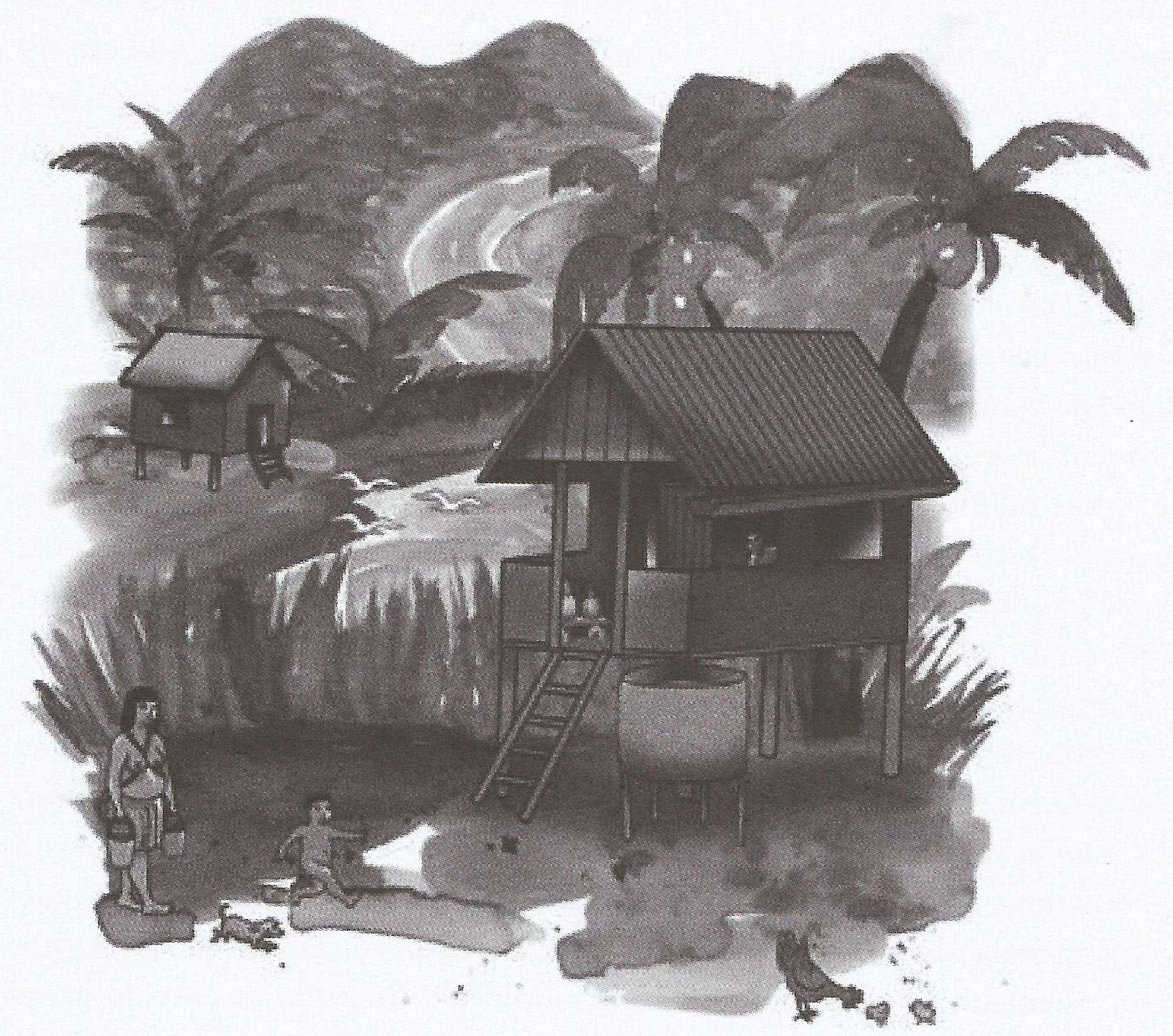

Fonte: Funasa. MAIS, 2006: 15.

Também no capítulo sobre a água encontramos, logo na segunda página, uma ilustração da contaminação do ambiente em que se sobrepõem lixo e animais (rato e urubu e, em destaque, mosca, mosquito e barata), ao lado um indígena de cócoras defecando próximo à água, uma indígena esquelética em primeiro plano, uma carcaça de boi em segundo plano, uma casa ao fundo e, no centro, integrando todos os elementos, um pequeno lago (Figura 12). 
Figura 8 - Esquistossomose

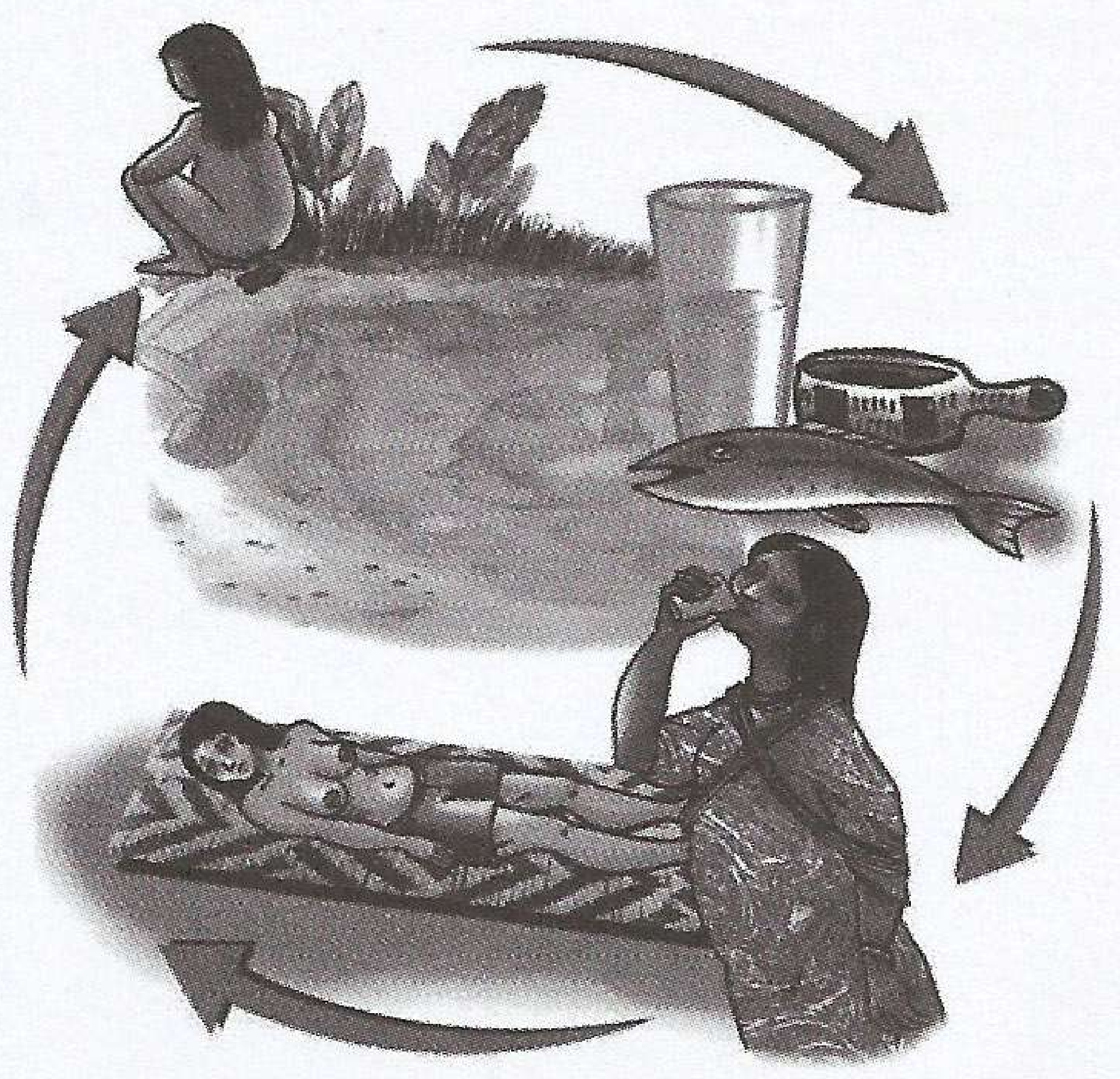

Fonte: Funasa. MAIS, 2006: 21.

Figura 10 - Hepatites A e E

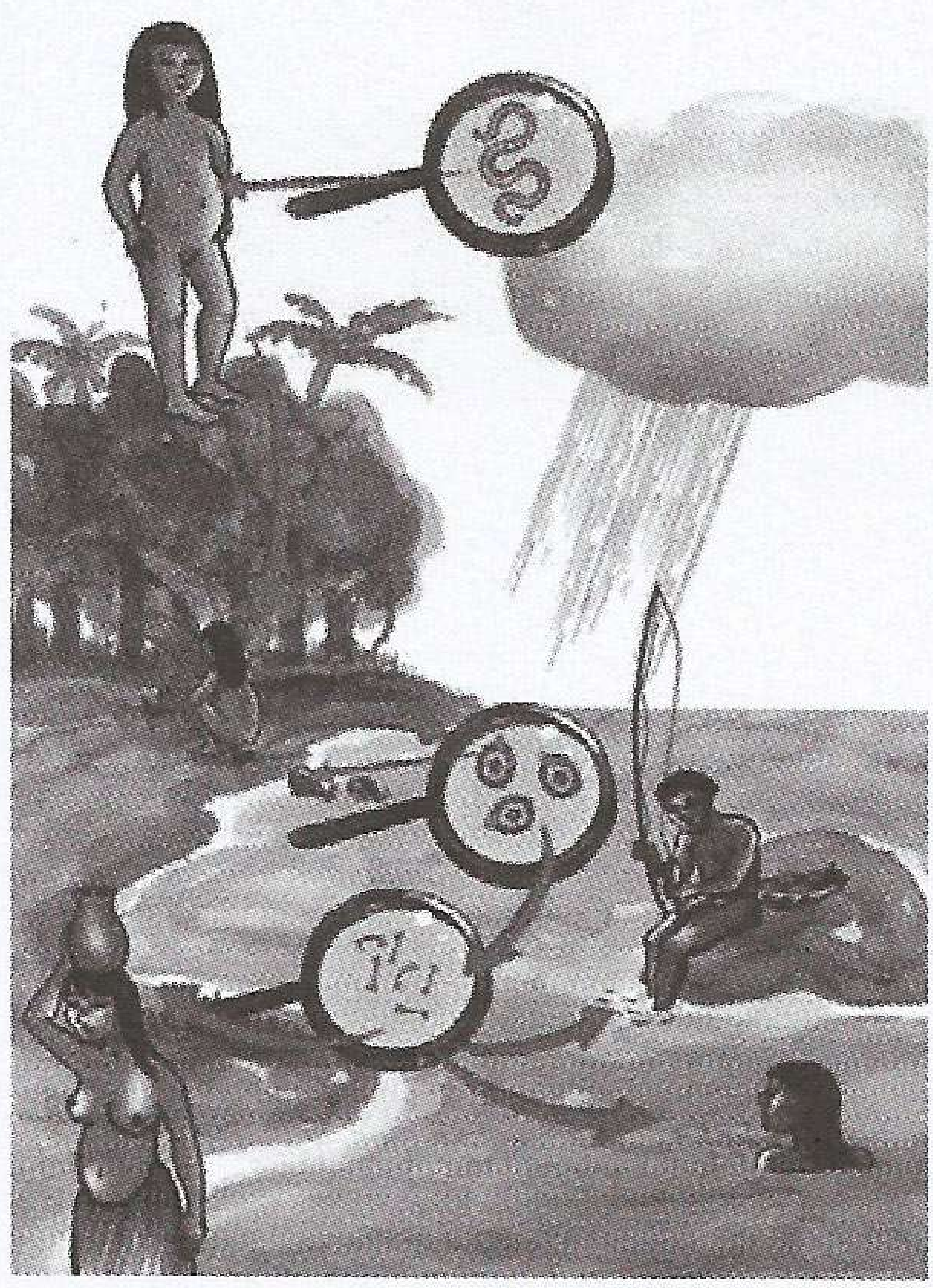

Fonte: Funasa. MAIS, 2006: 28.
Figura 9 - Teníase

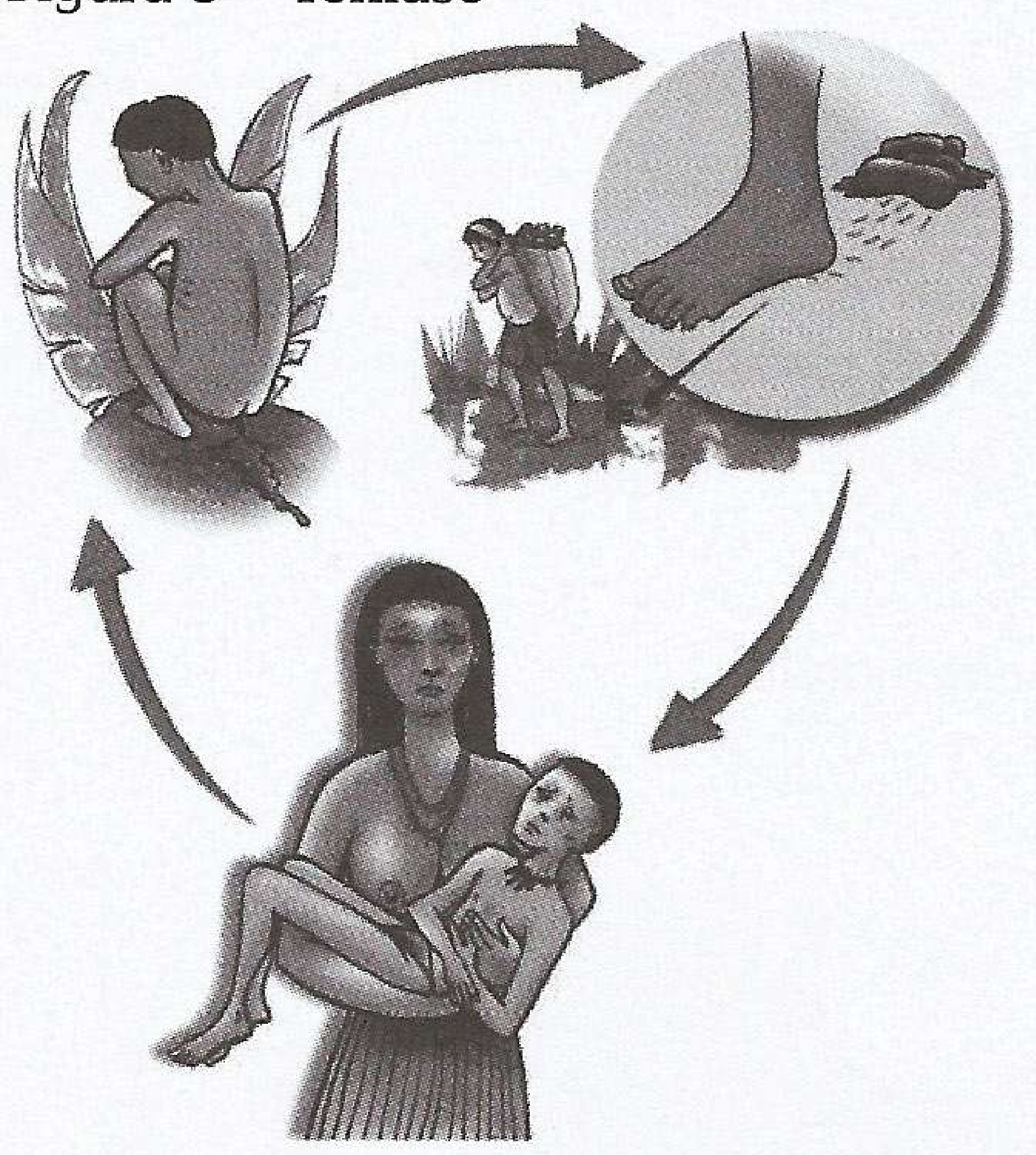

Fonte: Funasa. MAIS, 2006: 27.

Figura 11 - Ancilostomíase

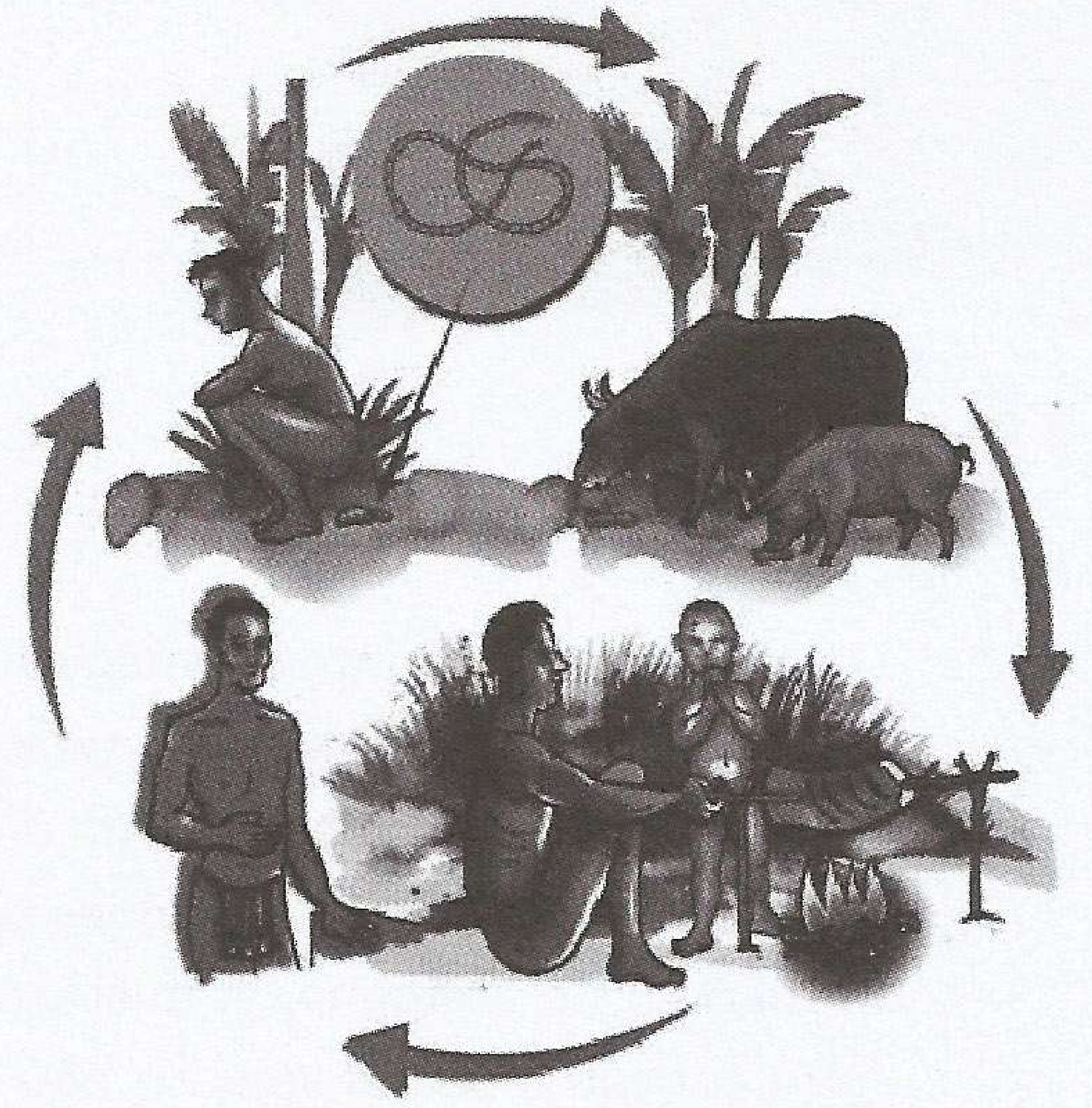

Fonte: Funasa. MAIS, 2006: 20.

O desenho de abertura do capítulo sobre esgotamento sanitário repete a temática: pessoas, fezes, água e animais, simulando um zoom sobre o pé de uma indígena próximo a fezes. Essa ilustração é seguida por uma sequência de três desenhos que mantêm essa mistura e culmina, antes de as ilustrações técnicas se iniciarem, em três representações de indígenas esqueléticos moribundos ou mortos (Figura 13). Entretanto, também na parte de orientações técnicas, vê-se uma indígena defecando numa sentina com casinha, numa exemplificação visual que parece pretender ajudar a compreensão da importância de se construir uma proteção para 
a fossa. Já na parte de orientações quanto ao uso, manutenção e conservação das privadas com vaso sanitário, vemos uma espécie de passo a passo para seu uso, no qual aparece um indígena em cada um dos momentos da utilização do vaso. A página inicial do capítulo sobre lixo, por fim, apresenta uma ilustração, a única, na qual uma indígena descalça próxima a um ajuntamento de lixo expressa corporalmente certo mal-estar com essa proximidade.

Figura 12 - Ambiente degradado

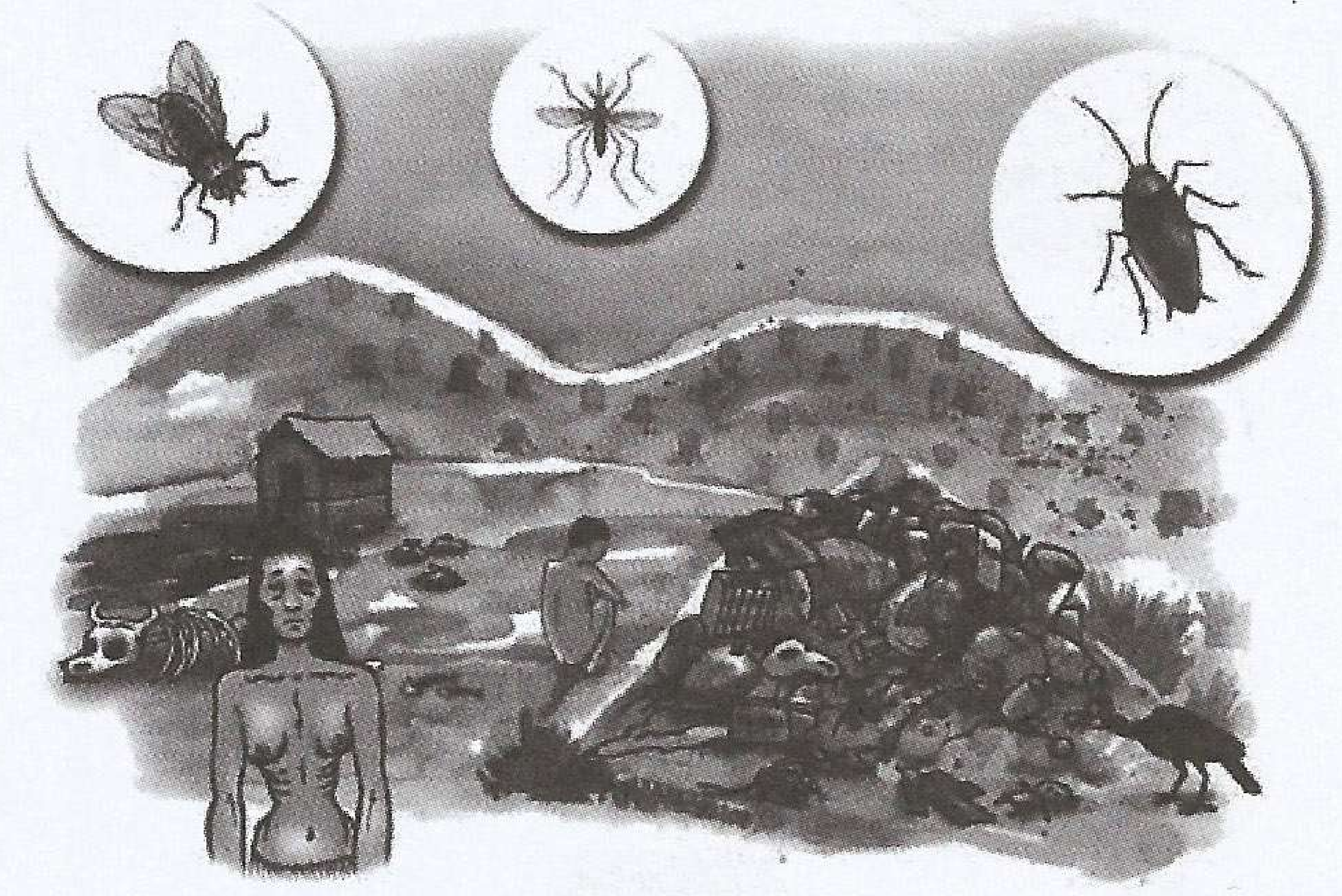

Fonte: Funasa. MAIS, 2006: 34.
Figura 13 - Doenças relacionadas ao esgoto podem levar à morte

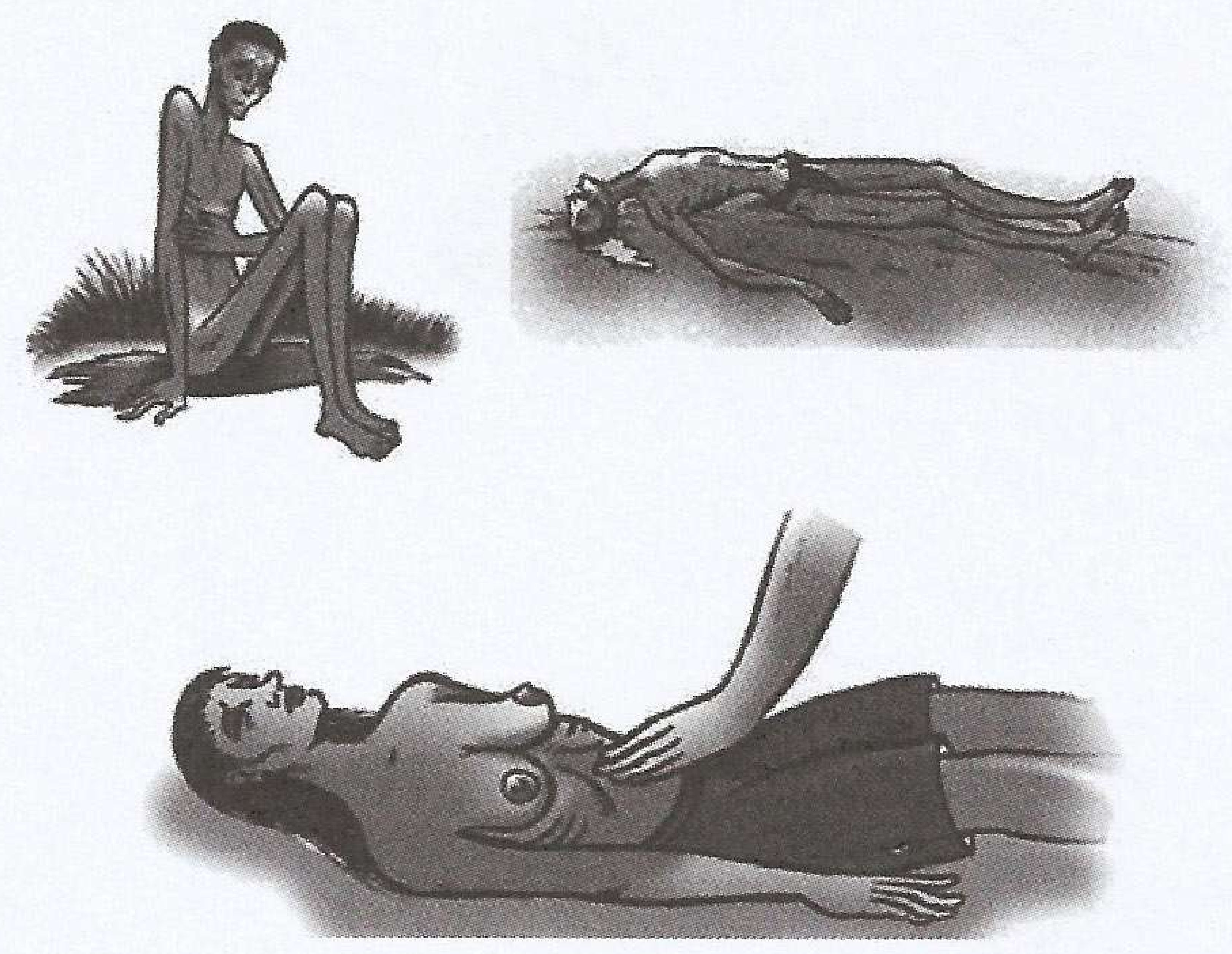

Fonte: Funasa. MAIS, 2006: 95.

Esse conjunto de imagens, embora de forma explícita complemente informações do texto, não são acuradas e mostram por vezes, ilustrações equivocadas, como o desenho do mosquito da dengue, que representa o Aedes aegipty, sem sua principal característica visual: as pernas zebradas. ${ }^{30}$ Contudo, a repetição ao longo do manual de imagens da mistura entre seres humanos, fezes e animais cumpre outra função - tenha sido ou não esta a intenção de quem as criou. Refiro-me à produção de certa distinção social negativa por meio do predomínio da imagética do indígena em meio às suas próprias fezes, convivendo confortavelmente com animais num ambiente por ele degradado - causando e potencializando, assim, no leitor, certa aversão e repugnância pelo conjunto da paisagem, incluindo os próprios indígenas retratados seguidamente como sujeitos principais dessa mistura indevida ao defecarem no solo.

No fim da leitura do Manual do Agente Indígena de Saneamento, confirma-se a impressão inicial de que a relação das imagens com o texto não é a de suporte na transmissão de um conhecimento técnico que permita ações materiais efetivas - como observado no Manual para Guarda Sanitário, cuja única imagem que foge a essa relação é a foto de uma criança com verminose ("O barrigudo"), 
apresentada como o símbolo da má saúde. ${ }^{31}$ As ilustrações do Manual do Agente Indígena de Saneamento, em sua profusão e por repetição, transmitem valores higiênicos de conduta num avassalador processo civilizador a ser protagonizado pelos próprios indígenas, na função de agentes de saneamento.

Assim, se em toda ação humana há sempre duas dimensões - uma técnica e instrumental e outra simbólica e expressiva, que busca comunicar a posição social dos atores -, aqui proponho que, embora se trate de um manual de orientações técnicas, há o predomínio da função simbólica na produção de um lugar de subalternidade social e moral para os indígenas. A fragilidade técnica desse manual, por um lado, revela o lugar inferior que ocupa o Aisan nas equipes de saúde e saneamento, considerado incapaz de discernir entre alternativas e executar procedimentos técnicos mesmo que de baixa complexidade; por outro lado, e, sobretudo, deixa entrever que a proposta de saneamento a ser implantada repousa numa concepção que tem no ser humano o elemento primordial a ser modificado. Se essa orientação já se fazia presente no Manual para Guarda Sanitário, com sua ênfase no trabalho de controle e inspeção do uso dos equipamentos pelos moradores (Teixeira, 2008b), parece ser acentuada em sua versão para o Aisan pela retirada das especificações necessárias à realização de pequenas obras de engenharia sanitária - transformadas num conjunto de generalidades sem condições de aplicação prática.

As imagens são expressivas de um indígena genérico doente por seu próprio comportamento anti-higiênico e sujo, cabendo, portanto, a ele a responsabilidade de interromper o processo de adoecimento por meio da modificação de suas condutas. O que essa abordagem não revela são as precárias condições de saneamento básico em que vivem as populações indígenas brasileiras e também o quanto a imagem de indígenas, principalmente adultos, defecando às margens de cursos d'água é ofensiva para grande parte dos povos indígenas no Brasil.

Num processo perverso de deslocamento de responsabilidade das instâncias governamentais para os povos indígenas, tal iconografia reforçaria atitudes moralmente negativas dos profissionais da saúde e de engenharia que atuam na atenção à saúde indígena e que, com frequência, percebem os indígenas como malcheirosos e sujos, difíceis de lidar e avessos às orientações sanitárias, seja por ignorância, por dificuldade de entendimento ou por serem assim mesmo por sua natureza ou cultura. Todavia, principalmente, essas imagens constituem verdadeiros ícones, ou seja, signos que, por sua capacidade de comunicação imediata e por exigirem pouca reflexão dos leitores, remeteriam diretamente os indígenas a níveis destituídos de uma pertença plena à humanidade, por meio da produção imagética da repugnância, da repulsa e do nojo pela mistura incivilizada e perigosa de fezes, animais e seres humanos.

A repugnância e o nojo estão entre as emoções que afetam diretamente os sentidos e, por essa forte fisicalidade, remetem ao universo das verdades indisputáveis, da natureza inquestionável, mas principalmente àquilo que estaria 
fora da ingerência humana. ${ }^{32}$ São percebidos pelo senso comum como sensações instintivas, surgindo como uma reação e não como propriamente uma ação, pois seria não intencional e incontrolável. Aquele que sente nojo não seria o sujeito da interação, mas seu objeto, pois algo ou alguém seria responsável por lhe suscitar tais sensações. Não se trataria, portanto, de uma atitude, mas de uma ocorrência cuja origem residiria no outro e não no self, assim, para superá-la, haveria que se transformar o repugnante, o nojento, o repulsivo, e não os que o experimentam como tal.

Nessa perspectiva, a repugnância parece delimitar a fronteira da diferença passível de ser tolerada, pois como podemos aceitar e conviver com alguém cuja aparência, odor e modos corporais nossos próprios corpos não suportam? Se é uma diversidade que ofende os sentidos, contudo o faz por meio de processos cognitivos e intersubjetivos que indicam as fronteiras da própria ordem moral incorporada. Afinal, se perceber o mundo é ordená-lo em suas linhas internas e externas, nesse caso a mistura anti-higiênica alegadamente vivenciada pelos indígenas os excluiria dos princípios que orientam, em termos fenomenológicos aqueles que se pode e deve antecipar no mundo da vida como igualmente humanos (do ponto de vista dos não indígenas, é claro).

A repugnância e o nojo expressam, nesse sentido, a diferença perigosa, geradora de mal-estar físico, potencialmente de adoecimento e contágio, mesmo daqueles que não são responsáveis pelas ações repulsivas, revelando, assim, os elos de interdependência ${ }^{33}$ indesejados entre as categorias nós e outros. A diferença que não ameaça, por sua vez, provocaria emoções distintas menos carregadas de expressões físicas, tais como a piedade, a caridade e, em sua versão negativa, o desprezo. Se não há experiência física destituída de moralidade, é possível, entretanto, pensar que certas percepções sensoriais ou emoções cognitivas trazem para sua zona iluminada o polo moral, como a piedade, a caridade e o desprezo, ao passo que outras dramatizam o polo físico, como a repulsa, o nojo e a repugnância. São justamente estas últimas, essa é a minha sugestão, que parecem estar se fazendo mais presentes à medida que aumenta a aproximação cotidiana entre grupos sociais e morais distintos (no caso, povos indígenas e sociedade abrangente em sua pluralidade interna), potencializando, assim, a metamorfose da piedade e do desprezo nesses sentimentos carnais excludentes.

O que parece estar em questão quando vemos esses sentimentos e sensações sendo produzidos em políticas públicas chamadas de capacitação ou de educação em saúde, como na Política de Saúde para os Povos Indígenas aqui abordada, é a sua transformação em uma técnica de governo, que transcende a intencionalidade dos sujeitos envolvidos diretamente, dotada de profunda força antidemocrática. Manejada sob a égide da promoção da cidadania e do respeito à diversidade, tal ação ainda pretende, em nome do bem-estar do outro, ser implantada por meio 
dos próprios indígenas sempre, entretanto, localizados em posições subalternas: participando das equipes multidisciplinares de saúde como agentes indígenas de saúde e saneamento, sendo capacitados nos termos aqui analisados, submetidos à autoridade e aos preceitos médicos e da engenharia sanitária e com frágeis programas governamentais de promoção de carreiras indígenas em cursos de saúde e de engenharia. Claro é que tais técnicas de governo não são passivamente recebidas e incorporadas pelos indígenas, que vêm ao longo do tempo desenvolvendo estratégias de manipulação política e de tradução cultural de valores e práticas com os quais interagiram e interagem num processo permanente de indigenização dos não indígenas. ${ }^{34}$ Contudo, é necessário destacar a forma como as instituições e suas burocracias engendram interações cotidianas de dominação e subordinação profundamente assimétricas e dotadas de forte potencial de eficácia, bem como refletir sobre essa questão.

No universo aqui analisado, observa-se um investimento na capacitação de indígenas que, em nome da inclusão e da participação, caminha na contramão das demandas dos povos indígenas e vem a integrar a configuração ideológica abrangente que tem no indígena um obstáculo a ser superado. Assim, as chamadas políticas públicas, ou seja, o Estado nacional em ações, práticas e intervenções, articulam diferentes dimensões, criam novas subjetividades e preceitos normativos (inclusive, como aqui focalizado, atualizando verdades biomédicas) e, assim, legitimam certa distribuição assimétrica de direitos e deveres entre as diferentes coletividades - por tais procedimentos diferenciados, costuram-se as conexões entre políticas de saúde e de educação, territoriais e de desenvolvimento voltadas para os povos indígenas. A novidade da estratégia governamental para a saúde indígena presente no Manual do Agente Indígena de Saneamento, em relação aos manuais que o antecederam, é sua ancoragem na produção e reforço de percepções físicas e sensoriais negativas (nojo, repulsa e repugnância) com relação aos indígenas que os remetem a um patamar de intolerância de difícil negociação por ser fruto de interações vividas diretamente no corpo. E nessa dimensão as ambiguidades políticas e morais, necessárias ao diálogo, dificilmente perseveram, tendendo a se definir por um dos termos em jogo, ou seja, nos moldes do certo ou errado, sim ou não, tudo ou nada.

\section{Alinhavando o Percurso}

A compreensão plena das condições de eficácia prática do Manual do Agente Indígena de Saneamento requereria o acompanhamento de seu manejo nos cursos de capacitação dos agentes e também de sua utilização, ou não, no dia a dia das equipes de saúde e de engenharia nos Distritos Sanitários Especiais de 
Saúde Indígena. Um empreendimento que tem-se mostrado de difícil negociação institucional, não bem-sucedida até o momento.

O percurso reflexivo desenvolvido aqui, contudo, permitiu mapear por meio das rotas de transmissão das doenças - que em diferentes momentos da história da saúde pública brasileira foram objeto de intervenção das agências governamentais - os caminhos e os mecanismos (práticos e valorativos) do processo de construção da cidadania indígena ainda em curso, por meio da política governamental de saúde em diferentes níveis de atuação. Nessa perspectiva, analisei a ausência da saúde indígena no museu de memória pública da instituição, que tinha como missão gerir a política e os serviços de saúde para os povos indígenas; a monumentalização do guarda da Sucam em detrimento do guarda sanitário do Sesp e da Fundação Sesp, que, como argumentei, seria o equivalente ao atual Aisan; e, sobretudo, o deslocamento do privilégio da relação entre conhecimento e ação no mundo natural e comportamental (em termos de fiscalização) presente no Manual para Guarda Sanitário pela conexão entre, por um lado, sentimentos e emoções e, por outro, ação no mundo natural via desqualificação moral dos interlocutores e objetos dessas ações (os indígenas) no Manual do Agente Indígena de Saneamento. Se a adesão a qualquer e toda regra requer procedimentos de tradução e interpretação para serem efetivadas no dia a dia, a produção de sentimentos, em especial de sentimentos carnais, contém um peculiar potencial diretivo das ações. Embora não estejamos no domínio clássico dos rituais, a imagética corporal analisada pode ser considerada nos termos propostos por Turner (1981), ou seja, emoções que ao serem evocadas por símbolos possibilitam, pela polissemia que lhes é intrínseca, a conexão do corpo e do self com o nível mais abstrato da moralidade, da espiritualidade, dos ideais políticos e, eu acrescentaria, da biomedicina. Afinal, emoções e sentimentos são, nas palavras inspiradoras de Michelle Rosaldo (1984: 143): "[Emotions are] thoughts somehow 'felt' in flushes, pulses, 'movements' of our lives, minds, hearts, stomachs, skin. They are embodied thoughts, thoughts seeped with the apprehension that 'I am involved'."

Assim, o rastreamento de estratégias análogas em outras políticas indigenistas é um desafio importante e pode indicar dimensões sutis de um processo de infra ou sub-humanização dos povos indígenas no Estado nacional brasileiro. Esse rastreamento, em plena vigência democrática e em meio a conquistas obtidas pelos povos indígenas, ${ }^{35}$ revela a complexidade das relações políticas contemporâneas em seus múltiplos níveis descompassados, e que, sem dúvida, pode iluminar também outros contextos nacionais. 


\section{Notas}

1 As pesquisas que possibilitaram a escrita deste capítulo contaram com o apoio do Conselho Nacional de Desenvolvimento Científico e Tecnológico (CNPq) por meio da concessão de recursos ao projeto Fundação Nacional da Saúde: uma antropologia da produção política da diversidade (2006-2008), pelo edital MCT/CNPq 61/2005 - Ciências Humanas, Sociais e Sociais Aplicadas. Já a sua redação se realizou enquanto desenvolvia meu estágio de pós-doutorado no exterior com suporte da Coordenação de Aperfeiçoamento de Pessoal de Nível Superior (Capes).

2 Esse projeto contou com a participação da Organização Pan-Americana da Saúde (Opas), da Fundação Nacional de Saúde (Funasa/MS), da Secretaria de Vigilância em Saúde (SVS/MS), da Universidade de Brasília (UnB) e da Universidade Federal da Bahia (Ufba) e resultou na publicação Avaliação de Impacto na Saúde das Ações de Saneamento: marco conceitual e estratégia metodológica (Teixeira, 2004).

3 A produção intelectual sobre a memória social, coletiva ou pública, vem-se intensificando principalmente desde os anos 1980 e hoje constitui um vasto campo de reflexão em que se encontram envolvidos historiadores, sociólogos, antropólogos, linguistas, filósofos, entre outros. Assim, sugiro para uma entrada nesse campo o artigo de Olick e Robbins (1998) sobre o estado da arte naquele momento; a coletânea mais recente organizada por Phillips (2004), na qual o leitor pode encontrar trabalhos de fenomenologia da memória ausentes no levantamento feito por Olick e Robbins (1998); e a contribuição original de Douglas (1986) para o entendimento do modo como as instituições lembram e esquecem.

4 Gostaria de agradecer aos responsáveis pelo Museu da Funasa, sua coordenadora e funcionários, que desde o primeiro momento me receberam com abertura e disponibilidade em fornecer as informações que solicitava para minha pesquisa. Sem essa colaboração, nem sempre encontrada em espaços de acervos documentais e museológicos, a pesquisa não teria sido possível.

5 Essa descrição refere-se ao ano 2006, momento em que realizei a pesquisa no museu e as entrevistas com vários funcionários envolvidos com os trabalhos do Departamento de Engenharia de Saúde Pública (engenheiros, educadores em saúde, biólogos etc.) e com a Assessoria de Comunicação da Funasa, responsável pela biblioteca, acervo documental e o museu. Quando retornei ao museu, em agosto de 2009, para completar a pesquisa para este capítulo, a sala interativa havia sido desativada e o seu espaço incorporado ao acervo bibliográfico.

6 Essas informações baseiam-se em dados fornecidos pela coordenadora do museu em entrevista realizada em 2006.

7 O Museu da Funasa encontra-se instalado atualmente no térreo de um prédio do Ministério da Saúde localizado na W3 Norte, uma movimentada avenida de Brasília, mas é de difícil visualização para os transeuntes.

8 Não se trata de desconsiderar as dificuldades que envolvem o projeto e a realização de um museu institucional como o Museu da Funasa, no que refere tanto a recursos materiais quanto a recursos humanos (em 2006, o museu contava com apenas quatro funcionários além da coordenadora, dois do quadro de funcionários do ministério e dois contratos e nenhum deles com formação em museologia ou área afim), mas de inserir tais dificuldades em um horizonte abrangente que transcenda motivações pessoais e entraves burocráticos. 
9 Esse arranjo institucional está relacionado também com a reforma burocrática pela qual passava o país no mesmo período sob a gestão do presidente Fernando Collor de Mello (Teixeira, 2008a), que, em nome de eficiência de gestão, tomou várias medidas para diminuir o número de funcionários públicos no executivo federal.

10 Trecho extraído da legenda que acompanha o objeto em exposição.

11 Com a nomenclatura genérica de Guarda da Sucam, usada pelos ex-sucamzeiros e pelo próprio museu, encontravam-se uma divisão hierárquica e uma diversidade de funções, no que se refere tanto ao tipo de endemia quanto ao trabalho predominante realizado. Em sua dissertação sobre a malária em Santa Catarina, São Thiago (2003) descreve a organização administrativa da Campanha de Erradicação da Malária (CEM) transformada em Sucam em sua diversidade: guarda de epidemiologia, guarda de inseticida e guarda de entomologia, além da "hierarquia moral" (São Thiago, 2003) entre guarda-chefe, inspetor e inspetor-geral. Manterei o uso de letras maiúsculas na grafia de Guarda da Sucam por ser essa a forma como o próprio museu se refere a ele nas legendas e no seu menu na Internet, contribuindo, assim, para sua monumentalização.

12 As primeiras campanhas de vacinação tiveram início nos anos 1960, e em 1989 foi registrado o último caso de poliomielite no Brasil (Schatzmayr, Philipps G Leal, 2002).

13 Em consulta à Internet em 26 de outubro de 2009, foram localizadas 317 referências com a entrada "Guarda Sucam DDT", em sua grande maioria, exceto por alguns poucos trabalhos acadêmicos, tratando de notícias sobre demandas, processos, relatos, falecimentos de Guardas da Sucam ocasionado pelo uso do DDT no combate à malária.

14 Para a discussão da ambiguidade temporal no museu e na própria retórica da Funasa, ver Teixeira (2008a), e para a importância do deslocamento temporal na ação política, Teixeira e Chaves (2004).

15 Em Chaim (2008), o leitor encontrará uma investigação instigante com base na análise do livro de visitantes de um museu comemorativo em Jerusalém.

16 É importante também mencionar que o Sesp teve atuação sanitária nas localidades onde foram instaladas bases militares estadunidenses, como Natal e Fortaleza, por exemplo (Campos, 2006).

17 Tanto Peçanha (1977) quanto Campos (2006) apontam para o fato de que em seus últimos anos o Sesp vinha sendo mantido principalmente pelo governo brasileiro, indicando um pendor institucional em termos de atuação exclusivamente nacional, em razão de mudanças no cenário político nacional e principalmente internacional no que se refere à redefinição da geopolítica nas Américas.

18 Sigo aqui a classificação proposta por Peçanha (1977), que divide a existência do Sesp em três períodos: fase amazônica (1942-1949), fase nacional (1950-1959) e o que ela chamou, na época, fase atual (1960-).

19 The Institute of Inter-American Affairs and the Serviço Especial de Saúde Pública. Sub-Project Description. Project: AM-ITA-12B. October, 1944. Acervo Fundação Sesp I, Casa de Oswaldo Cruz, Fiocruz/RJ. 
20 A função de guarda sanitário existe hoje no âmbito da política de vigilância sanitária com esse tipo de atribuição. Para estudos recentes nessa área, ver Duarte e Teixeira (2009), Garibotti, Hennington e Selli (2006).

21 Essa totalização inclui fotos e croquis não paginados.

22 O volume I contém 194 páginas; o II, 185 páginas; e o III, 165 páginas.

23 A preocupação com os animais na transmissão das doenças encontra-se também no Manual para Guarda Sanitário, mas de forma diluída nos capítulos que o compõem.

24 Suplemento 1: "Responsabilidades dos guardas-sanitários do Sesp" (p. 65); Suplemento 2: "O problema dos mosquitos em fossas de sentinas" (p. 66-67); Suplemento 3: "O uso de tampas e caixas de assento nas sentinas" (p. 68-69); Suplemento 4: "Instruções para uso da ficha de sentinas" (p. 70-74).

25 Neste capítulo abordaram-se informações técnicas necessárias ao mapeamento da localidade em que os guardas devem atuar, presentes também no Manual para Guarda Sanitário, embora aqui a ênfase na fiscalização quase não se faça presente.

26 A ênfase em parasitas intestinais, que parece específica à epidemiologia do Vale Amazônico, também se manteria no Manual de Saneamento de 1972, indicando que essa focalização inicial perdurou em certa divisão de trabalho entre o Sesp e a Campanha de Erradicação da Malária (CEM), que viria a constituir a Sucam.

27 Essas definições foram retiradas do Dicionário Priberam da Língua Portuguesa e do Dicionário Aurélio, sendo o primeiro referido ao contexto europeu do uso da língua portuguesa e o segundo ao português do Brasil.

28 As reflexões contidas no trabalho clássico de Elias (1994) sobre manuais de etiqueta não lograram ser traduzidas para análises de manuais governamentais.

29 A análise empreendida nesta seção consiste de uma versão do artigo publicado na Revista de Antropologia em 2012 e anterior a ele, no qual também abordo o Manual do Agente Indígena de Saneamento (Teixeira, 2012).

30 Agradeço aos colegas da Casa de Oswaldo Cruz, onde tive a oportunidade de apresentar uma versão inicial destas reflexões, por terem chamado a atenção para tal equívoco na ilustração.

31 Ver a foto em Teixeira (2008b). Cabe aqui destacar que essa relação de oposição entre informação textual positiva e imagem negativa, ou seja, de definição de saúde e imagem da doença, também está no próprio Manual do Agente Indígena de Saneamento, como observado anteriormente.

32 Além de Douglas (2002), recomendo especialmente a leitura de Miller (1997) e Kolnai (2004) para a discussão dessas categorias.

33 Para a discussão do surgimento da saúde pública mediante elos de interdependência que escapariam ao manejo das partes envolvidas, ver De Swaan (1990).

34 Para os interessados em reflexões sobre indigenização no Brasil, ver Ramos e Albert (2002); para um breve panomara internacional, ver Ramos, Osório e Pimenta (2009). 
35 A Constituição de 1988 assegurou aos indígenas o respeito à sua organização social, costumes, línguas, crenças e tradições e, desse modo, o direito à diferença, ou seja, o direito a serem indígenas e permanecerem identificando-se como tal. Reconheceu também a capacidade processual indígena, estabelecendo que eles têm a legitimidade para atuar em juízo, individual e coletivamente, em defesa de seus direitos e interesses. Consistiu, assim, numa ruptura importante (Cunha, 1987; Araújo et al., 2006) com a tradição tutelar (Oliveira, 1989; Lima, 1995) da política indigenista brasileira.

Fontes

FUNDAÇÃO NACIONAL DE SAÚDE (FUNASA). Manual do Agente Indígena de Saneamento (MAIS). Brasília: Fundação Nacional de Saúde, Ministério da Saúde, 2006.

FUNDAÇÃO NACIONAL DE SAÚDE (FUNASA). Manual de Saneamento (MS). Brasília: Fundação Nacional de Saúde, Ministério da Saúde, 2006.

FUNDAÇÃO SERVIÇO ESPECIAL DE SAÚDE. Manual de Saneamento (MS), v. I-III. Brasília: Fundação Serviço Especial de Saúde, Ministério da Saúde, 1972.

SERVIÇO ESPECIAL DE SAÚDE. Manual para Guarda Sanitário (MGS). Acervo Fundação Sesp I, Casa de Oswaldo Cruz, Fiocruz, 1944.

\section{Referências}

ARAÚJO, A. V. et al. Povos Indígenas e a Lei dos 'Brancos': o direito à diferença. Brasília: Secretaria de Educação Continuada, Alfabetização e Diversidade/Ministério da Educação, Laced/Museu Nacional, 2006.

CAMPOS, A. L. V. Políticas Internacionais de Saúde na Era Vargas. Rio de Janeiro: Editora Fiocruz, 2006.

CASEY, E. S. Public memory in place and time. In: PHILLIPS, K. R. (Ed.). Framing Public Memories. Tuscaloosa, Alabama: The University of Alabama Press, 2004.

CASTRO SANTOS, L. A. O pensamento sanitarista na Primeira República: uma ideologia de construção da nacionalidade. Dados, 28(2): 193-210, 1985.

CHAIM, N. Writing ideology: hybrid symbols in a commemorative visitor book in Israel. Journal of Linguistic Anthropology, 18(issue 1): 62-81, 2008.

CUNHA, M. C. (Org.). Os Direitos do Índio: ensaios e documentos. São Paulo: Brasiliense, 1987. 
DE SWAAN, A. In Care of the State: health care, education and welfare in Europe and the USA in the Modern Era. London: Polity Press, 1990.

DOUGLAS, M. How Institutions Think. Syracuse, N.Y.: Syracuse University Press, 1986.

DOUGLAS, M. Purity and Danger: an analysis of concepts of pollution and taboo. New York: Routledge, 2002.

DUARTE, A. J. C. G TEIXEIRA, M. O. Trabalho e educação na saúde: um olhar na vigilância sanitária. In: ENCONTRO NACIONAL DE PESQUISA EM EDUCAÇÃO EM CIÊNCIAS, VII, 2009, Florianópolis. Anais... Florianópolis, 2009. Disponível em: <http://posgrad.fae. ufmg.br/posgrad/viienpec/pdfs/1157.pdf>. Acesso em: jul. 2014.

ELIAS, N. O Processo Civilizador: uma história dos costumes. v. 1. Rio de Janeiro: Jorge Zahar, 1994.

GARIBOTTI, V.; HENNINGTON, E. A. G SELLI, L. A contribuição dos trabalhadores na consolidação dos serviços municipais de vigilância sanitária. Cadernos de Saúde Pública, 22(5): 1.043-1.051, 2006.

HOCHMAN, G. A Era do Saneamento. São Paulo: Hucitec, Anpocs,1998.

KOLNAI, A. On Disgust. Illinois: Open Court, 2004.

LIMA, N. T. G HOCHMAN, G. Pouca saúde, muita saúva, os males do Brasil são...: discurso médico-sanitário e interpretação do país. Ciência G Saúde Coletiva, 5(2): 313-332, 2000.

LIMA, N. T. et al. (Orgs.). Saúde e Democracia: história e perspectivas do SUS. Rio de Janeiro: Editora Fiocruz, 2005.

MILLER, W. I. The Anatomy of Disgust. Cambridge: Harvard University Press, 1997.

MORAES, H. F. Sucam: sua origem, sua história. Brasília: Sucam, 1988. v. 2.

OLICK, J. K. G ROBBINS, J. Social memory studies: from "collective memory" to the historical sociology of mnemonic practices. Annual Review of Sociology, 24: 105-140, 1998.

OLIVEIRA, J. P. O Nosso Governo: os Ticuna e o regime tutelar. São Paulo: Marco Zero, CNPq, 1989.

PEÇANHA, A. M. M. Fundação Serviços de Saúde Pública - FSESP: um estudo de desenvolvimento institucional. Revista da Fundação Sesp, t. XXI, n. 1: 63-115, 1977.

PHILLIPS, K. R. (Ed.). Framing Public Memories. Tuscaloosa, Alabama: The University of Alabama Press, 2004.

RAMOS, A. R. G ALBERT, B. (Orgs.). Pacificando o Branco. São Paulo: Editora Unesp, 2002.

RAMOS, A, R.; OSÓRIO, R. G. G PIMENTA, J. (Orgs.). Indigenising development. Poverty in Focus, 17, 2009. Disponível em: <www.ipc-undp.org/pub/IPCPovertyInFocus17.pdf>. Acesso em: jul. 2014. 
ROSALDO, M. R. Toward an anthropology of self and feeling. In: SCHWEDER, R. A. G LEVINE, R. A. (Eds.). Culture Theory: essays in mind, self, and emotion. Cambridge: Cambridge University Press, 1984.

SÃo THIAGO, P. T. História da Malária em Santa Catarina, 2003. Dissertação de Mestrado, Florianópolis: Programa de Pós-Graduação em Saúde Pública, Universidade Federal de Santa Catarina.

SCHATZMAYR, H. G.; PHILIPPS, A. M. G LEAL, M. L. F. Erradicação da poliomielite no Brasil: a contribuição da Fundação Oswaldo Cruz. História, Ciências, Saúde-Manguinhos, 9(1): 11-24, 2002.

SCHWEDER, R. A. Preview: a colloquy of culture theorists. In: SCHWEDER, R. A. G LEVINE, R. A. (Eds.). Culture Theory: essays in mind, self, and emotion. Cambridge: Cambridge University Press, 1984.

SOUZA LIMA, A. C. Um Grande Cerco de Paz: poder tutelar, indianidade e formação do Estado no Brasil. Petrópolis: Vozes, 1995.

TEIXEIRA, C. C. Avaliação de Impacto na Saúde das Ações de Saneamento: marco conceitual e estratégia metodológica. Brasília: Ministério da Saúde, 2004.

TEIXEIRA, C. C. Fundação Nacional de Saúde: a política brasileira de saúde indígena vista através de um museu. Etnográfica, 12(2): 323-351, 2008a.

TEIXEIRA, C. C. Interrompendo rotas, higienizando pessoas: técnicas sanitárias e seres humanos na ação de guardas e visitadoras sanitárias. Ciência G Saúde Coletiva, 13(3): 965-974, 2008b.

TEIXEIRA, C. C. A produção política da repulsa e os manejos da diversidade na saúde indígena brasileira. Revista de Antropologia, 55(2): 1-37, 2012.

TEIXEIRA, C. C. G CHAVES, C. A. (Orgs.). Espaços e Tempos da Política. Rio de Janeiro: Relume-Dumará, Núcleo de Antropologia da Política (NuAP), 2004.

TURNER, V. The Forest of Symbols. Ithaca, London: Cornell University Press, 1981. 


\section{De Improvisos e Cuidados: a saúde indígena e o campo da enfermagem}

Uma característica comum a qualquer Distrito Sanitário Especial Indígena (DSEI) é a presença de profissionais da enfermagem, sejam enfermeiros, sejam técnicos ou auxiliares de enfermagem. Ainda que consideremos outras especialidades, como médicos, nutricionistas, pedagogos, psicólogos e antropólogos, por exemplo, os profissionais da enfermagem seguramente constituem parte importante do cotidiano da assistência básica em saúde prestada aos povos indígenas no Brasil. ${ }^{1}$ Por meio desse grupo específico de profissionais são implantados programas de assistência à saúde, de educação em saúde, de formação dos agentes indígenas de saúde, e a própria rotina de postos de atendimento em aldeia está diretamente relacionada à participação de enfermeiros e enfermeiras como supervisores. ${ }^{2}$

$\mathrm{Na}$ análise antropológica sobre o cotidiano de assistência à saúde indígena, não é possível compreender a dimensão organizacional dos serviços sem incorporar a contribuição da enfermagem a esse processo social mais amplo de construção do Subsistema de Saúde Indígena. Embora o aumento recente da participação dos agentes indígenas de saúde e de saneamento seja parte fundamental das estratégias de consolidação dos DSEIs, o campo da enfermagem tem sido um suporte significativo para a forma como o trabalho desses agentes tem se desenvolvido no interior das equipes multidisciplinares de saúde indígena (Garnelo, 2004; Novo, 2010).

Para não incorrer numa visão generalista sobre as profissionais da saúde, fez-se necessário reconhecer algumas especificidades do campo da enfermagem. Nesse sentido, a intenção foi relacionar certos aspectos conflituosos das experiências ocorridas no dia a dia da assistência prestada aos povos indígenas com valores fundantes de um campo profissional que, em geral, fica em segundo plano no debate em torno da articulação entre biomedicina e medicinas indígenas. Muitos dos casos vividos durante o trabalho de campo, realizado por ocasião da tese de doutorado da autora (Dias da Silva, 2010), revelaram uma pluralidade de ideias e valores na atuação dos profissionais da biomedicina. A pesquisa de campo se realizou em 2008 e 2009, durante oito meses, dos quais cinco foram dedicados ao cotidiano de um posto de saúde localizado em uma aldeia Munduruku do Alto Tapajós e três meses 
incluíram as experiências na Casa de Saúde Indígena da região, localizada na cidade de Jacareacanga, Pará. ${ }^{3}$ A etnografia realizada nas instâncias de atendimento do DSEI Rio Tapajós buscou, por um lado, desdobrar a dinâmica de relações de um grupo de profissionais da saúde que sempre foi simbólica e politicamente atrelado à ideia de saúde pública e de construção da nação; por outro, discutir as situações etnográficas da assistência, tendo em vista a contribuição e as especificidades históricas do campo da enfermagem no debate sobre a saúde dos povos indígenas no Brasil.

Em termos da localização da pesquisa como produção engajada nos debates de antropologia da saúde, vale destacar que, assim como Didier Fassin (2012) propõe, tratar-se-ia antes de pensar o entrecruzamento de uma ordem de valores e uma hierarquia de poderes. Desse modo, a posição teórico-metodológica adotada é aquela que permite uma dupla grade de leitura, na qual "a saúde é (...) ao mesmo tempo um constructo social, no sentido em que os agentes sintetizam a linguagem da doença, e uma produção da sociedade, no sentido em que a ordem do mundo se inscreve nos corpos" (Fassin, 2012: 376).

O improviso e o cuidado, ao serem tomados como categorias nativas, significadas por diferentes grupos - das técnicas de enfermagem e o das enfermeiras - no interior da equipe de saúde, têm o poder de sintetizar uma abordagem dual - esta é hipótese - por meio de uma etnografia centrada nos fazeres dos agentes da biomedicina que não limite seu olhar aos dilemas vividos pela figura do médico, considerando que toda a equipe de saúde (re)produz uma diversidade de formações disciplinares, experiências e percepções. Não se trata de apontar responsabilidades, elementos humanos incapazes ou - termo que tem se tornado inadvertidamente comum - insensíveis. Se o cerne da pesquisa se tornou o campo profissional da enfermagem é porque este constituiu uma esfera de ação aproximada ao cotidiano dos povos indígenas nas aldeias. Essa presença cotidiana constrói uma atitude particular nesse segmento, baseada no que parece ser um conjunto de percepções sobre os povos indígenas que dialogam diretamente com a tradição do nosso movimento sanitarista. Portanto, a ação desse ou daquele indivíduo não estará sendo julgada, mas analisada em relação a um conjunto de dados históricos e etnográficos, e também em referência a um grupo a quem se atribuem demandas e significados específicos para a saúde pública (Rizzotto, 2008).

O objetivo neste capítulo, portanto, é relacionar alguns dos valores constitutivos do campo da enfermagem no Brasil - historicamente vinculados à Reforma Sanitária e ao sanitarismo do início do século XX - com uma análise antropológica das atuais relações que envolvem profissionais da enfermagem no cotidiano da assistência básica em saúde prestada aos povos indígenas, por meio dos DSEIs.

Boa parte da etnografia produzida está direcionada às percepções que identificavam os Munduruku como "culturalmente diferenciados" - para usar um termo notório da política setorial - buscando descrever quando, onde e como essa 
diferença era qualificada. Uma das conclusões ao reunir os pontos de vista desses atores sobre seus cotidianos foi perceber que nem sempre os princípios da biomedicina (ordem de valores), num sentido estrito e formal, eram o melhor caminho para compreender as diferenças internas que abrigavam estereótipos sobre os índios e sobre os profissionais da saúde. Por isso, as categorias que orientam este capítulo - improviso e cuidado - contribuem para discernir certa dinâmica de relações entre profissionais da saúde e povos indígenas (hierarquia de poderes) nos postos de saúde em aldeias e nas Casas de Saúde Indígena. Conferir valor à dimensão organizacional como aspecto prático da elaboração de uma ordem de valores é o que se pode ver, por exemplo, nas publicações recentes de Teixeira $(2007,2008)$ sobre a formação de profissionais da saúde pública nos anos 1940, período imediatamente posterior à Reforma Sanitária e sobre a construção de uma memória institucional da saúde indígena no Brasil.

Considerando essas linhas de reflexão, a breve digressão histórica que será apresentada a seguir sobre a constituição do campo da enfermagem no Brasil pautará o debate no tocante às categorias nativas que relacionam as identidades profissionais das técnicas de enfermagem e das enfermeiras. A hierarquia de poderes (dimensão organizacional de distribuição dos serviços de saúde) produzida no interior da equipe multidisciplinar de saúde indígena (EMSI), em que essa rede de relações tem lugar, será o fio condutor que permitirá compreender uma ordem de valores que perfazem a construção da autoridade: 1) das técnicas de enfermagem, para quem o improviso torna-se um elogio social; e 2) das enfermeiras, cuja noção de cuidado está em constante disputa no saber/fazer diário dividido entre cuidar e gerir.

A figura institucional da EMSI foi concebida, no plano da Política Nacional de Atenção à Saúde Indígena (Brasil, 2002), no intuito de reunir uma gama de profissionais especialistas em saúde e outras áreas, a fim de promover uma abordagem múltipla do fenômeno saúde-doença, buscando efetivar o que tem sido chamado de atendimento culturalmente diferenciado ou de articulação entre a biomedicina e as medicinas indígenas. A lógica de atuação dos serviços de saúde e sua dimensão organizacional, porém, conformam em si mesmas uma questão por meio da qual a relação entre essa proclamada multidisciplinaridade e a busca por ações diferenciadas devem ser investigadas. Não se trata de uma análise contrastiva entre o modelo e a realidade, ou entre a teoria e a prática (Langdon G Garnelo, 2004).

Por fim, cabe destacar que a visão de conflito conforme o clássico trabalho de Georg Simmel (1955) orienta a análise em direção à lógica dos próprios atores, que ao se engajarem nas disputas reforçam os laços sociais em torno de seus opositores. Essa noção de que o conflito produz realidades, em vez de ter apenas efeito negativo ou nulo, é fundamental para apreender o contexto da saúde indígena no Brasil, marcado por numerosas divergências de pontos de vista, envolvendo os povos indígenas, profissionais da saúde e antropólogos. Desse modo, o objetivo é 
ampliar o escopo analítico ao focar as interações sociais como espaço de produção de agencialidades, reconhecendo concepções de saúde que podem ser designadas ora como biomédicas, ora como populares ou ribeirinhas e ora como indígenas.

\section{Anna Nery e o Voluntarismo Patriótico: aspectos da consolidação da enfermagem como profissão no Brasil}

Ana Justina Ferreira Néri ou Anna Nery viveu entre 1814 e 1880 e ficou reconhecida como a primeira enfermeira brasileira. Seu legado no campo da enfermagem não será aqui esgotado, entretanto, pretendemos nos próximos dois parágrafos reunir as principais informações sobre sua trajetória, ressaltando a maneira como ela é descrita usualmente nos estudos sobre a história da enfermagem.

Nascida no município de Cachoeira, interior da Bahia, Ana Néri pertencia a uma família de médicos e militares, entre irmãos, marido e filhos. Em 1838, casou-se com um capitão-tenente da Marinha brasileira, Isidoro Néri, natural de Lisboa, com quem teve três filhos e que veio a falecer alguns anos depois. Viúva, Ana Néri mudou-se para Salvador, onde seus filhos seguiram carreira militar, sendo dois deles na condição de médicos. Em 1865, os três filhos, um irmão e um sobrinho foram convocados para a Guerra do Paraguai (1865-1870). Ela escreveu uma carta ao então presidente da província da Bahia, na qual se oferecia como voluntária a prestar serviços na guerra que fossem condizentes com sua "posição e sexo" e destacava sua motivação como brasileira e mãe. Tanto sua carta como a resposta do presidente da província, dr. Manuel Pinto de Souza Dantas, foram publicadas nas edições de 11 e 13 de agosto de 1865, respectivamente, do Diário da Bahia. ${ }^{5}$ Na resposta à solicitação de Ana Néri, o presidente da província destacou que tal "rasgo de patriotismo e abnegação", "digno de inveja", não poderia deixar de ser acolhido e que, para tanto, seriam expedidas ordens do conselheiro comandante das armas que a designariam enfermeira (Cardoso $G$ Miranda, 1999).

Já nos limites da fronteira entre Brasil e Argentina, Ana Néri recebeu treinamento em instituições de irmãs de caridade - como eram conhecidos os estabelecimentos católicos que abrigavam pessoas doentes ou pobres - preparando-se para socorrer os feridos. Durante a guerra, ficou conhecida pelos soldados como "mãe dos brasileiros", por meio de um poema escrito por um voluntário e estudante de medicina, Rozendo Muniz Barreto, que servia nos chamados hospitais de sangue. As homenagens em vida incluíram o recebimento de duas coroas de louros, uma medalha de segunda classe por serviços humanitários prestados e uma medalha de campanha do Exército, além de uma tela a óleo, de 1873, feita 
por um dos pintores mais famosos do Império, Victor Meirelles, ${ }^{6}$ que representou Ana Néri com uma coroa de louros na cabeça e uma de suas medalhas no peito, tendo o campo de batalha ao fundo. A reconhecida enfermeira e heroína de guerra faleceu aos 20 dias de maio de 1880 e foi sepultada no Rio de Janeiro, onde residiu nos últimos anos. Quase cem anos depois, em 1979, seu corpo foi exumado e os despojos enviados à sua cidade natal, Cachoeira, ocupando a nave central da igreja matriz (Cardoso G Miranda, 1999).

É muito interessante a forma como Ana Néri é descrita nesse processo de recuperação da sua trajetória pelos historiadores da enfermagem no Brasil, isto é, uma trajetória que inicia, que instaura, numa temporalidade mítica, a relação entre ser mãe, patriota e enfermeira. Apesar de muitas outras mulheres terem servido na guerra da mesma forma, Ana Néri teria ganhado notoriedade por causa de seu pronunciado voluntarismo, tomado como um valor moral que qualificava sua habilidade natural de cuidar (como mãe) a serviço da nação (Batista, 2005). A participação na guerra se tornou, nesse sentido, o marco fundador a partir do qual Néri se torna símbolo da enfermagem brasileira. Esta é uma informação sobre a qual não há discordância ventre os estudiosos da área. ${ }^{7}$

Por ter sido nomeada e reconhecida como enfermeira pela participação em uma guerra, a sua trajetória logo foi identificada com a de Florence Nigthingale. Esta enfermeira inglesa da era vitoriana e de família aristocrática, contemporânea de Ana Néri, é considerada atualmente a precursora das teorias de enfermagem. Sua legitimidade científica - em contraste com os práticos de enfermagem e as religiosas que se dedicavam aos cuidados dos doentes antes do surgimento da enfermagem como carreira profissional - foi construída a partir de seus esforços no atendimento aos feridos de guerra (Guerra da Crimeia, 1854-1856). Especificamente, pode-se dizer que seu legado, isto é, a prática que ficou associada ao seu nome e a tornou a "pioneira da enfermagem no mundo", se consolidou com o desenvolvimento de um trabalho gerencial na assistência aos enfermos - que buscava diminuir os índices de mortalidade do hospital de campanha por meio do estudo e uso de gráficos, demonstrando aos oficiais do Exército a relação de causalidade entre mortalidade e insalubridade (Kruse, 2006).

Após a guerra, Nightingale dedicou-se ao ensino de enfermagem, por meio do qual pôde implantar o curso de estatística no currículo das enfermeiras, matéria que tomava como fundamental para gerir os problemas de cunho ambiental que se vinculavam aos problemas de saúde (Costa et al., 2009). Em suma, o método Nightingale se centrava na perspectiva epidemiológica e se fundamentava por meio de preocupações com "a alimentação adequada dos doentes, a limpeza e ventilação do ambiente, a troca de roupas de cama, a separação entre feridos e doentes, a higiene dos pacientes, sua privacidade e lazer" (Kruse, 2006: 405-406) - aspectos que, até então, não eram relacionados a uma eficácia dos cuidados de enfermagem 
aos pacientes. Esse aspecto gerencial e administrativo foi o componente novo pelo qual Nightingale se tornou referência primeira e única no campo da enfermagem.

Mas é somente algumas décadas depois, a partir de 1920, com a consolidação da visão sanitarista no Brasil, que se funda a primeira escola de enfermagem ao estilo Nightingale no Brasil. A Escola de Enfermagem Anna Nery se tornou o pilar da formação de enfermeiras de "alto padrão" (título que as diferenciava dos práticos de enfermagem) durante as décadas de 1920, 1930 e 1940 em todo o país. Seu modelo de ensino foi sistematicamente copiado nas escolas que surgiram ao longo do século XX, consolidando-se como a base do ensino universitário de enfermagem (Rizzotto, 2008).

Nesta breve incursão sobre o legado de duas figuras proeminentes da enfermagem, cabe destacar uma tensão que se demonstrou constitutiva do campo entre o cuidado direto das pessoas, dando-lhes banho, fazendo curativos, e a administração dos profissionais e dos processos envolvidos na produção desses cuidados.

Em meados do século XIX, entretanto, essa tensão foi plenamente absorvida pela figura da enfermeira ao estilo Nightingale: ao mesmo tempo que a abnegação e a caridade eram valores fundamentais, a construção de métodos estatísticos possibilitou a conversão da enfermagem em teoria científica. Contudo, a relação entre gerir e cuidar não apenas seria fundadora de um debate de cunho epistemológico e interno à constituição desse campo profissional, mas remeteria à construção social de identidades. Afinal, a legitimidade científica conquistada a partir de Nightingale parecia se opor a qualquer prática de cuidado de enfermagem anterior ao momento em que ela começou a publicar estudos comparativos entre rotinas de hospitais ingleses, franceses, italianos, austríacos e alemães (Kruse, 2006). É estabelecida, assim, uma ordem de valores constituída pela ambiguidade das ações de cuidar e gerir. O estabelecimento de tal ambiguidade entre cuidar e gerir remonta a um debate consolidado sobre o processo de distinção social que orienta a produção de subjetividades nesse campo (Dias Duarte, 2003). Assim, a celebração dessas personalidades na história da enfermagem não diz respeito apenas a seus feitos, mas à disputa entre as habilidades naturais de cuidar atribuídas às mulheres e, por extensão, ao campo da enfermagem e ao cultivo de valores morais como abnegação, caridade e disciplina na luta simbólica por autonomia.

Na segunda leva de homenagens a Ana Néri, que começaram a ocorrer após mais de trinta anos de esquecimento - entre 1887 e 1919 não há menções públicas a ela (Batista, 2005) -, destacam-se eventos que recuperariam em definitivo sua memória no contexto republicano: 1) a Reforma Sanitária da Primeira República, na qual Ana Néri se tornou símbolo da enfermagem e, ao mesmo tempo, da inserção das mulheres na saúde pública, por meio da criação da Escola de Enfermagem Anna Nery, criada pelo Departamento Nacional de Saúde Pública em 1923; 2) a denominação recebida pela Liga das Sociedades Nacionais da Cruz Vermelha como pioneira da enfermagem no Brasil, numa conferência em 1919, em Paris; 3) as numerosas 
homenagens realizadas, durante as décadas de 1930 e 1940, pelas alunas da Escola Anna Nery e pelo corpo de enfermeiras da Cruz Vermelha (Batista, 2005). Pode-se dizer, assim, que o voluntarismo patriótico é o legado por meio do qual Ana Néri se transforma na personalidade Anna Nery, símbolo da enfermagem brasileira. Ao menos esse parece ter sido o valor central a partir do qual se deu a passagem entre sua participação na guerra, da qual ressurge como "mãe dos brasileiros" em meados do século XIX, e a sua ascensão como pioneira da enfermagem brasileira no contexto da Reforma Sanitária do início do século XX.

\section{As Condições Históricas de Produção de Ambiguidades no Campo da Enfermagem}

Anna Nery, como símbolo de patriotismo entre as mulheres no Brasil, foi reabilitada pelo movimento sanitarista do início do século $\mathrm{XX}$ como parte do processo de desenvolvimento de categorias profissionais que pudessem expandir o projeto sanitário. A enfermagem como carreira profissional surgiu, nesse contexto, marcada por uma disputa significativa sobre seu papel. Nessa disputa postulavam-se, pelo lado dos sanitaristas, as visitas aos domicílios e a educação sanitária e, por parte das enfermeiras diplomadas e reconhecidas como de "alto padrão", a administração do ambiente hospitalar e os cuidados a pacientes internados. Aqui, ambiguidade entre cuidar e gerir é inaugurada como uma ambiguidade entre saúde pública e atividade clínica, também formulada nos termos de uma oposição entre um trabalho assistencial e um trabalho gerencial. A enfermagem foi amplamente requisitada pelo movimento sanitarista para realizar as ações educativas que se mostravam imprescindíveis para o desenvolvimento de uma consciência nacional sobre as condições sanitárias do país. As revoltas populares em torno das campanhas obrigatórias de vacinação no período em que Oswaldo Cruz esteve à frente desse processo (1903-1909), entre elas a famosa Revolta da Vacina, pareciam indicar que não bastava aos médicos sanitaristas convencer as elites políticas de seu projeto sanitário. A população pobre surgia como uma questão crucial para o desenvolvimento da perspectiva sanitarista/nacional a longo prazo, aproximando do estudo de Foucault (2004) a respeito do nascimento da clínica na Europa dos séculos XIII e XIX - em que a pobreza ganhou significado vis-à-vis ao desenvolvimento da noção de saúde pública.

Tal disputa nos alerta sobre uma ambiguidade constitutiva no papel da enfermagem que, naquele momento, se expressou por meio da luta das enfermeiras para se distanciarem da "arte de cuidar" - como os discursos de Carlos Chagas exaltavam ${ }^{8}$ - e se engajarem na elaboração de suas próprias teorias sobre o cuidado. Essa ambiguidade parece ter resistido a outros arranjos sociopolíticos e continua a se 
atualizar nos contextos de expansão da enfermagem e da saúde pública. A trajetória de Ana Néri na guerra foi metaforicamente associada à outra guerra (combate às epidemias e doenças endêmicas como febre amarela, ancilostomíase e cólera, entre outras) na qual o voluntarismo e o patriotismo demonstrariam ser também valores morais caros ao processo de formação das políticas de saúde pública e consolidação da carreira de enfermagem.

Ao se indagar como e por que a saúde se torna pública, Gilberto Hochman (2006) contribui para a compreensão do surgimento de novas identidades profissionais no Brasil em fins da década de 1920, coroando um período que se iniciara na Reforma Sanitária de Oswaldo Cruz (1903-1909) e continuaria por meio da expansão do poder público, que resultou no sucesso da construção da noção de autoridade pública por meio das ações de saneamento no Brasil.

O desenvolvimento da enfermagem como profissão ocorre exatamente no auge do sanitarismo, apesar de as formações acadêmicas estarem plenamente engajadas no desenvolvimento de uma enfermagem clínica. Um dos argumentos de Maria Lúcia Rizzotto (2008) é justamente desafiar a ideia, ainda recorrente na história da disciplina, de que a enfermagem tem sua vocação originária e histórica na saúde pública. A autora alerta que os currículos, a participação ativa das enfermeiras norte-americanas e a subsequente influência do modelo anglo-saxão sobre os cuidados de enfermagem comprovam uma clara divergência pouco explorada. Essa contradição se reflete ainda na forma de numerosas ambiguidades pelas quais as profissionais da enfermagem são costumeiramente (in)definidas. Por isso, gostaríamos de pontuar que tais ambiguidades são constructos históricos e políticos de longo prazo e que, no caso da enfermagem, estavam intimamente relacionadas ao lugar imaginado para as enfermeiras no desenvolvimento sanitário do país.

Essa digressão teve como objetivo mostrar que nas bases históricas do processo de formação da carreira de enfermagem no Brasil já podíamos encontrar ambiguidades de diversos tipos sobre a formulação, a execução e a distribuição das atividades de cuidar e gerir que continuam a exercer influência no cotidiano atual da assistência básica em saúde. Destacam-se, especificamente, as condições de produção dessa ambiguidade, cujos significados incidiam sobre o estatuto social das enfermeiras, desvelando uma hierarquia de poderes (cuidadoras versus gestores) e uma ordem de valores (indivíduo versus pessoa).

\section{Improviso e Habitus Higienista}

A enfermagem no Brasil, como vimos, foi instituída como profissão durante a efervescência da Reforma Sanitária no início do século XX. Naquele período, a luta pelo desenvolvimento de uma saúde pública baseada na prevenção alavancou uma 
enorme discussão sobre a necessidade de investir em de uma educação sanitária da população. A participação de profissionais da saúde visitando domicílios e atuando como disseminadores de novas práticas corporais e de higiene, em acordo com os princípios da epidemiologia na qual a transmissibilidade das doenças constitui a realidade a ser considerada, foi percebida como o caminho para a popularização desse conjunto de conhecimentos e práticas.

O descontentamento das enfermeiras de alto padrão da Escola Anna Nery, ao se engajaram na saúde pública como visitadoras, incentivou a expansão de categorias técnicas que viriam a ocupar este lugar na saúde pública, ao mesmo tempo que a posição das enfermeiras era repensada, instaurando uma hierarquia específica ao campo da enfermagem entre graduados e não graduados.

No período atual de expansão das ações de saúde e saneamento por meio de projetos do governo como o Programa de Aceleração do Crescimento (PAC) e, mais especificamente no caso indígena, da implantação, em 1999, dos DSEIs em todo o país, esse grupo profissional se tornou estratégico para a concretização do modelo de assistência à saúde baseado na prevenção e educação em saúde. Essa situação guarda semelhanças com a fase inicial de expansão do projeto sanitário dos anos 1920, nos quais tais profissionais assumiram a tarefa de conscientização da população pobre sobre cuidados de saúde e, sobretudo, foi um período em que se constituíram vínculos indeléveis entre ações de saneamento, desenvolvimento nacional e autoridade pública (Hochman, 2006).

Os conceitos de busca ativa e promoção da saúde têm sido, nessa perspectiva, fartamente cultivados no discurso médico-sanitário recente, seja nos textos normativos das políticas do Sistema Único de Saúde (SUS), seja nos do Subsistema de Saúde Indígena, como mecanismos estratégicos de prevenção e de educação em saúde. Esses são dois conceitos complementares que constituem ações normativas consideradas essenciais ao desenvolvimento das políticas governamentais. O primeiro deles, busca ativa, se caracteriza como uma ação clássica de vigilância epidemiológica, sobretudo de doenças de notificação compulsória, mas que se expande para uma concepção de agir antecipadamente, tornando o improviso um valor para os atores engajados nesse processo. Já a promoção da saúde constitui em si mesma uma política nacional, atendendo a uma das principais estratégias do SUS, que é a de enfocar aspectos considerados determinantes para o processo saúde/adoecimento no país, dentre os quais se destaca a falta de saneamento básico (Brasil, 2006).

Esses conceitos sugerem a composição de certa base de orientações que poderiam ser pensadas no marco do higienismo surgido no século XX. Por higienismo entende-se um conjunto de práticas de higiene especificamente derivadas da biomedicina, e que são contrapostas a outras práticas de higiene existentes. Assim, higienismo refere-se a um corpo de conhecimentos e práticas, isto é, de um conceito-valor capaz de engendrar um habitus higienista pela maneira como 
tais ensinamentos sobre higiene são incorporados, compondo índices (visuais, táteis, olfativos) que permitem distinguir socialmente indivíduos ou grupos e que, no contexto de um atendimento culturalmente diferenciado, podem ensejar desconsideração sistemática por outras formas de classificação do que é sujo, limpo, puro ou impuro. Sugiro, assim, que os conceitos de busca ativa e promoção da saúde têm sido reapropriados como possibilidades legítimas de improviso, capazes de produzir relações em que a autoridade sanitária qualifica o discurso sobre o outro por meio de um nível capilar de atuação. É preciso, portanto, relacionar a importância do conceito de higiene para os profissionais da saúde sem perder de vista a sua contribuição ao tema do poder nas relações sociais. Especificamente, o sentimento de nojo e repulsa que parecem apontar para um "universo de natureza inquestionável" (Teixeira, 2012) tem consequências diretas sobre as concepções de um atendimento culturalmente diferenciado entre os profissionais da saúde que atuam no Subsistema de Saúde Indígena.

Nas atividades exercidas nos postos de saúde e, ao menos, em uma das Casas de Saúde Indígena do DSEI Rio Tapajós, o improviso constituía o cotidiano das técnicas de enfermagem em dois níveis: 1) em decorrência de constrangimentos materiais e humanos como falta de medicamentos, de pessoal, de insumos básicos como gazes, luvas, material de limpeza etc.; 2) como chave para entender a apropriação do termo atenção diferenciada pelos(as) técnicos(as) de enfermagem, utilizado como uma categoria nativa para elaborar a própria pertença social ao grupo de profissionais da saúde indígena.

Nas primeiras semanas de trabalho de campo, em um dos postos de saúde em uma aldeia distante duas horas de barco da cidade de Jacareacanga, o problema mais visível era a falta de equipamentos e insumos adequados e suficientes para realizar ações básicas, como limpar as instalações de atendimento, deslocar famílias com rapidez até hospitais, distribuir informações de maneira organizada, estabelecer diálogos consistentes durante o atendimento. Era também visível a falta de planejamento e pessoal que pudesse realizar todas essas atividades. Desse modo, mesmo sem levar em consideração os conflitos em torno de processos saúde-doença culturalmente diferenciados, os objetivos do próprio programa de atenção à saúde eram de difícil execução por parte da equipe. A significação desses elementos, percebidos como ausências graves por todos, ensejava a produção de práticas improvisadas por parte dos profissionais da saúde que serviam, ao mesmo tempo, para qualificar a diferenciação percebida na assistência básica à saúde indígena.

Assim, para os Munduruku não havia uma dimensão organizacional ou uma hierarquia de poderes pela qual suas vivências no processo saúde-doença pudessem ser reconhecidas no momento da busca pelo medicamento. Em vez disso, algumas palavras-chave em Munduruku eram cotidianamente usadas para comunicar sintomas como dor de cabeça, dor no peito e dor na barriga, por meio das quais as medicações básicas - anti-inflamatórios, antitérmicos e analgésicos - 
eram aplicadas. Essa simplificação da assistência no posto de saúde conformava uma via de mão dupla: tanto as técnicas quanto os Munduruku reduziam o tempo da interação em torno da obtenção do medicamento.

A situação é complexa, ou seja, não depende tão somente da boa vontade dos profissionais em tela, pois tal desconsideração do ponto de vista do outro tem raízes no processo de formação profissional do campo da biomedicina (Kleinman, 1988). O enquadramento do paciente em uma lógica tutelar, na qual certa hierarquia de poderes e certa ordem de valores se justificam mutuamente, aponta para uma realidade histórica do campo da saúde e com forte expressão no campo da enfermagem.

O debate sobre a tutela entre os profissionais da saúde tem se orientado em duas direções: estudos sobre a reforma psiquiátrica brasileira e uma nova concepção de abordagem às chamadas doenças mentais (Batista G Silva, 2009) e, com um foco bem distinto, a tutela tem recebido atenção dos enfermeiros como parte de um processo histórico de subjugação ao campo da medicina (Corbellini, 2007). Na perspectiva aqui apresentada, a lógica tutelar diz respeito ao exercício do cuidar cotidiano e suas implicações na relação com os doentes. Assim, busca-se compreender como essa premissa ontológica do campo da enfermagem, o cuidado, se associa a um possível mecanismo de desautorização do outro na perspectiva de uma gestão colonial das desigualdades (Souza Lima, 2002). ${ }^{9}$ Entende-se, portanto, que a lógica tutelar no campo da enfermagem permite um diálogo com o modelo da administração indigenista que compartilha alguns valores similares na relação historicamente construída entre patriotismo, abnegação e a premência de salvar vidas, mote tanto do discurso sanitarista quanto do discurso indigenista.

Assim, a lógica tutelar que permeia as relações entre políticas governamentais e povos indígenas tem como referência a indagação sobre a própria noção de políticas públicas, já que as políticas governamentais se constituem mediante diferentes modalidades de organização não necessariamente redutíveis à organização administrativa de estados nacionais imaginados (Souza Lima G Macedo e Castro, 2008). As etnografias realizadas em torno da administração pública/ indigenista demonstrariam haver uma pluralidade de associações que criam, produzem e conformam o que chamamos de Estado nacional com base em múltiplas relações e associações que compõem as políticas governamentais (Barroso-Hoffman, 2008; Corrêa, 2008). Da mesma forma, podemos estender esta mentalidade para o contexto de inserção das profissionais da enfermagem como agentes/atores desse universo de relações que constituem o governo. Por isso mesmo, a visão do Estado aqui adotada é necessariamente não linear. Como afirma Philip Abrams (1988), o que existe são práticas políticas, e a alegação de sua eficácia precisa ser metodologicamente questionada.

Uma situação etnográfica nos ajuda a refletir sobre tal sobreposição de lógicas tutelares oriundas de contextos históricos aproximados. A pesquisa de campo logrou desvelar que o ponto de vista de boa parte das técnicas de enfermagem sobre 
o atendimento "diferenciado" referia-se não aos Munduruku, mas a si mesmos. O que a princípio poderia parecer ilógico atende claramente a uma lógica interna ao grupo: são elas que, fixadas nos postos de saúde em aldeia pelo fluxo organizativo do Subsistema de Saúde Indígena - sem a presença de qualquer outro profissional da saúde, à exceção dos agentes indígenas de saúde -, consideram-se diferentes de quaisquer outros técnicos da área. São elas que, a despeito do medo e da denúncia consciente sobre a própria responsabilidade embutida nesse processo, se veem na situação de improvisar receitas, curativos, suturas, diálogos bilíngues; compartilhar experiências de dor e sofrimento alheios, para as quais não lhes é dada qualquer orientação formal. Era um relato unânime o de que o treinamento oferecido no DSEI se resumia a uma semana de explicações sobre o preenchimento do consolidado (relatório mensal das atividades cumpridas, preenchido em um modelo de formulário específico). Por isso, são profissionais que constituem seu valor por meio de um desempenho cotidiano, no nível micro do subsistema.

Por essas razões, o improviso surge como um valor, uma espécie de "jogo de cintura", expressão muito usada para dar vida à assistência básica nas aldeias. Certamente, o improviso poderia ser uma categoria negativa para descrever a precariedade material das condições de assistência produzidas no distrito. Mas o que importa aqui, ao se tentar esboçar um olhar atento sobre a perspectiva dessas profissionais, é que o improviso era vivido como um valor capaz de afirmar suas identidades diferenciadas e estabelecer profícuas relações com os Munduruku e com enfermeiras. É nesse sentido que o improviso assume um caráter de elogio social no interior do grupo. Ao pensarmos numa política de atenção diferenciada, temos que remeter tal critério de especialidade à experiência daqueles que são, na ponta do Subsistema de Saúde Indígena, responsáveis por essa articulação. Ao se tornarem profissionais da saúde indígena, elas próprias se percebiam como diferenciados.

É importante destacar que nenhuma dessas dimensões do improviso deve ser tomada isoladamente. O improviso era um conjunto de conhecimentos e práticas que organizava as relações e ações da equipe. O significado desses improvisos estava especialmente vinculado ao processo de diferenciação social por meio do qual participar da saúde indígena simbolizava uma pertença, isto é, uma ação positiva que orienta e produz subjetividades.

Desse modo, propõe-se destacar alguns momentos e situações rotineiras em relação ao cotidiano das famílias Munduruku nas aldeias, para analisar a relação entre o improviso como um valor que remete à constituição situacional e identitária de um grupo e o higienismo como prática legítima de um saber biomédico reapropriado contextualmente.

A cena mais comum ao cotidiano de atendimento das famílias Munduruku não eram, de certo modo, a distribuição de medicamentos, as campanhas de vacina- 
ção ou as palestras sobre transmissão de doenças. Sem dúvida, essa rotina existia e era fundamental para a lógica de organização dos serviços de saúde prestados. Entretanto, havia uma esfera mais fugaz, não relatada, não registrada nos protocolos ou consolidados e que tinha valor simbólico para as relações entre as profissionais da saúde e os Munduruku. Tais cenas poderiam ser mais bem descritas por meio de um habitus higienista incorporado como parte de um processo histórico amplo em nossa sociedade, e que correlaciona um sentimento de pertença social a certos comportamentos de higiene. Seria nosso agir civilizado, numa referência teórica clara à importância das práticas corporais na definição de hierarquias sociais (Elias, 1994).

A relação das técnicas em enfermagem com as famílias era guiada não apenas pela proximidade com as famílias Munduruku, mas por uma proximidade que pressupunha uma noção construída de busca ativa e promoção da saúde. Por um lado, a noção de busca ativa ensejava comportamentos como "bater de rede em rede" à procura de doentes; por outro, os critérios de promoção da saúde eram encarnados por essas profissionais como um saber-fazer próprio do agir civilizado e que era visto como de difícil domínio por parte dos indígenas. Esses deslizamentos de sentidos sobre conceitos normativos da saúde pública possibilitavam uma frequente desconsideração por outras formas de higiene e cuidados em saúde, que eram associadas à ausência de cuidados, e não à presença de uma alteridade.

$\mathrm{Na}$ aldeia, as conhecidas e proclamadas recomendações incluíam práticas corporais e cuidados com as crianças. A partir desse conhecimento incorporado, eram inseridos comentários discretos ao pé do ouvido sobre algum hábito de higiene, durante atendimentos rápidos no posto de saúde, reclamações genéricas a respeito das dificuldades de se trabalhar na saúde indígena - culpando as famílias por não colaborarem nas atividades - ou, ainda, recriminações e interpelações diretas que implicavam reorganizar a circulação das pessoas pela aldeia. Assim, as recomendações mais recorrentes eram evitar permanecer à beira do rio durante o amanhecer e o anoitecer, evitar ficar longos períodos debaixo do sol, evitar levar as crianças pequenas para a roça, não andar na chuva, não andar descalço, não beber água do rio, não defecar próximo à beira do rio. A amplitude e a capilaridade das formas comunicativas por meio das quais tais recomendações eram repetidas canalizavam mais ou menos o mesmo conteúdo: ações de promoção da saúde.

Pode-se certamente levantar uma série de dúvidas com relação à consistência de tais recomendações com referência ao cotidiano dos Munduruku, uma vez que se desconsidera, nesse processo, a relação de cuidado das famílias com suas crianças, sendo esta bastante complexa - envolvendo cuidados especiais com a alimentação nos primeiros dois anos de vida do bebê; a produção de pulseiras e colares com remédios tradicionais (Mukokaka'a e Wexiktak) para proteção contra os espíritos Axik que ameaçavam os recém-nascidos; ${ }^{10}$ idas regulares ao pajé para 
retirar feitiços no corpo; também idas regulares aos "massageadores" ou "puxadores" (Pikikpikik'ukat), que desmentiam casos falsos de feitiçaria; e ainda o uso de raízes específicas (Kanabu kokopkop) para o crescimento saudável das crianças.

Contudo, esses cuidados não eram reconhecidos como os cuidados para os quais as profissionais da saúde deveriam estar atentos ou com os quais deveriam dialogar. Ao contrário, a expectativa que havia sobre as famílias Munduruku era de que, ao primeiro sinal de melhora, deixavam de buscar a medicação e o tratamento no posto de saúde, como se isso significasse abandono de cuidados. A visível e importante participação do pajé na definição dos itinerários terapêuticos não era percebida como elemento de um mesmo universo de reabilitação e cura. Dessa configuração derivavam, então, os deslizamentos de sentido por meio dos quais se legitimava o uso de recursos improvisados, marcados pela percepção de que para trabalhar na saúde indígena era preciso "se virar nos trinta", "não se complicar", "ter jogo de cintura". Esses improvisos ganhavam um estatuto de valor identitário e uma posição social que articulava a lógica tutelar de desautorização do outro por meio da apropriação feita sobre os conceitos/práticas da busca ativa e da promoção da saúde.

O improviso não seria uma questão de habilidade cronológica ou da capacidade intelectual de tomar decisões rapidamente, como numa definição senso comum de emergência. Ao se improvisar, o que estava em jogo não era tão somente uma decisão tomada de maneira arbitrária e unilateral; ao contrário, poder improvisar qualificava os discursos e as relações entre os Munduruku e as profissionais da saúde. A especificidade desta análise antropológica dá-se no improviso como produção de subjetividades. Certamente, é importante refletir sobre a infraestrutura (remédios, barco, motor, combustível para luz e para barco etc.) como parte desse repertório do improviso - conforme descrito no parágrafo anterior - e que também configura experiências por meio das quais os sujeitos sociais criam e recriam práticas e formas de relação.

A positividade conceitual do improviso dentro da análise sobre a assistência à saúde indígena está em não reduzi-lo a um problema circunstancial. A habilidade para improvisar conferia acervo simbólico, capitaneado por um longo tempo de permanência nas aldeias, reforçando elementos de pertença ao grupo diferenciado da saúde indígena. O improviso qualificava a ambiguidade das ações em saúde, deixando espaços pelos quais a alteridade Munduruku era ressignificada.

Entretanto, analisando mais detidamente as trajetórias sociais do grupo de técnicas de enfermagem, é notório o uso de plantas medicinais caseiras como um meio de cura legítimo e popular. É relevante que as experiências nas quais essas pessoas eram formadas e formadoras produziam cenários híbridos (não no sentido da produção de um terceiro tipo de conhecimento), que orientavam as ações improvisadas. Por isso, tais ações não reproduziam os esquemas de representação oriundos do olhar comparativo entre sistemas médicos, como por muito tempo foi 
discutido na antropologia médica norte-americana (Kleinman, 1980, 1988). Embora o higienismo seja um conjunto de conhecimentos derivado da biomedicina, sua principal característica é a de ser uma técnica do corpo, um habitus (Mauss, 2003).

Assim, cabe perceber a ambiguidade - termo muito usado para falar das experiências dos agentes indígenas de saúde (Erthal, 2003; Dias-Scopel, 2005; Novo, 2010) - como constructo social plenamente integrado à história de construção do campo da enfermagem. Desse modo, ao utilizar noções específicas, tais como as noções de habitus higienista e improviso e a lógica tutelar que os sustenta, destaca-se a conjunção de uma ordem de valores (biomedicina, conhecimentos populares e conhecimentos indígenas) com uma hierarquia de poderes (dimensão organizacional) que divide tarefas, e cujas prerrogativas de atuação se desenrolavam num efeito cascata que se iniciava na enfermeira até a figura do agente indígena de saúde. Se, por um lado, tal procedimento ajudou a desconstruir uma perspectiva meramente normativa dos cuidados em saúde (dever-ser da política pública), por outro tornou possível explicitar os pontos de vista das profissionais da saúde cotidianamente comprometidos com critérios de busca ativa e promoção da saúde, por meio dos quais foi possível mapear não apenas os deslizamentos de sentido, mas sua dinâmica social.

A desconsideração sistemática do conjunto de conhecimentos e práticas dos Munduruku em relação à saúde de suas crianças e da comunidade como um todo fazia parte desse repertório de improviso - isto é, o teor das ações de promoção da saúde só atingia sua eficácia ao reproduzir atitudes higienistas, ensejando uma inevitável (e inconsciente) lógica tutelar segundo a qual se justificavam e se naturalizavam práticas de uma autoridade não coercitiva, cuja principal forma de atuação é a benevolência. Tais formas de tratamento que desconsideram o outro, em virtude da própria diferença étnica, articulavam a lógica tutelar historicamente imposta aos doentes à lógica tutelar oriunda do estereótipo do ser indígena em nossa sociedade. Assim, se há algo que une esses contextos no qual a tutela se reinventa, é a ambiguidade constitutiva de uma autoridade benevolente, que não se impõe como força coercitiva, mas como modelo ideal de relação.

Se na dimensão do improviso se naturalizava certa percepção sobre os cuidados de saúde entre os Munduruku, quando entramos na seara das enfermeiras essa percepção encontra sua máxima expressão. A disputa em torno da concepção de cuidado é central e produtora de constantes ambiguidades, apontando para a multiplicidade de apropriações sobre o cuidado no campo da enfermagem. Pretende-se, a seguir, discutir a relação entre a lógica tutelar e as noções de cuidado com base no ponto de vista de duas enfermeiras, com atitudes que, pela divergência apresentada em relação à assistência prestada aos Munduruku, se tornaram representativas da produção de ambiguidades nesse campo. 


\section{Autoridade Benevolente, Produção de Indiferença e a Lógica Tutelar: cuidar e gerir}

Se para o grupo de técnicas o improviso se constituía como um valor que as identificava como profissionais da saúde indígena - capaz de converter a própria noção de atenção culturalmente diferenciada em um mecanismo de distinção interno às relações entre profissionais no campo da saúde -, para as enfermeiras eram os cuidados de enfermagem, teórica e disciplinarmente concebidos como formas de relação com o outro, que construíam suas identidades. Os cuidados de enfermagem eram mais que um arsenal de orientações. A forma de organização dos serviços, a formalização de hierarquias, a relação instituída com os doentes e suas famílias eram, por excelência, os elementos em disputa desse cuidar. O cuidado simbolizava, a um só tempo, um conceito de ação em saúde e uma forma de atuar em relação à alteridade Munduruku.

No âmbito deste capítulo, serão discutidos dados etnográficos relativos ao grupo de enfermeiras da mesma forma que foi feito com o grupo de técnicas de enfermagem: buscando uma categoria nativa capaz de significar aspectos da relação. O cuidado como um valor constitutivo da autoridade/identidade no campo da enfermagem possibilita analisar a constituição das estratégias de benevolência como elemento formal das ações de cuidados em saúde, seja em palestras, seja em atividades de prevenção. Nos próximos parágrafos, serão descritas situações referentes a Malu e Silvana, ${ }^{11}$ duas enfermeiras cujos distintos modos de conceber e praticar cuidados de enfermagem permitem sugerir uma análise da ambiguidade entre cuidar e gerir no contexto de uma assistência em saúde culturalmente diferenciada.

O cotidiano do posto de saúde era marcado pela rotina da distribuição de medicamentos. Consultas para males como dores de cabeça e de estômago, queixa muito comum entre os adultos, eram situações residuais de atendimento. Sempre havia quatro ou cinco adultos em tratamentos desse tipo, mas o número de crianças era muito superior, a ponto de dominar a rotina do posto. Também é possível associar a isso uma frequência significativa de mulheres, de variadas faixas etárias, acompanhando seus filhos, netos ou irmãos em busca de medicações contra problemas respiratórios, diarreias e verminoses.

\section{Autoridade benevolente}

Malu apresentava um longo histórico de trabalho no DSEI, sendo contratada desde 2000. Essa experiência era valorizada coletivamente entre as enfermeiras - e, neste caso, uma especialização em enfermagem obstétrica lhe conferia uma proximidade extra nos cuidados com as crianças. Ela fazia ausculta nos que apresentavam tosse e usava o discurso de prevenção contra a pneumonia no caso 
dos menores de 5 anos; sua preocupação girava em torno da percepção de que as crianças indígenas eram mais vulneráveis à gripe e a processos de infecção respiratória. Havia uma noção generalizada entre as profissionais da saúde - pude ouvir este argumento nas mais variadas ocasiões - de que os corpos indígenas eram mais frágeis às doenças dos brancos, sobretudo em relação à gripe e à pneumonia. Apesar de não saber explicar como isso era possível do ponto de vista da biomedicina, Malu expressara inúmeras vezes essa percepção que considerava elucidativa para se trabalhar com saúde indígena. A malária era outra doença com a qual a enfermeira manifestava preocupação constante, mas por motivos distintos. Tratava-se, nesse caso, de convencer o paciente a realizar o tratamento completo, já que a malária é uma enfermidade originalmente associada às terras baixas sul-americanas e considerada endêmica na região. Por esta razão antecipada, Malu realizava exames das amostras de sangue com o microscopista do posto de saúde em todos os pacientes com febre alta.

Ela não perguntava aos pacientes por sintomas, mas buscava examinar o corpo das pessoas diretamente, olhando a língua, palpando os rostos, verificando a pele e os olhos. Assim, anunciava uma previsão de diagnóstico, seguida de recomendações como a que deu a respeito da gripe nas crianças. Não havia um diálogo propriamente dito, e Malu jamais se sentava à mesa da sala de atendimento; estava sempre andando, circulando, e atendia as pessoas na antessala onde havia bancos de madeira ou diretamente nas casas, quando era solicitada. A construção da relação de cuidado com o olhar treinado pela formação disciplinar (Foucault, 2004)12 era habitual nas intervenções da enfermeira. Essa prática agregava um sentido de autoridade, marcando sua posição hierárquica como coordenadora dos serviços prestados pela EMSI nas aldeias.

Em torno dessa noção de autoridade, uma situação comum ao atendimento era a produção de constantes acusações em torno dos cuidados com as crianças. Desde o nascimento até a idade de 5 anos, as crianças eram acompanhadas por uma pesagem mensal, quando eram feitas avaliações sobre seu desenvolvimento e crescimento. Por meio desse procedimento, a enfermeira relatava diversas reclamações sobre os cuidados materno-infantis e, especificamente, sobre a conduta das mães. Essas práticas discursivas apareciam diretamente associadas à questão de gerir os programas de saúde e prestar assistência, fazendo o sentido do cuidado reificar certo estereótipo sobre os Munduruku naquele contexto: o de que não eram capazes de compreender a dinâmica dos cuidados a serem observados. Tais informações, entretanto, nunca eram explicadas exaustivamente, pois constituíam um conteúdo valorizado cujo acesso era interditado. Na maioria das vezes, a enfermeira apenas recriminava um comportamento ou outro. Os diálogos eram reduzidos, e pode-se supor que essa redução do diálogo tem a ver tanto com dificuldades linguísticas quanto com a disputa por um acervo simbólico que não deveria 
ser publicizado. Entretanto, essa prática também estava permeada por uma lógica tutelar já conhecida e naturalizada pelas enfermeiras e que, no caso em tela, torna a análise mais complexa. Afinal, é preciso levar em consideração essa confluência de uma perspectiva mais abrangente, oriunda do campo da enfermagem, com o contexto específico configurado pela assistência a povos indígenas no Brasil, cujos estereótipos de vulnerabilidade atravessam a relação com o campo da enfermagem, mas nem de longe se esgotam nele.

Segundo a enfermeira, a história de sua chegada àquele polo-base fora motivada pela mortalidade infantil. A aldeia teria enfrentado um número alarmante de óbitos entre crianças de zero a 5 anos, em torno de vinte, durante a passagem da última enfermeira, já desligada do DSEI. Tal situação teria motivado a coordenadora na época a deslocar para a aldeia uma enfermeira "mais experiente", que pudesse diminuir esse índice. Malu contava com orgulho que desde o início de seu trabalho a única criança que morreu fora atingida acidentalmente por um raio. Tal forma de assistência, marcada pelo discurso da intimidade sobre a realidade das famílias Munduruku e sobre as histórias que a enfermeira acompanhava pessoalmente, constituía a própria identidade de Malu. Esse cuidar engajado no cotidiano da aldeia era usado como repertório por meio do qual ela buscava se diferenciar de outras profissionais da enfermagem, constituindo uma competência que extrapolava a do método clínico. Por vezes, tal percepção de domínio sobre os problemas da aldeia ensejavam práticas de desautorização do outro que eram legitimadas pela própria noção de cuidado. O mecanismo da benevolência deve ser entendido, dessa forma, como síntese da ordem de valores higienista e do exercício de uma posição de poder no campo da enfermagem.

Um evento significativo para a compreensão dessa lógica de ação será útil para elaborar a perspectiva da autoridade benevolente. Certa vez, Malu trouxe até a casa anexa ao posto um bebê de um ano e meio que havia ficado internado por cinco meses em Itaituba (PA), fazendo tratamento contra desnutrição, e fora um dos primeiros casos graves dos quais cuidou quando assumiu aquele polo-base em 2007. Malu me pediu para segurar o bebê enquanto lhe preparava um banho e um mingau. A menina usava um vestido amarelo com bordados. Malu enfatizou seu aumento de peso. A enfermeira demonstrava estar feliz pela recuperação da criança e, enquanto lhe dava banho, me pediu que tirasse uma foto daquela cena para seu arquivo pessoal. Entretanto, para Malu o problema do bebê era familiar; ela afirmou que "a mulher que a pegara para criar" era mãe recente de outra criança e não estava conseguindo amamentar um segundo bebê. Reclamou, ainda, das condições anti-higiênicas em que encontrara a criança na casa da família. Cerca de meia hora depois, a mãe apareceu para buscar a criança e o vestido que Malu havia se esquecido de recolocar no bebê. Após esse episódio, o caso da meniṇa com desnutrição jamais voltou a ser mencionado pela enfermeira. 
Não era difícil supor que minha presença nesse campo de tantas clivagens hierárquicas tivesse configurado um momento único para que tanto Malu quanto Silvana pudessem expor os resultados obtidos nessa empreitada.

Certamente, o exercício de interlocução experimentado durante a pesquisa de campo com as enfermeiras era tenso pelo excesso de expectativas acumuladas diante de toda sorte de problemas infraestruturais, mas ao mesmo tempo pressupunha uma (às vezes, a única) oportunidade de externar não apenas problemas de ordem material (lugar-comum para qualquer profissional da saúde indígena), mas, sobretudo, seus dilemas fundamentais no campo da enfermagem. Foi nesse sentido que os discursos de Malu e Silvana se atravessam, mostrando concepções distintas sobre a conduta ideal da enfermeira.

\section{Produção de indiferença}

Silvana era uma enfermeira recém-formada por uma universidade pública e recém-contratada pelo DSEI. Antes de ser designada para aquela aldeia, havia trabalhado por oito meses num polo-base mais distante da cidade. Bastante ciente de sua conduta profissional, elaborava muitas críticas ao comportamento de enfermeiras "mais antigas" como Malu. A principal fonte de divergência era a própria definição de cuidados de enfermagem. Silvana postulava que qualquer envolvimento além do protocolo das consultas era totalmente inadequado, enquanto Malu valorizava justamente essa dimensão da experiência nas aldeias para se atribuir valor e credibilidade ante os pares profissionais. Nenhuma das duas formas de relação, é importante lembrar, excluía o que denominei anteriormente de práticas de autoridade benevolente. Contudo, explicitar essas nuanças sobre as diferenças que os próprios sujeitos manifestam e expressam sobre suas ações e as ações dos outros é o que constitui o cerne de uma análise antropológica participativa nos termos de Langdon e Garnelo (2004).

Durante os meses em que a enfermeira Silvana esteve atuando no posto de saúde, acompanhei suas atividades, incluindo reorganização dos arquivos do posto e as consultas. Destaca-se, dentre diversas situações observadas, um caso típico de conflito e confusão no atendimento aos Munduruku. O senhor Mateus Karo, ${ }^{13}$ de mais ou menos 60 anos, apareceu no posto reclamando de pontadas no peito e dores de cabeça. A agente indígena de saúde Teresa mediu sua pressão arterial e confirmou que ele era hipertenso e que seus remédios haviam acabado. Foi-lhe entregue medicação para um mês. Teresa trouxe, então, um documento para a enfermeira verificar. Era uma solicitação de consulta em Belém para alguém chamado Mateus Waro. Silvana reparou que o sobrenome do paciente estava trocado. Depois, percebeu que Waro e Karo eram nomes existentes, mas que se confundiam com frequência nas anotações das profissionais da saúde. Como Teresa 
informou que não havia ninguém do clã Waro na aldeia, chegou-se à ideia de que aquela solicitação podia ser mesmo para seu Mateus Karo, mas restava a dúvida. Imaginando que poderia ser ele, seu Mateus relatou que já havia ficado internado em Belém e que as profissionais da saúde daquela Casa de Saúde Indígena costumavam perguntar aos próprios pacientes por que eles haviam sido enviados para lá com "aquele tipo de problema". Seu Mateus concluiu que se era para ficar longe de sua família e sem nenhum apoio, ele não queria ir.

A descrição de seu Mateus era precisa e muito importante no contexto do diálogo. O sofrimento contido na descrição da experiência de se internar na Casa de Saúde Indígena não fazia parte, contudo, da maneira como a enfermeira enquadrava a necessidade e a urgência dos pacientes. Assim, no momento do diálogo, Silvana não deu importância a essa reclamação e não ofereceu qualquer tipo de retorno ao problema concreto apresentado pelo seu Mateus. O senhor parecia desanimado e repetiu que não iria, independentemente da conclusão a que se chegasse sobre o paciente da solicitação. Não se tratava aqui somente da construção de significados sobre o processo saúde-doença, mas também de um conflito social com base nas relações de poder estabelecidas com os profissionais da saúde graduados. A recusa do paciente era vivida como um problema exterior a esse universo dialógico, que quanto mais enclausurado em si mesmo mais fictício se tornava para as pessoas, desconsiderando os elementos cotidianos do adoecer.

O tipo de autoridade que o universo da consulta indexava de maneira eficaz era capaz de converter arbitrariedade em necessidade, como nos processos burocráticos analisados por Herzfeld (1992). Assumindo tal perspectiva teórica, qual seja, a de que a dimensão organizacional produz significados e constrói relações de poder, pode-se ver a eficácia do trabalho de Silvana, que, por exemplo, montara uma escala de trabalho para os AISs, com folgas alternadas de fins de semana. $\mathrm{Na}$ escala, cada AIS deveria fazer oito visitas diárias e anotar as informações dos pacientes segundo os programas de saúde que estava reorganizando: os hipertensos e diabéticos (conhecidos no jargão profissional como "hiperdia"), crescimento e desenvolvimento de crianças de 0 a 5 anos (CD), e o Programa de Prevenção ao Câncer do Colo do Útero (PCCU).

Foi por meio da reorganização do espaço físico do posto, de seus arquivos e da escala dos AISs que a enfermeira me apresentou cerimoniosamente seu trabalho. Esse era o parâmetro usado por Silvana ao reconhecer um bom trabalho de enfermagem: arquivos classificados, programas de saúde com informações atualizadas, consultas de enfermagem relacionadas aos programas a serem desenvolvidos e administração do pessoal de apoio, isto é, técnicas de enfermagem e agentes indígenas de saúde. Essa forma de atuar implicava certa relação diária com os doentes na qual a ideia de adesão aos programas de saúde não era problematizada, mas se naturalizava nessa demanda administrativa que Silvana considerava prioritária nas 
atividades de enfermagem que cabiam às enfermeiras. Desse modo, a gestão da saúde no âmbito da aldeia excluía, a princípio, qualquer possibilidade de mediação de saberes ou práticas, uma vez que o diálogo estabelecido pela enfermeira pressupunha uma total adesão às formas de atendimento oferecidas. A não adesão era reconhecida como falta de cuidado de si, evidenciando a dificuldade de reconhecer outra noção de pessoa - distinta daquela na qual o indivíduo é o valor central a orientar as percepções sobre o cuidado.

Sem reconhecer essa diferença, tudo se passava como se o modo de vida Munduruku fosse a causa dos maus indicadores de saúde conhecidos (alta incidência de mortes por problemas respiratórios, por exemplo), deslegitimando tal modo de vida (suas escolhas, seus argumentos, suas opiniões) e o tornando mera consequência de condições de vida precárias que, ao fim e ao cabo, nem eram nominadas pela enfermeira. Esse não nomear indica uma confusão necessária entre modos de vida, como uma escolha culturalmente informada, e condições de vida (externalidades: falta de saneamento, coleta regular de lixo etc.), como se as condições determinassem os modos. A flagrante demora na instalação de uma bomba d'água para a população da aldeia, por exemplo, que se prolongou por dez anos até que as pessoas pudessem utilizar as já velhas torneiras instaladas em suas casas, nunca fora comentada por Silvana. Esse era certamente um caso típico da falta de condições de vida, mas que foi traduzida em condutas individuais como a falta de higiene e cuidado de si. O perfil epidemiológico se inseria numa economia moral e o uso de categorias desse universo semântico, como cuidar e gerir, adquiria sentidos locais sentidos estes que ultrapassavam uma dimensão normativa e descreviam relações de poder mais amplas, associadas a estereótipos construídos por ambos os lados.

Na dinâmica de suas consultas, principal forma de relação com os Munduruku para Silvana - que se recusava a deixar as dependências do posto de saúde quando estava na aldeia -, o modelo clássico da consulta médica era fundamental. Após perguntar como o paciente estava se sentindo, com a ajuda do AIS, ela usava os instrumentos disponíveis para atender: termômetro, aparelho de pressão arterial e estetoscópio. Concluída a etapa de examinação, ela anotava o medicamento a ser ministrado num pedacinho de papel, entregava ao AIS, que repassava às técnicas de enfermagem na sala ao lado, onde as medicações eram distribuídas nos horários fixados. Essa sequência, mais do que uma rotina de trabalho, tinha uma força ilocucionária (Austin, 1990) por meio da qual sua legitimidade era construída. O cuidado de enfermagem, portanto, passava necessariamente pelo distanciamento do sofrimento dos doentes como forma de gerir a assistência prestada - isto é, o sofrimento era tratado como algo de âmbito estritamente pessoal e subjetivo, longe do olhar clínico.

Gostaria de fazer alusão a certo tipo de lógica presente na formação disciplinar das ciências da biomedicina, classificando esse modo de agir dentro de 
um escopo histórico e cultural mais amplo. O dilema apresentado às enfermeiras se assemelha à ambiguidade entre caring e competence (Good G Good, 1993)14 nos estudos etnográficos sobre a formação médica anglo-saxã nos Estados Unidos, formação essa com forte influência em nossas escolas, como foi visto na digressão sobre o surgimento da figura das enfermeiras de alto padrão durante a reforma sanitarista.

Byron Good e Mary-Jo Good (1993) alertam, com relação à ambiguidade entre caring e competence, que os movimentos de humanização na saúde, ao reincidirem sobre a dita dicotomia para explicar o processo de desumanização dos médicos, terminam por reificá-la, validando o sentido da competência como um terreno da reflexão científica em oposição à humanização, como um terreno de reflexão das humanidades. A intenção de discorrer sobre a ambiguidade entre caring e competence, ou entre cuidar e gerir, insere-se na tentativa de descrever certa economia moral, compreendendo uma ordem de valores em sua extensão cotidiana. Refiro-me, especialmente, à ideia de sensibilização dos profissionais da saúde, que parece endossar a perspectiva dicotômica da formação disciplinar anglo-saxã. É nesse sentido que Good e Good (1993: 94) elaboram sua análise etnográfica do "processo de reconstrução da pessoa como um objeto do olhar médico".

\section{Cuidar e gerir: continuidades e rupturas do campo da enfermagem na saúde indígena}

Retomando o problema central deste capítulo, perfizemos uma trajetória que se inicia na instauração de um tempo mítico na saúde pública brasileira com sua proposta de educação em saúde como forma de inclusão social - por meio do legado pioneiro de Anna Nery - até as experiências cotidianas de técnicas e enfermeiras em aldeias indígenas do DSEI Rio Tapajós. A principal linha de continuidade entre esses dois cenários foi construída por meio de etnografia que logrou destacar uma ambiguidade constitutiva do campo da enfermagem no Brasil - entre cuidar e gerir. Por um lado, foi possível compreender a dinâmica do improviso como um elogio e um recurso estrito senso (e não como um conceito que remete à ausência de recursos), cujo relevo social já vinha sendo construído desde as campanhas das enfermeiras-visitadoras no início do século XX. Por outro lado, a noção de cuidado aparece como uma síntese da tensão entre cuidar e gerir - tensão essa muitas vezes vivida como se fossem características individuais de profissionais específicos, mas cuja dimensão se estende à própria formação disciplinar de enfermeiras e enfermeiros e ao contexto político de produção de cidadania e identificação com a nação via ações de saneamento. 
$\mathrm{Na}$ apresentação dos dados do trabalho de campo realizado entre 2008 e 2009, o foco esteve nos diálogos entre as profissionais da enfermagem e os Munduruku. Tais diálogos remeteram, simultaneamente, à perspectiva sanitarista das campanhas de saúde pública - em que as noções de busca ativa e promoção à saúde ganharam os contornos de uma diária conscientização por bons modos de higiene e assepsia - e à perspectiva tutelar, desmembrada em dois contextos de produção de significados: a benevolência das ações para resguardar a vida e o corpo vulnerável dos índios e a indiferença da produção dos índices de saúde.

Tratar tais dimensões como opostas, entretanto, foi uma consequência direta do modo como as profissionais da enfermagem compreendiam suas tarefas e organizavam cotidianamente suas ações. Em termos da análise teórica a que esses dados remetem, chama a atenção o quanto essa ambiguidade é eficaz em replicar uma hierarquia de poderes no campo da saúde pública por meio da ritualização dessa oposição de valores nas diversas esferas da ação cotidiana. Mais do que a centralidade do olhar clínico, a disputa pelo significado da experiência nas aldeias se constituía para as enfermeiras como um elemento indispensável ao acervo simbólico que as identificava com esse nicho de atuação, construindo suas competências próprias: seja pela ênfase na organização dos programas de saúde e arquivos, representada pelo caso de Silvana; seja pelos atendimentos em casa e os cuidados focados numa certa parcela da população, representados pelo caso de Malu; seja pelo elogio ao improviso, caso geral das técnicas de enfermagem.

A falta de formação específica das enfermeiras na atuação com povos indígenas certamente salta aos olhos nesta discussão. Nesse sentido, procurou-se mostrar o quanto as duas enfermeiras se consideravam experientes sobre o tema, explicitando suas razões para tanto. Malu dava destaque às ações de assistência direta. Uma de suas afirmações mais enfáticas era a de que odiava escrever e que "se dependesse disso para viver, morria!". Se Malu não valorizava o ato de registrar, é interessante notar quais outros aspectos eram considerados importantes e percebidos como opostos a esse. Se a gerência dos enfermos apontava para uma forma de assistência legítima, as relações de cuidado internalizadas como um mecanismo de autoridade benevolente legitimavam uma contraposição a um perfil burocrata, mas que é também responsável pela legitimidade científica da formação do enfermeiro. Pelo menos é isso que sugerem os estudos sobre a histórica da enfermagem e da construção da formação profissional das enfermeiras durante a Reforma Sanitária, e para a qual a imagem icônica de Anna Nery contribui grandemente (ver nota 8, em que se transcreve trecho de um discurso de Chagas dirigindo um apelo às mulheres brasileiras para aderirem à carreira na saúde pública).

Focada na prestação de assistência direta, Malu jamais se negava a fazer visitas quando era solicitada. As visitas eram uma forma de interação esperada pelas famílias, assim como a circulação pela aldeia; por isso, guardavam um sentido 
totalizante na construção da identidade cuidadora: em seu polo-base nenhuma criança havia morrido. Era nesse sentido primordialmente que as visitas eram enquadradas, conferindo um estatuto de experiência e uma noção de intimidade como forma de autoridade.

Em contrapartida, as acusações sobre a falta de cuidados de si que a enfermeira Silvana efetuava eram sempre genéricas e enunciadas como um hábito dos Munduruku em geral, de uma comunidade inteira, ou ainda um problema de fora da aldeia e sem possibilidade de solução localizada: eram as condições de vida precárias que se traduziam pela universalidade do discurso da falta de educação em saúde. Por outro lado, Malu apontava as pessoas ou atitudes que reprovava e o motivo. A forma da relação era a do engajamento explícito, a ponto de estabelecer desavenças circunstanciais e pontuais entre os Munduruku e entre as profissionais da saúde ao mesmo tempo, uma vez que seu grau de envolvimento nas questões de saúde do município e das aldeias lhe permitia essa dupla inserção. No caso de Malu, claramente se construía o valor da experiência na saúde indígena e a competência de saber-fazer centralizando em sua persona as habilidades para tal.

No Quadro 1, podemos visualizar esses diferenciais na escala de valores associados ao cuidado para compreender o exercício de uma autoridade cuja forma de poder não pode ser descrita normativamente. Constituído por uma ação capilar, cuja principal característica era a de que não havia um conteúdo fixo ao qual o exercício desse poder se ligava, o cuidado era um valor que interligava as ações na enfermagem e que, como visto, explicitava visões distintas da experiência de viver na aldeia. Essas visões são representativas de uma ambiguidade que transcende a experiência individual. Nesse sentido, a conexão com os apelos de Carlos Chagas às enfermeiras-visitadoras da reforma sanitarista não passa despercebida: Anna Nery se torna símbolo da enfermagem por um duplo vínculo - como mãe dos brasileiros e suas habilidades naturais para cuidar e como contemporânea de Nithingale, tornando eficaz a utilização de sua imagem na construção das ações de saneamento e de suas premissas gerenciais.

O valor da etnografia atinge seu potencial teórico ao conseguirmos, por meio dela, realizar a passagem entre indivíduo e sociedade apontando para constructos sociais amplos e historicamente datados como referência para ações individuais que, muitas vezes, são vividas no mais profundo estado de solidão (refiro-me às numerosas queixas de diversos profissionais de enfermagem ao permanecerem sozinhos nas aldeias por ocasião das escalas alternadas de trabalho). 
Desse modo, chegamos a uma espécie de quadro de oposições que pode ser assim visualizado:

Quadro 1 - Valores do cuidar e do gerir

\begin{tabular}{|l|l|}
\hline \multicolumn{1}{|c|}{ Cuidar } & \multicolumn{1}{c|}{ Gerir } \\
\hline $\begin{array}{l}\text { Fazer visitas em casa e atender às chamadas das } \\
\text { famílias em domicílio. }\end{array}$ & $\begin{array}{l}\text { Pedir às pessoas para irem ao posto de saúde, restringir } \\
\text { horários de atendimento com base no expediente do } \\
\text { posto de saúde. }\end{array}$ \\
\hline $\begin{array}{l}\text { Olhar clínico para problemas não anunciados } \\
\text { pelos próprios pacientes (antecipação). } \\
\begin{array}{l}\text { Circulação intensa pela aldeia e pelas casas, } \\
\text { buscando doentes e problemas não relatados. }\end{array}\end{array}$ & $\begin{array}{l}\text { Atualizar os arquivos dos programas de saúde, prestar } \\
\text { consultas de enfermagem no espaço do posto de saúde. }\end{array}$ \\
\hline $\begin{array}{l}\text { Negociar decisões difíceis com o cacique (em } \\
\text { geral, envolvendo deslocamento para a cidade e } \\
\text { recusa de atendimento). Trocar alimentos com } \\
\text { os Munduruku frequentemente. }\end{array}$ & $\begin{array}{l}\text { Não se envolver no universo de relações na aldeia, } \\
\text { escrever os relatórios consolidados em dia, manter-se } \\
\text { nos limites físicos do posto de saúde, não trocar } \\
\text { alimentos com os Munduruku. }\end{array}$ \\
\hline $\begin{array}{l}\text { Fazer reclamações diretas aos Munduruku } \\
\text { sobre comportamentos considerados de risco, } \\
\text { prescindindo do espaço institucional da palestra } \\
\text { em saúde. }\end{array}$ & $\begin{array}{l}\text { Efetuar reclamações aos superiores imediatos, } \\
\text { apontando problemas via relatório consolidado } \\
\text { mensal. Valorização do espaço do posto de saúde e das } \\
\text { palestras como único espaço de interlocução com os } \\
\text { Munduruku. }\end{array}$ \\
\hline
\end{tabular}

Buscar valorar a melhor atuação seria propriamente um equívoco nos termos da abordagem teórica escolhida. Inserindo esses conteúdos em uma teoria da prática, como a de Bourdieu (2009), é possível compreender o mecanismo de atuações, tentando tecer comparações mais abrangentes com outras formas de poder historicamente relacionadas às práticas da administração pública entre os povos indígenas. No caso das enfermeiras, a noção prática de cuidados de enfermagem incapacitava o outro por meio da imposição de um olhar sobre as doenças em relação aos Munduruku, podendo, sim, fazer uso das classificações da biomedicina para tal, mas usando outros dispositivos socialmente relevantes provenientes da organização social e familiar, como as acusações em torno da relação entre mãe e filho - situada no polo do cuidar - e o cuidado de si - situado no polo do gerir.

A lógica tutelar no campo da enfermagem - seja pela via da indiferença burocrática, seja pela via da autoridade benevolente - permite um diálogo com o modelo da administração indigenista que compartilha alguns valores similares na relação historicamente construída entre patriotismo, abnegação e a premência de salvar vidas, ${ }^{15}$ premissas também identificadas no discurso sanitarista.

Ao eleger as categorias nativas do improviso e do cuidado para compreender os conflitos cotidianos na assistência à saúde indígena, o intuito foi produzir 
uma etnografia dos fazeres biomédicos. Tais fazeres, certamente, não se dissociam dos saberes biomédicos. Entretanto, no debate marcado pela referência crítica a tais saberes, têm-se produzido análises generalizantes sobre o ponto de vista dos profissionais da saúde. A prática destes em relação aos povos indígenas vem-se mostrando contraditória e plena de significações que cambiam contextualmente, como mostram diversas etnografias produzidas na última década (Garnelo, 2003; Garnelo G Sampaio, 2003; Marques, 2003; Chaves, Cardoso G Almeida, 2006; Langdon et al., 2006; Magalhães, 2006; Novo, 2010). A relevância da tensão dual entre cuidar e gerir no campo da enfermagem oferece um bom caminho para refletir sobre tais dissensos com base nas relações sociais que se produzem na esfera cotidiana da assistência à saúde indígena.

Nesse sentido, a abordagem simmeliana do conflito como sociação, em vez de ausência de relação, possibilitou explorar as categorias surgidas por meio do trabalho de campo. O improviso, como forma de relação e valor identitário de um grupo, permitiu que a leitura da participação das técnicas de enfermagem fosse além da reprodução de polaridades como biomedicina e medicinas indígenas. Ao contrário, a percepção de que a atenção diferenciada estava relacionada às suas condições específicas de trabalho nas aldeias se tornou um dado de referência para repensar esse esquema de análise entre profissionais da saúde sem formação superior.

Já o cuidado, como símbolo de uma profissão socialmente associada a valores centrais da tutela como abnegação e voluntarismo, se tornou importante para compreender as tensões duais no campo da enfermagem e sua expansão para a saúde indígena por meio da sobreposição de lógicas tutelares.

Ao falar em campo da saúde indígena neste capítulo, busquei enfatizar uma diversidade pouco reconhecida nesse contexto tão marcado pela tensão dualista entre biomedicina e medicinas indígenas. A percepção de que o Estado não é um ente externo (Abrams, 1988), apesar de não ter sido extensivamente tratada no âmbito deste texto, não deixou de ser um ponto de partida para compreender a complexidade nas ações dos sujeitos engajados na oferta de assistência aos povos indígenas. Se o Estado não existe acima ou fora das práticas políticas, seria importante poder replicar tal raciocínio também ao olhar para o Subsistema de Saúde Indígena. Entre tais práticas, revelou-se que a ordem de valores operante entre os sujeitos categorizava os profissionais da biomedicina como detentores de um conhecimento nem sempre eficaz, nos termos das próprias profissionais da saúde, mas certamente valorizado e vivido como aporte inquestionável para o processo de tomada de decisões.

O dualismo entre cuidar e gerir é a leitura preferencial de um ponto de vista biomédico, baseado no fisicalismo, que se corre o risco de reproduzir ao analisar a prática das profissionais da saúde. Mas se suas ações desvelaram mecanismos de uma autoridade benevolente e a subsequente exclusão das agências indígenas, tais 
situações ou índices não podem ser analisados tão somente pela ignorância sobre as teorias Munduruku em torno da causalidade das doenças. Antes, as práticas mais comuns eram a valorização e a explicitação de experiências pessoais entre os Munduruku, vivendo nas aldeias por longos períodos e anunciando uma intimidade que os diferenciava socialmente dos seus pares que atuavam na cidade. A perspectiva que orientava essa valorização de ser profissional da saúde indígena era a mesma que, em outros momentos, deixava entrever a desconsideração e o desrespeito por concepções outras de cuidado como as que seu Mateus Karo conseguiu explicitar na consulta com Silvana.

A lógica tutelar no contexto da saúde indígena deve ser relacionada, portanto, ao histórico de formação de profissionais da enfermagem associado, por sua vez, ao contexto de produção de habilidades em saúde indígena. O mecanismo da tutela se realizava em certas práticas de cuidado que, em nome da especificidade cultural, naturalizavam a ignorância do outro sobre a causalidade das doenças como a de um paciente típico cuja única diferença é a de ser biologicamente mais vulnerável a certos tipos de doenças. Parece, então, que a construção social da indiferença sobre os modelos de reabilitação e cura indígena estaria ocorrendo pela via estrita de uma diferença entendida como irredutível - sendo a vulnerabilidade dos corpos indígenas um aporte suficientemente complexo e capaz de conectar tal ordem de valores a uma hierarquia funcional bastante específica, cujo histórico remete aos valores mais caros do sanitarismo brasileiro. Tal estereótipo da alteridade indígena - ao ser percebida e vivida como alteridade biológica - atuava como síntese de todas as outras formas de diferença percebidas, atualizando o discurso da premência epistemológica do universal (como produtor de verdades) sobre o particular (como um vetor de especificidades ornamentais).

\section{Notas}

1 Esse dado está disponível em: <http://portal.saude.gov.br/portal/saude/Gestor/area.cfm?id_ area $=1744>$. Acesso em: 18 mar. 2013.

2 Ao longo do texto, usarei a forma feminina para designar o grupo da enfermagem, tendo em vista que as mulheres constituíram, no meu caso, a quase totalidade da equipe. Entretanto, esse não necessariamente é o caso de todos os Distritos Sanitários.

3 A pesquisa foi aprovada pelo Comitê de Ética em Pesquisa com Seres Humanos do Instituto de Ciências Humanas da Universidade de Brasília, de acordo com a resolução 196/96 do Ministério da Saúde, em 27/3/2009. Para uma análise crítica da resolução 196/96 no que tange à diferença entre pesquisar com seres humanos e pesquisar em seres humanos, ver Cardoso de Oliveira (2005). Além disso, a pesquisadora recebeu autorização da Fundação Nacional do Índio (Funai) para realizar entrada e permanência na terra indígena Munduruku durante os meses 
do trabalho de campo, entre 2008 e 2009. Finalmente, a pesquisadora também realizou uma reunião em aldeia apresentando seu trabalho e informando sobre a natureza da pesquisa às lideranças indígenas e aos profissionais da saúde, conforme os princípios do Código de Ética da Associação Brasileira de Antropologia (<www.abant.org.br/?code=3.1>), da qual a autora é sócia efetiva.

4 O nome de batismo e de casamento de Ana Néri difere da grafia com a qual seu nome ficou conhecido a partir do século XX, após sua morte, já na condição de pioneira da enfermagem brasileira. No resgate de seu nome durante a Reforma Sanitária, os documentos e textos da época começam a utilizar o nome Anna Nery, em vez de Ana Néri, sendo a nova grafia utilizada para dar nome à famosa Escola de Enfermagem do Rio de Janeiro (Cardoso G Miranda, 1999).

5 O Diário da Bahia foi um importante jornal local que circulou entre 1856 e os primeiros anos do século XX, comprometido com a causa abolicionista. Políticos ligados ao Partido Republicano Federalista, além de liberais como Rui Barbosa e Manuel Vitorino, publicavam no Diário (Silva, 1979).

6 Victor Meirelles é também autor das famosas obras A Primeira Missa no Brasil, Combate Naval de Riachuelo, Passagem de Humaitá, Batalha dos Guararapes e Juramento da Princesa Isabel.

7 Ver, além de Cardoso e Miranda (1999), Batista (2005), Baptista e Barreira (2009) e Almeida Filho (2004).

8 "As organizações sanitárias modernas não podem mais dispensar o serviço de enfermeiras visitadoras, que constituem um dos factores de maior valia na prática dos methodos prophylacticos. (...) Encarada em seu aspecto social, e interpretada na grandeza moral de seus objectivos, a função da enfermeira virá constituir para a mulher brasileira um vasto campo de actividade produtiva, na qual se exercitam todas as excellencias de su'alma piedosa e altruística, na qual se effectivam seus altos ideaes de emancipação pelo trabalho nobilitante" (Chagas apud Rizzotto, 2008: 51-52).

9 A referência mais ampla desse debate se encontra na tese de doutorado de Souza Lima, publicada na forma de livro em 1995, sobre poder tutelar e ação indigenista no Brasil (Souza Lima, 1995). O diálogo com este trabalho se dá no intuito de refletir sobre um poder tutelar cuja principal característica é se capilarizar em ações de benevolência, dispersas nas várias situações de interação de povos indígenas e agentes governamentais. São importantes, assim, pesquisas focadas em mapear tal diversidade de contextos para fins de uma análise mais consistente sobre a governamentalidade indigenista e suas correlações com as políticas setoriais para a saúde indígena.

10 Esses relatos também podem ser lidos em Murphy (1958).

11 Os nomes de todas as pessoas envolvidas na pesquisa de campo foram ocultados ou são fictícios. Essa escolha se refere a uma questão metodológica na antropologia, cuja preocupação central é resguardar os envolvidos de qualquer exposição individual negativa que possa vir a ser relacionada à pesquisa. Entendo que os indivíduos só ganham sentido em análises mais abrangentes e que transcendem suas próprias experiências individuais, por isso, embora sejam interlocutores fundamentais para a construção do conhecimento antropológico via etnografia, isso não significa que a identidade revelada seja de interesse da pesquisa. Ao contrário, é nas 
representações coletivas, manifestadas por meio dos indivíduos, que a antropologia encontra sua vocação intelectual.

12 Foucault (2004), ao pensar na construção do olhar clínico, ressalta que o treinamento do olhar pode ser entendido em relação a seu conceito de corpo e corpo disciplinado e, portanto, como uma prática simultaneamente consciente/inconsciente.

13 Aqui, apenas o primeiro nome em português foi ocultado. O nome do clã, porém, foi mantido em virtude de não ocasionar qualquer identificação individual e, também, por permitir construir o sentido da confusão descrita pelos atores.

14 O trabalho de campo realizado entre um grupo de estudantes de medicina nos primeiros anos do curso em Harvard permitiu a Byron Good e Mary-Jo Good perceber a forma como o corpo fora desconstruído e reconstruído pelas aulas de anatomia, do corpo que se movimenta ao corpo estático dos cadáveres.

15 Faz-se clara referência aqui à construção do argumento da ação fraternal nas ações indigenistas, como analisa Souza Lima (1987).

\section{Referências}

ABRAMS, P. Notes on the difficulty of studying the State. Journal of Historical Sociology, 1(1): 58-89, 1988.

AlMEIDA FILHO, A. J. A Escola Anna Nery (EAN) no "Front" do Campo da Educação em Enfermagem e o (Re)Alinhamento de Posições de Poder (1931-1949), 2004. Tese de Doutorado, Rio de Janeiro: Escola de Enfermagem Anna Nery, Universidade Federal do Rio de Janeiro.

AUSTIN, J. L. Quando Dizer é Fazer: palavras e ações. Porto Alegre: Artes Médicas, 1990.

BAPTISTA, S. G BARREIRA, I. A. Anna Nava, baluarte da escola Anna Nery (anos 1940/1970). Esc. Anna Nery Revista de Enfermagem, 13(3): 543-551, 2009.

BARROSO-HOFFMAN, M. Fronteiras Étnicas, Fronteiras de Estado e Imaginação da Nação: um estudo sobre a cooperação internacional norueguesa junto aos povos indígenas, 2008. Tese de Doutorado, Rio de Janeiro: Museu Nacional, Universidade Federal do Rio de Janeiro.

BATISTA, D. O. O Mito Anna Nery e a Enfermagem Brasileira, 2005. Dissertação de Mestrado, Rio de Janeiro: Escola de Enfermagem Anna Nery, Universidade Federal do Rio de Janeiro.

BATISTA E SILVA, M. B. Reforma, responsabilidades e redes: sobre o cuidado em saúde mental. Ciência G Saúde Coletiva, 14(1): 149-158, 2009.

BOURDIEU, P. O Senso Prático. Petrópolis: Vozes, 2009 [1980].

BRASIL. Ministério da Saúde. Fundação Nacional de Saúde. Política Nacional de Atenção à Saúde dos Povos Indígenas. 2. ed. Brasília: Fundação Nacional de Saúde, 2002. 
BRASIL. Ministério da Saúde. Secretaria de Vigilância em Saúde/Secretaria de Atenção à Saúde. Política Nacional de Promoção da Saúde. Brasília: Ministério da Saúde, 2006. (Série B, Textos Básicos de Saúde).

CARDOSO DE OLIVEIRA, L. R. Pesquisa em versus pesquisas com seres humanos. In: VÍCTORA, C. et al. Antropologia e Ética: o debate atual no Brasil. Brasília, Niterói: ABA, EdUFF, 2005.

CARDOSO, M. M. V. N. G MIRANDA, C. L. Anna Justina Ferreira Nery: um marco na história da enfermagem brasileira. Revista Brasileira de Enfermagem, 52(3): 339-348, 1999.

CHAVES, M. B. G.; CARDOSO, A. M. G ALMEIDA, C. Implementação da política de saúde indígena no polo-base Angra dos Reis, Rio de Janeiro, Brasil: entraves e perspectivas. Cadernos de Saúde Pública, 22(2): 295-305, 2006.

CORBELLINI, V. L. Fragmentos da história de enfermagem: um saber que se cria na teia do processo da submissão teórica. Revista Brasileira de Enfermagem, 60(2): 172-177, 2007.

CORREAA, J. G. S. Tutela G Desenvolvimento/Tutelando o Desenvolvimento: questões quanto à administração do trabalho indígena pela Fundação Nacional do Índio, 2008. Tese de Doutorado, Rio de Janeiro: Museu Nacional, Universidade Federal do Rio de Janeiro.

COSTA, R. et al. O legado de Florence Nightingale: uma viagem no tempo. Texto $G$ Contexto Enfermagem, 18(4): 661-669, 2009.

DIAS DA SILVA, C. Cotidiano, Saúde e Política: uma etnografia dos profissionais da saúde indígena, 2010. Tese de Doutorado, Brasília: Departamento de Antropologia, Universidade de Brasília.

DIAS DUARTE, L. F. Indivíduo e pessoa na experiência da saúde e da doença. Ciência $G$ Saúde Coletiva, 8(1): 173-183, 2003.

DIAS-SCOPEL, R. P. O Agente Indígena de Saúde Xokleng: o mediador entre a comunidade indígena e os serviços de atenção diferenciada à saúde - uma abordagem da antropologia da saúde, 2005. Dissertação de Mestrado, Florianópolis: Departamento de Antropologia, Universidade Federal de Santa Catarina.

ELIAS, N. O Processo Civilizador I. Rio de Janeiro: Jorge Zahar Editor, 1994 [1939].

ERTHAL, R. M. C. A formação do agente indígena de saúde Tikuna no Alto Solimões: uma avaliação crítica. In: COIMBRA, C. E. A.; SANTOS, R. V. G ESCOBAR, A. L. (Orgs.). Epidemiologia e Saúde dos Povos Indígenas no Brasil. Rio de Janeiro: Editora Fiocruz, Abrasco, 2003.

FASSIN, D. O sentido da saúde: antropologia das políticas da vida. In: SAILLANT, F. G GENEST, S. (Orgs.). Antropologia Médica: ancoragens locais, desafios globais. Rio de Janeiro: Editora Fiocruz, 2012.

FOUCAULT, M. O Nascimento da Clínica. Rio de Janeiro: Forense Universitária, 2004 [1980].

GARNELO, L. Poder, Hierarquia e Reciprocidade: saúde e harmonia entre os Baniwa do Alto Rio Negro. Rio de Janeiro: Editora Fiocruz, 2003. 
GARNELO, L. Política de Saúde dos Povos Indígenas no Brasil: análise situacional do período 1990 a 2004. Porto Velho, Rio de Janeiro: UFRO, Universidade do Amazonas, Centro de Pesquisas Leônidas G Maria Deane, Fundação Oswaldo Cruz, 2004.

GARNELO, L. G SAMPAIO, S. Bases socioculturais do controle social em saúde indígena: problemas e questões na região Norte do Brasil. Cadernos de Saúde Pública, 19(1): 311 $317,2003$.

GOOD, B. G GOOD, M.-J. Learning medicine: the constructing of medical knowledge at Harvard Medical School. In: LINDENBAUM, S. G LOCK, M. (Eds.). Knowledge, Power and Practice. Berkeley, Los Angeles, New York: University of California Press, 1993.

HERZFELD, M. The Social Production of Indifference: exploring the symbolic roots of Western bureaucracy. Chicago, London: The University of Chicago Press, 1992.

HOCHMAN, G. A Era do Saneamento. São Paulo: Hucitec, Anpocs, 2006.

KLEINMAN, A. Patients and Healers in the Context of Culture: an exploration of the borderland between Anthropology, Medicine and Psychiatry. Berkeley, Los Angeles, London: University of California Press, 1980.

KLEINMAN, A. The Illness Narratives. United States of America: Basic Books (Perseus Books Group), 1988.

KRUSE, M. H. L. Enfermagem moderna: a ordem do cuidado. Revista Brasileira de Enfermagem, 59(esp): 403-410, 2006.

LANGDON, E. J. G GARNELO, L. (Orgs.). Saúde dos Povos Indígenas: reflexões sobre antropologia participativa. Rio de Janeiro: Contra Capa, ABA, 2004.

LANGDON, E. J. et al. A participação dos agentes indígenas de saúde nos serviços de atenção à saúde: a experiência em Santa Catarina, Brasil. Cadernos de Saúde Pública, 22(12): 2.637-2.646, 2006.

MAGALHÃES, E. D. O Estado e a Saúde Indígena: a experiência do Distrito Sanitário Yanomami, 2006. Dissertação de Mestrado, Brasília: Departamento de Serviço Social, Universidade de Brasília.

MARQUES, I. S. F. A Política de Atenção à Saúde Indígena: a implantação do Distrito Sanitário Especial Indígena de Cuiabá-MT, 2003. Dissertação de Mestrado, Rio de Janeiro: Escola Nacional de Saúde Pública Sergio Arouca, Fundação Oswaldo Cruz, 2003.

MAUSS, M. As técnicas do corpo [1950]. In: MAUSS, M. Sociologia e Antropologia. São Paulo: Cosac G Naify, 2003.

MURPHY, R. F. Munduruku Religion. Berkeley, Los Angeles: University of California Press, 1958.

NOVO, M. P. Os Agentes Indígenas de Saúde do Alto Xingu. Brasília: ABA, Paralelo 15, 2010.

RIZZOTTO, M. L. F. História da Enfermagem e sua Relação com a Saúde Pública. Goiânia: AB Editora, 2008. 
SILVA, K. M. C. O Diário da Bahia e o Século XIX. Rio de Janeiro: Tempo Brasileiro, 1979.

SIMMEL, G. Conflict and the Web of Group-Affiliations. New York, London, Toronto, Sidney, Singapore: The Free Press, 1955.

SOUZA LIMA, A. C. Sobre indigenismo, autoritarismo e nacionalidade: considerações sobre a constituição do discurso e da prática da proteção fraternal no Brasil. In: OLIVEIRA FILHO, J. P. (Org.). Sociedades Indígenas e Indigenismo no Brasil. Rio de Janeiro, São Paulo: Ed. UFRJ, Marco Zero, 1987.

SOUZA LIMA, A. C. Um Grande Cerco de Paz: poder tutelar, indianidade e formação do Estado no Brasil. Petrópolis: Vozes, 1995.

SOUZA LIMA, A. C. Tradições de conhecimento para gestão colonial da desigualdade: reflexões a partir da administração indigenista no Brasil. In: BASTOS, C.; ALMEIDA, M. V. G FELDMAN-BIANCO, B. (Coords.). Trânsitos Coloniais: diálogos críticos luso-brasileiros. Lisboa: Imprensa de Ciências Sociais, 2002.

SOUZA LIMA, A. C. G MACEDO E CASTRO, J. P. Política(s) pública(s). In: PINHO, O. G SANSONE, L. (Orgs.). Raça: novas perspectivas antropológicas. Salvador: Associação Brasileira de Antropologia, Edufba, 2008.

TEIXEIRA, C. C. O Museu da Funasa e a Saúde Indígena. Brasília: Departamento de Antropologia, Universidade de Brasília, 2007. (Série Antropologia, 409).

TEIXEIRA, C. C. Interrompendo rotas, higienizando pessoas: técnicas sanitárias e seres humanos na ação de guardas e visitadoras sanitárias. Ciência G Saúde Coletiva, 13(3): 965-974, 2008.

TEIXEIRA, C. C. A produção política da repulsa e os manejos da diversidade na saúde indígena. Revista de Antropologia (USP), 55(2): 1-37, 2012. 


\section{O Papel e a Formação dos Agentes Indígenas de Saúde na Atenção Diferenciada à Saúde dos Povos Indígenas Brasileiros ${ }^{1}$}

Esther Jean Langdon

Eliana Elisabeth Diehl Raquel Paiva Dias-Scopel

A noção de atenção diferenciada para os povos indígenas do Brasil foi construída com base nos princípios e modelos propostos em diferentes documentos, como a Declaração de Alma-Ata (WHO, 1978), a Constituição brasileira (Brasil, 1988) e a Convenção 169 da Organização Internacional do Trabalho (OIT, 2005). Após quase duas décadas de debates e conferências nacionais de saúde, inclusive indígena, o Subsistema de Atenção à Saúde Indígena foi finalmente estabelecido em 1999, na forma de 34 Distritos Sanitários Especiais Indígenas (DSEIs), 2 objetivando fornecer atenção diferenciada para os povos indígenas. Uma estratégia desenvolvida, entre várias outras, para alcançar os objetivos da atenção diferenciada foi a institucionalização do agente indígena de saúde (AIS) como parte das equipes que prestam serviços de atenção primária nas aldeias. A institucionalização do AIS visa a atender a várias demandas, entre elas a criação de cargos assalariados para membros da comunidade, a ausência periódica de profissionais da saúde na aldeia e a mediação nas relações interétnicas. O papel do AIS é citado nos documentos da Política Nacional de Atenção à Saúde dos Povos Indígenas (PNASPI) como central para a realização do princípio da atenção diferenciada, ou seja, é destacado como ponto estratégico para a oferta de serviços de saúde sensíveis ao pluralismo e à diversidade cultural e que incorporam o direito da comunidade de participar, individual ou coletivamente, no seu planejamento, execução e avaliação. De acordo com a PNASPI, o AIS deve ser membro da comunidade onde irá atuar e eleito por ela para assumir a função.

Este capítulo pretende avaliar, após 15 anos de existência do subsistema, a implantação, formação e participação dos AISs nas equipes multidisciplinares de atenção básica à saúde indígena (EMSIs) e sua contribuição para os serviços de atenção diferenciada à saúde. A avaliação é baseada na revisão de pesquisas sobre a implantação de serviços de atenção à saúde indígena contendo informações sobre o AIS. São privilegiadas as pesquisas de natureza antropológica, suplementando os seus resultados e conclusões com as experiências das autoras em pesquisas sobre o papel do AIS em Santa Catarina (Langdon et al., 2006; Dias-Scopel, 2005; 
Dias-Scopel, Langdon G Scopel, 2007). ${ }^{3}$ Consultaram-se ainda a biblioteca Scielo, o banco de teses da Coordenação de Aperfeiçoamento de Pessoal de Nível Superior (Capes) e, para documentos oficiais, sítios eletrônicos de organismos nacionais e internacionais. Participações em bancas examinadoras e em eventos sobre a temática também serviram de fontes de informações (Diehl, Langdon G DiasScopel, 2012).

\section{Atenção Diferenciada e o Agente Indígena de Saúde}

Desde a $1^{\text {a }}$ Conferência Nacional de Proteção à Saúde do Índio, em 1986, o Ministério da Saúde vem-se esforçando para estruturar um subsistema diferenciado de saúde indígena, integrado ao Sistema Único de Saúde (SUS) e guiado pelos princípios de acesso universal, equidade, controle social, participação comunitária e, particularmente no caso dos indígenas, respeito e articulação com as especificidades étnicas dos grupos atendidos. Estes princípios são a base do Subsistema de Atenção à Saúde Indígena e estão expressados no documento PNASPI que define o modelo de atenção diferenciada. Nesse documento, respeito e articulação são formulados como componentes norteadores das ações nos serviços de saúde (Brasil, 2002a: 18):

O princípio que permeia todas as diretrizes da Política Nacional de Atenção à Saúde dos Povos Indígenas é o respeito às concepções, valores e práticas relativos ao processo saúde-doença próprios a cada sociedade indígena e a seus diversos especialistas. A articulação com esses saberes e práticas deve ser estimulada para a obtenção da melhoria do estado de saúde dos povos indígenas.

Nesse mesmo documento, o AIS é definido como o elo entre os membros da comunidade onde atua e os da equipe multidisciplinar, tendo a atribuição de articular os saberes tradicionais e biomédicos por meio de sua atuação nos serviços de atenção primária. As atividades de formação e capacitação são citadas como meio de consolidar esse papel:

Nas aldeias, a atenção básica será realizada por intermédio dos Agentes Indígenas de Saúde, nos postos de saúde, e pelas equipes multidisciplinares periodicamente, conforme planejamento das suas ações.

A formação e a capacitação de indígenas como agentes de saúde é uma estratégia que visa favorecer a apropriação, pelos povos indígenas, de conhecimentos e recursos técnicos da medicina ocidental, não de modo a substituir, mas de somar ao acervo de terapias e outras práticas culturais próprias, tradicionais ou não. (Brasil, 2002a: 14, 16, grifos das autoras) 
A capacitação e a supervisão dos profissionais de saúde, inclusive do AIS que está a cargo do gestor do subsistema ${ }^{4}$ - são vistas como fundamentais para o êxito de suas atuações (Brasil, 2002a: 16):

A capacitação dos recursos humanos para a saúde indígena deverá ser priorizada como instrumento fundamental de adequação das ações dos profissionais e serviços de saúde (...). Deverão ser promovidos cursos de atualização/aperfeiçoamento/ especialização para gestores, profissionais de saúde e assessores técnicos (indígenas e não indígenas) das várias instituições que atuam no sistema.

\section{Antecedentes}

A concepção do papel do AIS teve como referência a proposta para o agente comunitário de saúde (ACS), seja este índio ou não, lançada há mais de três décadas pela Declaração da Alma-Ata, já citada (WHO, 1978). A declaração recomenda que a medicina tradicional seja promovida, desenvolvida e integrada com a biomedicina onde quer que seja possível e visa ao acesso universal e integral aos cuidados primários de saúde, enfatizando promoção, prevenção, cura e reabilitação a um custo acessível, e à garantia de respeito, reconhecimento e colaboração entre os representantes das práticas tradicionais e os da biomedicina. Para atingir suas metas de atenção integral a custo acessível, estabelece estratégias preventivas descentralizadas e com base na comunidade, citando os recursos de ACS, grupos comunitários de saúde, curandeiros tradicionais e líderes comunitários. O ACS é, então, definido como um membro da comunidade específica, cuja tarefa é melhorar a saúde, aconselhando seus pares sobre as estratégias de prevenção e cuidados de saúde e também prestando serviços de primeiros socorros (Helman, 2003).

No Brasil, os ACSs - inicialmente inscritos no Programa Nacional de Agentes Comunitários, criado em 1991 pelo Ministério da Saúde e que passou a se chamar, em 1992, Programa de Agentes Comunitários de Saúde (Pacs) - foram também incorporados às equipes do Programa de Saúde da Família (PSF) 5 a partir de 1994, sendo reconhecidos como profissionais da saúde somente em 2002, pela lei n. 10.507/2002 (Brasil, 2002b). ${ }^{6}$ Segundo essa lei, a profissão de ACS caracteriza-se pelo exercício de atividade de prevenção de doenças e promoção da saúde, mediante ações domiciliares ou comunitárias, individuais ou coletivas, desenvolvidas em conformidade com as diretrizes do SUS e sob supervisão do gestor local. Para Márcia Cardoso Morosini (2009), com essa lei e a criação da Secretaria de Gestão do Trabalho e da Educação na Saúde (SGTES) em 2003 pelo Ministério da Saúde, "as questões da precariedade da formação, bem como da precariedade dos vínculos dos ACS, passaram a se expressar na agenda do Ministério da Saúde de maneira central" (Morosini, 2009: 17). 
A $1^{\text {a }}$ Conferência Nacional de Proteção à Saúde do Índio visou a estabelecer os princípios e as necessidades da organização da saúde indígena. Contando com representação importante das organizações indígenas, o documento final da conferência introduziu os princípios que fundamentaram o conceito de atenção diferenciada, indicando a necessidade do estímulo à formação de pessoal em saúde nas próprias comunidades (agentes de saúde, auxiliares de enfermagem, enfermeiros etc.) e "que a remuneração de agentes de saúde indígenas deve obedecer aos critérios e definições das comunidades a que pertencem os mesmos" (Krenak et al., 1988: 3).

Na prática, desde a década de 1980 os AISs estavam sendo treinados e incluídos nos serviços de atenção primária prestada por algumas universidades e organizações não governamentais (ONGs). Cabe destacar: o Projeto Xingu, da Universidade Federal de São Paulo (Mendonça, 1996, 2005; Oliveira, 2002, 2005); a ONG Health Unlimited; o Conselho Indigenista Missionário (Cimi) e a União de Nações Indígenas (UNI-Acre) no rio Envira, no estado do Acre (Bittencourt $G$ Toledo, 2005); a Diocese de São Gabriel da Cachoeira; a ONG Saúde Sem Limites (SSL); o Projeto da Rede Autônoma de Saúde Indígena (Rasi) da Fundação Universidade do Amazonas; a Federação das Organizações Indígenas do Rio Negro (Foirn) e a Fundação Nacional de Saúde (Funasa), na região do rio Negro (Garnelo, 2001; Argentino, 2005); o Conselho Geral das Tribos Tikuna (CGTT), com a participação da Faculdade de Medicina da Universidade Federal do Rio de Janeiro (UFRJ) e o Núcleo de Estudos em Saúde dos Povos Indígenas (Nespi) da Fundação Oswaldo Cruz (Fiocruz) (Confalonieri G Verani, 1993; Erthal, 2003); e a Pastoral da Criança, ligada à Conferência Nacional dos Bispos do Brasil (CNBB), em Santa Catarina (Diehl, 2001). ${ }^{7}$

Na maioria dos casos, os AISs foram introduzidos para fins de tradução e ampliação da atenção primária às populações isoladas, de difícil acesso e sem domínio da língua portuguesa. Suas tarefas e responsabilidades, bem como a remuneração, variaram dependendo do contexto específico e do provedor de serviços básicos. No Xingu, por exemplo, os agentes começaram como tradutores, realizando atividades que visavam a ampliar a cobertura da assistência médica na ausência contínua da equipe nas aldeias (Mendonça, 2005). No rio Negro, os missionários começaram com o treinamento dos AISs, como voluntários, em primeiros socorros; com a epidemia do cólera em 1991-1993, o governo federal empregou esses agentes no combate à doença. Quando o programa terminou, vários desistiram de continuar atuando, enquanto outros permaneceram como voluntários. Alguns AISs Tikúna, capacitados pela Universidade Federal do Rio de Janeiro (UFRJ) e pela Escola Nacional de Saúde Pública Sergio Arouca (Ensp) da Fiocruz, também foram treinados para combater essa doença (Confalonieri $G$ Verani, 1993). Na segunda parte da década de 1990, foram oferecidos cursos de capacitação aos AISs pela Rasi em convênio com a organização indígena Foirn e 
a Funasa (Souza, Cavalcante G Brandão, 2002), mediante uma abordagem educacional mais dialógica, reconhecendo que os índios ativamente reformulam e ressignificam os conhecimentos apresentados nos cursos (Garnelo, 2001). Nesse caso, muitos que realizaram os cursos foram subsequentemente contratados pelo Pacs. Outro exemplo, já no início de 2000, foi o treinamento e a contratação de índios Yanomami como microscopistas no combate à malária, cujas atividades foram avaliadas positivamente pela equipe médica (Bissera, 2006). No Sul, Região na qual os índios se encontram em contato contínuo com a sociedade envolvente e sofrendo de doenças carenciais (Langdon G Rojas, 1991), a Pastoral da Criança organizou cursos para capacitação em primeiros socorros, fitoterapia e preparação da multimistura, ${ }^{8}$ porém poucos índios foram absorvidos pelo Pacs, como no caso de outras regiões (Oliveira, 1996). Atualmente, alguns índios são contratados como agentes comunitários pela Estratégia Saúde da Família, como tem sido o caso na terra indígena (TI) Xapecó.

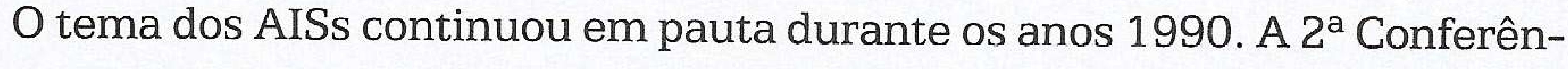
cia Nacional de Saúde Indígena, realizada em 1993, teve como objetivo a definição das diretrizes da Política Nacional de Saúde Indígena e do estabelecimento de um subsistema. Essa conferência recomendou o reconhecimento pelo Ministério da Saúde da categoria profissional de AIS, regularizando-a e inserindo-a no subsistema diferenciado de atenção à saúde do índio. Apesar da demanda para o reconhecimento e a incorporação dos agentes indígenas na atenção à saúde, apoiados pelas organizações indígenas e profissionais da saúde, a Coordenação de Saúde do Índio (Cosai) da Funasa, encarregada pela saúde indígena em parte dos anos 1990, não teve as condições financeiras nem organizacionais para implantar um programa amplo e eficaz de formação e remuneração dos AISs. ${ }^{9}$

Em 1996, a Cosai divulgou o documento Formação de Agentes Indígenas de Saúde: proposta de diretrizes, resultado de quatro fóruns macrorregionais (Brasil, 1996a). Nesse documento, foi atribuído ao AIS uma função-chave na mediação dos serviços de saúde, visualizado como ator central para a promoção dos princípios de respeitar as tradições indígenas e se articular com elas. $O$ documento recomendou ainda que a formação do AIS incluísse informações sobre antropologia, política de saúde e organização dos serviços, além de noções básicas de biomedicina, técnicas básicas de enfermagem e outros assuntos relacionados à saúde comunitária. Sua formação também deveria incluir uma discussão sobre medicina tradicional e a visão nativa do processo saúde-doença, da cura e da morte e sua relação com a cosmologia, para reconhecer a especificidade cultural do grupo.

Três projetos (Rio Envira-Acre, Xingu e Alto Rio Negro) que visavam a formar e introduzir o AIS e que antecederam a criação dos DSEIs têm sido objeto de várias reflexões e avaliações pelos atores envolvidos (Bittencourt et al., 2005; Mendonça, 1996, 2005; Garnelo, 2001; Souza, Cavalcante G Brandão, 2002), sendo 
possível observar certas características dessas experiências que as distinguem das que vinham sendo implementadas pela Funasa após 1999. Sem apoio de recursos financeiros da Cosai, as iniciativas desses projetos surgiram em razão das necessidades locais e com a colaboração de vários atores nos níveis local e regional. Entre eles, podemos citar os profissionais responsáveis pelos serviços, organizações indígenas, ONGs, universidades e escolas técnicas. Ainda mais, todos os cursos oferecidos por eles foram caracterizados pelo acompanhamento antropológico, visando a adequar os projetos às especificidades culturais. As atividades realizadas nas estratégias pedagógicas ou nas atribuições do AIS foram desenvolvidas em razão das situações específicas e da motivação para resolver os problemas locais de doenças, distribuindo os serviços de saúde de maneira sensível à realidade cultural em que a equipe se encontrava. Assim, os cursos de formação dos AISs foram desenhados segundo as especificidades locais, com grupos étnicos particulares, reconhecendo a necessidade de se adaptarem as estratégias pedagógicas a essas realidades.

\section{A Funasa e os Agentes Indígenas de Saúde}

Em 1999, a Cosai divulgou outro documento objetivando normatizar a implantação do Programa de Agentes Indígenas de Saúde como parte do processo de construção dos DSEIs (Brasil, 1999). A partir da criação dos distritos sanitários em 1999, o Departamento de Saúde Indígena (Desai) da Funasa, que substituiu a Cosai, recebeu um aumento significativo no orçamento para implantar os serviços de saúde indígena em todo o Brasil (Garnelo, 2003), o que permitiu um avanço na institucionalização do papel do AIS.

Segundo os dados do documento de 1999, existiam no país cerca de dois mil AISs no final da década de 1990, e mais de $70 \%$ deles trabalhavam sem acompanhamento ou supervisão. O documento enfatizava a necessidade da capacitação dos AISs, que deveria ocorrer preferencialmente em serviço e de forma continuada, sob a responsabilidade do instrutor-supervisor, lotado na equipe de saúde dos distritos, com a participação e a colaboração de outros profissionais do serviço de saúde. Entre alguns aspectos, o documento mencionava que o reconhecimento de sua profissão deveria ser garantido, citando a Lei de Diretrizes e Bases da Educação Nacional (LDB) (Brasil, 1996b).

Esforços para incorporar os AISs nos serviços primários aumentaram, por meio de sua contratação como parte das EMSIs para garantir acesso universal e diferenciado. Somado ao aumento do número de EMSIs, o número de agentes contratados mais que dobra entre 2000 e 2006. Dados indicam que houve uma diminuição em 2007 (Tabela 1), mas, na impossibilidade de conseguir informações sobre os anos mais recentes e ante a diversidade das fontes de dados, é difícil interpretar essa retração. 
Tabela 1 - Número de agentes indígenas de saúde (AISs) após a criação dos distritos sanitários especiais indígenas

\begin{tabular}{lc}
\hline Período & Número de AISs \\
\hline $2000^{*}$ & 2.284 \\
$2002^{*}$ & 2.732 \\
$2006^{* *}$ & 5.106 \\
$2007^{* * *}$ & 3.883 \\
\hline
\end{tabular}

Fontes: *Funasa, 2002; **Funasa, 2006; ***IDS/SSL/Cebrap, 2009.

A expressão do apoio da institucionalização do papel do AIS encontra-se no documento final da $3^{\text {a }}$ Conferência Nacional de Saúde Indígena, realizada em 2001, que contém várias propostas reafirmando e aprofundando as demandas sobre a formação, o reconhecimento e a inserção social dos AISs, entre elas (Brasil, 2001): o aumento do número de agentes por comunidade e EMSI, a necessidade de formação básica de todos, garantia do processo de capacitação contínua e diferenciada, acompanhamento técnico/pedagógico e administrativo no processo de formação e contratação pela Consolidação das Leis do Trabalho.

É necessário qualificar a regularidade e a composição das EMSIs nas aldeias menos isoladas, pois pesquisas indicam alta rotatividade dos profissionais da saúde desde o início da implantação dos 34 DSEIs (Garnelo, Macedo G Brandão, 2003), resultando em interrupções no atendimento. Ainda que em regiões relativamente acessíveis, em muitas ocasiões, os profissionais não apareciam nos dias marcados e havia uma flutuação do número e da composição das equipes ao longo do tempo (Langdon et al., 2006). Essa irregularidade dos serviços é atribuída aos muitos problemas de organização e contratação, entre eles os convênios realizados pela Funasa com as ONGs (Garnelo, Macedo G Brandão, 2003; Langdon et al., 2006), renovados anualmente e que resultam em rupturas de pagamentos e insegurança de emprego. Também contribuem para a rotatividade a organização política interna, inerente a cada grupo indígena, e a política externa que caracteriza as relações político-partidárias nos municípios que têm terras indígenas em seus territórios. A alta rotatividade dos profissionais que atuam na saúde indígena traz repercussões diversas para a qualidade da prestação dos serviços, com efeitos, inclusive, nas práticas de controle de informações e dados sobre saúde, refletindo na descontinuidade desses dados (Novo, 2010a) e na capacitação, uma vez que esta é, ainda, muito irregular (Erthal, 2003; Rocha, 2007). Ressalta-se também que a alta rotatividade dos profissionais não indígenas nas EMSIs tem impactos negativos na supervisão dos AISs e nas relações com eles. 
Apesar do aumento do número de AISs contratados, os dados das pesquisas revisadas sugerem que o papel do agente é heterogêneo e dinâmico (Mendonça, 2005; Dias-Scopel, Langdon G Scopel, 2007; Silva, 2007; Novo, 2010a) e que as problemáticas envolvidas na formação são muitas. A heterogeneidade geográfica e o grau de contato com a sociedade envolvente permanecem espelhando a heterogeneidade de papéis dos AISs. No caso dos grupos mais isolados, alguns seguem realizando cuidados primários e servindo de intérpretes. Os agentes que se encontram em comunidades que mantêm contato contínuo com a sociedade envolvente trabalham como assistentes dos profissionais das EMSIs, realizando tarefas limitadas e mal definidas, como é o caso de Santa Catarina. Entre os Munduruku (Pará), há diferenças de atividades entre os agentes dependendo se sua locação é no polo-base ou na aldeia, sendo que a atribuição de assistente dificulta a realização das atividades como mediador (Silva, 2010). Outro fator que contribui para a heterogeneidade de ações e papéis dos AISs é a variação do seu grau de escolarização, pois alguns não têm formação escolar, enquanto outros têm o ensino fundamental ou médio, completo ou incompleto. Outros vêm buscando profissões reconhecidas na saúde, como auxiliar ou técnico de enfermagem. No caso de Santa Catarina, por exemplo, o emprego como AIS tem estimulado vários índios a entrarem por sua própria iniciativa em cursos técnicos, de modo a garantir um emprego melhor e mais seguro.

A formulação da PNASPI em 2000 ressalta a necessidade de cursos de capacitação dos AISs serem uma prioridade. A partir de então, foram desenvolvidos modelos pela Funasa em nível nacional, orientando a formação às questões e técnicas sobre problemas comuns de saúde. Porém, os dados sobre quantos agentes têm sido capacitados ao longo dos anos são poucos e contraditórios. Na análise sobre a implantação do subsistema e as atividades da Funasa, Garnelo, Macedo e Brandão (2003) reconhecem a ênfase especial dada à formação dos AISs, mas simultaneamente observam que existem dificuldades na provisão dos cursos de capacitação, tanto para os agentes quanto para os demais profissionais.

Apesar da multiplicidade de contextos e atividades dos AISs nos DSEIs, as pesquisas mostram certas tendências gerais, dificuldades e avanços na institucionalização do agente indígena desde a implantação do subsistema, que podem ser resumidos em: alta rotatividade e suas implicações, ambiguidade do papel, relacionamento com os membros das equipes de saúde e formação e capacitação.

\section{Alta Rotatividade e Suas Implicações}

A $3^{a}$ Conferência Nacional de Saúde dos Povos Indígenas propôs: "A seleção dos agentes indígenas de saúde será feita pelas comunidades indígenas, observando critérios e diretrizes dos Conselhos Locais, Distritais e da Funasa" (Brasil, 2001: 11). 
A revisão das etnografias estudadas aponta que a especificidade dos fatores que subjazem à indicação dos indígenas ao cargo de AIS ou às mudanças nos demais cargos da EMSI não pode ser entendida sem uma análise das particularidades socioculturais de cada povo e do contexto político-partidário regional.

No caso da indicação dos AISs, sobressaem as dinâmicas da organização social e dos processos políticos inerentes a cada grupo indígena como fatores que constituem parte dos critérios de legitimidade. Entre os Baniwa, por exemplo, as indicações para os cargos de agentes seguem as dinâmicas sociocosmológicas e políticas das hierarquias internas organizadas segundo os grupos de parentesco Baniwa e, também, os critérios inerentes à legitimação de cargos de lideranças e prestígio, como disciplina pessoal, respeito aos valores morais, domínio da língua portuguesa e desenvoltura nas interlocuções com os brancos, entre outros fatores (Garnelo, 2003; Rocha, 2007). Regina Erthal (2003) detalha como a escolha do AIS é feita entre as afiliações políticas das lideranças Tikúna e o surgimento de conflitos como consequência da criação do cargo assalariado, e Cinthia Rocha (2005) indica que os não indígenas da EMSI reclamaram que os agentes, em uma comunidade Kaingáng de Santa Catarina, foram selecionados segundo as alianças de parentesco, e não segundo a motivação ou capacidade para o serviço em saúde.

As organizações sociais e políticas dos indígenas que implicam a escolha dos AISs e sua eventual demissão ou troca não devem ser vistas de modo negativo, pois são esses mesmos arranjos que constituem seus parâmetros de controle sobre as ações dos agentes. O caso do Xingu é particularmente ilustrativo da importância da organização social e dos processos políticos no êxito do desempenho dos serviços. No início do desenvolvimento de formação dos AISs, a equipe médica da Escola Paulista de Medicina - atual Universidade Federal de São Paulo (Unifesp) escolheu os agentes segundo seus critérios, porém essa estratégia causava falta de aceitação da comunidade e insegurança nos agentes. Subsequentemente, os responsáveis da Unifesp negociaram com as comunidades a seleção dos AISs, e, então, as escolhas seguiram as linhas de poder político e as linhagens de parentesco das aldeias, resultando em mais segurança dos agentes e melhor relacionamento com as comunidades (Mendonça, 2005; Rech, 2008).

Após a implantação do DSEI Rio Negro-Amazonas, critérios técnicos passaram a compor a exigência de pré-requisitos para a indicação dos AISs, como a escolaridade formal, por exemplo (Rocha, 2007). Entre os Xokleng, de modo semelhante, a equipe do polo-base, a ONG conveniada da Funasa e o DSEI Interior Sul/ Santa Catarina procuraram desenvolver mecanismos técnicos de controle da indicação aos cargos de AISs. Em 2003, foi realizado um processo seletivo por meio da aplicação de uma prova, na tentativa de contornar os critérios e processos sociopolíticos Xokleng de legitimação dos cargos de liderança e de AIS condizentes com as relações de poder e de parentesco (Langdon et al., 2006; 
Dias-Scopel, Langdon $G$ Scopel, 2007). Em ambos os contextos, as consequências dessas exigências pautadas em critérios técnicos foram a insegurança dos indígenas que atuavam como AISs e a saída de alguns que não se adequavam aos requisitos.

Dois fatores que influem na rotatividade dos AISs são os mesmos que impactam a alta rotatividade dos demais profissionais da EMSI, ou seja, o tipo de vínculo empregatício definido pelas contratações anuais e as divergências salariais. Entre os Xokleng, observou-se que a alta rotatividade dos AISs foi decorrente dos intervalos entre as renovações dos convênios da Funasa com a ONG, que provocavam períodos de trabalho sem salário, desestimulando a permanência no cargo. A divergência entre os salários dos profissionais também contribui para o desestímulo à permanência no emprego, tornando-se particularmente crítica no caso de aldeias isoladas, onde o AIS é o único membro permanente da EMSI, realizando atividades designadas sob a responsabilidade dos outros profissionais que recebem mais que ele. Uma solução para a insatisfação dessas condições de trabalho tem sido a busca para formação técnica, a exemplo de Santa Catarina, como se verá adiante.

Os arranjos político-partidários regionais são fatores que também causam impacto na rotatividade da EMSI. No contexto de Santa Catarina, por exemplo, a influência das disposições político-partidárias repercute na composição da EMSI contratada pela ESF vinculada ao município. Na TI Xapecó, na porção territorial de um dos municípios, ${ }^{10}$ entre maio e julho de 2004 havia dois grupos de AISs que se distinguiam pela contratação via ONG ou via município: nove agentes eram contratados pela ESF, e sete pela ONG indígena conveniada com a Funasa naquele momento. Durante a pesquisa, realizada em ano eleitoral, os AISs manifestaram temor quanto à perda de emprego caso fosse eleito o candidato da chapa de oposição, o que de fato veio a ocorrer. Em janeiro de 2007, observou-se que nas aldeias localizadas no território desse município havia 12 AISs, todos contratados pela ESF, sendo que dos 16 que trabalhavam em 2004, menos da metade permanecia no cargo. Em fevereiro de 2008, nas aldeias do mesmo município, havia nove AISs pela ESF, e somente dois deles trabalhavam desde 2004.

\section{Ambiguidade do Papel}

As ações de saúde a serem realizadas pelos AISs podem ser resumidas em (Funasa, 2007): acompanhamento de crescimento e desenvolvimento, gestantes, pacientes crônicos, vacinação e tratamentos de longa duração; atendimento aos casos de doenças mais frequentes (infecção respiratória, diarreia, malária); primeiros socorros; promoção à saúde e prevenção de doenças de maior prevalência.

Como indicado, na prática as ações realizadas pelos AISs são diversas, e o contexto específico demarca sobremaneira tais ações. Podem-se identificar dois 
aspectos que influenciam a natureza das responsabilidades dadas ao agente: o grau de inserção do grupo na sociedade envolvente e a compreensão que a EMSI tem dos princípios da atenção diferenciada. Reconhece-se que o êxito em oferecer serviços que respeitam as práticas tradicionais e se articulam com elas depende em grande medida do compromisso da ONG conveniada ou do município prestador e de seus esforços para capacitar todos os membros da EMSI, inclusive os AISs, para a atenção diferenciada.

No contexto de indígenas vivendo em região isolada, com menos contato com a sociedade envolvente (e, portanto, onde a maior parte da população não fala o português), encontra-se frequentemente uma delimitação mais clara do papel do AIS, como tem sido o caso do Xingu (Mendonça, 2005; Rech, 2008), do Rio Negro (Souza, Cavalcante G Brandão, 2002) e da área Yanomami (Bissera, 2006). Nessas regiões, as equipes de saúde não estão continuamente em todas as aldeias, e o AIS tem uma função importante como intérprete e executor de serviços ampliados, realizando tarefas específicas como atendimento às doenças mais frequentes e administração de primeiros socorros. Porém, nos contextos em que o grupo está em contato regular com os não indígenas e em maior dependência do mercado capitalista, as atribuições do AIS tendem a ser mal definidas, resultando em ambiguidades que tornam esse papel frustrante para todos os atores envolvidos.

No caso de Santa Catarina (Langdon et al., 2006), a análise de uma cartilha e a pesquisa demonstraram que as atividades delegadas aos AISs são amplas e pouco precisas, causando insegurança nos agentes. Segundo os olhares oficiais, elas se agrupam em quatro funções gerais: 1) visitas domiciliares; 2) educação e orientação sobre cuidados de saúde e informações sobre o sistema de saúde e seu funcionamento, incluindo os programas especiais; 3) preenchimento de vários formulários, tais como a ficha de visitas com assinatura de membro da família, os relatórios mensais de suas atividades e outros solicitados pela equipe; e 4) participação nas atividades de controle social.

Acompanhando os agentes e em diálogo com eles, verificou-se que essas funções frequentemente foram focos de tensão e frustração (Langdon et al., 2006). A lógica das visitas domiciliares se confrontou com a lógica social e política das comunidades, causando mal-entendidos e o não cumprimento do objetivo formal da visita, ou seja: o AIS passava nas casas para conseguir a assinatura do chefe da família, sem realizar a entrevista completa exigida pelo serviço. Observou-se que essas comunidades são organizadas por meio de redes de parentesco e práticas sociais que, de fato, mantinham as pessoas a par dos acontecimentos, tornando difícil para o AIS entender a razão da visita como recurso de obtenção de informações sobre a saúde da família, já que ele era integrante dessa rede de comunicação. Segundo Cristina Silva (2010), as ricas informações sobre saúde que aparecem na interação comunicativa que faz parte das visitas familiares são ignoradas quando 
reduzidas à produção de relatórios pelos AISs. Além disso, como demonstrado em outras pesquisas (Garnelo, 2003; Wawzyniak, 2008), se por um lado as redes sociais indígenas locais implicam sociabilidade, parentesco e relações políticas, por outro o cumprimento das funções e tarefas, como a visita a todas as casas, exige que o AIS opere independentemente desses processos locais.

Os dados demonstram que o AIS é membro de uma equipe hierarquizada segundo conhecimentos e funções, em que os cuidados de atenção primária são delegados ao auxiliar ou técnico de enfermagem e não aos agentes. Na TI Xapecó, por exemplo, os AISs que haviam sido treinados pela Pastoral da Criança para algumas práticas de atenção básica reclamaram que essas tarefas foram proibidas, pois eram de responsabilidade do auxiliar de enfermagem. Da mesma forma, o acompanhamento do crescimento das crianças foi retirado de sua responsabilidade, tornando a função do AIS restrita à distribuição de medicamentos e de avisos relacionados a ações e serviços de saúde, como dia de vacinação, de exame ou de consulta especializada (Dias-Scopel, 2005; Langdon et al., 2006; Dias-Scopel, Langdon G Scopel, 2007; Marinho G Ott, 2007; Novo, 2010a, 2010b; Wawzyniak, 2008).

Entretanto, é importante reconhecer a centralidade que o AIS pode assumir ao acompanhar os tratamentos de doenças crônicas e infectocontagiosas de longa duração. Esse foi o caso observado em uma pesquisa realizada entre os anos de 2005 e 2007 em Autazes (AM) na população Mura. A participação dos agentes revelou-se fundamental para o tratamento de alguns casos de tuberculose e hanseníase, especialmente naqueles em que a família, entre outros fatores, não dispunha de recursos financeiros ou de tempo para deslocar-se até a cidade em busca do medicamento (Scopel, 2007).

De maneira geral, as pesquisas mostram que as atribuições dos AISs são marcadas por relação hierárquica entre os profissionais da EMSI e reduzidas à negociação e intermediação com a população indígena (Dias-Scopel, 2005; Langdon et al., 2006, Silva, 2010; Wawzyniak, 2008). Como será analisado adiante, os AISs frequentemente percebem que são alvos de preconceitos e que seu trabalho não recebe o reconhecimento dos membros das EMSIs nem dos profissionais nos serviços da rede de referência do SUS, em que eles muitas vezes servem de acompanhantes de pessoas doentes de suas comunidades. Certamente, um fator que contribui para tal situação, além da natureza hierárquica implícita nos serviços médicos, é a falta de cursos de capacitação dos AISs. Também se retornará a este assunto.

Se, por um lado, os AISs declaram que suas relações com a equipe não são boas, por outro, eles sentem que sua função é mal-entendida pela comunidade. Durante a pesquisa em 2004 (Langdon et al., 2006), os agentes Xokleng e Kaingáng relataram que ocupavam posições marcadas por demandas contraditórias, pois as famílias esperavam que cumprissem atividades dos médicos ("Elas acham que 
devemos ser médicos", segundo o depoimento de uma AIS na TI Xapecó) (Langdon et al., 2006: 2.641), entretanto a orientação da equipe era para não realizarem atividades básicas de atenção primária, tais como medir febre e pressão arterial, recomendar e fornecer medicamentos e aplicar injeções - essas seriam tarefas dos auxiliares e outros membros da equipe. Vianna e Ott (2007) também relatam um caso em que o agente enfrentava demandas da comunidade que não fazem parte das atribuições do cargo.

Os AISs, na perspectiva da população indígena, são incorporados como agentes que representam a prática biomédica, decorrente do fato que eles emergem no contexto da interação inter e intraétnica como atores que detêm um conhecimento específico e são capazes de garantir o acesso aos recursos materiais e simbólicos ofertados pelos serviços de saúde, tais como medicamentos, por exemplo (Erthal, 2003; Garnelo, 2003; Silva, 2007; Silva, 2010).

Além das atividades nos serviços de saúde propriamente ditos, os AISs vêm sendo selecionados como conselheiros de saúde nos níveis local e distrital. Por exemplo: 19\% dos agentes do DSEI Xingu foram conselheiros de saúde em 2007 (Rech, 2008). A emergência dos AISs como figuras políticas centrais em determinados espaços de atuação política de certa forma é reflexo do acesso privilegiado, ainda que não de maneira autônoma, aos saberes e práticas biomédicos (Silva, 2007; Novo, 2010a, 2010b). Silva relata que os AISs Atikum (PE) têm participação ativa como conselheiros locais de saúde, destacando pontos que dificultam a execução das ações os fatores restritos aos serviços de saúde, tais como "falta de medicamento, maior regulação dos transportes locados, entre outros serviços de responsabilidade do DSEI-PE" (Silva, 2007: 47). No outro extremo, no âmbito do DSEI Interior Sul e de seu Conselho Distrital, AISs foram conselheiros, porém em alguns casos observou-se uma situação ambígua, pois ao atuarem no Conselho como representantes dos usuários (e, portanto, vocalizadores das demandas comunitárias), suas intervenções podiam ser vigiadas (e cobradas) pelas instituições empregadoras (Langdon G Diehl, 2007).

\section{Relacionamento com os Membros das Equipes de Saúde}

Como visto, as relações com os membros da EMSI, frequentemente, não são positivas ou construídas em diálogo. Em parte, os profissionais não estão sempre livres dos preconceitos que marcam as relações interétnicas vigentes entre indígenas e não indígenas e, como já mencionado, outros fatores que impedem uma relação dialógica são a organização hierárquica que permeia a profissão médica e a alta rotatividade dos membros da EMSI. Em Santa Catarina (Langdon et al., 2006, 2.642), os AISs com mais tempo de serviço referiram-se a uma relação melhor no passado: 
"Hoje a equipe nem sabe quem é AIS". Houve avaliação por parte dos AISs sobre a falta de habilidade dos outros profissionais para atuar no contexto indígena: "não sabe lidar com o índio, não conhece a nossa realidade" (Langdon et al., 2006: 2.642). Os agentes distinguiam entre os profissionais da saúde aqueles que, segundo sua percepção, estão ao lado dos indígenas e os que demonstram preconceito. Por exemplo, os AISs da TI Xapecó lembravam-se de um enfermeiro que, aos seus olhos, demonstrou uma atitude de preconceito quando argumentou contra o uso do fogo de chão nas casas indígenas. Interpretando isso como uma acusação de que eles eram sujos, uma agente comentou: "O índio não é sujo; todos nós têm roupa limpa no varal" (Langdon et al., 2006: 2.642).

Esta última afirmação não trata de um caso isolado, mas de fato da ideologia higienista e campanhista implícita na formação da Funasa (Teixeira, 2008). Talvez a situação mais extrema tenha sido a de desnutrição entre os Guarani Kaiowá no Mato Grosso do Sul. Em uma reunião em 2004 sobre desnutrição nesse grupo, a primeira autora deste capítulo assistiu a uma palestra da nutricionista do polo-base da Funasa, que publicamente declarou que as mães indígenas contribuem para a alta taxa de desnutrição por não cuidarem de seus filhos adequadamente, citando como fatores causais a comida inconsistente, os horários errados de dar alimentação e a falta de preocupação por parte das mães. João Wawzyniak (2008) destaca que as equipes que visitam as comunidades ribeirinhas e indígenas no rio Tapajós expressam a moralidade da biomedicina, definindo sua tarefa como a de transformar os hábitos da comunidade, eliminando os tabus e superstições que resultam em problemas de higiene e nutrição.

A organização hierárquica das equipes repercute nos procedimentos burocráticos exigidos aos AISs, tornando a relação entre eles e a EMSI ainda mais formal e assimétrica. Em várias pesquisas cita-se o preenchimento de numerosos formulários como um fator que burocratiza o trabalho e tende a servir muito mais como um exercício de controle e fiscalização, substituindo o acompanhamento e a supervisão previstos (Erthal, 2003; Langdon et al., 2006; Marinho G Ott, 2007; Silva, 2010; Vianna G Ott, 2007; Wawzyniak, 2008). Nas interações observadas em Santa Catarina entre um profissional da EMSI e os agentes, o preenchimento das planilhas ocupou o tempo da reunião, sobrando pouco - ou nenhum - para que efetivamente se discutissem os problemas enfrentados pelos agentes no seu dia a dia. Os AISs manifestaram frustração com o número elevado de formulários a serem preenchidos sem entenderem o objetivo de tais documentos. As agentes da TI Ibirama-Laklãnõ reclamaram que os outros membros da EMSI não as escutavam e assim não conheciam os problemas: "Todos têm que preencher os relatórios cada mês, e os profissionais não leem". ${ }^{11}$ Cristina Silva (2010) informa que a produção de formulários, que não são lidos nem discutidos, serve para reforçar a lógica hierárquica da organização das EMSIs entre os Munduruku do Pará. 
Durante as reuniões entre os AISs e os coordenadores das EMSIs (que as autoras acompanharam), visando a concluir as planilhas mensais de atividades e controle epidemiológico, ficou evidente um clima de tensão entre os primeiros e a coordenação, que inquiria sobre a qualidade e a fidedignidade dos dados presentes nos documentos. Por exemplo, no posto de saúde de uma das aldeias da TI Xapecó, os AISs ficaram sentados em um círculo, ao redor de uma grande mesa retangular onde estavam acomodados os coordenadores da ESF (gerido pela prefeitura de um dos municípios). Eles eram chamados individualmente à mesa, na frente de todos, para mostrarem suas planilhas, que eram então checadas pelos coordenadores. Quando mal preenchidas, eram alvo de críticas públicas dos coordenadores, ou seja, gerava uma situação extremamente constrangedora para os agentes indígenas. Ademais, não havia por parte da coordenação qualquer iniciativa em explicar a importância ou a utilidade dos formulários.

As várias pesquisas indicam que a relação entre os profissionais indígenas e não indígenas da EMSI está marcada por ambiguidades que emergem da tensão entre um processo de trabalho hierárquico, definido por atividades burocráticas, e a dificuldade de compreensão e articulação entre maneiras diversas de tratar as questões relativas ao corpo, ao saudável, ao que é doença, ao puro/impuro, ao infortúnio, às dietas alimentares, às prescrições de hábitos etc. 12

Além dessas ambiguidades e tensões, é importante ressaltar que desde a implantação dos DSEIs um processo contínuo de formação e capacitação não tem sido efetivado, e a falta ou descontinuidade desses cursos em quase todos os distritos vem contribuindo também de modo negativo para o reconhecimento e a definição do papel do AIS. Por um lado, a falta ou escassez de cursos de capacitação para os agentes contribui para que os não indígenas das EMSIs avaliem os AISs como técnicos desqualificados (Marinho G Ott, 2007; Novo, 2009); por outro, os AISs reclamam que não têm palestras e cursos contínuos para ajudar a melhorar o atendimento dos problemas de saúde (Langdon et al., 2006). Assim, é a legitimidade ante a população indígena e os membros não indígenas das EMSIs que tem sido um ponto relevante nas expectativas de todos os atores envolvidos na atenção à saúde, e os cursos de capacitação teriam uma contribuição importante para o subsistema.

\section{Formação e Capacitação}

A implantação dos DSEIs e o aumento significativo de recursos financeiros para a saúde indígena possibilitaram uma política efetiva de contratação e incorporação do AIS na EMSI em nível nacional. Como parte dessa nova realidade, o processo de capacitação e supervisão dos agentes se torna mais centralizado e burocrático, dependendo do Desai/Funasa em Brasília para sua definição, 
financiamento e cronograma, cabendo aos distritos programar e executar os cursos. Se o aumento de contratações dos AISs significa um ponto positivo nos esforços da institucionalização de serviços diferenciados, a formação e a capacitação são, talvez, os aspectos mais fracos desses esforços. Apesar de a capacitação fazer parte da PNASPI desde a criação dos DSEIs, em 1999, as pesquisas revisadas mostram grandes lacunas na sua regularidade e continuidade e indicam que a supervisão do trabalho do AIS não ocorre como parte do processo pedagógico de ensino em serviço.

Rosângela Bissera (2006) relata uma interrupção na formação e participação dos índios como microscopistas e AISs quando houve em 2004 a troca da ONG indígena Urihi-Saúde Yanomami pela Fundação Universidade de Brasília no convênio com a Funasa. Quando a ONG Urihi-Saúde Yanomami assumiu o convênio com a Funasa em 1999, a malária foi identificada como o problema mais crítico de saúde nesse grupo. A ONG priorizou a formação de microscopistas indígenas como parte de um programa de treinamento dos AISs. Estes foram formados em sua própria língua (Yanomae, Yanomami e Sanumá) e se submeteram a um exame oficial na Secretaria de Saúde do Estado de Roraima, possibilitando a ampliação do combate à doença e sua redução entre os Yanomami. Junto com os agentes, que serviram primariamente como tradutores, eles foram vistos como importantes na interação com os membros não indígenas das equipes e com os Yanomami, especialmente como facilitadores dos serviços da EMSI (Bissera, 2006). Porém, com o fim do convênio com a ONG Uruhi em 2004, os microscopistas não foram mais contratados, não havendo continuidade da participação dos índios no combate à malária, tampouco dos processos de capacitação. ${ }^{13}$ A capacitação dos AISs foi retomada em 2005, tratando de tópicos como o conhecimento e funcionamento do corpo, noções de doença e contaminação, dentre outros, que, ignorando as formações anteriores, acabaram repetindo conhecimentos já dominados por alguns agentes.

Esron Rocha (2007) relata situação semelhante de repetição de conteúdos nos cursos de formação e capacitação para os AISs Baniwa e da insatisfação que essa situação gerou entre os indígenas. Após a implantação do DSEI Rio Negro em 2000, os cursos ofertados nos moldes preconizados pela Funasa, em módulos temáticos com períodos de concentração e dispersão, ignoraram as experiências de formação e capacitação realizadas anteriormente, ainda que os conteúdos fossem semelhantes. Segundo os dados coletados por Esron Rocha, desde 1990 até o ano 2000 foram realizados oito cursos de formação e capacitação por diferentes instituições, entre elas, Foirn, Centro de Saúde Escola Dom Walter Ivan da Diocese de São Gabriel da Cachoeira, Organização Indígena da Bacia do Içana (IBI), Rasi Universidade Federal do Amazonas e Coiab (Rocha, 2007). Após a distritalização, somente quatro cursos foram ofertados pela Funasa em convênios com a Foirn e com o Centro de Saúde Escola Dom Walter Ivan. Segundo Rocha (2007: 95), por meio de uma análise crítica 
dos avanços e limites nas propostas de formação realizadas até 2006, é possível destacar "a falta de um projeto pedagógico, o tecnicismo dos conteúdos, o reinício eterno das iniciativas dos cursos e a dificuldade em contemplar a especificidade da questão indígena".

No caso de Santa Catarina, o DSEI Interior Sul inicialmente promoveu dois cursos introdutórios, um em 2001 (direcionado a AIS e auxiliar de enfermagem) e outro em 2002 (somente para AIS do polo-base de Chapecó). Entre os 21 agentes que atuavam na TI Xapecó durante a pesquisa (Langdon et al., 2006), nove deles haviam participado dos cursos, e somente dois fizeram ambos. Na TI Ibirama-Laklãnõ, dos sete agentes que trabalhavam de fevereiro a outubro de 2004, três haviam cursado a capacitação de 2001. Em 2006, usando a proposta do Desai/Funasa de cursos no formato dos seis módulos, foram realizados dois deles no oeste de Santa Catarina. Na pesquisa de 2004, os AISs que participaram das capacitações não referiram espontaneamente tais cursos, sendo que disseram não se lembrar daqueles feitos em 2001 e 2002. Porém, esses e outros agentes citaram capacitações que trataram do uso de plantas medicinais, do preparo e uso da multimistura e da visita domiciliar, oferecidas de maneira esporádica pela Pastoral da Criança e também pela Secretaria de Estado do Desenvolvimento Social e da Família do Governo de Santa Catarina. Os agentes recém-contratados afirmaram que não receberam um curso de capacitação no momento de iniciar suas atividades, tendo tido apenas orientações quanto a um conjunto de atividades e uma breve explicação sobre a visita domiciliar. Diante da falta de capacitação contínua, o aprendizado dos novos AISs sobre o preenchimento dos numerosos formulários se dava com a ajuda dos colegas mais antigos ou eventualmente nas reuniões com a enfermeira da EMSI.

Marina Novo (2010a) também descreve a articulação, a comunicação e a troca de experiências entre os próprios AISs como forma de aprendizado, inclusive como fonte de estímulo para ingresso de outros indígenas nessa atividade. A autora revela que entre os agentes do Parque Indígena do Xingu (PIX) há uma valorização dessa forma de aprendizado, pois é marcado pelo conhecimento adquirido na prática, "o único jeito de aprender" (Novo, 2010a: 136). A valorização e o privilégio do aprendizado em serviço demostrado pelos AISs podem ser vistos como contrabalanço das características técnicas e qualidade dos poucos cursos de capacitação realizados.

A demanda por cursos de formação e palestras sobre temas específicos foi uma constante observada entre os Xokleng e Kaingáng de Santa Catarina. A ausência de cursos era indicada como motivo de insegurança no exercer cotidiano de suas práticas de atenção à saúde, assim como fonte de descrédito na eficácia de suas atividades e conselhos diante da população por eles atendida. Essa realidade estimulou vários AISs de ambas as TIs a realizarem cursos de técnico ou auxiliar de enfermagem por esforço próprio ou a terminarem o ensino médio com intenções de realizar tal curso. Ainda em Santa Catarina, por meio de uma solicitação de 
lideranças Kaingáng da TI Xapecó à Universidade Federal de Santa Catarina, foi criado o Projeto Pioneiro em 2001, que formou auxiliares e técnicos de enfermagem, muitos deles atuando em suas aldeias (Follmann, 2011). O mesmo movimento por melhores qualificações por meio de cursos profissionalizantes, como de técnico ou auxiliar de enfermagem, por exemplo, foi destacado por Georgia da Silva (2007) entre os Atikum. Da mesma forma, entre os Munduruku, o cargo de AIS é aparentemente visto como o início da carreira para jovens procurando posições mais profissionalizantes e técnicas (Silva, 2010). A iniciativa dos AISs em buscar sua profissionalização fora das TIs evidencia por si a necessidade do investimento na sua formação e, mais especificamente, evoca a reivindicação da certificação de nível técnico e do reconhecimento de sua profissão.

Como parte da centralização da Funasa, em 2005 os cursos desenhados pelos seus funcionários de Brasília foram oficialmente lançados no formato de seis módulos, intitulados Educação Profissional Básica para Agentes Indígenas de Saúde (Brasil, 2005), que trazem prioritariamente assuntos biomédicos e formação técnica. O primeiro módulo é uma introdução geral, e os restantes tratam da promoção à saúde e prevenção de parasitoses intestinais e doenças de pele; saúde do adulto e atenção às urgências; prevenção de doenças endêmicas; saúde da mulher, da criança e saúde bucal; e prevenção de DST/Aids.

A proposta de formação da Funasa por meio dos seis módulos mantém a perspectiva biomédica, sem considerar as diferenças culturais, as especificidades epidemiológicas e a escolarização dos AISs a serem formados, bem como as dificuldades que cada DSEI enfrenta (que envolvem questões organizacionais, financeiras e de gestão, entre outras) de programar e executar tais módulos. O curso completo foi organizado para durar três anos, dividido em 12 etapas - sendo necessários, portanto, 258 módulos para os 34 DSEIs. Analisando os módulos já ofertados, Raggio, Pinto e Morais (2009: 144) relatam que

em 2007, para o total de 3.833 agentes indígenas de saúde em curso de formação, foram concluídos 104 módulos, 40,3\% do total de 258 módulos programados. Foram realizadas 233 etapas do curso (sendo 129 concentrações e 104 dispersões), ou seja, 45,15\% de 516 no total. Em 25 módulos foi realizada somente a etapa de concentração e em 11 DSEI foi realizado apenas o módulo introdutório ou nenhum, ou seja, $32,35 \%$ dos 34 DSEI, ou $25,58 \%$ dos 43 cursos previstos. A maioria dos DSEI tem encontrado dificuldades para a realização dos módulos, principalmente as etapas de dispersão, que exigem a permanência dos instrutores/supervisores pedagogicamente capacitados e o funcionamento regular dos serviços, haja vista a realização de 129 concentrações e apenas 104 dispersões em todos os DSEI com o curso de formação. O curso de formação foi concluído oficialmente no DSEI Ceará, no segundo semestre de 2006, com uma turma de 14 AISs, e no DSEI Leste de Roraima, com a certificação de 372 AISs em abril de 2007. 
Esses dados, além de registrarem a ausência e a descontinuidade de cursos de formação para agentes indígenas, não permitem concluir se os AISs que fizeram os poucos cursos oferecidos permanecem no trabalho, visto a problemática trazida pela alta rotatividade, como já discutido aqui.

\section{Algumas Conclusões}

A PNASPI destaca a formação dos AISs como ponto central para promover uma atenção diferenciada, concebendo-o como elo entre os saberes tradicionais e biomédicos (Brasil, 2002a). É importante ressaltar que a definição das atividades e responsabilidades e a formação do AIS, entretanto, antecedem a implantação dos DSEIs em localidades específicas e estavam voltadas para a resolução de problemas também particulares (Xingu, Yanomami e Alto Rio Negro, por exemplo). Essas primeiras iniciativas buscaram, por meio de um processo pedagógico adequado, capacitar os indígenas para atividades em saúde levando em conta as especificidades epidemiológicas e culturais.

A partir do subsistema, em 1999, os AISs foram formalmente incorporados ao modelo de atenção, tendo a Funasa, em âmbito nacional, a responsabilidade de centralizar todo o processo de formação e capacitação. Essa centralização trouxe consequências nem sempre positivas, incluindo a desconsideração aos cursos anteriormente realizados, a proposição de módulos que predefinem os problemas de saúde e são pautados pela agenda dos grandes programas definidos pelo Ministério da Saúde e as estratégias pedagógicas guiadas pelos modelos ocidentais de ensino-aprendizagem. ${ }^{14}$

Após a implantação dos DSEIs e apesar da proposta político-sanitária acerca da concepção do papel do AIS, é possível destacar que sua função como mediador é marcado por conflitos e ambiguidades. A incorporação dos agentes indígenas na atenção primária é caracterizada principalmente pela possibilidade de acesso e distribuição de medicamentos e pela função de comunicação com a comunidade. Apesar de ser definido como um representante da comunidade que participa nos serviços e nas atividades de controle social, eles, como membros contratados da equipe, percebem que a Funasa é seu patrão e que são representantes de uma prática biomédica, criando uma situação de conflito de atuação. Para a comunidade, o AIS é um representante do serviço biomédico, e para os demais profissionais da EMSI, ele tornou-se um membro com atividades voltadas para o preenchimento de planilhas, a distribuição de medicamentos receitados e a comunicação de questões relativas aos serviços de saúde. Tais atribuições, como representante e assistente da equipe médica, contribuem para a ambiguidade do papel do agente indígena ante as demandas políticas que fazem parte da mediação entre saberes e processos 
decisórios. À medida que a falta de comunicação entre os AISs e o resto da equipe aumenta, essas ambivalências e conflitos aparecem com mais força.

$\mathrm{Na}$ rotina de trabalho, levando-se em conta a dinâmica hierárquica das relações entre os profissionais da EMSI, a alta rotatividade e a descontinuidade dos cursos de capacitação, o AIS é indicado como o membro mais despreparado tecnicamente para atuar juntamente com os demais profissionais, que, por sua vez, também reclamam de falta de capacitação para atuar em populações indígenas. Notamos ainda uma tensão entre a demanda da seleção dos AISs segundo os critérios da comunidade e os critérios técnicos exigidos pelo gestor.

Entende-se que não há uma discussão nem definição clara do conceito de atenção diferenciada. Nos documentos oficiais, atenção diferenciada é apresentada ambiguamente, por meio das noções de articulação, integração e incorporação das práticas tradicionais. As noções de integração e incorporação submetem as práticas tradicionais à determinação de eficácia medida pela epistemologia médica, implicando uma fragmentação instrumental dos sistemas indígenas de saúde, selecionando somente aquelas práticas comprovadas pelos parâmetros científicos.

Também se torna evidente que o processo de trabalho segue estruturado segundo a lógica da organização de serviços de saúde pautados pelo modo capitalista de produção, pela racionalidade burocrática, pela hegemonia do saber biomédico e pela hierarquia de cargos legitimados por um sistema e treinamento formal. Nesse contexto, o AIS ocupa uma posição subalterna.

Como solução para a posição subalterna e para a falta do reconhecimento da categoria agente indígena de saúde, Garnelo e colaboradores (2009) e Pontes, Stauffer e Garnelo (2012) ${ }^{15}$ relatam experiência de implantação de um curso de formação de AIS no Alto Rio Negro, como resultado da mobilização inicial da articulação entre lideranças indígenas e agentes. Diversas instituições estavam envolvidas nesse curso de formação com caráter técnico e profissionalizante, que se propõe também elevar a escolaridade formal dos alunos durante esse processo. A proposta do curso era formar e certificar 250 indígenas como agentes comunitários, categoria reconhecida pelo Ministério do Trabalho. Outra solução que observamos é a formação em técnico de enfermagem, como nos contextos do Parque Indígena do Xingu e em Santa Catarina entre os Xokleng e Kaingáng, com a diferença de que no primeiro caso a formação foi proposta pela conveniada com a Funasa e, no segundo, vários AISs buscaram a formação por sua própria conta.

É nesse contexto, somado às reivindicações do movimento indígena e das conferências nacionais de saúde indígena, que emerge a discussão sobre a profissionalização dos AISs e agentes indígenas de saneamento (Aisan), que foram incluídos em janeiro de 2010 como categorias profissionais na família de Agentes Comunitários de Saúde e Afins da Classificação Brasileira de Ocupação do Ministério do Trabalho e Emprego (Brasil, 2010a). Em que pesem as diretrizes apresentadas 
na PNASPI (Brasil, 2002a), até o momento o reconhecimento dos AISs e Aisan como profissionais da saúde, no que se refere tanto à formação/capacitação quanto ao vínculo e aos seus papéis, ainda está sem resolução na prática, um desafio a ser superado pela Secretaria Especial de Saúde Indígena (Sesai) (Brasil, 2010b), que assume toda a responsabilidade anteriormente atribuída à Funasa. ${ }^{16}$

Positivamente, podemos afirmar que a Funasa se dedicou à contratação de agentes indígenas em número maior a cada ano. O aumento de contratados como AIS deve ser visto como importante no processo da implantação do subsistema. O AIS faz parte da reivindicação central das organizações indígenas na constituição da PNASPI para maior participação nos serviços de saúde, sendo também um importante recurso de renda e prestígio nos processos sociais e políticos comunitários. Aliás, como destacado neste capítulo, em muitas situações o AIS é o único profissional da EMSI presente na aldeia.

\section{Notas}

1 Versão no formato de artigo foi publicada por Eliana Elisabeth Diehl, Esther Jean Langdon e Raquel Paiva Dias-Scopel (2012).

2 Cada distrito deve contar nas terras indígenas com uma rede de serviços para a atenção primária, e o acesso às estruturas assistenciais de média e alta complexidades, localizadas fora dos territórios indígenas, deve se dar idealmente de forma articulada e pactuada com os gestores municipais e estaduais.

3 As pesquisas em Santa Catarina cumpriram todas as exigências ético-legais, recebendo pareceres favoráveis do Comitê de Ética em Pesquisa com Seres Humanos da Universidade Federal de Santa Catarina (UFSC) e da Comissão Nacional de Ética em Pesquisa (Conep), além das autorizações para ingresso em terra indígena, expedidas pela Fundação Nacional do Índio.

4 Antes de 2011, o gestor da saúde indígena era a Fundação Nacional de Saúde (Funasa); a partir de então está sob a responsabilidade da Secretaria Especial de Saúde Indígena (Sesai).

5 O PSF foi reorientado como Estratégia Saúde da Família (ESF). Neste capítulo, utilizaremos a designação ESF.

6 Essa lei foi revogada em 2006 pela lei n. 11.350/2006, que trata das atividades dos ACS e dos agentes de combate às endemias. O reconhecimento como profissional da saúde é mantido, sendo submetido ao regime jurídico da Consolidação das Leis do Trabalho. Disponível em: <http://pesquisa.in.gov.br/imprensa/jsp/visualiza/index.jsp?jornal=1Gpagina=1Gdata $=06 / 10 / 2006>$. Acesso em: 23 jul. 2014.

7 Reconhecemos que os missionários e suas organizações têm desempenhado um papel importante na provisão de serviços de saúde antes da criação dos DSEIs. Esther Jean Langdon e Eliana E. Diehl serviram de assessoras de projetos envolvendo o Cimi e a Comissão Pró-Índio 
(CPI), alguns com estratégias pedagógicas inovadoras. A partir de 1978, o Cimi organizou uma série de encontros de saúde, que incluíram o tema do AIS e suas atribuições com o objetivo de orientar as ações em saúde (Araújo, 2006).

8 Preparado à base de cereais, folhas, sementes e casca de ovo, destinado à complementação alimentar, principalmente de desnutridos.

9 A Cosai remunerou os AISs em pequena escala, mas essa responsabilidade passou para o Programa Nacional de Agentes Comunitários de Saúde do Ministério da Saúde (Confalonieri G Verani, 1993).

10 A terra indígena Xapecó está localizada no território de dois municípios no oeste do estado de Santa Catarina.

11 De modo semelhante, Ferraz e Aerts (2005), em seu estudo sobre os ACSs de Porto Alegre (RS), observaram que as atividades administrativas obrigatórias desses agentes, como organizar pastas e prontuários e preencher as fichas do Sistema de Informação de Atenção Básica (Siab), eram consideradas por eles desagradáveis.

12 De modo semelhante, Víctora, Knauth e Oliveira (2008) indicam que a ambiguidade do papel do ACS, em um estudo de caso em Porto Alegre (RS), expressa-se também por meio da relação hierárquica na equipe de saúde e é relativa à distância social, cultural e econômica que cerca o ACS e os demais membros dessa equipe.

13 Uma consequência foi a volta da alta incidência de malária na região.

14 Para uma comparação entre os AISs mais antigos que trabalharam como ACSs antes do Subsistema de Saúde Indígena e os AISs das EMSIs, ver Silva (2010), que revela outras consequências negativas do processo de centralização.

15 Ver também Santos e Daniel (2012).

16 Ver Santos e Daniel (2012) e Pontes, Stauffer e Garnelo (2012) para discussões mais recentes sobre a questão de formação.

ARAÚJO, M. Do Corpo à Alma: missionários da Consolato e Índios Macuxi em Roraima. São Paulo: Fapesp, Associação Editorial Humanitas, 2006.

ARGENTINO, S. Rio Negro (1996-2000). In: BITTENCOURT, M. et al. (Orgs.). Acre, Rio Negro e Xingu: a formação indígena para o trabalho em saúde. São Paulo: Associação Saúde sem Limites, 2005.

BISSERA, R. S. Ainda Estamos Vivos: uma etnografia da saúde Sanumá, 2006. Tese de Doutorado, Brasília: Programa de Pós-Graduação em Antropologia, Universidade de Brasília. 
BITTENCOURT, M. G TOLEDO, M. E. Acre (1989-1994). In: BITTENCOURT, M. et al. (Orgs.). Acre, Rio Negro e Xingu: a formação indígena para o trabalho em saúde. São Paulo: Associação Saúde sem Limites, 2005.

BITTENCOURT, M. et al. Acre, Rio Negro e Xingu: a formação indígena para o trabalho em saúde. São Paulo: Associação Saúde sem Limites, 2005.

BRASIL. Constituição da República Federativa do Brasil, 1988. Disponível em: <www.planalto.gov.br/ccivil_03/constituicao/constituicao.htm>. Acesso em: 12 ago. 2014.

BRASIL. Ministério da Saúde. Fundação Nacional de Saúde. Formação de Agentes Indígenas de Saúde: proposta de diretrizes. Brasília: Fundação Nacional de Saúde, 1996a. (Mimeo.)

BRASIL. Lei n. 9.394, de 20 de dezembro de 1996. Estabelece as Diretrizes e Bases da Educação Nacional. Diário Oficial [da] República Federativa do Brasil, Brasília, DF, 23 dez. 1996b.

BRASIL. Ministério da Saúde. Fundação Nacional de Saúde. Formação de Agentes Indígenas de Saúde. Brasília: Fundação Nacional de Saúde, Departamento de Operações, Coordenação de Saúde do Índio, 1999. (Mimeo.)

BRASIL. Ministério da Saúde. Conselho Nacional de Saúde. $3^{a}$ Conferência Nacional de Saúde Indígena: relatório final. Brasília: Conselho Nacional de Saúde, 2001. Disponível em: <http://189.28.128.100/dab/docs/geral/3cnsi.pdf. >. Acesso em: 13 ago. 2014.

BRASIL. Ministério da Saúde. Fundação Nacional de Saúde. Política Nacional de Atenção à Saúde dos Povos Indígenas. 2. ed. Brasília: Fundação Nacional de Saúde, 2002a.

BRASIL. Lei n. 10.507, de 10 de julho de 2002. Cria a profissão de Agente Comunitário de Saúde e dá outras providências, 2002b. Disponível em: <http://dtr2004.saude.gov.br/ susdeaz/legislacao/arquivo/14_Lei_10507.pdf>. Acesso em: 13 ago. 2014.

BRASIL. Ministério da Saúde. Fundação Nacional de Saúde. Educação Profissional Básica para Agentes Indígenas de Saúde. Brasília: Fundação Nacional de Saúde, 2005. Disponível em: <www.lexml.gov.br/urn/urn:lex:br:federal:lei:2002-07-10;10507>. Acesso em: 13 ago. 2014.

BRASIL. Classificação Brasileira de Ocupações. 3. ed. Brasília: MTE, SPPE, 2010a.

BRASIL. Decreto n. 7.336, de 19 de outubro de 2010. Aprova a Estrutura Regimental e o Quadro Demonstrativo dos Cargos em Comissão e das Funções Gratificadas do Ministério da Saúde, e dá outras providências, 2010b. Disponível em: <www.planalto.gov.br/ccivil_03/_Ato2007-2010/2010/Decreto/D7336.htm>. Acesso em: 9 maio 2011.

CONFALONIERI, U. E. C. G VERANI, C. L. Agentes indígenas de saúde. In: CONFALONIERI, U. E. C. (Org.). Saúde de Populações Indígenas: uma introdução para profissionais de saúde. Rio de Janeiro: Escola Nacional de Saúde Pública Sergio Arouca/Fundação Oswaldo Cruz, 1993.

DIAS-SCOPEL, R. P. O Agente Indígena de Saúde Xokleng: por um mediador entre a comunidade indígena e o serviço de atenção diferenciada à saúde - uma abordagem da antropologia da saúde, 2005. Dissertação de Mestrado, Florianópolis: Programa de Pós-Graduação em Antropologia Social, Universidade Federal de Santa Catarina. 
DIAS-SCOPEL, R. P.; LANGDON, E. J. G SCOPEL, D. Expectativas emergentes: a inserção do agente indígena de saúde Xokleng na equipe multidisciplinar de atenção à saúde indígena. Revista Tellus, 13: 51-73, 2007.

DIEHL, E. E. Entendimentos, Práticas e Contextos Sociopolíticos do Uso de Medicamentos entre os Kaingang (Terra Indígena Xapecó, Santa Catarina, Brasil), 2001. Tese de Doutorado, Rio de Janeiro: Escola Nacional de Saúde Pública Sergio Arouca, Fundação Oswaldo Cruz.

DIEHL, E. E.; LANGDON, E. J. G DIAS-SCOPEL, R. P. Contribuição dos agentes indígenas de saúde na atenção diferenciada à saúde dos povos indígenas brasileiros. Cadernos de Saúde Pública, 28(5): 819-831, 2012.

ERTHAL, R. M. C. A formação do agente de saúde indígena Tikúna no Alto Solimões: uma avaliação crítica. In: COIMBRA JR., C. E. A.; SANTOS, R. V. G ESCOBAR, A. L. (Orgs.). Epidemiologia e Saúde dos Povos Indígenas no Brasil. Rio de Janeiro: Editora Fiocruz, 2003.

FERRAZ, L. G AERTS, D. R. G. C. O cotidiano de trabalho do agente comunitário de saúde no PSF em Porto Alegre. Ciência G Saúde Coletiva, 10(2): 347-355, 2005.

FOLLMANN, H. B. C. Indígenas como Trabalhadores da Enfermagem: o papel de técnicos e auxiliares no modelo de atenção à saúde indígena, 2011. Dissertação de Mestrado, Florianópolis: Programa de Pós-Graduação em Saúde Coletiva, Universidade Federal de Santa Catarina.

FUNDAÇÃO NACIONAL DE SAƯdE (FUNASA). Relatório das Principais Atividades e Resultados 1999-2002, 2002. Disponível em: <www.funasa.gov.br/site/wp-content/ uploads/2011/10/relatorio_1999_2002.pdf>. Acesso em: 13 ago. 2014.

FUNDAÇÃO NACIONAL DE SAÚDE (FUNASA). Programa de Formação para Agentes Indígenas de Saúde, 2006. Disponível em: <www.neppi.org/gera_anexo.php?id=509>. Acesso em: 13 ago. 2014.

FUNDAÇÃO NACIONAL DE SAÚDE (FUNASA). Agentes indígenas de saúde, 2007. Disponível em: < www.funasa.gov.br/site/wp-content/files_mf/blt_abr_2009.pdf> . Acesso em: 13 ago. 2014.

GARNELO, L. Projeto Rede Autônoma de Saúde Indígena: uma experiência de educação e comunicação em saúde indígena. In: VASCONCELOS, E. M. (Org.). A Saúde nas Palavras e nos Gestos: reflexões da Rede Educação Popular e Saúde. São Paulo: Hucitec, 2001.

GARNELO, L. Poder, Hierarquia e Reciprocidade: saúde e harmonia entre os Baniwa do Alto Rio Negro. Rio de Janeiro: Editora Fiocruz, 2003.

GARNELO, L.; MACEDO, G. G BRANDÃO, L. C. (Orgs.). Os Povos Indígenas e a Construção das Políticas de Saúde no Brasil. Brasília: Organização Pan-Americana da Saúde, 2003.

GARNELO, L. et al. Formação técnica de agente comunitário indígena de saúde: uma experiência em construção no Rio Negro. Trabalho, Educação e Saúde, 7(2): 373-385, 2009.

HELMAN, C. Cultura, Saúde e Doença. 4. ed. Porto Alegre: Artes Médicas, 2003. 
INSTITUTE OF DEVELOPMENT STUDIES/SAÚDE SEM LIMITES/CENTRO BRASILEIRO DE ANÁLISE E PLANEJAMENTO (IDS/SSL/CEBRAP). Diagnóstico Situacional do Subsistema de Saúde Indígena: relatório inicial (revisado). Brasília: IDS/SSL/Cebrap, 2009.

KRENAK, A. et al. Documento final da Conferência Nacional de Proteção à Saúde do Índio. Saúde em Debate, n. esp.: 60, 1988. (Revista do Centro Brasileiro de Estudos de Saúde) Disponível em: <http://docvirt.com/asp/acervo_cebes.asp?Bib=SAUDEDEBATEGPAS$\mathrm{TA}=\mathrm{N} .+$ especial\%2C + edi\%E7\%E3o + especialGpesq $=\mathrm{Gx}=72 \mathrm{G} \mathrm{y}=8>$. Acesso em: 13 ago. 2014.

LANGDON, E. J. G DIEHL, E. E. Participação e autonomia nos espaços interculturais de saúde indígena: reflexões a partir do sul do Brasil. Saúde e Sociedade, 16: 19-36, 2007.

LANGDON, E. J. G ROJAS, B. G. Saúde: um fator ignorado numa situação de mudança rápida - a situação da Área Indígena Ibirama (SC). Boletim de Ciências Sociais, 51: 65-89, 1991.

LANGDON, E. J. et al. A participação dos agentes indígenas de saúde nos serviços de atenção à saúde: a experiência em Santa Catarina, Brasil. Cadernos de Saúde Pública, 22(12): 2.637-2.646, 2006.

MARINHO, G. L. G OTT, A. T. Agentes Indígenas de Saúde de Rondônia: um estudo etnográfico (relatório preliminar). Porto Velho: Programa Institucional de Bolsas de Iniciação Científica (Pibic), Universidade de Rondônia/Centro de Estudos de Saúde Indígena de Rondônia (Cesir)/CNPq, 2007.

MENDONÇA, S. B. M. O Agente Indígena de Saúde no Parque Indígena do Xingu, 1996. Dissertação de Mestrado, São Paulo: Programa de Pós-Graduação em Ciências Sociais, Pontifícia Universidade Católica de São Paulo.

MENDONÇA, S. B. M. O agente indígena de saúde do parque indígena do Xingu: reflexões. In: BARUZZI, R. G JUNQUEIRA, C. (Orgs.). Parque Indígena do Xingu: saúde, cultura e história. São Paulo: Unifesp, Terra Virgem, 2005.

MOROSINI, M. V. G. C. A Política de Formação dos Agentes Comunitários de Saúde: memória de uma formulação em disputa nos anos 2003-2005, 2009. Dissertação de Mestrado, Rio de Janeiro: Programa de Pós-Graduação em Saúde Coletiva, Instituto de Medicina Social, Universidade do Estado do Rio de Janeiro.

NOVO, M. P. Saúde e interculturalidade: a participação dos agentes indígenas de saúde/AISs do Alto Xingu.R@U: Revista de Antropologia da UFSCar, 1(1): 122-147, 2009.

NOVO, M. P. Os Agentes Indígenas de Saúde no Alto Xingu. Brasília: Paralelo 15/ABA, 2010a.

NOVO, M. P. Um papel de fronteira e seus (não) espaços: os agentes indígenas de saúde do Alto Xingu. In: FLEISCHER, S.; TORNQUIST, C. S. G MEDEIROS, B. F. (Orgs.). Saber Cuidar, Saber Contar: ensaios de antropologia e saúde popular. Florianópolis: Udesc, 2010b.

OLIVEIRA, L. S. S. Formação e Inserção Institucional de Agentes Indígenas de Saúde no Sistema Único de Saúde: um estudo de possibilidades, 2002. Tese de Doutorado, São Paulo: Faculdade de Saúde Pública, Universidade de São Paulo. 
OLIVEIRA, L. S. S. O agente indígena de saúde do Parque Indígena do Xingu: perspectivas de formação e trabalho. In: BARUZZI, R. G JUNQUEIRA, C. (Orgs.). Parque Indígena do Xingu: saúde, cultura e história. São Paulo: Unifesp, Terra Virgem, 2005.

OLIVEIRA, M. C. Os Curadores Kaingang e a Recriação de suas Práticas: estudo de caso na aldeia Xapecó (Oeste de SC), 1996. Dissertação de Mestrado, Florianópolis: Programa de Pós-Graduação em Antropologia Social, Universidade Federal de Santa Catarina.

ORGANIZAÇÃO INTERNACIONAL DO TRABALHO (OIT). Convenção n. 169 sobre Povos Indígenas e Tribais em Países Independentes e Resolução Referente à Ação da OIT sobre Povos Indígenas e Tribais. 2. ed. Brasília: OIT, 2005 [1989]. Disponível em: <http://www. mds.gov.br/segurancaalimentar/povosecomunidadestradicionais/indigenas/documentos/ Convencao\%20no169.pdf/view>. Acesso em: 13 ago. 2014.

PONTES, A. L.; STAUFFER, A. G GARNELO, L. Profissionalização indígena no campo da saúde: desafios para a formação técnica de agentes indígenas de saúde. In: GARNELO, L. G PONTES A. L. (Orgs.). Saúde Indígena: uma introdução ao tema. Brasília: MEC-Secadi/ Unicef, 2012.

RAGGIO, A.; PINTO, N. G MOR, P. Análise da gestão. In: INSTITUTE OF DEVELOPMENT STUDIES. SAÚDE SEM LIMITES. CENTRO BRASILEIRO DE ANÁLISE E PLANEJAMENTO (IDS/SSL/CEBRAP). Diagnóstico Situacional do Subsistema de Saúde Indígena: relatório inicial (revisado). Brasília: IDS/SSL/Cebrap, 2009.

RECH, P. A Supervisão na Formação Profissional de Agentes Indígenas de Saúde no Parque Indígena do Xingu, 2008. Dissertação de Mestrado, São Paulo: Faculdade de Saúde Pública, Universidade de São Paulo.

ROCHA, C. C. Adoecer e Curar: processos da sociabilidade Kaingáng, 2005. Dissertação de Mestrado, Florianópolis: Programa de Pós-Graduação em Antropologia Social, Universidade Federal de Santa Catarina.

ROCHA, E. Uma Etnografia das Práticas Sanitárias no Distrito Sanitário Especial Indígena do Rio Negro - Noroeste do Amazonas, 2007. Dissertação de Mestrado, Manaus: Programa de Pós-Graduação em Sociedade e Cultura na Amazônia, Universidade Federal do Amazonas.

SANTOS, E. F. G DANIEL, L. Educação escolar indígena e suas interfaces com o campo da saúde. In: GARNELO, L. G PONTES, A. L. (Orgs.). Saúde Indígena: uma introdução ao tema. Brasília: MEC-Secadi/Unicef, 2012.

SCOPEL, D. Saúde e Doença entre os Índios Mura de Autazes (Amazonas): processos socioculturais e a práxis da autoatenção, 2007. Dissertação de Mestrado, Florianópolis: Programa de Pós-Graduação em Antropologia Social, Universidade Federal de Santa Catarina.

SILVA, C. D. C. Saúde e Política: uma etnografia dos profissionais da saúde indígena, 2010. Tese de Doutorado, Brasília: Programa de Pós-Graduação em Antropologia Social, Universidade de Brasília.

SILVA, G. "Chama os Atikum Que Eles Desatam Já": práticas terapêuticas, sabedores e poder, 2007. Dissertação de Mestrado, Recife: Programa de Pós-Graduação em Antropologia, Universidade Federal de Pernambuco. 
SOUZA, N. M. S. F; CALVACANTE, M. S. G BRANDÃO, M. C. Agentes de saúde indígena: realidades pluriétnicas e experiências de formadores. In: BRANDÃO, M. C.; PAULA, N. C. G ATHIAS, R. (Orgs.). Saúde Indígena em São Gabriel da Cachoeira (AM): uma abordagem antropológica. Recife: Liber Gráfica e Editora, 2002.

TEIXEIRA, C. C. Fundação Nacional de Saúde: a política brasileira de saúde indígena vista através de um museu. Etnográfica, 12(2): 323-351, 2008.

VIANNA, J. J. B. G OTT, A. M. T. Agentes indígenas de saúde no DSEI Porto Velho: um estudo etnográfico. Pesquisa e Criação - Revista de Divulgação do Pibic/Unir, 5: 2007.

VÍCTORA, C. G.; KNAUTH, D. R. G OLIVEIRA, F. A. A ambiguidade dos agentes comunitários de saúde: análise de uma experiência pioneira. In: CAROSO, C. (Org.). Cultura, Tecnologias em Saúde e Medicina: perspectiva antropológica. Salvador: EdUFBA, 2008.

WAWZYNIAK, J. V. Assombro de Olhada de Bicho: uma etnografia das concepções e ações em saúde entre ribeirinhos do Rio Tapajós, Pará - Brasil, 2008. Tese de Doutorado, São Carlos: Programa de Pós-Graduação em Antropologia, Universidade Federal de São Carlos.

WORLD HEALTH ORGANIZATION (WHO). Declaration of Alma-Ata - International Conference on Primary Health Care, Alma-Ata, USSR, 1978. Disponível em: <www.who. int/publications/almaata_declaration_en.pdf >. Acesso em: 21 set. 2009. 


\section{Cultura, Sexualidade e Saúde Indígena: etnografia da prevenção das DST/Aids nos povos Timbira do Maranhão e do Tocantins ${ }^{1}$}

A relação entre sexualidade e povos indígenas forma um cenário histórico polêmico e polissêmico, que aguça a atenção de muitas pessoas. No contexto brasileiro, a relação entre sexualidade, colonialismo e minorias étnicas torna claros o local e o papel dos povos indígenas no imaginário mais amplo de nosso país. Por exemplo, muitos brasileiros contam que suas avós foram pegas a laço no mato, descrevendo uma situação dos indígenas como arredios, selvagens e bárbaros, sendo que a violência e sua relação com os casamentos interétnicos ocupariam um espaço ainda pouco visualizado etnograficamente.

Ao se transportar essa relação descrita para um cenário contemporâneo, como as epidemias de DST/Aids, surge um campo fértil para destrinchar analiticamente as imbricadas conexões entre sexualidade, cultura e poder, por meio de uma experiência etnográfica na atenção à saúde indígena no Brasil. O vírus HIV, ponto de partida deste capítulo, pode ser visto como um quase objeto (Latour, 1993), ${ }^{2}$ pois ele condensa elementos que podem ser paulatinamente descobertos, em um caminho para maior compreensão do modo como a saúde indígena brasileira é empiricamente realizada, assim como das dificuldades para que esse processo seja feito de forma diferenciada, tal como preconizado pelas legislações brasileiras e acordos internacionais dos quais somos signatários.

A pandemia da Aids faz parte do cotidiano urbano brasileiro desde a década de 1980, aparecendo como um dos principais temas de saúde pública no país. Presente em discussões técnico-epidemiológicas, ela é também matéria em revistas e jornais onde famosos contribuíram na visualização desse tema ao se assumirem como soropositivos ou por se posicionarem a favor dos direitos sociais desse grupo. Apesar de tanta exposição e de uma vasta produção acadêmica em múltiplas áreas de conhecimento, abordando desde aspectos epidemiológicos e de reprodução viral até questões sociais, é facilmente aceito que existem lacunas importantes a serem superadas para melhor compreensão do fenômeno social do HIV/Aids no Brasil.

O processo de interiorização e expansão da epidemia no Brasil, tendência em nosso país, conduz a reflexão para um campo aparentemente inusitado: como 
essa epidemia atinge os povos indígenas e como tais povos apropriam-se dessa temática, situando-a em seus próprios sistemas de mundo e conjunturas sociais.

Com este capítulo, pretendo suprir, parcialmente, essas lacunas ao propor uma etnografia da problemática global do HIV/Aids em uma perspectiva localizada: o olhar singular que os povos Timbira, seis grupos indígenas que vivem nos cerrados do norte do Tocantins e do sul do Maranhão, têm sobre a epidemia da Aids. A etnografia está assentada na minha experiência pessoal de sete anos de trabalho com os Krahô, um dos povos Timbira, e três anos como antropólogo do Programa Timbira, do Centro de Trabalho Indigenista (CTI). Dois desses anos foram dedicados à coordenação do Projeto Controle Social em DST/Aids pelos Índios Timbira do Maranhão e Tocantins, financiado pelo Programa Nacional de DST/Aids do Ministério da Saúde, por meio do Edital de Organizações da Sociedade Civil de 2004.

Em linhas gerais, o projeto que coordenei consistia em colaborar para a formulação de políticas públicas de saúde indígena com a avaliação dos riscos e da vulnerabilidade de seis povos indígenas que vêm sendo denominados, desde a clássica análise de Curt Nimuendaju (1971), como Timbira. Além disso, havia a formação de multiplicadores indígenas responsáveis por repassar informações a suas aldeias e da assessoria técnica necessária à consolidação do Departamento de Saúde da Associação Wyty Catë das Comunidades Timbira do Maranhão e Tocantins. A contribuição viria justamente no aspecto mais frágil da atenção à saúde indígena no Brasil: como efetivamente obter caminhos criativos para que esse processo de atenção à saúde seja culturalmente diferenciado.

Situar-se entre as esferas de fortalecimento do movimento indígena dos povos Timbira, assim como colaborar com ações direcionadas a enfrentar o aumento das DST e a proximidade com casos de Aids diagnosticados nos municípios do entorno das Terras Indígenas (TIs) dos Timbira, formou um tenso campo interétnico e de diálogos, ora mais truncados/nervosos, ora mais construtivos/colaborativos entre as comunidades indígenas, os profissionais da saúde e os gestores da atenção à saúde indígena. Aqui exploro etnograficamente esse encontro de perspectivas de mundos extremamente distintas entre si desde o processo saúde/doença/enfermidade sobre HIV/Aids, formando espaços interétnicos com suas contradições, riquezas e diferenças.

\section{Os Povos Timbira e o Subsistema de Saúde Indígena}

Para analisar os modos como os povos Timbira enfrentam a problemática das DST em suas aldeias, assim como a da proximidade do HIV/Aids de suas terras indígenas, é necessário precisar os contornos do que possa ser essa categoria social Timbira e articular as múltiplas realidades locais que cada um desses povos 
vivencia no Maranhão e no Tocantins. Ela não é uma expressão local, mas de algum modo encontra ressonâncias no conceito interno de mehin, o termo como os povos Timbira se autodenominam. ${ }^{3}$ Esse conceito pode ser traduzido, de forma livre, como "aqueles que possuem a minha carne", ou "os que compartilham uma mesma substância entre si". É um conceito que remete ao ideal desses grupos indígenas sobre o que é humanidade e quais são seus critérios de sociabilidade. Ao mesmo tempo, é um dos pilares fundamentais da diferenciação étnica e do seu reconhecimento como uma unidade formada, mas certamente não homogênea, que se distingue dos demais grupos indígenas e da população não indígena.

Do ponto de vista histórico, o nome Timbira designa diversos grupos indígenas do sul do Maranhão e do norte do Tocantins, os principais responsáveis pelas resistências à expansão colonial nessa região, fato somente superado no século XIX. Em comum, esses povos falam uma mesma língua, compartilham mitos e rituais, suas aldeias têm a mesma espacialidade e sociabilidade de acordo com seus próprios padrões. Atualmente, os que resistiram à violenta expansão colonial nesses sertões são os povos Krahô e Apinajé, no estado do Tocantins, e os Krikati, Gavião Pyhcobjê, Apanjekra-Canela, Ramkokamenkra-Canela e Krepynkatejê no estado do Maranhão, existindo ainda os Parkatejê, que, ao recusarem o contato, migraram para as matas a oeste, e hoje estão no Pará.4

A maior parte das TIs dos grupos Timbira foi oficialmente reconhecida pelo governo federal; para estas, as questões fundiárias estão resolvidas. Ali, o desafio atual parece dizer respeito à gestão territorial nas áreas demarcadas, onde a saúde indígena surge como um dos elementos centrais.

A uniformidade social reconhecida pela literatura, pela poesia e pela etnografia passou ao largo quando houve o processo de distritalização da saúde indígena no Brasil. Em vez de a atenção à saúde indígena desses grupos ser organizada em um território étnico sanitário único como Distrito Sanitário Especial Indígena (DSEI), o processo que imperou foi a divisão político-geográfica baseada segmentação por unidade federada. Assim, os Timbira foram fracionados em três DSEIs distintos Tocantins, Maranhão e Guama-Tocantins -, e uma série de conflitos e problemas passou a afetar esses grupos.

O que fica claro é a existência de um processo socialmente construído de invisibilidade da condição una desses grupos indígenas no momento de implementação do subsistema, o que trouxe dificuldades de operacionalização de uma atenção à saúde indígena realmente diferenciada. Equipes multidisciplinares não conseguem ser formadas plenamente, em parte pela alta rotatividade de pessoal, em parte pela interferência de gestores municipais na sua composição. Uma invisibilidade política que vem sendo sistematicamente rechaçada pelas organizações indígenas representativas dos povos Timbira, especialmente a Associação Wyty Catë, das comunidades Timbira do Maranhão e do Tocantins, que pressiona há 
anos o Departamento de Atenção à Saúde Indígena para a criação de um distrito próprio e autônomo.

Os povos Timbira, de maneira geral, têm enfrentado problemas graves no processo de atenção à saúde indígena em suas comunidades. Os que estão no Maranhão convivem em um distrito com sérias dificuldades de organização, tendo uma estrutura de atenção à saúde precária nas aldeias, estimulando o encaminhamento e o referenciamento para atendimento nas cidades próximas ao invés de fortalecer a resposta básica nas aldeias.

No Tocantins, esses povos enfrentam um problema nítido de presença de DST em suas aldeias, uma precariedade no sistema de segurança alimentar do grupo, presença esparsa das equipes multidisciplinares de saúde indígena (EMSIs) nas suas aldeias e fortes conflitos pelo abuso de bebidas alcoólicas. Em comparação com o Maranhão, a capacidade de resposta do DSEI Tocantins é bem mais estruturada, mas o ponto-chave de ambos terem uma dificuldade de gestão está no processo de formação desses distritos. Em vez de atentarem para as especificidades etnoculturais como critério de definição dos espaços territoriais que formariam os distritos, no caso dos DSEIs Maranhão e Tocantins, prevaleceu o critério político e geográfico. Como resultado, há dificuldades e complexidades derivadas de inserção de povos com modos diferenciados de se organizarem e uma multiplicidade de sistemas de governança que resulta em controles sociais extremamente precários - com altos graus de interferência política nas diretrizes técnicas, nas equipes multidisciplinares e o reflexo nas estratégias de atenção à saúde indígena.

Em ambos os distritos, assim como em diversos contextos no Brasil, o controle social não funciona de maneira adequada. O que percebo é que, em parte, há um interesse político em que os conselhos de saúde desses distritos não funcionem bem, em uma estratégia de manutenção do controle sobre as populações indígenas, em um processo de poder colonial com um deslocamento da noção de tutela do indigenismo oficial para o campo da saúde indígena.

Em razão desses fatores, os povos Timbira do Maranhão e do Tocantins tiveram que lidar com o hipermetropia dos gestores de saúde indígena no processo de definição e implantação dos DSEIs. A hipermetropia é uma deficiência visual comum que gera a dificuldade de enxergar objetos próximos. A unidade Timbira, que estava tão próxima e fácil de ser percebida, pereceu em nome de questões e interesses políticos que forçaram a divisão dos DSEIs em uma ótica político-estadual. ${ }^{5}$ 


\section{DST/Aids, Intermedicalidade e Saúde nos Povos Timbira do Maranhão e do Tocantins}

O Subsistema de Saúde Indígena tem o dever e a tarefa de trabalhar questões relacionadas com a prevenção, a atenção e o tratamento das DST/Aids nas aldeias, assim como planejar e desenvolver atividades de educação e de promoção da saúde indígena. A diferença cultural inerente à rotina dos integrantes do subsistema fica explicitamente ressaltada quando a abordagem envolve as complexas relações entre sexualidade e cultura. O caso específico dos povos Timbira do Maranhão e do Tocantins revela esses choques, estranhamentos e percepções distintas entre os processos de saúde, doença e enfermidade que existem entre esses povos e os agentes do subsistema.

Há uma zona de intermedicalidade que envolve os diferentes agentes com uma consciência sociomédica em conflitos, confrontos e oposições justamente por vivenciarem empiricamente os dilemas desses encontros interculturais sobre os processos de saúde, doença e enfermidade. A definição conceitual de zona de intermedicalidade, construída por Maj-Lis Fóller baseada nas análises de Shane Greene (1998), circunscreve um espaço sociocultural definido em que:

tal zona seria um espaço contextualizado de medicinas híbridas e agentes com consciência sociomédica. No discurso colonial do poder, dominação e conhecimentos médicos legítimos são enfatizados. A intermedicalidade faz parte do discurso em que ocorrem confrontos, posições e conflitos. (Fóller, 2004: 133-134)

Os estudos que abordaram os problemas etnográficos encontrados nas zonas de intermedicalidade compostas pelos agentes sociais que vivenciam a atenção à saúde indígena dos povos Timbira do Maranhão e do Tocantins têm concentrado o foco de suas análises nos confrontos e conflitos entre agentes indígenas de saúde (AISs) e pajés, ${ }^{6}$ por um lado, e os técnicos de enfermagem e médicos, por outro (Nimuendaju, 1971; Melatti, 1963, 1967, 1972, 1978). Essas dimensões importantes revelam pontos sugestivos etnograficamente de como a saúde indígena é empiricamente negociada e efetuada nos krin (aldeias), fornecendo uma contribuição interessante que deveria transcender os círculos acadêmico-antropológicos e ser incorporada ou minimamente conhecida pelos profissionais do Subsistema de Saúde Indígena.

Todavia, essas mesmas análises não têm dado o mesmo peso a outros atores com consciência sociomédica (indígenas e não indígenas) que participam ativamente dessas zonas de intermedicalidade. Do lado indígena, mencionam brevemente os fatores que motivam pais/mães, avós, amigos formais e tios a intervirem no processo de cura e exigir processos complexos de negociações que definem o itinerário tera- 
pêutico dos pacientes. Do lado biomédico, essas etnografias não costumam indicar os fatores que levam os gestores dos gabinetes nas sedes dos distritos em Palmas (TO) e São Luís (MA) a formular seus programas e ações que compõem os planos distritais, havendo uma lacuna etnográfica sobre os profissionais da saúde em ação.

Contribuir para suprir aspectos das lacunas é um dos objetivos que pretendo alcançar neste capítulo, ao menos do ponto de vista de uma análise sobre como os povos Timbira transitam criativamente nessa zona de intermedicalidade. Afirmo isso porque o tema das DST/Aids, no contexto dos povos Timbira, está menos circunscrito aos trabalhos dos curadores indígenas (pajés) e mais centrado nos processos de negociação familiar cujos atores já mencionei aqui. Os dados de campo revelam que essa questão não é comumente associada a quebras de tabus e normas sociais e/ou ataques de mecarón (espíritos) cujo tratamento é um trabalho específico dos curadores indígenas. Pelo contrário, a emergência de uma DST é vista como fruto de práticas individuais e o processo saúde/doença/enfermidade é associado aos contatos interétnicos. Sua intervenção terapêutica está muito mais ligada aos conhecimentos fitoterápicos individuais e familiares do que a ações dos curadores indígenas.

Aqui trabalho com o conceito de zona de intermedicalidade, mas em vez de concentrar os esforços em explorar os conflitos e divergências interculturais, minha intenção é etnografar os possíveis diálogos entre sistemas médicos distintos, revelando possibilidades reais de articulação. Parece que nossa sociedade entende a articulação de sistemas médicos como uma tarefa difícil e quase impossível (mesmo que ela seja preconizada nas legislações nacionais), ${ }^{7}$ contudo para os povos Timbira parece ser possível fazer essa articulação, só que ela é difícil de ser realizada por causa do poder colonial que empodera saberes dos agentes do Subsistema de Saúde Indígena e descredencia - e em muitos casos ridiculariza - os saberes tradicionais de cura e promoção da saúde.

O desafio etnográfico que proponho aqui não está tanto em revelar os conflitos intermédicos e os choques de perspectivas (o que vem sendo feito em artigos, dissertações de mestrado e teses de doutorado na área da antropologia da saúde no Brasil), mas sim analisar criticamente a agencialidade e a criatividade indígenas em articular os sistemas médicos e - mais ainda - perceber em que medida os choques derivam da assimetria de poder e subjugação da cultura indígena ante os saberes biomédicos, revelando os processos coloniais e modos como essa hierarquia de poder é construída e internalizada nas ações de atenção à saúde indígena. A hierarquia de poderes persiste na conjuntura das relações interétnicas brasileiras, e a saúde indígena certamente é o espaço no qual o indigenismo (Ramos, 1998) se expõe de maneira mais nítida.

A zona de intermedicalidade dos povos Timbira não só possibilita medicinas híbridas como cria zonas de interfluxos criativos em que os dois sistemas 
médicos estão em um jogo de diferenças e semelhanças. Ao se contrastarem e se chocarem, acabam por reforçar suas identidades e preceitos. Tanto o sistema biomédico como o indígena - ao menos no contexto dos povos Timbira do Maranhão e do Tocantins - alimentam-se um do outro, pois é no encontro desses sistemas que suas eficiências e deficiências são percebidas e testadas pelos atores sociais. Em vez de se pensar em entidades estancadas e separadas se chocando (medicina indígena x biomedicina), o esforço aqui é etnografar a criatividade desse encontro, sobretudo em uma situação de risco e vulnerabilidade das TIs dos povos Timbira do Maranhão e do Tocantins ante a interiorização da epidemia de HIV/Aids e o aumento das DST em suas aldeias.

\section{Vulnerabilidade e Risco das DST/Aids nos Timbira}

O estado do Tocantins e o sul do Maranhão têm sido alvos de políticas públicas de desenvolvimento regional e nacional, com ênfase em fomento de infraestruturas importantes para uma orientação comercial e industrial, como construção de ferrovias (ferrovia Norte-Sul); hidrovia (a possibilidade da hidrovia Araguaia-Tocantins); aproveitamento hidroelétrico com a construção da UHE Estreito (com impacto sobre os Krahô, Apinajé, Krikati e Gavião Pyhcobjê) e a possibilidade de empreendimentos dessa natureza como Serra Quebrada (afetando os Apinajé) e Tupiratins (com impactos diretos sobre os Krahô); o asfaltamento e a ampliação da malha rodoviária da região (como as estradas estaduais que cortam as TIs Krikati e Apinajé). Essa rede de infraestrutura tem fomentado o desenvolvimento de atividades agroindustriais como os plantios de soja no entorno das TIs Krahô, Porquinhos (Apanjekra-Canela) e Escalvado (Ramkokamekra-Canela), ou ainda o recente polo de produção de celulose no Piauí, no Tocantins e no sul do Maranhão, que modificará o cenário no entorno dos Apinajé, Krikati e Gavião-Pyhcobjê.

Essas obras de infraestrutura levam novas situações aflitivas para um cenário de alto risco e vulnerabilidade ante as DST/Aids - com a chegada de migrantes, o aumento de trânsito pela região, a facilidade de mobilidade, o aumento do fluxo de indígenas nas cidades, a atração de empreendimentos industriais para uma região rural e o incremento do assédio para atividades produtivas ambientalmente desgastantes no interior das TIs.

O Tocantins é um estado cortado pela rodovia Belém-Brasília em sentido sul-norte, o que representa uma via de transmissão do HIV, e em suas margens concentram-se cidades com altos índices de soropositivos, como Araguaína e Wanderlândia. Ao mesmo tempo, o estado já atende indígenas soropositivos do povo Javaé, mas a atenção nesses contextos não está sob responsabilidade do DSEI Tocantins. O sul do Maranhão tem em Imperatriz a segunda cidade com maior 
número de casos de soropositivos no estado, sendo essa cidade o principal polo urbano do sul maranhense, com alto fluxo de indígenas dos povos Timbira, como Krikati e Gavião-Pyhcobjê, e também de Guajajara. ${ }^{8}$ Barra do Corda é outra cidade com muitos casos e com uma alta circulação de indígenas Apanjekra-Canela e Ramkokamekra-Canela, além de Guajajara. ${ }^{9}$

Esse quadro ganha maior complexidade quando se percebe que as ações de prevenção das DST/Aids, apesar de contarem com a boa vontade dos profissionais da saúde indígena, não se baseavam em sólidos conhecimentos sobre a relação entre sexualidade e cultura nesses povos, ficando sempre restritos ao senso comum dos membros da EMSI. Por exemplo, na época do projeto que coordenei, havia um cartaz no Polo Base Goiatins (que atende os Krahô) que dizia: "Não adianta lavar os órgãos genitais com Coca-Cola, mesmo assim pega Aids". Isso não significava muito para os Krahô que liam esse cartaz e que, em comentários pessoais comigo, mostravam-se impressionados, rindo muito com o suposto fato de as cupenkoj (mulheres não indígenas) lavarem seus órgãos genitais com refrigerante. Em outra ocasião, eu estava na aldeia Porquinhos, do povo Apanjekra-Canela, e fui informado pelas técnicas de enfermagem de como eram as atividades de educação em saúde sobre DST/Aids: eram dadas palestras nas aldeias, com um número muito baixo de participantes. O mesmo fato verifiquei na aldeia Pedra Branca, do povo Krahô, no Tocantins, o que me leva a considerar que essa estratégia de palestras informativas é levada em diferentes contextos e resulta em um mesmo fato: pouquíssima adesão de indígenas e quase nenhum efeito pragmático.

A falta de conhecimentos específicos sobre a cultura dos povos indígenas é uma carência dos distritos sanitários de maneira geral. No caso das DST/Aids, isso é ainda mais significativo porque todo o trabalho desenvolvido não se articula com a cultura desses povos - amplificando a sua vulnerabilidade ante as DST/Aids, porque o próprio subsistema não está preparado para realizar o diálogo intercultural sobre um tema tão sensível, complexo e difícil de ser abordado.

A avaliação da situação de vulnerabilidade e risco dos povos Timbira do Maranhão e do Tocantins desenvolvida pelo Projeto Controle Social em DST/Aids pelos povos Timbira do Maranhão e do Tocantins, coordenado por mim, levou em conta não apenas a identificação e a análise de fatores externos como os aqui descritos e o histórico de contato. Para além desses procedimentos, foram realizadas análises minuciosas dos fatores internos, como os aspectos culturais envolvidos na questão de sexualidade, cultura e processos de saúde, doença e enfermidade, tais como: iniciação sexual, festas e rituais, imaginário sobre camisinha, mitologia e outros. Além disso, o projeto também avaliou os fatores institucionais, como a capacidade de resposta do Subsistema de Saúde Indígena, a infraestrutura física e recursos humanos disponíveis nesses povos e a articulação com as esferas municipais e estaduais responsáveis pela atenção à saúde. Não há espaço para descrever 
em detalhes todos esses fatores; serão mencionados apenas alguns aspectos. Enfatizarei fatores internos para sublinhar como o conhecimento sobre a relação entre sexualidade e cultura indígena é um dos pontos centrais para o enfrentamento e o planejamento de ações contra DST/Aids.

\section{O Projeto Controle Social em DST/Aids pelos Índios Timbira}

O Projeto Controle Social em DST/Aids pelos índios Timbira do Maranhão e do Tocantins foi uma parceria de uma organização não governamental indigenista, o Centro de Trabalho Indigenista (CTI), com uma organização indígena, a Associação Wyty Catë das Comunidades Timbira do Maranhão e Tocantins. Foi a primeira iniciativa em saúde indígena que se propôs a abordar esses povos como um conjunto social e étnico que, apesar das singularidades locais, conta com aspectos que contornam uma mesma configuração social. Esses aspectos são a história do contato interétnico, a língua, a espacialidade da aldeia, os inúmeros rituais e ritos, os mitos, dentre outros. O que os gestores da saúde não quiseram ver no processo de distritalização da atenção à saúde indígena, a Wyty Catë se propôs a suscitar por meio dessa discussão.

O foco do CTI, nesse caso, era proporcionar a assessoria técnica necessária para uma demanda cada vez mais crescente na Associação Wyty Catë: um departamento de saúde para dialogar diretamente com os órgãos governamentais responsáveis pelo processo de atenção à saúde indígena no Brasil. O projeto tinha, então, o objetivo de fomentar o controle social dos índios Timbira do Maranhão e do Tocantins, capacitar trinta membros do grupo em direitos indígenas e saúde, além de realizar levantamentos antropológicos e participativos sobre vulnerabilidade e risco das seis TIs desses povos nos dois estados.

Em um contexto no qual os AISs não faziam capacitação há anos e com crescentes problemas de atenção à saúde, não foi difícil para cada aldeia indicar pessoas para participar do projeto junto com a Associação Wyty Catë. Foram efetuadas reuniões em todas as aldeias Krikati, Gavião-Pyhcobjê, Apanjekra-Canela e Ramkokamekra-Canela, assim como nas principais aldeias Krahô e Apinajé. Lá, no meio do kä (centro da aldeia) - espaço tradicional para as discussões políticas -, eram indicados jovens para participar das capacitações propostas, bem como estabelecidos os termos para os levantamentos antropológicos participativos previstos no projeto.

Uma das preocupações que se tinha na ocasião era encontrar estratégias para incorporar mulheres no projeto, especialmente em razão dos altos índices de jovens diagnosticadas com problemas uterinos (muitas foram operadas antes dos 30 anos) e da dificuldade em participar dos exames de prevenção de câncer de 
colo do útero, mesmo nas aldeias. Para tanto, foi necessário alargar o número de participantes de trinta para quarenta indígenas, já que os maridos das mulheres escolhidas não permitiam que elas fossem desacompanhadas, sugerindo que eles participassem dos cursos. O projeto teve a flexibilidade para se adaptar a essas situações e construir uma metodologia para o trabalho com saúde da mulher. Um resultado inesperado foi que, com o andamento do curso, as mulheres participantes dos povos Krahô e Apinajé foram contratadas como AISs. ${ }^{10}$

\section{Sexualidade, Cultura e Diálogos Interculturais}

Se a situação no entorno era preocupante e o Subsistema de Saúde Indígena não estava preparado para enfrentar os problemas em todos os níveis de atenção, o que mais preocupava os coordenadores indígenas da Associação Wyty Catë eram os aspectos culturais internos. Os povos Timbira costumam ser diretos e brincalhões quando falam sobre sexualidade e a relação entre os aminjkin e o ato de namorar. Nas suas festas rituais não podem, idealmente, ter ciúmes uns dos outros, e é nesses momentos em que pode haver relações extramatrimoniais, já que indígenas de várias aldeias deslocam-se até o local de realização da festa tradicional.

Saúde e cultura estão interligadas no mundo Timbira, como mostra a relação entre sexualidade, cultura e atenção à saúde indígena, especialmente sobre DST/Aids. As festas tradicionais são momentos em que casais de jovens namoram, seja de noite na cantoria no centro da aldeia, seja de dia nas corridas de tora em volta da aldeia. Nesses momentos de festas rituais, como em qualquer festa, ocorre a possibilidade de transmissão de DST no circuito entre as aldeias, uma porta aberta para a disseminação do vírus, caso haja algum indígena infectado com HIV. ${ }^{11}$ Isso de forma alguma significa que a cultura local seja um caminho escancarado para a disseminação dessas moléstias, mas sim que os profissionais/agentes de atenção à saúde indígena devem estar preparados para lidar com tais aspectos culturais e realizar as negociações que propiciem a efetivação da atenção diferenciada.

Conversas sobre sexo e brincadeiras de duplo sentido são habituais publicamente, sem assumir o caráter de algo proibido ou vergonhoso. Na festa da batata-doce (yot-yõ-pin), em que os indígenas correm com toras de jatobá ou outras madeiras de lei (em vez das corriqueiras de buriti), imediatamente antes de iniciar a corrida os meninos são colocados em fila; um dos velhos da aldeia passa por eles e examina o pênis dos rapazes, separando os muito jovens dos que já podem pensar em namorar. A sexualidade não é vista como algo privado a ser escondido; vi numa das aldeias um grupo de jovens assistindo a um filme pornográfico por volta das dez horas da manhã. No local, estavam pessoas de diversas idades, inclusive a mulher mais velha da casa, com mais de 80 anos, que ficava dizendo que os cupen 
(não indígenas) são sebosos e que praticam sexo como animais (sexo oral). É mais um ponto da diferenciação entre os cupen e os mehin, em que os primeiros, em vários aspectos, não compartem os atributos mínimos de uma sociabilidade ideal, não dividem seus bens, são individualistas, não têm consideração pelos familiares e suas regras sociais são esquisitas aos olhos indígenas.

Em diversos rituais, as questões de relacionamento extramatrimonial também aparecem simbolicamente em ação nos rituais. Lembro-me de uma ocasião nos Krahô em que estava ocorrendo uma festa de iniciação dos jovens - pempcahök-e depois de uma noite inteira de cantorias no centro da aldeia, com os jovens reclusos na casa dos pemp, seus kéti (tios e nomeadores, ou seja, homens mais velhos que atribuem nomes aos iniciandos) iam até essa casa, colocavam os jovens nos ombros e os levavam ao centro da aldeia. Um indígena disse que poderia haver brigas entre mulheres ciumentas, quando indaguei o motivo. Ele sorriu e disse que nessa hora os copais (os homens que ajudaram a fazer a criança) são chamados pelas mães e, em caso de um deles ser casado, sua esposa pode ficar inkruc (brava). Tal situação realmente aconteceu e, em poucos segundos após seus comentários, duas mulheres se atracaram, sendo apartadas pelos parentes. Em outras festas, como a da laranja, a mulher tem que jogar laranjas nos seus parceiros sexuais da aldeia, explicitando possíveis relacionamentos extraconjugais.

O argumento que sustento é o de que a sexualidade é algo natural para os povos Timbira, que não compartilham da perspectiva cristã do sexo como algo pecaminoso. Ao contrário, o sexo é associado aos momentos prazerosos da convivência humana e, mesmo em casos de ciúmes e traições descobertas, tudo pode ser resolvido em um processo de vendeta, com o traidor tendo que doar bens para o traído, em um sistema de dádivas.

Os processos sociais ligados à primeira relação sexual das meninas surgem como mais um dos pontos das diferenças culturais e das relações entre famílias em uma aldeia. No mundo krahô a família e a cultura, de certa maneira, influenciam uma iniciação sexual cedo, pois a primeira menstruação não indica um corpo pronto para a vida sexual, mas um corpo já sexualmente ativo. Conforme a tradição local, a menarca (primeira menstruação) é considerada um sinal de que a menina já teve relações sexuais, e a ela deve apontar aquele com quem manteve relações para que seja feita a cobrança dos dotes. Uma jovem Krahô me confessou que escondeu que tinha menstruado durante quatro meses, porque ainda era virgem, e, se sua mãe descobrisse, ela teria que indicar quem foi o homem com quem ela tivera relações sexuais, sendo que nos casos mais sérios a situação pode chegar ao ka (pátio central da aldeia).

Os Timbira seguem o princípio da uxorilocalidade, ou seja, após o casamento, o rapaz reside na casa de sua sogra e sogro, passando a trabalhar mais tempo na roça dessa família do que na sua casa de origem. Toda essa linha de esforços e 
recursos é deslocada, portanto, da casa de origem do rapaz para a casa da família de sua esposa, no desempenho daquilo que a literatura etnológica convencionou chamar de serviço do genro, evento presente em boa parte dos povos ameríndios nas terras baixas sul-americanas. Este é inicialmente um de fora que paulatinamente será agregado. Perdurando o casamento, a tendência é que ele venha a ser sogro, quando suas filhas estiverem casadas e com filhos.

No mundo Timbira, é facultado às mulheres o direito de receber alguma contrapartida, em bens e recursos, dos seus parceiros sexuais. Esse ato, contudo, não deve ser visto como prostituição/pagamento segundo nossos padrões, na medida em que nem as mulheres nem os homens acham esse costume pejorativo ou desmoralizador da mulher. São eventos que devem ocorrer na condição de uma mulher mehcreker, mulher solteira que assume um papel social específico que tem entre suas características manter um comportamento sexual livre e gozar de elevado reconhecimento na aldeia por sua condição - o que não é uma qualidade intrínseca a uma pessoa, mas sim um estado que aquela pessoa está vivendo naquele momento. Ela pode, perfeitamente, deixar de ser mehcreker.

Interessante é notar que os próprios Timbira dizem que suas mulheres gostam de namorar o cupen porque ele tem mais poré (dinheiro) e mais poder de conseguir os bens. Entretanto, há pouquíssimos casamentos de mulheres brancas com homens indígenas dos povos Timbira, embora isso não signifique inexistência de relações sexuais entre mulheres não indígenas com homens indígenas, o que evidentemente acontece. Nas festas de cupen, em grande maioria, os homens das cidades e dos povoados vizinhos é que vão para a aldeia dançar forró. Essa questão de gênero (homem branco com mulher indígena) é associada à exclusão social, dificuldade de acesso aos bens industrializados, preconceito e discriminação contra os índios. Pobreza e exclusão social são articuladas pelos próprios Timbira como uma das explicações das relações entre cupen (não indígenas) e mehin (indígenas).

O sexo, portanto, não é de forma alguma somente um ato biológico, mas assume uma dimensão social que conecta pessoas e famílias em um sistema de reciprocidade, de união de corpos e de (re)produção humana do ponto de vista tanto biológico como social. Uma criança não pode ser gerada no útero da mulher somente por uma relação sexual. Aliás, o nome para útero entre os povos Timbira é cahãexy, o que eu traduzo - de forma livre e com todo o risco de erro e má interpretação como o local em que ocorrem as alterações na mulher. ${ }^{12}$ Os rituais revelam essa visão local do sexo como algo prazeroso, das relações extramatrimoniais como algo comum no cotidiano da sociabilidade local e do ciúme (hõkraitı) como um aspecto humano desvalorizado.

É possível estender essa descrição etnográfica das diferenças culturais do modo de encarar a sexualidade como um aspecto que singulariza esses povos perante os outros grupos indígenas e não indígenas da região. Seguramente, isso 
extrapola os objetivos do presente capítulo. Vale lembrar, todavia, que a traição está presente em um mito que explica a forma como esses povos aprenderam o poder de cura (o mito de Tyrkren). Nele é relatado que uma mulher trai o marido, que está muito doente, com o irmão dele. Ainda segundo o mito, o marido, ao ser levado aos céus pelos urubus, vê a esposa no ato da traição com seu próprio consanguíneo. Quando ele retorna dos céus para a aldeia e passa a ter o poder de se transformar e metamorfosear em outros animais e seres, sua mulher lhe diz que está grávida. Ele sabe que o filho não é seu, pois tinha espiado sua mulher tendo relações sexuais com o irmão. Nesse momento, o marido traído se transforma em uma formiga e fere o pênis de seu irmão. Feridas no órgão genital e traições estão associadas a esse mito do primeiro xamã dos povos Timbira, em uma analogia simbólica entre adultério e doenças nos órgãos genitais.

Uma das estratégias adotadas pelos profissionais do Subsistema de Saúde Indígena em diferentes contextos distritais é o estabelecimento de uma cota mensal de distribuição de preservativos que ficam à disposição na aldeia. Eu acompanhei a chegada de um jovem Apanjekra-Canela ao posto de saúde da aldeia para pedir preservativo à técnica de enfermagem, mas certamente isso não é um hábito muito comum; não me lembro de outra vez ter visto ou ouvido algum comentário a esse respeito em nenhum dos povos Timbira. Nos levantamentos antropológicos do Projeto Controle Social em DST/Aids pelos índios Timbira do Maranhão e do Tocantins, as imagens culturalmente construídas sobre esse novo objeto que os cupen utilizam foi um dos pontos centrais que levantei em campo, verificando que há um enorme desconhecimento dessas imagens pelos profissionais da saúde. Em vez de se informarem sobre as imagens e os conceitos locais que os indígenas atribuem ao HIV/Aids, outras DST e à camisinha, esses profissionais, geralmente, ignoram esses aspectos, considerando-os prova de um desconhecimento dos povos indígenas.

Ao trazer aspectos das imagens culturalmente construídas dos povos Timbira sobre a camisinha, pretendo mostrar como pequenos detalhes podem fazer uma grande diferença em um trabalho de educação em saúde, em contextos de alteridade forte e marcante como no caso dos povos indígenas aqui estudados. ${ }^{13}$

Eu sou casado, mas gosto de usar camisinha. Quando saio para algum lugar, é importante. Eu sou casado, mas posso usar quando vou para algum lugar. Eu não uso com minha mulher porque ela não gosta de usar. Mas me preocupo de usar fora do casamento, e como eu não posso ver quem tem a doença, eu me protejo... (Homem Apinajé, 19 anos)

Tinha uma amiga de outra aldeia. Minha amiga já ouviu falar de camisinha, mas nem usou. Ela não sabia usar. Eu ensinei ela a usar. Ela não se acostumou ainda, mas vai se acostumar. Quando eu fui em uma festa, tinha o cantor da banda de 
forró. Ele queria namorar com uma menina. Eu chamei minha amiga, que foi falar com ele. Não tinha camisinha, mas ela foi arrumar uma e daí sim as coisas aconteceram. (Mulher Apinajé, 15 anos)

A utilização desses depoimentos é muito mais do que um mero mecanismo para ilustrar; é um caminho para que se possa ir descortinando as capas de imagens socioculturais que existem sobre a camisinha, tal qual os diferentes povos Timbira postulam. Nesse processo de descortinar essas capas e dar visibilidade a questões que antes estavam circunscritas ao indivíduo e sua família, destaco como os laços familiares e o parentesco são ferramentas importantes para o processo de atenção e promoção à saúde indígena. Os medos, angústias, prazeres e desejos que aparecem cotidianamente nas aldeias são revelados subitamente nessas entrevistas, feitas na língua indígena e posteriormente traduzidas.

Os depoimentos mostram que o itinerário de uma DST em aldeias Timbira tem um comportamento perceptível ao se analisarem os casos e/ou os acompanhamentos de pessoas infectadas e tratadas que guardam lembranças nas suas memórias. Os amnjkin, as festas de forró, as bebedeiras nas aldeias e nas cidades, a relação de pobreza e subjugação à qual estão submetidos os Timbira, tudo isso é passível de ser mapeado, criando uma cartografia das DST/Aids nos povos Timbira do Maranhão e do Tocantins, em que aspectos do sistema médico desses povos estão relacionados com a questão da sexualidade e cultura.

Na nossa aldeia, todos nós sabemos de doenças comuns, mas não sobre Aids. Assim como essa doença que o branco chama de Aids, tem outras na nossa aldeia, como febre, tosse, dor de cabeça, dor de estômago. Tem gonorreia e outras também. Sei que com camisinha não pega essas doenças, mas aqui tem DST. Um parente meu já teve mehytyt (gonorreia). Dentro da aldeia não tem posto de saúde e nem remédio dos brancos, só remédio do mato mesmo. Foi isso que ajudou a curar meu parente. Tem mulher aqui que vai para Amarante do Maranhão e fica dez dias por lá. A gente sabe que o povo da cidade usa ela, quem sabe ela não tem doença também? (Mulher Gavião-Pyhcobjê, 20 anos)

Há uma heterogeneidade nos imaginários dos diferentes povos Timbira com relação à camisinha que revela também os modos e intensidades dos contatos desses povos com a sociedade envolvente. As terras indígenas dos Apinajé, Krikati e Gavião-Pyhcobjê estão bastante próximas das cidades do entorno, com estradas que facilitam em muito o fluxo de não indígenas nas aldeias e de indígenas nas cidades.

Em geral, com as mulheres, aconteceu como nesse trecho de entrevista transcrito: a entrevistadora era mulher, e mesmo assim a entrevistada estava muito nervosa; as duas falavam baixinho, de modo quase imperceptível. Esse tipo de questão se verificou bastante nos Apanjekra-Canela, Ramkokamekra-Canela e 
Krahô, sendo que nos Krikati, Gavião-Pyhcobjê e Apinajé as mulheres indígenas que eram pesquisadoras do projeto tinham maior desenvoltura.

Eu nunca vi e nem usei a camisinha. Mas quem sabe um dia eu vou usar. Eu sei que meu marido gosta de andar por aí, e se ele não usar ele traz doença para mim... (Mulher Krahô, 26 anos)

Eu já usei alguma vez. Não é sempre que eu uso, não, mas eu gosto de usar porque nem peguei kraré [filho] e nem pega doença nenhuma. Também gostei porque não vai me melar nada, não. Foi assim que aconteceu... (Mulher Krahô, 15 anos)

Os trabalhos e entrevistas feitos pelos homens, geralmente, eram mais densos; em suas conversas, falavam mais e tinham mais desenvoltura.

A camisinha é bom porque no tempo dos velhos não existia esta camisinha e agora está tendo isto. $O$ homem e a mulher novo namora com o cupen, rapaz novo namora e gosta do cupen. O homem que não sabe usar a camisinha sai por aí e faz sexo sem a camisinha, não está sabendo de nada e encontra cupen bêbada e se cupen quiser transar ele não pensa, transa mesmo.

A primeira vez era assim, fode sem camisinha, e eu acho muito bom porque não tem nadinha. Eu acho ruim quando pega a doença, fico com vergonha de falar com minha aldeia e não acho bom. Tem o me cacô [gonorreia] e também o me hür [outra DST] porque faz sexo com cupen e pega estas doenças. Os índios gostam dos brancos também, mas eu não gosto de namorar com cupen, não. Sabe por quê? Porque eu não sei perguntar para ela, não sei chegar nela...

Sei que posso usar para não ter filho e se eu saio e minha mulher aceita outro homem ela não pega nem filho dele e nem traz doença para mim. Eu pego a camisinha, uso em outra mulher e não levo nada para casa. Assim eu fiquei sabendo, mas sei pouco sobre Aids... (Homem, 28 anos)

Eu sei colocar a camisinha e fiz uma vez com ela. Era uma mulher negrinha do sertão mesmo. Eu sei colocar mesmo [havia sido questionado pelo entrevistador] experimentei uma vez só mesmo e fez medo também. Eu tenho medo que a camisinha pode matar meu ixôt [pênis] e acabar com ele... Isto faz medo no índio... (Homem, 25 anos)

Eu penso muito sobre a camisinha. Acho importante, mas para mim não é bom, não. $O$ que eu sei é que eu posso usar, mas só porque o outro fala. Mas tenho medo de ela estourar [caton... o mesmo termo de espingarda e estrondo, que causa pavor nas mulheres de sentirem isto] dentro das mulheres. Será que pode acontecer algo com este estouro dentro dela? Tenho medo deste estouro e nunca usei. Continuo viajando muito mesmo e eu gosto mais é de mexer com a mulher daqui da aldeia mesmo... (Homem, 32 anos) 
Como visto, há imaginários sociais distintos que devem ser trabalhados nas ações de educação e saúde voltadas para conscientização, sensibilização e informação para que se evitem as DST/Aids. Estourar a camisinha é uma metáfora inofensiva para nós, mas os Timbira podem interpretá-la como um fenômeno barulhento e que causa medo.

Sobre os fluidos corporais, os povos Timbira nomeiam o sangue de caprô. Via de regra, entre eles, existe a ideia de que as pessoas com sangue próximo - e que por isso compartilham uma mesma substância vital - não podem se casar nem devem ter relações sexuais entre si. Pessoas ligadas pelo nome, chamadas na literatura etnográfica de "amigos formais", também não devem ter relações sexuais (Melatti, 1978; Croker, 2004). Os Timbira frequentemente utilizam para marcar as pessoas a quem eles estão ligados o termo kwa e o traduzem como parente. ${ }^{14}$ As representações que os povos indígenas fazem do sangue, fluidos corporais, formação da vida, transmissão das doenças ainda carecem de maior aprofundamento e pesquisas antropológicas. Mas no caso dos Timbira, pela vasta literatura antropológica e etnográfica existente, é possível verificar pontos sugestivos.

O sangue é uma substância potencialmente perigosa e transmissora de doenças. Seu manejo deve ser cuidadoso. Antigamente, os homicidas deviam cumprir um rigoroso resguardo para limpar seu corpo após ter entrado em contato com o sangue do morto.

O sangue menstrual é alvo de severas restrições sexuais. Os homens Timbira não mantêm relações com mulheres menstruadas, acreditam que podem adoecer. As mulheres menstruadas não devem sair muito das casas, não devem olhar roças, porque sua condição pode fazer as plantas murcharem. Não podem se banhar com as demais pessoas, pois seu sangue as contaminará. ${ }^{15}$

Os líquidos, especialmente a água, são tidos como um dos mecanismos de transformação dos corpos. O mito que narra o surgimento da primeira mulher criada entre os Timbira afirma que ela foi feita com uma cabaça dentro da água. A água tem uma participação fundamental em vários ritos. Essa simbologia sobre a água pode ser deslocada para o sêmen - chamado pelos Timbira de (h)nim. Esse termo também designa carne e está na autodenominação do grupo (mehin), marcando sua humanidade e diferença. Essa ligação aponta para um entendimento do sêmen como portador de substanciais vitais e formadoras das pessoas.

Os povos Timbira concordam com seus pressupostos tradicionais de que é preciso uma quantidade boa de sêmen para que um corpo possa ser formado, o que envolve muitas relações sexuais. Portanto, é uma visão radicalmente diferente da visão ocidental de construção e formação do feto e dos corpos. Para nós, uma única relação sexual é capaz de gerar uma vida. Para os Timbira, não é possível a formação dos corpos sem muita quantidade de sêmen. Se uma mulher procura outros parceiros sexuais durante a gravidez, estes também serão tidos como pais da 
criança. A formação das pessoas no útero da mãe (cahãe xy) é análoga à formação social das pessoas por meio dos numerosos rituais de passagem: ambas são um processo lento e demorado que tem de ser repetido muitas vezes.

Os Timbira valorizam o aleitamento materno até a criança atingir os 4 ou 5 anos e consideram absurdo as práticas das mulheres da cidade grande, que recusam amamentar seus filhos por mais de seis meses. Amamentar é um orgulho para as mães, criando os laços de intimidade com seus filhos, que ficam muito próximos delas.

As noções de parentesco Timbira possibilitam que um indivíduo tenha várias mães, ou seja: várias mulheres assumem esse papel, e as irmãs de sua mãe biológica são tratadas pelo mesmo termo designado para mãe (inxê). Pelas regras sociais dos Timbira, as mulheres de uma mesma família (mãe, filhas e irmãs) acabam por residir próximas umas das outras, formando o que a literatura etnográfica denominou de segmento residencial (Melatti, 1978). Todas essas mulheres amamentam um bebê, independentemente se é velha ou nova ou se amamenta outra criança. Assim, as pessoas de uma aldeia, notavelmente aquelas com laços de parentesco considerados mais próximos, vão trocando fluidos corporais (leite materno) e participando no fortalecimento e crescimento das crianças.

Os Timbira são extremamente ativos em suas manifestações culturais e valorizam seus rituais e a necessidade deles na formação social de seu povo. Mesmo nos dias atuais, o tempo em suas aldeias é mensurado também pelo ciclo de festas tradicionais. Existem festas grandes de fertilidade, colheita e iniciação dos jovens. Uma aldeia Timbira, tanto faz se é a dos Krahô, Krikati ou Canela, está sempre preocupada com seus rituais, com as corridas e preparações das próximas festas. Nessas festas, sempre se ouve um dos velhos dar conselhos à aldeia, gritando que é dia de festa e que quem vir o seu parceiro namorando outra pessoa não deve brigar, pois é um dia de alegria para a comunidade.

Como o contato histórico com os não indígenas é muito antigo, com mais de duzentos anos, os povos Timbira incorporaram algumas festas cristãs, sempre regadas a comida, reza, cachaça e forró, dando-lhes significados e singularidades próprias. São como elos sociais com os sertanejos e moradores regionais que, nos últimos anos, têm aumentado o convite para os seus amigos moradores das cidades do entorno de sua área. Os povos Timbira adotaram várias cerimônias dos regionais, principalmente as festas de santo e as juninas. Fazem a Festa de São Pedro (29 de junho), como uma espécie de dia do branco: todos se vestem de cupen (não indígena), com sapatos e roupas novas, e as mulheres usam saia e batom. Essas festas têm a presença de homens do entorno das TIs, mas poucas mulheres comparecem. Os índios ficam dançando forró e bebendo com os não indígenas, e os homens passam a noite com as índias. É nesses encontros festivos que acontecem muitos namoros e relações sexuais com os cupen, e como a cachaça é praticamente obrigatória e 
consumida em grandes quantidades, há confusão, brigas e risco de transmissão de DST. Vários depoimentos nas aldeias relatam que a DST age em ciclos, e que estes começam geralmente dias depois de um amikin ou festa em outra aldeia. ${ }^{16}$

\section{A Zona de Intermedicalidade como Expressão da Agencialidade Timbira}

$\mathrm{O}$ vírus HIV, como um quase objeto, autorizou um processo analítico que foi fruto de uma experiência antropológica e etnográfica dos impactos possíveis de epidemias de DST/Aids entre os povos Timbira e os processos de agencialidade desses povos em construir seu futuro, serem ouvidos nas políticas públicas e serem atores participativos fundamentais no processo de construção de uma atenção à saúde diferenciada em suas comunidades.

A zona de intermedicalidade desse cenário transcorrido no sul do Maranhão e norte do Tocantins certamente revela suas tensões interétnicas, mas um olhar atento ao modo como os povos Timbira lidam com essa situação em cada contexto local revela caminhos possíveis de articulações de sistemas médicos para a efetivação de políticas de atenção à saúde efetivamente diferenciadas. A zona de intermedicalidade tratada é um panorama sobre as relações entre culturas indígenas, poder colonial, indigenismo e atenção à saúde indígena, uma área fértil para o desenvolvimento de pesquisas de campo e que ainda necessitam ser etnografadas.

O que discuto neste capítulo são apenas fragmentos do universo muito particular dos povos Timbira do Maranhão e do Tocantins e do modo como a transmissão de DST é entendida por eles. Mesmo que tenha sido um pequeno trecho de uma investigação que ainda deverá ser feita, ela já revela a complexidade do processo de atenção à saúde indígena no contexto brasileiro e, especificamente, nos povos Timbira desses estados.

Ficou claro que a zona de intermedicalidade no caso dos povos Timbira envolve agentes com consciência sociomédica bastante distinta entre si e que há numerosos casos de conflitos que poderiam ser enumerados aqui. Todavia, esse não seria o foco ideal para uma análise que busca revelar que é possível uma articulação de sistemas médicos, embora os conflitos sejam o elemento mais evidente neste quadro. Se observarmos atentamente o modo como os povos indígenas estão se apropriando de questões externas (como o significado da epidemia de DST/Aids), internalizando-as e situando-as em seus próprios sistemas ontológicos e cosmológicos de mundo, veremos que há caminhos para seguir em direção ao entendimento, respeito e tolerância perante as suas distintas práticas de promoção da saúde. Sem dúvida que o primeiro passo seria construir espaços horizontais e participativos que norteiem as relações políticas interétnicas no Brasil. 


\section{Notas}

1 Em virtude do falecimento do autor, a versão final deste capítulo foi aprovada pelas organizadoras.

2 Considero o conceito de quase objeto formulado por Bruno Latour (1993) como um viés privilegiado para apreender a temática proposta. Esse conceito é um esforço intelectual do autor visando a abarcar fenômenos atuais, em que as clássicas dicotomias da análise social (natureza x cultura; indivíduo x sociedade; sujeito x coletividade) não se apresentam mais como instrumentos interessantes de análises. Os quase objetos, nesse sentido, não surgem da dialética entre esses polos, mas estão por dentro, em cima e em todos os seus lados; e, nas palavras de Latour (1993: 90), eles são "reais como a Natureza, narradas como o Discurso, coletivas como a Sociedade, existenciais como o ser...".

3 O conceito mehin era, até o início do século XX, utilizado como um sinônimo de humanidade/ sociabilidade dos povos Timbira, circunscrevendo-os em um espaço de significado. O seu antônimo - conceito cupen - era utilizado para designar outros povos indígenas não Timbira, assim como os diversos não indígenas que iam se estabelecendo no interior do Maranhão e do que hoje é Tocantins. Esse processo se alterou historicamente com a inserção dos Timbira em um sistema de atenção indigenista, assim como a fragmentação de seus territórios contribuiu para o processo de cristalização de etnicidade e a aceitação interna das diversas etnias (Krahô, Krikati, Gavião, Canela e Apinajé). Ver Nimuendaju (1971) para maior compreensão dos Timbira no sentido mais amplo; Roberto da Matta (1976) para os Apinajé; e William Crocker (2004) para os Canela.

4 Neste capítulo não irei entrar na análise sobre a relação entre atenção à saúde indígena e os Gavião Parakatejê pelas particularidades desse contexto, especialmente após o convênio desse povo indígena com a Companhia Vale do Rio Doce. Sobre os Krepynkatejê também não entrarei em detalhes, já que por muito tempo foram considerados um grupo Guajajara, especialmente pela ausência dos padrões que traçam o perfil dos povos Timbira. Em respeito aos aspectos históricos e ao novo direcionamento que os próprios Krepynkateyê estão procurando ao estabelecer com maior aproximação de outros povos Timbira, eles estão incorporados na presente análise.

5 O diagnóstico pode não ser hipermetropia, mas sim miopia de gestão. Essa é outra metáfora de problema oftalmológico, já que a miopia provoca dificuldade de enxergar objetos distantes. O paralelo consiste na versão de que para muitos as complexidades do tema da atenção à saúde indígena faz com que os povos indígenas e seus valores socioculturais estejam distantes dos gabinetes dos gestores, ainda mais em um contexto em que a Funasa não tinha a menor experiência nesse tema.

6 Há diferentes denominações para o que chamamos de pajés nos povos Timbira. Os Apinajé chamam de wayangá; os Krahô, de wajacá; os Krikati e Gavião Pyhcobjê, de hy-cahur; e os Apanjiekra-Canela e Ramkokamekra-Canela chamam de kaj, mas reconhecem também a nomenclatura de wayacá. Todos esses povos traduzem esses termos para o português como curador. 
7 "A melhoria do estado de saúde dos povos indígenas não ocorre pela simples transferência para eles de conhecimentos e tecnologias da biomedicina, considerando-os como receptores passivos, despossuídos de saberes e práticas ligadas ao processo saúde-doença. O reconhecimento da diversidade social e cultural dos povos indígenas, a consideração e o respeito dos seus sistemas tradicionais de saúde são imprescindíveis para a execução de ações e projetos de saúde e para a elaboração de propostas de prevenção/promoção e educação para a saúde adequadas ao contexto local" (Brasil, 2002).

8 Para essa região havia, na época da coleta de dados, seis casos de indígenas soropositivos.

9 A situação de HIV/Aids no entorno das terras indígenas dos povos Timbira do Maranhão e do Tocantins indica que nessas áreas existem casos notificados e acompanhados pelas coordenações estaduais de DST/Aids. É interessante notar que a infecção nesses casos se deu em maioria pelo contato sexual heterossexual, o que é um agravante preocupante, porque é justamente nessas situações em que está a maior vulnerabilidade dos povos Krikati, Gavião, Krahô, Apinajé, Apanjekra e Ramkokamekra.

10 Nos outros povos, já havia agentes indígenas de saúde do sexo feminino.

11 A admissão da possibilidade de transmissão de DST entre os próprios índios não exclui a possibilidade de que ela também ocorra por meio de contato interétnico.

12 Traduzo cahãexy dessa forma porque o sufixo xý representa a alteração. Por exemplo, dor de cabeça é $i$ kran xý (em que ikran é minha cabeça e xá o sufixo que indica que o estado dela foi alterado por alguma razão).

13 A grande maioria dos dados sobre essas imagens foi obtida pelos pesquisadores indígenas em suas entrevistas, nas quais eram orientados a não identificar os entrevistados, somente apontando sexo e idade. Na hora da tradução, cada pesquisador indígena traduzia as suas entrevistas em um local onde os outros não pudessem ouvir a voz nem reconhecer a autoria dos depoimentos, evitando assim a exposição dos entrevistados. A ênfase foi em pessoas jovens, e os assistentes explicavam antes o motivo de estarem fazendo tais entrevistas.

14 Os Apinajé tem um nome distinto para designar parente (Da Matta, 1976).

15 O sangue placentário também é considerado perigoso. Nas palestras e conversas no pátio da aldeia e na casa de wyty, era possível estabelecer ligações entre a transmissão sanguínea das DST e do HIV/Aids, assim como entre o sangue da placenta e a transmissão vertical da Aids. Os Timbira ficavam impressionados com os dados sobre crianças indígenas soropositivas por meio da transmissão materno-vertical.

16 Em tempos de política, principalmente nas eleições municipais, em que o voto indígena tem um peso considerável, há vários shows e comícios nas aldeias, sempre com muito forró e bebidas, o que também implica interações sexuais com não indígenas. 


\section{Referências}

ÁVILA, T. "Não É do Jeito Que Eles Quer, É do Jeito Que Nós Quer": os Krahô e a biodiversidade, 1988. Dissertação de Mestrado, Brasília: Programa de Pós-Graduação em Antropologia Social da Universidade de Brasília.

CROCKER, W. The Canela: kindship, ritual and sex in an Amazonian tribe. Belmont, CA: Wadsworth Pub Co, 2004.

BRASIL. Ministério da Saúde. Política Nacional de Atenção à Saúde dos Povos Indígenas, 2002. Disponível em: <http://bvsms.saude.gov.br/bvs/publicacoes/politica_saude_indigena.pdf>. Acesso em: jun. 2014.

DA MATTA, R. Um Mundo Dividido: a estrutura social dos Apinajé. Petrópolis: Vozes, 1976.

FOLLÉR, M.-L. Intermedicalidade: a zona de contato criada por povos indígenas e profissionais de saúde. In: LANGDON, E. J. G GARNELO, L. (Orgs.). Saúde dos Povos Indígenas: reflexões sobre antropologia participativa. Rio de Janeiro: Contracapa, ABA, 2004.

GREENE, S. The shamans needle: development, shamanic agency, and intermedicality. American Ethnologist, 25 (4): 634-658, 1998.

LATOUR, B. We Have Never Been Modern. Cambridge, Massachusetts: Harvard University Press, 1993.

MELATTI, J. C. O mito e o xamã. Revista do Museu Paulista, 14: 60-70, 1963.

MELATTI, J. C. Índios e Criadores: a situação dos Krahô na área pastoril do Tocantins, 1967. Monografia, Rio de Janeiro: Instituto de Ciências Sociais da Universidade Federal do Rio de Janeiro.

MELATTI, J. C. O Messianismo Krahô. São Paulo: Herder, Edusp, 1972.

MELATTI, J. C. Ritos de uma Tribo Timbira. São Paulo: Ática, 1978.

NIMUENDAJU, C. The Eastern Timbira. v. XLI. Berkeley, Los Angeles: University of California Press, 1971 [1946].

RAMOS, A. Indigenism: etnhic politics in Brazil. Madison, Wisconsin: The University of Wisconsin Press, 1998. 
Formato: $21 \times 26 \mathrm{~cm}$

Tipologia: Baskerville Win95BT

Papel: offset $90 \mathrm{~g} / \mathrm{m}^{2}$ (miolo) e Cartão Supremo $250 \mathrm{~g} / \mathrm{m}^{2}$ (capa)

CTP, impressão e acabamento: Imo's Gráfica e Editora Ltda.

Rio de Janeiro, novembro de 2014.

Não encontrando nossos títulos em livrarias, contactar a EDITORA FIOCRUZ:

Av. Brasil, 4036 - térreo - sala 112 - Manguinhos

21040-361 - Rio de Janeiro - RJ

Tel.: (21) 3882-9039 e 3882-9007

Telefax: (21) 3882-9006 editora@fiocruz.br

www.fiocruz.br/editora 